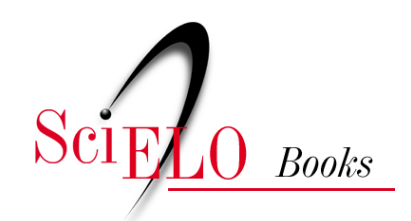

\title{
Diálogos sobre a religião natural
}

\author{
David Hume \\ Bruna Frascolla (transl.)
}

HUME, D. FRASCOLLA, R., transl. Diálogos sobre a religião natural [online]. Salvador: EDUFBA, 2016, 263 p. ISBN: 978-85-232-1867-6. https://doi.org/10.7476/9788523218676.

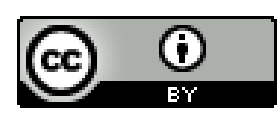

All the contents of this work, except where otherwise noted, is licensed under a Creative Commons Attribution $\underline{4.0 \text { International license. }}$

Todo o conteúdo deste trabalho, exceto quando houver ressalva, é publicado sob a licença Creative Commons Atribição 4.0.

Todo el contenido de esta obra, excepto donde se indique lo contrario, está bajo licencia de la licencia Creative Commons Reconocimento 4.0. 
Biálog̣os solure a ralígiãa natural 
UNIVERSIDADE FEDERAL DA BAHIA

Reitor

João Carlos Salles Pires da Silva

Vice-reitor

Paulo César Miguez de Oliveira

Assessor do Reitor

Paulo Costa Lima

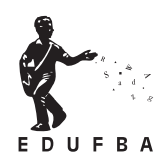

EDITORA DA UNIVERSIDADE FEDERAL DA BAHIA

Diretora

Flávia Goulart Mota Garcia Rosa

Conselho Editorial

Alberto Brum Novaes

Angelo Szaniecki Perret Serpa

Caiuby Alves da Costa

Charbel Niño El Hani

Cleise Furtado Mendes

Dante Eustachio Lucchesi Ramacciotti

Evelina de Carvalho Sá Hoisel

José Teixeira Cavalcante Filho

Maria Vidal de Negreiros Camargo 


\title{
DAVID HUME
}

\section{Bíálog̣os solure a relígíão natural}

\author{
Tradução, notas e posfácio de \\ BRUNA FRASCOLLA
}

Inclui seleção de cartas de Hume feitas à época de sua revisão da obra, além de fragmentos inéditos em português.

Salvador

EDUFBA

2016 
2016, Bruna Frascolla.

Direitos dessa edição cedidos à Edufba.

Feito o Depósito Legal

Grafia atualizada conforme o Acordo Ortográfico da Língua Portuguesa de 1990, em vigor no Brasil desde 2009.

\section{Capa e Projeto Gráfico}

Leonardo Mota Lorenzo

Imagem da Capa

Sandro Botticelli - A primavera

Revisão e Normalização

\section{Equipe da EDUFBA}

\section{Sistema de Bibliotecas - UFBA}

Hume, David, 1711-1776.

Diálogos sobre a religião natural / David Hume ; tradução, notas e posfácio de Bruna Frascolla. - Salvador : EDUFBA, 2016.

$$
262 \mathrm{p} \text {. }
$$

"Inclui seleção de cartas de Hume feitas à época de sua revisão da obra, além de fragmentos inéditos em português."

Inclui bibliografia.

ISBN 978-85-232-1499-9

1. Teologia natural. 2. Religião - Filosofia. 3. Filosofia da natureza. 4. Filosofia escocesa. I. Frascolla, Bruna. II. Título.

Editora afiliada à
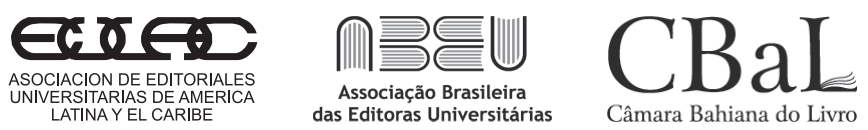

\section{Editora da UFBA}

Rua Barão de Jeremoabo, s/n - Campus de Ondina

40170-115 - Salvador - Bahia

Tel.: +55 71 3283-6164

Fax: +55 $713283-6160$

www.edufba.ufba.br

edufba@ufba.br 


\section{Nota prévia concernente a esta edição}

Os Diálogos sobre a religião natural tiveram uma longa história antes da publicação. Esta se deu somente três anos após a morte de Hume, como o desculpável cumprimento de sua última vontade, providenciada pelo sobrinho. Na capa, como que a indicar falta de comprometimento com o livro herético, não havia sequer o nome do editor.

Ao contrário de como soem ser obras póstumas - encontradas em gavetas, mal-acabadas ou desprezadas pelo autor -, os Diálogos foram-no pela deliberação do próprio Hume: por tratarem de tema que gerava grande antipatia social, ele os manteve na gaveta por anos a fio. Assim, por anos a fio tiveram revisões cuidadosas.

Acompanhando certas cartas de Hume, é possível formar uma ideia do histórico redatorial dos Diálogos. Aliando-as ao exame do manuscrito, onde se podem notar rasuras, inserções e variações na caligrafia, Norman Kemp Smith fez sua consagrada edi- 
ção ${ }^{1}$ desta obra apontando alterações no texto, e por isto tal foi a edição usada como base para a presente tradução dos Diálogos. Pelo que ele pôde concluir, houve um período mais continuado de revisão, de 1751 a 1763, e uma revisão final em 1776, ano da morte de Hume. Seguindo estas informações, indiquei neste volume as alterações mais extensas ou significativas feitas por Hume, bem como o pertencimento a qual período de revisão. $\mathrm{O}$ leitor que quiser conferir todas as alterações terá, além da edição Kemp Smith, o próprio manuscrito dos Diálogos disponível em www.davidhume.org. Já o início da redação é difícil precisar, pois, como se verá na carta II deste volume, Hume queimara um texto com raciocínios similares escrito ainda antes de completar 20 anos, i.e., antes de 1731 .

Neste volume constam cartas desses dois períodos de revisão textual (i.e., 1751-63 e 1776) onde Hume aluda aos Diálogos ou a discussões teológicas. Em especial nas últimas - inclusive a derradeira -, o leitor acompanhará os atribulados planos de Hume para garantir que seu livro fosse mesmo publicado quando ele morresse.

Por fim, dada a irregularidade da tradução dos nomes próprios desta obra na literatura, esclareço que segui as regras para a versão de nomes próprios do grego, passando para o latim e em seguida para o português. Nisto contei com a ajuda do Prof. Júlio Lopes Rego, a quem agradeço.

1 Eis a referência: HUME, David. Dialogues concerning Natural Religion. 2. ed. Nova Iorque: Macmillan, 1987. 


\section{Abreviações}

Para Hume, usei as abreviações de praxe, que põem em caixa alta as primeiras letras dos títulos anglófonos. Os algarismos que se seguem à abreviação são perfeitamente identificáveis para qualquer leitor que tenha qualquer edição em mãos - são seções, partes ou capítulos. O símbolo § indica o parágrafo, o que também possibilita ao leitor encontrar os trechos em qualquer edição. As obras clássicas têm sempre fragmentos numerados, e é a eles que aludo.

DNR HUME, D. Diálogos sobre a religião natural. Neste volume.

NHR HUME, D. História natural da religião. Tradução de Jaimir Conte. São Paulo: UNESP, 2005. 158p.

EHU HUME, D. Investigação sobre o entendimento humano. Lisboa: Casa da Moeda, 2002. 178p. Tradutor: João Paulo Monteiro.

THN HUME, D. Tratado da natureza humana. 2. ed. São Paulo: UNESP, 2009. 759p. Tradutora: Déborah Danowski. 
A HUME, D. Resumo de um tratado da natureza humana. Tradução Rachel Gutiérrez e José Sotero Caio. Florianópolis: Paraula, 1995. 125p.

L HUME, D. The letters of David Hume. Oxford: Oxford University Press, 2011. 2v.

NL HUME, D. New Letters of David Hume. Oxford: Oxford University Press, 2011.251p.

Ac CÍCERO, M. TúlioT.. Academica. In: CÍCERO, M. T. De natura deorum; Academica. Tradução de H. Rachkam. Michigan: Harvard University Press, 2005. 664p. Bilíngue.

ND CÍCERO, M. T. De natura deorum; Academica. Tradução de H. Rachkam. Michigan: Harvard University Press, 2005. 664p. Bilíngue.

RN LUCRÉCIO, Tito. Da natureza [De rerum natura]. In: EPICURO, LUCRÉCIO, CÍCERO et al. Os Pensadores. Tradução de Agostinho da Silva. São Paulo: Abril Cultural, 1973. 329p. v. 5. 


\section{Sumário}

\section{Diálogos sobre a religião natural}

\section{3 - Pânfilo a Hermipo}

\section{7 - Parte I}

[Cleantes ataca o ceticismo pirrônico - Filão professa o ceticismo acadêmico - Narrativa da história do ceticismo - Explicação histórica e política das posições filosóficas de Dêmeas e Cleantes.]

\section{1 - Parte II}

[A tese de Dêmeas da incognoscibilidade da natureza divina - A tese de Cleantes - Críticas de Filão à analogia de Cleantes: Os objetos são desproporcionais e falta experiência - Filão introduz a discussão do sentido: "Não sei o que é Deus."]

\section{5 - Parte III}

[Ilustrações de Cleantes - Crítica de Dêmeas ao seu antropomorfismo feita com base na teoria humeana das ideias.]

\section{3 - Parte IV}

[Crítica de Cleantes ao misticismo de Dêmeas feita com base numa discussão do seu sentido - Crítica de Filão a Cleantes: Não há por que determinar que a ordem natural tem que advir da racional Discussão do sentido: Nomes podem ser usados para ocultar a ignorância.]

\section{3 - Parte V}

[Filão aponta uma série de non sequitur no argumento de Cleantes - Reductio ad absurdum: Seguindo as regras de Cleantes, Filão inventa teologias esdrúxulas.] 


\section{1 - Parte VI}

[A teologia estoica, baseada na mesma argumentação de Cleantes, está mais de acordo com a analogia pretendida pelo teísta - Preâmbulo da hipótese de seleção natural.]

\section{9 - Parte VII}

[Teologias inventadas por Filão em conformidade com as premissas de Cleantes apontam a arbitrariedade das conclusões teístas - Há experiência de a razão advir da geração, mas não o contrário: o sistema pagão é mais provável - Ataque à evidência do desígnio: tais teologias, hoje esdrúxulas, eram praxe nos sistemas pagãos.]

\section{7 - Parte VIII}

[Filão ressuscita o epicurismo e formula uma hipótese de seleção natural.]

\section{5 - Parte IX}

[Dêmeas demonstra a existência de Deus - Crítica humeana de Cleantes a essa prova: Não se podem demonstra questões de fato - Filão critica Cleantes com sua hipótese de seleção natural - Consenso: como o argumento a priori não convence o vulgo, então o sentimento religioso advém doutras fontes.]

\section{1 - Parte X}

[Cleantes e Dêmeas se atacam mutuamente: Enquanto este afirma a infelicidade geral e deriva disto o sentimento religioso, o outro tem que garantir a felicidade geral para poder afirmar a bondade ou sabedoria divina - Ressuscitando o trilema de Epicuro, Filão critica o antropomorfismo de Cleantes. - Apologia do ceticismo.]

\section{5 - Parte XI}

[Dado o antropomorfismo assumido por Cleantes, Filão mostra como Deus poderia ter feito um melhor trabalho ao criar um mundo propenso à nossa felicidade: a inferência da bondade divina não se sustenta - O que se deve inferir dos fenômenos é que, se há uma deidade que os presida, ela amoral - Ao afirmar uma característica da deidade (que deveria ser incognoscível) e ao perguntar pela causa do mal, Filão ataca Dêmeas - A explicação histórica e política para as posições dos adversários se repete.] 


\section{9 - Parte XII}

[Filão debocha de Cleantes e finge concordar com ele - Discussão do sentido - Os efeitos da religião são perniciosos - Discussão verbal torna possível que se assinta a uma analogia sem significado.]

\section{Cartas selecionadas}

I. Carta a Gilbert Elliot de Minto - 149

Petição dos sacristãos - 155

II. Carta a Gilbert Elliot de Minto - 159

III. Carta ao autor de The Delineation of the Nature and Obligation of Morality - 165

IV. Carta a Adam Smith - 169

V. Carta a Gilbert Elliot de Minto - 175

VI. Carta a Adam Smth - 179

VII. Carta a Adam Smith - 181

VIII. Carta a William Strahan - 183

IX. Carta a Adam Smith - 187

X. Carta a Adam Smith - 189

\section{1 - Posfácio}

261 - Referências 


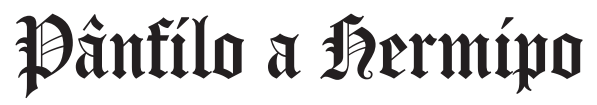 \&}

1. Tem-se notado, meu Hermipo, que embora os filósofos antigos exprimissem a maior parte de sua instrução na forma de diálogo, este método de composição vem sendo pouco praticado em eras mais tardias e tem raramente tido êxito nas mãos daqueles que o tentam. $\mathrm{O}$ argumento acurado e regular, de fato, tal como se espera agora de investigadores filosóficos, lança naturalmente qualquer homem à maneira metódica e didática, na qual pode, sem preparação, explicar o ponto pretendido e proceder assim, sem interrupção, para deduzir as provas sobre as quais tal ponto se estabelece. Proferir um SISTEMA em conversação dificilmente parece natural, e enquanto o escritor de diálogo deseja, ao apartar-se do estilo direto de composição, dar um ar mais livre à sua performance e evitar a aparência de autor e leitor, sujeitase a cair numa inconveniência pior e dar imagem de pedagogo e pupilo. Ou, se continuar a disputa no espírito natural da boa 
companhia, lançando numa variedade de tópicos e preservando um equilíbrio próprio entre os falantes, muitas vezes perde tanto tempo com preparações e transições que o leitor dificilmente achará que ele próprio foi recompensado por todas as graças do diálogo por causa da ordem, brevidade e precisão que lhe são sacrificadas.

2. Há alguns assuntos, no entanto, para os quais a escrita de diálogo é peculiarmente adequada, e nos quais é ainda preferível ao método de composição direto e simples.

3. Qualquer ponto de doutrina que seja tão óbvio que dificilmente admita disputa, mas ao mesmo tempo tão importante que seja impossível de inculcar-se com frequência excessiva, parece requerer algum método de lidar consigo onde a novidade do estilo possa compensar a trivialidade do assunto, a vivacidade da conversação possa reforçar o preceito, e a variedade de luzes apresentada por várias personagens e caracteres possa não parecer nem tediosa, nem redundante.

4. Qualquer questão de filosofia, por outro lado, que seja tão obscura e incerta que a razão humana não possa encontrar nenhuma determinação fixa no que lhe diz respeito, se deve ser tratada mesmo, parece levar-nos naturalmente ao estilo de diálogo e conversação. A homens razoáveis pode ser permitido diferir onde ninguém consegue com razoabilidade ser positivo: opiniões opostas, mesmo sem qualquer decisão, proporcionam um entretenimento agradável; e, se o assunto for curioso e interessante, o livro nos conduz dalguma maneira à companhia e une os dois mais grandiosos e puros prazeres da vida humana: estudo e sociedade.

5. Felizmente, essas circunstâncias todas devem se encontrar no assunto da RELIGIÃo NATURAL. Que verdade é tão óbvia, tão certa quanto a existência dum Deus que as eras mais ignorantes reconheceram, para a qual os gênios mais refinados se empenharam ambiciosamente em produzir novas provas e argumentos? 
Que verdade é tão importante quanto esta, que é o fundamento de todas as nossas esperanças, a mais segura fundação da moralidade, o mais firme suporte da sociedade e o único princípio que deve nunca se ausentar de nossos pensamentos e meditações? Mas, ao tratar dessa verdade importante e óbvia, que questões obscuras ocorrem concernentes à natureza desse Ser divino, seus atributos, seus decretos, seu plano de providência? Estas têm estado sempre sujeitas às disputas dos homens: acerca destas, a razão humana não alcançou nenhuma determinação certa. Mas estes são tópicos tão interessantes que não podemos restringir nossa investigação incansável no que lhes diz respeito; embora nada, senão dúvida, incerteza e contradição tenham, como ainda têm, sido o resultado de nossas pesquisas mais acuradas.

6. Isto eu tive recentemente ocasião de observar enquanto passei, como de costume, parte do verão com ClEANTES e estive presente a essas conversações dele com FILÃO e DÊMEAS, das quais te dei dia desses certa descrição imperfeita. Tua curiosidade, contaste-me então, estava tão excitada que tenho necessariamente de entrar num detalhe mais exato de seus raciocínios e expor aqueles vários sistemas que desenvolveram a respeito de tão delicado assunto como o da religião natural. $\mathrm{O}$ contraste notável entre seus caracteres elevou ainda mais tuas expectativas enquanto opuseste o espírito filosófico acurado de CLEANTES ao ceticismo descuidado de FILÃo, ou comparaste quaisquer das suas disposições à rígida e inflexível ortodoxia de DÊMEAS. Minha juventude me tornou um mero auditor de suas disputas, e a curiosidade natural às primeiras estações da vida imprimiu tão profundamente em minha memória toda a cadeia e conexão de seus argumentos que, espero, não hei de omitir nem confundir qualquer parte considerável deles nesta exposição. 


\section{Parte I}

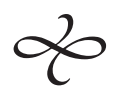

1. Depois que me juntei à companhia que encontrei sentada na biblioteca de Cleantes, Dêmeas fez a Cleantes alguns cumprimentos pelo grande cuidado que ele tomou em minha educação e por sua perseverança e constância incansáveis em todas as suas amizades. "O pai de PÂNFILO", disse ele, "era teu amigo íntimo; o filho é teu pupilo, e pode de fato ser considerado teu filho adotivo, se julgarmos pelos cuidados que dispensas em fornecerlhe todo ramo útil de literatura e ciência. Não és menos faltoso, estou persuadido, de prudência do que de indústria. Portanto, comunicar-te-ei uma máxima que tenho observado no que diz respeito às minhas próprias crianças, pois posso assim me inteirar do quanto ela concorda com tua prática. $\mathrm{O}$ método que sigo em sua educação se funda nos dizeres de um antigo, que 'estudantes de filosofia têm primeiro que aprender lógica, então ética, 
a seguir física, por último a natureza dos deuses ${ }^{*}$. Essa ciência da teologia natural, de acordo com ele, sendo a mais abstrusa e profunda de todas, demandou o mais maduro juízo de seus estudantes, e a ninguém, senão uma mente enriquecida com todas as outras ciências, pode com segurança ser confiada."

2. "Estás tão atrasado", diz FILÃo, "em ensinar às tuas crianças os princípios da religião? Não há perigo de elas negligenciarem completamente aquelas opiniões das quais ouviram tão pouco durante todo o curso de sua educação?" "É apenas enquanto uma ciência", replicou DÊMEAS, "sujeita ao raciocínio humano e disputa, que eu adio o estudo de teologia natural. Temperar suas mentes com piedade precoce é o meu cuidado principal; e por preceito e instrução contínuos, e espero também que por exemplo, gravo profundamente em suas mentes macias uma reverência habitual a todos os princípios da religião. Enquanto elas atravessam todas as outras ciências, aponto ainda a incerteza de cada parte, as eternas disputas dos homens, a obscuridade de toda filosofia e as conclusões estranhas, ridículas, que alguns dos maiores gênios derivaram de seus princípios da mera razão humana. Tendo assim domado suas mentes para uma submissão apropriada e autodesconfiança, não tenho mais escrúpulos em abrir para elas os maiores mistérios da religião, e tampouco receio qualquer perigo advindo dessa arrogância presunçosa da filosofia que possa levá-las a rejeitar as mais estabelecidas doutrinas e opiniões."

3. "Tua precaução", diz FILÃo, "em temperar as mentes de tuas crianças com piedade precoce é decerto muito razoável, e não mais do que é necessária nesta era profana e irreligiosa. Mas o que admiro principalmente em teu plano de educação é teu método de tirar vantagem dos verdadeiros princípios de filosofia e aprendizado que, inspirando orgulho e autossuficiência, têm

* Crisipo apud Plut. de repug. Stoicorum. [As notas de Hume estarão sempre com asterisco] 
em todas as eras se achado tão destrutivos para os princípios de religião. De fato os homens vulgares que, podemos notar, são estranhos a ciência e investigação profunda, ao observarem as disputas sem fim dos eruditos, têm comumente um rematado desdém pela filosofia e fixam-se mais rápido, desse modo, nos grandes pontos de teologia que lhes foram ensinados. Aqueles que adentram um pouco em estudo e investigação, ao encontrarem muitas aparências de evidência nas doutrinas mais novas e mais extraordinárias, pensam que nada é difícil demais para a razão humana; e, arrombando pretensiosamente todas as cercas, profanam os mais recônditos santuários do templo. Mas CLEANTES, espero, concordará comigo que, depois de termos abandonado a ignorância, que é o remédio mais seguro, resta ainda outro expediente para prevenir essa liberdade profana. Que os princípios de DêMEAS sejam aprimorados e cultivados: tornemonos completamente cônscios da fraqueza, da cegueira e dos limites estreitos da razão humana; consideremos devidamente sua incerteza e suas contrariedades infindáveis mesmo nos assuntos de vida comum e prática; coloquem-se à nossa frente erros e ilusões de nossos próprios sentidos, as dificuldades insuperáveis que acompanham os primeiros princípios de todo sistema, as contradições que aderem às próprias ideias de matéria, causa e efeito, extensão, espaço, tempo, movimento e, numa palavra, quantidade de todo tipo, que é o objeto da única ciência que pode com justeza pretender alguma certeza e evidência. Se esses tópicos forem expostos em sua luz plena, como o são por alguns filósofos e quase todos os teólogos, quem poderá reter tal confiança nessa frágil faculdade da razão a ponto de ter alguma estima por suas determinações em pontos tão sublimes, tão abstrusos, tão remotamente distantes da vida comum e da experiência? Se a aderência mútua ${ }^{2}$ das partes duma pedra ou mesmo

2 Em inglês, coherence, normalmente vertido por "coerência", que não faz sentido. Podem-se encontrar alguns latinismos no texto de Hume, e um dos sen- 
a composição das partes que a tornam extensa; se esses objetos familiares, digo eu, são tão inexplicáveis e contêm circunstâncias tão irreconciliáveis e contraditórias, com que segurança poderemos decidir a respeito da origem de mundos, ou remontar à sua história de eternidade a eternidade?"

4. Enquanto FILÃo pronunciava estas palavras, eu pude observar um sorriso nos semblantes tanto de DêMEAS quanto de CLEANTES. O de DÊMEAS parecia implicar uma satisfação sem reservas com as doutrinas proferidas - mas nas feições de ClEANTES pude distinguir um ar de astúcia, como percebesse alguma zombaria ou malícia artificiosa nos raciocínios de FILÃO.

5. "Propões então, Filão," disse Cleantes, "erigir fé religiosa sobre ceticismo filosófico, e pensas que, se a certeza e a evidência forem expulsas de todo outro assunto de investigação, retirarse-ão por inteiro para essas doutrinas teológicas e lá adquirirão uma força superior e autoridade. Se teu ceticismo for tão absoluto e sincero quanto pretendes, descobri-lo-emos daqui a pouco, quando nossa companhia se cessar: veremos então se sais pela porta ou pela janela, e se duvidas mesmo de que teu corpo tem gravidade ou pode sofrer injúrias pela queda, de acordo com a opinião popular derivada de nossos falazes sentidos e falacíssima experiência. E essa consideração, DÊMEAS, pode muito bem, penso eu, servir para abater nossa má vontade para com essa seita humorística dos céticos. Se eles estiverem completamente a sério, não perturbarão o mundo por muito tempo com suas dúvidas, cavilações e disputas; se estiverem apenas de brincadeira, serão talvez maus zombeteiros, mas não poderão nunca ser muito perigosos, quer para o Estado, para a filosofia ou para a religião.

tidos de cohæreo é aderir. Ademais, observe-se que em certo momento Cícero fala de a "materia ipsa cohærere" (Ac., I, 24), que Rackham, em sua tradução da coleção Loeb, verteu por "form a concrete whole" (formar um conjunto concreto). 
6. "Na realidade, FILÃO," continuou ele, "parece certo que embora um homem, numa descarga de humor depois de intensa reflexão sobre as muitas contradições e imperfeições da razão humana, possa renunciar inteiramente a toda crença e opinião, é impossível para ele perseverar nesse ceticismo total ou fazê-lo aparecer em sua conduta por umas poucas horas. Objetos externos o pressionam, paixões o solicitam: sua melancolia filosófica se dissipa, e mesmo a violência mais extrema sobre sua índole não será capaz, durante algum tempo, de preservar a pobre aparência de ceticismo. E por que razão impor a si próprio tal violência? Este é um ponto em que lhe será impossível satisfazer a si próprio de maneira consistente com os seus princípios céticos; então, pelo conjunto, nada pode ser mais ridículo do que os princípios dos antigos PIRRÔNICOS, se eles realmente tentaram, como se pretende, prolongar o mesmo ceticismo que aprenderam pelas declamações de sua escola e que devem ter confinado a ela.

7. “Neste aspecto, surge uma grande semelhança entre a seita dos ESTOICOS e a dos PIRRÔNICOS, embora sejam antagonistas perpétuos: ambos parecem fundados nessa máxima errônea de que o que um homem pode executar algumas vezes e em algumas disposições, ele pode executar sempre e em qualquer disposição. Quando a mente, por reflexões estoicas, é elevada a um sublime entusiasmo de virtude e é fortemente atingida por alguma espé$\mathrm{cie}^{3}$ de honra ou bem público, a dor e o sofrimento físico mais extremos não prevalecerão sobre tal senso elevado de dever; e é possível, talvez, por meio disso, até sorrir e exultar em meio a torturas. Se esse algumas vezes pode ser o caso em fato e realidade, pode muito mais um filósofo, em sua escola ou até em seu gabinete, estimular-se a si próprio para um tal entusiasmo

3 Como Hume marca de maneira igual palavras latinas, ênfases e citações, é possível que, ao invés de "espécie" em inglês, aqui se trate de species, a tradução latina do termo grego i $\delta \varepsilon ́ \alpha$ (cf. Ac. I, 30). Talvez faça mais sentido que o estoico não se arrebate com algum determinado tipo de bem, mas com a ideia ou representação do bem. 
e suportar em imaginação a dor mais aguda ou o evento mais calamitoso que lhe seja possível conceber. Mas como poderá suportar esse próprio entusiasmo? $\mathrm{O}$ pendor de sua mente relaxa e não pode ser chamado de volta para o prazer: distrações o extraviam, infortúnios o atacam inesperadamente, e o filósofo afunda gradualmente até o plebeu."

8. "Admito a tua comparação entre os ESTOICOS e os CÉTICOs", replicou Filão. "Mas podes ao mesmo tempo observar que embora a mente não seja capaz, no estoicismo, suportar os voos mais altos da filosofia, ainda continua a reter algo de sua disposição anterior mesmo quando ela se aprofunda mais - e os efeitos do raciocínio estoico aparecerão em sua conduta na vida comum e através de todo o teor de suas ações. As antigas escolas, particularmente aquela de ZENÃO, produziram exemplos de virtude e constância que parecem espantosos aos tempos presentes.

Falsa filosofia, estéril ciência,

Contudo esses precitos miserandos

Conseguem por magia deleitosa

Algum tempo abrandar a dor, a angústia;

Embalam-se em falazes esperanças

E, como de aço tríplice, guarnecem

De inflexível paciência os peitos duros. ${ }^{4}$

Numa maneira semelhante, se um homem se acostumou a considerações céticas sobre a incerteza e os limites estreitos da razão, não as esquecerá inteiramente quando voltar suas reflexões para outros assuntos, mas em todos os seus princípios filosóficos e raciocínios, não ouso dizer em sua conduta comum, será tido por diferente daqueles que não formaram opinião alguma sobre o caso ou que entretiveram opiniões mais favoráveis à razão humana.

4 Kemp Smith nos informa tratar-se duma citação de Paradise Lost, II, de Milton. Usei a versão de Antônio José de Lima Leitão (1787-1856), disponível em www.ebooksbrasil.org. 
9. “Para qualquer extensão que qualquer homem possa levar seus princípios especulativos de ceticismo, ele terá que agir, reconheço, e viver e conversar como os outros, e para essa conduta não é obrigado a dar qualquer outra razão que não a absoluta necessidade sob a qual jaz de fazê-lo assim. Se ele alguma vez leva suas especulações para mais longe do que essa necessidade o força, e filosofa quer sobre assuntos morais, quer naturais, é seduzido por certo prazer e satisfação que encontra em se empregar dessa maneira. Ele considera ainda que todos, mesmo na vida comum, são forçados a ter mais ou menos essa filosofia; que desde a nossa mais precoce infância fazemos avanços contínuos ao formarmos princípios mais gerais de conduta e raciocínio; que quanto mais larga a experiência que adquirimos e mais forte a razão da qual somos dotados, sempre tornaremos nossos princípios mais gerais e compreensivos - e isso que chamamos de 'filosofia' não é nada senão uma operação mais regular e metódica do mesmo tipo. Filosofar sobre tais assuntos não é nada essencialmente diferente de raciocinar sobre a vida comum, e podemos apenas esperar maior estabilidade, se não maior verdade, de nossa filosofia na descrição de seu método de procedimento mais exato e escrupuloso.

10. "Mas quando olhamos além das questões humanas e as propriedades dos corpos ao redor, quando carregamos nossas especulações para ambas as eternidades, antes e depois do estado de coisas presente - para criação e formação do universo, a existência e propriedades de espíritos, os poderes e operações dum espírito universal existente sem início e sem fim, onipotente, onisciente, imutável, infinito e incompreensível -, precisamos estar bem afastados até da mais ínfima tendência de ceticismo para não ficarmos apreensivos por termos ido muito além do alcance de nossas faculdades. Enquanto confinamos nossas especulações a negócios, moral, política ou crítica, apelamos a todo momento ao senso comum e à experiência, que fortalecem 
nossas conclusões filosóficas e removem (ao menos em parte) a suspeita que tão justamente entretemos com relação a todo raciocínio que é muito sutil e refinado. Mas em raciocínios teológicos não temos essa vantagem, enquanto ao mesmo tempo estamos ocupados com objetos que, temos de estar cônscios, são grandes demais para o nosso alcance e, de todos os outros, são os que mais requerem que estejam familiarizados à nossa apreensão. Somos como forasteiros num país estranho, aos quais tudo tem de parecer suspeito e que estão em perigo a cada momento de transgredir as leis e costumes do povo com o qual eles vivem e conversam. Não sabemos até onde podemos confiar em nossos métodos vulgares de raciocínio em tal assunto, uma vez que, mesmo na vida comum e naquela província que lhes é peculiarmente apropriada, não podemos descrevê-los e somos guiados por um tipo de instinto ou necessidade ao empregá-los.

11. "Todos os céticos pretendem que, se a razão for considerada num aspecto abstrato, fornece argumentos invencíveis contra si própria; e que não poderíamos reter jamais qualquer convicção e segurança sobre qualquer assunto, não fossem os raciocínios céticos tão refinados e sutis que não são capazes de contrapor-se aos argumentos mais sólidos e naturais derivados dos sentidos e da experiência. Mas é evidente, sempre que nossos argumentos perdem essa vantagem e corremos para longe da vida comum, que o mais refinado ceticismo passa a estar em pé de igualdade com eles e é capaz de se lhes opor e contrabalancear. Um não tem mais peso do que o outro. A mente tem que permanecer em suspense entre ambos, e é bem nesse suspense ou balanço que está o triunfo do ceticismo."

12. "Mas observo", diz Cleantes, "a teu respeito, Filão, e de todos os céticos especulativos, que vossa doutrina e prática variam tanto nos pontos mais abstrusos de teoria quanto na conduta da vida comum. Sempre que uma evidência se desvela, aderis-lhe malgrado vosso pretenso ceticismo; e posso observar também 
alguns de vossa seita serem tão decisivos quanto aqueles que fazem as maiores profissões de certeza e segurança. Na realidade, não pareceria ridículo um homem que pretendesse rejeitar a explicação de NEWTON para os maravilhosos fenômenos do arco-íris porque essa explicação dá uma anatomia minuciosa dos raios de luz, um assunto de fato refinado demais para a compreensão humana? E o que dirias a alguém que, nada tendo em particular para objetar aos argumentos de Copérnico e GALILEU para o movimento da terra, houvesse de recusar seu assentimento, fundando-se nesse princípio geral de que tais assuntos são magníficos e remotos demais para serem explicados pela estreita e falaz razão do gênero humano?

13. "Há de fato um tipo de ceticismo bruto e ignorante, como bem observaste, que dá aos homens vulgares um preconceito contra aquilo que eles não entendem facilmente e os faz rejeitar todo princípio que requer raciocínio elaborado para ser provado e estabelecido. Esta espécie de ceticismo é fatal para o conhecimento; não para a religião, porquanto vemos que aqueles que fazem a sua maior profissão dão frequentemente seus assentimentos não apenas às grandes verdades do teísmo e da teologia natural, mas mesmo aos preceitos mais absurdos que certa superstição ${ }^{5}$ tradicional lhes recomendou. Creem firmemente em bruxas, embora não creiam ou escutem a mais simples proposição de EuCLIDES. Mas os céticos refinados e filosóficos caem numa inconsistência de natureza oposta. Levam suas investigações para os cantos mais abstrusos da ciência, e seu assentimento os acompanha a cada passo, proporcionado à evidência que encontram. São obrigados até mesmo a reconhecer que os objetos mais abstrusos

5 O uso intercambiável que Hume muitas vezes faz de religion e superstition também não deixa de ser latinismo: No latim clássico, religio e superstitio são sinônimos. 
e remotos são os que se explicam melhor pela filosofia ${ }^{6}$. A luz está na realidade anatomizada; o verdadeiro sistema dos corpos celestes está descoberto e averiguado. Mas a nutrição dos corpos por comida está ainda um mistério inexplicável; a aderência mútua das partes da matéria está ainda incompreensível. Esses céticos, portanto, são obrigados em toda questão a considerar cada evidência particular à parte e a proporcionar seu assentimento ao grau preciso de evidência que ocorre. Esta é sua prática em todas as ciências naturais, matemáticas, morais e políticas. E por que não a mesma, pergunto, na teológica e religiosa? Por que devem as conclusões apenas dessa natureza ser rejeitadas sob a presunção geral da insuficiência da razão humana sem qualquer discussão particular da evidência? Não é tal conduta desigual uma prova clara de preconceito e paixão?

14. "Nossos sentidos, dizes, são falazes; nosso entendimento, errôneo; nossas ideias, mesmo dos objetos mais familiares, extensão, duração, movimento, cheias de absurdos e contradições. Desafias-me a dissolver as dificuldades ou reconciliar as incompatibilidades que descobres nelas. Não tenho capacidade para tal empreendimento, não tenho ociosidade para isso, percebo que isso é supérfluo. Tua própria conduta em toda circunstância refuta teus princípios e mostra a mais firme confiança em todas as máximas recebidas da ciência, moral, prudência e comportamento.

15. "Jamais hei de assentir a uma opinião tão severa como aquela dum célebre escritor ${ }^{*}$ que diz que os céticos não são uma seita de filósofos, são uma seita de mentirosos. Eu posso, no entanto, afirmar (espero que sem ofensa) que eles são uma seita de

6 Aqui vale lembrar que a física à época era um ramo da filosofia, a filosofia natural.

* L'art de penser. [A passagem aludida está no décimo primeiro parágrafo do "Premier Discours» de La logique ou l'art de penser, de Antoine Arnauld e Pierre Nicole.] 
bufões ou zombeteiros. Mas por minha parte, sempre que me acho disposto a alegria e divertimento, devo certamente escolher meu entretenimento de uma natureza menos estupefaciente e abstrusa. Uma comédia, uma novela ou quando muito uma História, parece uma recreação mais natural do que tais sutilezas e abstrações metafísicas.

16. “Em vão o cético faria uma distinção entre ciência e vida comum ou entre uma ciência e outra. Os argumentos empregados em todas, se justos, são de uma natureza similar e contêm a mesma força e evidência. Ou, se houver uma diferença entre eles, a vantagem repousa inteiramente no lado da teologia e religião natural. Muitos princípios da mecânica são fundados em raciocínios bem abstrusos, ainda assim nenhum homem que tenha pretensões de ciência e mesmo nenhum cético especulativo pretende entreter a mais ínfima dúvida a seu respeito. $\mathrm{O}$ sistema COPERNICANO contém o paradoxo mais surpreendente e o mais contrário às nossas concepções naturais, às aparências e aos nossos próprios sentidos: até monges e inquisidores são agora obrigados a remover sua oposição a ele. E deveria FILÃo, um homem de gênio tão liberal e de conhecimento tão extenso, entreter quaisquer escrúpulos gerais indistintos a respeito da hipótese religiosa, que está fundada sobre os argumentos mais simples e óbvios e, a menos que encontre obstáculos artificiosos, tem tal acesso fácil e admissão na mente do homem?

17. "E aqui podemos observar", continuou ele voltando-se para DÊMEAS, "uma circunstância bem curiosa na história das ciências. Depois da união da filosofia à religião popular, sobre o primeiro estabelecimento da cristandade, nada era mais usual entre todos os professores religiosos do que declamações contra a razão, contra os sentidos e contra qualquer princípio derivado meramente de pesquisas e investigações humanas. Todos os tó- 
picos dos antigos acadêmicos ${ }^{7}$ foram adotados pelos Padres da Igreja e aí propagados para várias eras em toda escola e púlpito através da cristandade. Os Reformadores abraçaram os mesmos princípios de raciocínio, ou antes declamação, e todos os panegíricos sobre a excelência da fé foram seguramente interpolados com alguns ataques severos de sátiras contra a razão natural. Um célebre prelado também ${ }^{*}$, da comunhão romana, um homem do mais extenso estudo que escreveu uma demonstração do cristianismo, compôs ainda um tratado que contém as cavilações do PIRRONISMO mais audacioso e determinado. LOCKE parece ter sido o primeiro cristão que se aventurou a declarar abertamente que fé não é nada senão uma espécie de razão, que religião era apenas um ramo da filosofia e que uma cadeia de argumentos similar àquela que estabeleceu qualquer verdade em moral, política ou física foi sempre empregada ao descobrir todos os princípios de teologia natural e revelada. O mau uso que BAYLE e outros libertinos fizeram do ceticismo filosófico dos Padres da Igreja e dos primeiros Reformadores propagou ainda mais a judiciosa opinião do Sr. LOCKE - e é agora, de certo modo, reconhecido por todos os aspirantes ao raciocínio e à filosofia que ateu e cético são quase sinônimos. E é certo que homem algum está a sério quando professa este último princípio, e eu alegremente

$7 \quad$ No período ao qual Hume alude, inexistia a palavra latina scepticus, e ao invés disso se usava academicus. Usava-se esta expressão por os únicos textos céticos disponíveis serem os de Cícero, tendo Sexto Empírico sido redescoberto apenas em meados da Renascença. A popularização filosófica do termo se devesobretudo a Agostinho e Lactâncio, que argumentavam respectivamente contra os acadêmicos e baseado neles para assegurar a existência de Deus. Aqui, Hume alude à estratégia cética fideísta à moda de Lactâncio. Cf. o capítulo II de SCHMITT, Cicero Scepticus: A study of the influence of the Academica in the Renaissance. Martinus Nijhoff: Haia, 1972.

* Mons. Huet. [Kemp Smith informa que o texto aludido é o Traité philosophique de la faiblesse de l'esprit humain.] 
esperaria que houvesse poucos que seriamente professam aquele primeiro."

18. "Não te lembras", disse FiLÃo, "dos excelentes dizeres de Lorde BACON sobre isso?" "Que um pouco de filosofia" replicou Cleantes, "faz do homem ateu; um grande bocado converte-o à religião." "Esta é uma observação muito judiciosa também", disse FILÃo. "Mas o que tenho em vista é outra passagem, onde, tendo mencionado o tolo de DAVI que disse que em seu coração não havia nenhum Deus, esse grande filósofo observa que os ateus de hoje têm um quinhão duplo de tolice por, não contentes em dizerem que em seus corações não há nenhum Deus, também pronunciam essa impiedade com seus lábios e são, por isso, culpados de indiscrições e imprudências multiplicadas. Tais pessoas, embora estejam sempre tão a sério, não podem, creio eu, ser muito temíveis.

19. "Mas embora possas me considerar dentro dessa classe de tolos, não posso evitar comunicar uma observação que me ocorre da história do ceticismo religioso e irreligioso com a qual nos entretiveste. Parece-me que há sintomas fortes de padrismo em todo o progresso dessa questão. Durante eras ignorantes, tais como as que seguiram a dissolução das antigas escolas, os padres perceberam que ateísmo, deísmo ou heresia de qualquer tipo poderiam proceder apenas do questionamento presunçoso de opiniões recebidas e duma crença de que a razão humana era igual a tudo. A educação tinha então uma influência poderosa sobre as mentes dos homens e era quase igual em força àquelas sugestões dos sentidos e entendimento comum pelo qual o mais determinado cético deve permitir a si próprio ser governado. Mas no presente, quando a influência da educação diminuiu muito e os homens, por um comércio aberto com o mundo, aprenderam a comparar os princípios populares de nações e eras diferentes, nossos sagazes teólogos mudaram todo o seu sistema de filosofia e falaram a linguagem dos ESTOICOS, PLATÔNICOS e PERIPATÉTICOS, 
não aquela dos PIRRÔNICOS e ACADÊMICOS. Se desacreditarmos a razão humana, não teremos mais princípio algum para nos levar à religião. Assim, céticos numa era, dogmáticos noutra, qualquer que seja o sistema que melhor sirva ao propósito desses cavalheiros reverendos ${ }^{8}$ de dar-lhes uma ascendência sobre a humanidade, têm certeza de fazê-lo o seu sistema favorito e estabelecer o preceito."

20. "É muito natural", disse CleAnTES, "para os homens abraçar os princípios pelos quais eles podem melhor defender suas doutrinas e não têm que ter recurso a nenhum padrismo para dar conta de expediente tão razoável. E certamente nada pode conferir uma presunção mais forte de que uma série de princípios seja verdadeira e deva ser abraçada do que observar que ela tende à confirmação da verdadeira religião e serve para confundir as cavilações dos ateus, libertinos e livres-pensadores de toda denominação."

8 Em rasura feita entre 1751 e 1763 , "desses cavalheiros reverendos" substituiu "do clero". 


\section{円arte II}



1. "Devo admitir, Cleantes," disse Dêmeas, "que nada pode me surpreender mais do que a luz sob a qual puseste todo o tempo este argumento. Por todo o teor de teu discurso poder-se-ia imaginar que estivesses mantendo a existência de um Deus contra as cavilações de ateus e infiéis, e que te empenhasses em virar um paladino deste princípio fundamental da religião. Mas tal, espero, não é de modo algum uma questão entre nós. Nenhum homem, ou ao menos nenhum homem de senso comum, estou persuadido, jamais entreteve uma dúvida séria quanto a uma verdade tão certa e autoevidente. A questão não é concernente ao ser, mas à natureza de Deus. Esta eu afirmo, a partir das fragilidades do entendimento humano, ser ao mesmo tempo incompreensível e desconhecida para nós. A essência dessa mente suprema, seus atributos, a maneira de sua existência, a verdadeira natureza de sua duração - estes, e todo particular referente a um Ser tão 
divino, são misteriosos para o homem. Criaturas finitas, fracas e cegas, devemos nos humilhar perante sua augusta presença e, conscientes de nossas fraquezas, adorar em silêncio suas perfeições infinitas que o olho não viu, a orelha não ouviu e tampouco adentrou o coração do homem conceber. Elas estão encobertas numa nuvem profunda para curiosidade humana: é profanidade tentar penetrar essas obscuridades sagradas; e próxima à impiedade de negar sua existência é a temeridade de intrometer-se em sua natureza e essência, decretos e atributos.

2. "Mas para que não penses que minha piedade aqui ficou melhor do que minha filosofia, devo sustentar minha opinião se ela precisar de algum sustento - com uma autoridade grandíssima. Posso citar quase todos os teólogos, desde a fundação do cristianismo, que trataram deste ou de qualquer outro assunto teológico, mas devo confinar-me por ora apenas a um célebre igualmente por piedade e filosofia. É o padre MALEBRANCHE, quem, eu me lembro, assim se expressa ': 'Deve-se', diz ele, 'chamar Deus de espírito não tanto para expressar positivamente o que ele é, mas mais para dizer que ele não é matéria. Ele é um Ser infinitamente perfeito: disto não podemos duvidar. Mas do mesmo modo não devemos imaginar, mesmo supondo-o corpó-

* Recherche de la vérité, liv. 3, chap. 9. [Segue a passagem original: «on ne doit pas tant appeler Dieu un esprit, pour montrer positivement ce qu'il est, que pour signifier qu'il n'est pas matériel. C'est un être infiniment parfait, on n'en peut pas douter. Mais, comme il ne faut pas s'imaginer avec les antropomorphites qu'il doive avoir la figure humaine, à cause qu'elle paraît la plus parfaite, quand même nous le supposerions corporel, il ne faut aussi penser que l'esprit de Dieu ait des pensées humaines, et son esprit soit semblable au nôtre, à cause que nous ne connaissons rien de plus parfait que notre esprit. Il faut plutôt croire que, comme il renferme dans lui-même les perfections de la matière sans être materiel, puisqu'il est certain que la matière a rapport à quelque perfection qui est en Dieu, il comprend aussi les perfections des esprits creés sans être esprit de la manière que nous concevons les esprits; que son nom véritable est Celui qui est, c'est-à-dire l'être sans restriction, tout-être, l'être infini et universel.» Em Hume e a epistemologia, p. 148, João Paulo Monteiro nota que Hume ressaltou uma palavra ausente do original.] 
reo, que ele é revestido por um corpo humano como os ANTROPOMORFISTAS afirmaram a pretexto de que esta figura é a mais perfeita de todas, tampouco devemos imaginar que o Espírito de Deus tem ideias humanas ou mantém qualquer semelhança com o nosso espírito, a pretexto de que não conhecemos nada mais perfeito do que a mente humana. Devemos antes acreditar que como ele compreende as perfeições da matéria sem ser material (...), compreende também as perfeições dos espíritos criados na maneira como concebemos espírito: que seu verdadeiro nome é 'Aquele que é' ou, noutras palavras, Ser sem restrição, Todo o Ser, o Ser infinito e universal."'

3. "Depois de tão grande autoridade, DêMEAs," replicou FILÃO, "como a que produziste e mil outras que podes produzir, pareceria ridículo eu acrescentar minha opinião ou expressar minha aprovação da tua doutrina. Decerto, onde homens razoáveis tratam desses assuntos, a questão nunca pode concernir ao ser, mas apenas à natureza da Deidade. A primeira verdade, como bem podes observar, é inquestionável e autoevidente. Nada existe sem uma causa, e à causa original deste universo (qualquer que seja ela) chamamos Deus e piamente lhe atribuímos todas as espécies de perfeição. Quem quer que tenha escrúpulos em aceitar esta verdade fundamental merece toda punição que possa ser infligida entre filósofos, a saber, o maior ridículo, desdém e desaprovação. Mas como toda perfeição é inteiramente relativa, jamais devemos imaginar que compreendemos os atributos desse Ser divino ou supor que suas perfeições têm alguma analogia ou semelhança com as perfeições duma criatura humana. Sabedoria, pensamento, desígnio, conhecimento: estas lhe atribuímos com justeza porque essas palavras são honoráveis entre homens e não temos outra língua ou outras concepções pelas quais possamos expressar nossa adoração por ele. Mas vamos nos precaver para não pensar que nossas ideias dalgum modo correspondem às suas perfeições ou que seus atributos têm alguma semelhança 
com essas qualidades entre homens. Ele é infinitamente superior a nossa visão e compreensão limitadas, e é mais objeto de adoração no templo do que de disputa nas escolas.

4. "Na realidade, CleANTES," continuou ele, "não há necessidade alguma de ter recurso a esse ceticismo afetado, tão desagradável para ti, para chegar a essa determinação. Nossas ideias não alcançam mais longe do que nossa experiência; nós não temos experiência de atributos e operações divinas: não preciso concluir meu silogismo, podes tu mesmo tirar a inferência. E é um prazer para mim (e espero que também para ti) que raciocínio justo e piedade sã concorram na mesma conclusão e ambas estabeleçam a adoravelmente misteriosa e incompreensível natureza do Ser superior."

5. "Para não perder tempo com circunlóquios," disse CleanTES dirigindo-se a DÊMEAS, "muito menos respondendo às pias declamações de FILÃO, devo explicar brevemente como concebo essa questão. Olha o mundo à volta: contempla a inteireza e cada parte sua: descobrirás que ele nada é senão uma grande máquina, subdividida num número infinito de máquinas menores que também admitem subdivisões até um grau além do que sentidos e faculdades humanas podem traçar e explicar. Todas essas várias máquinas, e mesmo suas mais diminutas partes, são ajustadas umas às outras com uma justeza que arrebata para a admiração todos os homens que as contemplaram. A curiosa adaptação de meios a fins através de toda a natureza se assemelha exatamente, embora muito exceda, às produções de engenho humano, de desígnio, pensamento, sabedoria e inteligência humanas. Uma vez, portanto, que os efeitos se assemelham uns aos outros, somos levados a inferir, por todas as regras de analogia, que as causas também se assemelham, e que o autor da natureza é dalgum modo similar à mente do homem, embora possuidor de faculdades muito maiores, proporcionadas à grandeza do trabalho que ele executou. Por este argumento a posteriori, e por este argu- 
mento apenas, provamos de vez a existência duma Deidade e sua similaridade à mente e inteligência humanas."

6. "Tomarei a liberdade, Cleantes," disse Dêmeas, "de dizer-te que desde o começo não pude aprovar tua conclusão concernente à similaridade da Deidade com os homens, e posso ainda menos aprovar os meios pelos quais tentaste estabelecê-la. O quê! Sem demonstração da existência de um Deus! Sem argumentos abstratos! Sem provas a priori! Serão estas, em que os filósofos têm até agora insistido tanto, todas falácias, todas sofismas? Não poderemos alcançar neste assunto mais do que experiência e probabilidade? Não direi que isto é trair a causa duma Divindade, mas certamente, por essa candura afetada, dás uma vantagem aos ateus que eles nunca poderiam obter pelo mero golpe de argumento e raciocínio."

7. "O que mais receio nesse assunto", disse FILÃo, "não é tanto que todos os argumentos religiosos sejam reduzidos por CLEANTES à experiência, mas antes que eles sequer surjam como os mais certos e irrefragáveis desse tipo inferior. Que uma pedra cairá, que o fogo queimará, que a terra tem solidez, já observamos milhares e milhares de vezes; e quando um novo exemplo dessa natureza é apresentado, tiramos sem hesitação a inferência costumeira. A similaridade exata dos casos nos dá uma segurança perfeita de um evento similar, e uma evidência maior nunca é desejada ou buscada. Mas onde quer que te apartes o mínimo da similaridade dos casos, diminuis proporcionalmente a evidência; e podes por fim ter uma analogia bem fraca, que é confessadamente propensa a erros e incerteza. Depois de termos experimentado a circulação do sangue em criaturas humanas, não temos dúvidas de que ela tem lugar em Tício e Mévio - mas, a partir de sua circulação em sapos e peixes, é apenas uma presunção, embora uma forte, advinda de analogia, que isso tome lugar em homens e outros animais. O raciocínio analógico é muito mais fraco quando inferimos a circulação da seiva em vegetais a 
partir de nossa experiência de que sangue circula em animais, e aqueles que apressadamente seguiram essa analogia imperfeita descobrem, por experimentos mais acurados, estar enganados.

8. "Se vemos uma casa, CLEANTES, concluímos com a maior certeza que ela teve um arquiteto ou construtor - porque esta é precisamente aquela espécie de efeito do qual tivemos experiência de proceder daquela espécie de causa. Mas certamente não afirmarás que o universo sustenta tamanha semelhança com uma casa que possamos com a mesma certeza inferir uma causa similar, ou que a analogia é aqui inteira e perfeita. A dessemelhança é tão arrebatadora que o mais extremo que podes pretender aqui é um palpite, uma conjectura, uma presunção concernente a uma causa similar - e como essa pretensão será recebida no mundo, deixo para ti considerar."

9. "Seria decerto mal recebida", replicou Cleantes, "e eu seria merecidamente culpado e detestado se concedesse que as provas de uma Deidade montassem a não mais do que palpite ou conjectura. Mas será todo o ajuste de meios a fins numa casa e no universo uma semelhança tão tênue? A economia de causas finais? A ordem, proporção e arranjo de cada parte? Degraus duma escada são claramente engendrados para que pernas humanas possam usá-los para escalar, e esta é uma inferência certa e infalível. Pernas humanas também são engendradas para andar e escalar, e esta semelhança, eu concedo, não é tão certa por causa da dessemelhança que apontaste, mas merece portanto o nome apenas de presunção ou conjectura?"

10. "Bom Deus!", bradou DÊMEAS interrompendo-o, "Onde estamos?! Zelosos defensores da religião concedem que as provas duma Deidade sejam insuficientes de evidência perfeita! E tu, FILÃO, de cuja assistência eu dependia para provar o adorável mistério da natureza divina, assentes a todas essas opiniões extravagantes de Cleantes? Pois que outro nome posso dar a elas? Ou por que poupar minha censura quando tais princípios são 
promovidos, sustentados por tal autoridade perante um homem tão jovem como PÂNFILo?"

11. "Pareces não ter notado", replicou FILÃo, "que discuto com CLEANTES à sua própria maneira e, mostrando-lhe as consequências perigosas de seus preceitos, espero por fim reduzi-lo à nossa opinião. Mas ao que te aferras mais, observo, é a representação que Cleantes fez do argumento a posteriori; e, achando que o argumento provavelmente escapa a teu controle e desaparece no ar, pensas que está disfarçado demais para que possas acreditar que esteja posto em sua verdadeira luz. Agora, por mais que eu possa dissentir a outros respeitos dos princípios perigosos de CLEANTES, devo conceder que ele representou com justeza o argumento, e devo tentar apresentar a questão para ti a fim de que não entretenhas mais escrúpulos em relação a ele.

12. "Fosse um homem abstrair de todas as coisas de que sabe ou já viu, seria totalmente incapaz, a partir meramente de suas ideias, de determinar que tipo de cena o universo deve ser ou dar preferência a um estado ou situação de coisas sobre outro. Pois como nada que ele conceba claramente poderia ser estimado impossível ou implicar contradição, toda quimera de sua fantasia poderia estar em pé de igualdade; e tampouco poderia determinar alguma razão justa por que ele adere a uma ideia ou sistema e rejeita outras que são igualmente possíveis.

13. "De novo: depois que abrisse os olhos e contemplasse o mundo tal como realmente é, ser-lhe-ia impossível de primeira atribuir a causa de qualquer evento, e muito menos de todas as coisas e do universo. Ele poderia ver sua fantasia perambulante, e ela poderia trazer-lhe uma variedade infinita de relatos e representações. Todas essas seriam possíveis; mas, sendo todas igualmente possíveis, ele por si só jamais daria uma explicação satisfatória para preferir uma delas às demais. Apenas a experiência pode lhe apontar a verdadeira causa de um fenômeno. 
14. "Ora, de acordo com este método de raciocínio, DÊMEAS, segue-se (e é, de fato, tacitamente admitido pelo próprio CLEANTES) que ordem, arranjo ou ajuste de causas finais não é, por si só, nenhuma prova de desígnio, mas apenas na medida em que se tenha experiência de ela proceder deste princípio. Pois devemos poder saber a priori que a matéria pode conter a fonte ou motor de ordem originariamente em si mesma, assim como a mente; e não há mais dificuldade em conceber que os vários elementos possam a partir duma causa interna desconhecida cair no ajuste mais primoroso, do que conceber que suas ideias numa mente grande, universal, caiam em ordem a partir duma causa igualmente interna, desconhecida. A possibilidade igual de ambas estas suposições é concedida. Pela experiência percebemos (de acordo com Cleantes) que há diferença entre elas. Atira juntos vários pedaços de aço sem desenho ou forma: eles próprios nunca se arranjarão de modo a comporem um relógio; pedra, argamassa, sem um arquiteto nunca erigirão uma casa. A experiência, portanto, prova que há um princípio de ordem na mente, não na matéria. De efeitos similares inferimos causas similares. $\mathrm{O}$ ajuste de meios a fins é semelhante no universo como numa máquina de engenho humano. As causas, portanto, têm que ser semelhantes.

15. "Eu estava desde o começo escandalizado, devo admitir, com essa semelhança que é afirmada entre a Deidade e as criaturas humanas, e devo conceber que isto implica tal degradação do Ser supremo como nenhum teísta são poderia suportar. Com tua assistência portanto, DÊMEAS, devo tentar defender o que chamas com justeza de adorável mistério da natureza divina, e refutar esse raciocínio de CLEANTES, contanto que ele admita que fiz deste uma representação justa."

16. Quando Cleantes assentiu, FILÃo, depois de uma pausa curta, procedeu da seguinte maneira. 
17. “Que todas as inferências, Cleantes, concernentes a fatos são fundadas na experiência, e que todos os raciocínios experimentais são fundados nesta suposição de que causas similares provam efeitos similares e efeitos similares causas similares, não devo agora disputar muito contigo. Mas rogo: observa com que cuidados extremos todos os raciocinadores justos procedem na transferência de experimentos para causas similares. A menos que as causas sejam exatamente similares, não depositam nenhuma confiança perfeita ao aplicar sua observação passada a qualquer fenômeno particular. Cada alteração de circunstâncias ocasiona uma dúvida no que concerne ao evento e requer novos experimentos para provar com segurança que as circunstâncias novas não são de grande importância ou pertinência. Uma mudança no tamanho, situação, arranjo, era, disposição do ar ou objetos à volta - cada um destes particulares pode ser acompanhado pelas consequências mais inesperadas, e a menos que os objetos nos sejam bem familiares, é a maior temeridade esperar com certeza, depois de quaisquer destas mudanças, um evento similar àquele que antes esteve sob nossa observação. Os passos lentos e deliberados dos filósofos aqui, se não em toda parte, são distintos da marcha precipitada dos homens vulgares, que, apressados pela mais diminuta semelhança, são incapazes de qualquer discernimento ou consideração.

18. "Mas podes pensar, Cleantes, que teus usuais fleuma e filosofia foram preservados num passo tão grande como o que tomaste quando comparaste ao universo casas, navios, mobília, máquinas, e de sua similaridade nalgumas circunstâncias inferiste uma similaridade em suas causas? Pensamento, desígnio, inteligência, tais como descobrimos em homens e outros animais, nada mais são do que um dos motores e princípios do universo, assim como calor e frio, atração e repulsão, e uma centena doutros que estão sob nossa observação diária. É uma causa ativa pela qual algumas partes particulares da natureza, vemos, pro- 
duzem alterações noutras partes. Mas poderá uma conclusão, com alguma propriedade, ser transferida de partes para o todo? A grande desproporção não barra toda comparação e inferência? Por observar o crescimento do cabelo podemos aprender alguma coisa sobre a geração do homem? Iria a maneira de brotar duma folha, embora perfeitamente conhecida, conferir-nos alguma instrução sobre vegetação duma árvore?

19. "Mas, admitindo que tivéssemos que tomar as operações duma parte da natureza sobre outra como fundamento de nosso juízo sobre a origem do todo (o que nunca pode ser admitido), ainda assim, por que selecionar um princípio tão diminuto, tão fraco, tão limitado como a razão e desígnio de animais que se encontram existentes neste planeta? Que privilégio peculiar tem essa pequena agitação do cérebro que chamamos de pensamento, para que devamos assim fazê-la o modelo do universo inteiro? Nossa parcialidade a nosso próprio favor de fato o apresenta em todas as ocasiões - mas a filosofia sã deve guardar cuidadosamente contra uma ilusão tão natural.

20. "Longe de admitir", continuou FILÃo, "que as operações duma parte possam nos conferir alguma conclusão justa sobre a origem do todo, não admitirei que nenhuma parte forme uma regra para outra parte, se esta última for muito remota daqueloutra. Há algum fundamento razoável para concluir que os habitantes doutros planetas possuam pensamento, inteligência, razão ou qualquer coisa similar a essas faculdades dos homens? Se a natureza diversificou tão extremamente sua maneira de operação neste pequeno globo, podemos imaginar que ela se copie incessantemente através de tão imenso universo? E se o pensamento, como podemos muito bem supor, for confinado meramente a este canto estreito e tem mesmo aqui uma esfera tão limitada de ação, com que propriedade podemos lhe atribuir a causa original de todas as coisas? As vistas estreitas de um camponês que faça 
das suas economias domésticas a regra para o governo de reinos são em comparação um sofisma perdoável.

21. "Mas estivéssemos tão seguros de que um pensamento e razão assemelhados ao humano se achassem através de todo o universo, e fosse sua atividade em qualquer outro lugar vastamente maior e mais comandante do que aparece neste globo - ainda assim, não consigo ver por que podem as operações dum mundo constituído, arranjado, ser estendidas com qualquer propriedade a um mundo que ainda está em seu estado embrionário e avançando em direção a essa constituição e arranjo. Por observação sabemos algo da economia, ação e nutrição dum animal acabado; mas devemos transferir com grande cuidado esta observação para o crescimento dum feto no útero, e mais ainda para a formação do animálculo nas entranhas do seu pai. A natureza, descobrimos mesmo pela nossa experiência limitada, possui um número infinito de motores e princípios que incessantemente se desvelam a cada mudança de sua posição e situação. E quais princípios novos e desconhecidos a impeliriam para uma situação tão nova e desconhecida como a formação do universo, nós não podemos, sem a mais extrema temeridade, tentar determinar.

22. “Uma parte muito pequena desse grande sistema, durante um tempo muito pequeno, é muito imperfeitamente descoberta para nós - e a partir dela nos pronunciamos decididamente sobre o todo?"

23. "Conclusão admirável! Pedra, madeira, tijolo, ferro, bronze não têm, neste globo diminuto de terra, uma arte e arranjo sem engenho humano: portanto, o universo não poderia atingir sua ordem e arranjo sem algo semelhante a arte humana. Mas uma parte da natureza é regra para outra parte bem variada dela? É regra para o todo? Uma parte bem pequena é regra para o universo? A natureza em certa situação é regra certeira para a natureza noutra situação vastamente diferente daquela? 
24. "E podes culpar-me, ClEANTES, se aqui eu imitar a reserva prudente de SimÔNIDES, que de acordo com a notável história9", sendo-lhe perguntado por Hierão 'O que é Deus?' desejou um dia para pensar nisto, e depois mais dois, e desse modo prolongou continuamente o termo sem jamais trazer sua definição ou descrição? Poderias culpar-me se eu tivesse respondido de primeira que eu não sei e tinha consciência de que esse assunto jaz mui vastamente além do alcance das minhas faculdades? Podes bradar cético e zombeteiro tanto quanto quiseres - mas tendo descoberto, em tantos outros assuntos, serem mais familiares as imperfeições e mesmo contradições da razão humana, eu nunca deveria esperar algum sucesso de suas frágeis conjecturas num assunto tão sublime e tão distante da esfera de nossa observação. Quando duas espécies de objetos sempre foram observadas em conjunção, posso inferir por costume a existência de uma onde quer que eu veja a existência da outra. E isto eu chamo um argumento da experiência. Mas como pode este argumento ter lugar onde os objetos, como no presente caso, são únicos, individuais, sem paralelo ou semelhança específica, pode ser difícil explicar. E quererá algum homem contar-me, mantendo o rosto sério, que um universo ordeiro tem que surgir de algum pensamento e arte como o humano porque temos experiência disto? Para asserir este raciocínio seria necessário que tivéssemos a experiência da origem de mundos, e com certeza não é suficiente que tenhamos visto barcos e cidades surgirem de arte e engenho humanos..."

25. FILÃo estava procedendo nesta maneira veemente, algo entre zombeteira e séria como me pareceu, quando observou alguns sinais de impaciência em CLEANTES e então parou rápido. "O que tenho a sugerir", disse Cleantes, "é apenas que não abuses dos termos nem faças uso de expressões populares para subverter raciocínios filosóficos. Sabes que o vulgo frequentemente distingue razão de experiência mesmo onde a pergunta

$9 \quad \mathrm{ND}, \mathrm{I}, 60$. 
se relaciona apenas a questão de fato e existência, embora se descubra, quando a razão é analisada propriamente, que ela não é nada senão uma espécie de experiência. E um cavilador pode levantar todas as mesmas objeções ao sistema COPERNICANO, o qual incitaste contra meus raciocínios. 'Tendes outras terras', poderá ele dizer, 'que vistes mover? Tendes..."'

26. "Sim!", bradou FILÃo interrompendo-o, "temos outras terras. Não é a lua uma outra terra que vimos dar voltas em torno do seu centro? Não é Vênus uma outra terra onde observamos o mesmo fenômeno? Não são as revoluções do sol também uma confirmação, por analogia, da mesma teoria? Todos os planetas não são terras que giram em torno do sol? Não são os satélites luas que se movem à volta de Júpiter e Saturno e, junto com esses planetas primários, dão voltas ao redor do sol? Estas analogias e semelhanças, junto com outras, são as únicas provas do sistema COPERNICANO - e cabe a ti considerar se tens analogias do mesmo tipo para sustentar tua teoria.

27. "Na realidade, Cleantes," continuou ele, "o sistema moderno de astronomia é agora tão bem recebido por todos os investigadores e se tornou uma parte tão essencial até da nossa educação mais precoce que comumente não somos muito escrupulosos em examinar as razões sobre as quais ele é fundado. Agora é uma questão de mera curiosidade estudar os primeiros escritores deste assunto, que tiveram a força plena do preconceito para batalhar contra eles e foram obrigados a alterar seus argumentos em cada canto a fim de torná-los populares e convincentes. Mas se examinarmos os famosos Diálogos sobre o sistema do mundo de GALILEU, veremos que este grande gênio, um dos mais sublimes que já existiram, empenhou primeiro todas as suas tentativas em provar que não havia fundamento algum para as distinções comumente feitas entre substâncias elementares e celestiais. As escolas, procedendo a partir das ilusões dos sentidos, levaram para muito longe essas distinções, e estabeleceram 
que aquelas últimas substâncias eram inengendráveis, incorruptíveis, inalteráveis, impassíveis; e atribuíram todas as qualidades opostas àqueloutra. Mas GAlileu, começando com a lua, provou sua similaridade em cada particular com a terra: sua figura convexa, sua escuridão natural quando não iluminada, sua densidade, sua distinção entre sólido e líquido, as variações de suas fases, as iluminações mútuas entre a terra e a lua, seus eclipses mútuos, as irregularidades na superfície lunar, etc. Depois de muitos exemplos deste tipo no que diz respeito a todos os planetas, os homens enxergaram claramente que estes corpos se tornaram objetos de experiência, e que a similaridade de sua natureza nos permitiu estender os mesmos argumentos e fenômenos de um para o outro.

28. "Neste procedimento cuidadoso dos astrônomos podes ler tua própria condenação, ClEANTES; ou podes antes ver que o assunto em que te engajas excede toda a razão e investigação humana. Podes pretender mostrar alguma similaridade tal entre a estrutura duma casa e a geração dum universo? Já viste a natureza em alguma situação tal como se assemelha ao primeiro arranjo dos elementos? Mundos já se formaram sob teus olhos? E já tiveste o prazer de observar o progresso inteiro desse fenômeno, desde a primeira aparição de ordem até sua consumação final? Se tiveste, então cita tua experiência e profere tua teoria." 


\section{羽rte III}

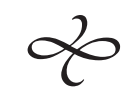

1. "Agora o argumento mais absurdo", replicou Cleantes, "nas mãos dum homem de engenhosidade e invenção, pode adquirir um ar de probabilidade! Não estás ciente, FILão, de que se tornou necessário para COPÉRNICO e seus primeiros discípulos provar a similaridade da matéria terrestre e celeste porque vários filósofos, cegados por velhos sistemas e apoiados nalgumas aparências sensíveis, negaram esta similaridade?, mas que não é de modo algum necessário que teístas provem a similaridade dos trabalhos da natureza àqueles da arte porque tal é autoevidente e inegável? A mesma matéria, uma forma parecida: o que mais é preciso para mostrar uma analogia entre suas causas e afirmar a origem de todas as coisas advinda de propósito e intenção divina? Tuas objeções - tenho de dizer-to tranquilamente - não são em nada melhores do que as cavilações abstrusas daqueles filósofos que negaram o movimento, e devem ser refutadas do 
mesmo modo: por ilustrações e exemplos, ao invés de argumentos sérios e filosofia.

2. "Supõe, portanto, que uma voz articulada foi ouvida nas nuvens, muito mais alta e melodiosa do que qualquer arte humana possa alcançar; supõe que esta voz se estendeu no mesmo instante por todas as nações e falou a cada uma em sua língua e dialeto. Supõe que as palavras proferidas não apenas contêm um sentido e significado justos, mas fornecem alguma instrução inteiramente digna dum Ser benevolente, superior à humanidade: serias capaz de hesitar por um momento a respeito desta voz? E não tens que atribuí-la instantaneamente a algum desígnio e propósito? Ainda não posso ver senão todas as mesmas objeções (se elas merecem este nome) que jazem contra o sistema do teísmo; elas podem também ser produzidas contra esta inferência.

3. "Acaso não poderias dizer que todas as conclusões concernentes a fatos são fundadas em experiência - que quando ouvimos uma voz articulada no escuro e daí inferimos um homem é apenas a semelhança dos efeitos que nos leva a concluir que há uma semelhança parecida na causa -, mas que essa voz extraordinária, por sua altura, extensão e flexibilidade a todas as linguagens, sustenta uma analogia tão pequena com qualquer voz humana que não temos razão para supor uma analogia entre suas causas? E, consequentemente, que uma fala racional, sábia, coerente, procedeu não sabias donde, talvez dum assobio acidental dos ventos, e não dalguma razão ou inteligência divina? Vês claramente tuas próprias objeções nestas cavilações; e, espero também, vês claramente que elas são incapazes de ter mais força num caso do que noutro.

4. "Mas, para trazer o caso para ainda mais perto deste do universo, farei duas suposições que não implicam nem absurdo, nem impossibilidade. Supõe que há uma língua natural, universal, invariável, comum a cada indivíduo de raça humana, e que livros são produções naturais que se perpetuam do mesmo jeito 
que animais e vegetais: por descendência e propagação. Várias expressões de nossas paixões contêm uma língua universal: todos os animais brutos têm uma fala natural que, embora limitada, é bem inteligível para suas próprias espécies. E como há infinitamente menos partes e menos engenho na melhor composição de eloquência do que no corpo organizado mais grosseiro, a propagação duma Ilíada ou duma Eneida é uma suposição mais fácil do que a de qualquer planta ou animal.

5. "Supõe, portanto, que entras em tua biblioteca, povoada assim por volumes naturais, contendo a mais refinada razão e a mais maravilhosa beleza: poderias abrir um deles e duvidar de que sua causa original sustentasse a mais forte analogia com a mente e a inteligência? Quando aquilo raciocinasse e discursasse, quando protestasse, argumentasse e reforçasse suas opiniões e tópicos; quando se aplicasse às vezes ao intelecto puro, às vezes às afecções; quando coletasse, dispusesse e adornasse alguma consideração adequada ao objeto - poderias persistir em afirmar que tudo isso realmente não tem mesmo nenhum significado e a primeira formação desse volume nas entranhas do seu pai original não procedeu de pensamento e desígnio? Tua teimosia, eu sei, não alcança tal grau de firmeza: até tua brincadeira e licenciosidade céticas ficariam vexadas ante um absurdo tão manifesto.

6. "Mas se houver alguma diferença, FILÃo, entre esse caso suposto e o caso real do universo, toda a vantagem está neste último. A anatomia dum animal confere exemplos muito mais fortes de desígnio do que o exame de Lívio ou Tácito - e qualquer objeção que lançaste naquele caso, conduzindo-me de volta para uma cena tão inusual e extraordinária como a formação de mundos, terá igual lugar no caso da biblioteca vegetativa. Escolhe, pois, teu partido, FILÃO, sem qualquer ambiguidade ou evasão: afirma ou que um volume racional não é prova de causa racional ou admite uma causa similar para todos os trabalhos da natureza. 
7. "Deixa-me observar também aqui", continuou CleANTES, "que este argumento religioso, ao invés de se enfraquecer por esse ceticismo tão afetado por ti, antes adquire força por ele e torna-se mais firme e indisputável. Excluir todo raciocínio ou argumento de todo tipo é ou afetação ou loucura. A profissão declarada de todo cético razoável é rejeitar apenas argumentos abstrusos, remotos e refinados, aderir ao senso comum e aos instintos simples da natureza e assentir onde quer que algumas razões o arrebatem com uma força tão grande que ele não possa, sem a maior violência, impedi-lo. Ora, os argumentos para a religião natural são claramente deste tipo, e nada senão a metafísica mais perversa e obstinada pode rejeitá-los. Considera, anatomiza o olho: examina sua estrutura e engenho e diz-me, pelo teu próprio sentimento, se a ideia de um engendrador não flui imediatamente sobre ti com uma força tal como a duma sensação. A conclusão mais óbvia é decerto em favor do desígnio, e é preciso tempo, reflexão e estudo para evocar essas objeções frívolas, embora abstrusas, que podem sustentar infidelidade. Quem poderá contemplar o macho e a fêmea de cada espécie, a correspondência de suas partes e instintos, suas paixões e todo o curso da vida antes e depois da geração, sem ficar cônscio de que a propagação das espécies é pretendida pela natureza? Milhões e milhões de tais exemplos se apresentam através de cada parte do universo, e nenhuma língua pode exprimir um significado mais inteligível, irresistível, do que o curioso ajuste de causas finais. Que grau, portanto, de dogmatismo cego deve-se alcançar para rejeitar argumentos tão naturais e convincentes?

8. ${ }^{10}$ "Há certas belezas na escrita, com as quais podemos nos deparar, que parecem contrárias a regras e que ganham afecções e animam a imaginação em oposição a todos os preceitos da crítica e às autoridades dos mestres da arte estabelecidos. E se o argumento para o teísmo for, como pretendes, contraditório aos

10 Este parágrafo foi acrescentado entre 1751 e 1763. 
princípios da lógica, sua influência universal, irresistível, prova claramente que pode haver argumentos duma natureza irregular parecida. Por mais que cavilações possam ser incitadas, um mundo ordeiro, bem como fala coerente, articulada, ainda será recebido como uma prova incontestável de desígnio e intenção.

9. "Algumas vezes acontece, admito, de os argumentos religiosos não terem sua devida influência sobre um selvagem ignorante e bárbaro; não porque são obscuros e difíceis, mas porque ele nunca se questiona a seu respeito. Donde surge a curiosa estrutura dum animal? Da cópula de seus pais. E estes, donde? Dos pais deles. Uns poucos removem a série de objetos a tal distância que para ele se perdem em escuridão e confusão; e tampouco ele é movido por alguma curiosidade a pesquisá-los até mais longe. Mas isto não é nem dogmatismo nem ceticismo; é estupidez, um estado de mente muito diferente da tua disposição esmiuçadora e inquisitiva, meu engenhoso amigo. Podes remontar a causas a partir de efeitos, podes comparar os mais distantes e remotos objetos, e teus maiores erros procederem não da esterilidade de pensamento e invenção, mas duma fertilidade luxuriante demais, que suprime teu bom-senso natural com uma profusão de escrúpulos e objeções desnecessários."

10. Aqui pude observar, Hermipo, que Filão estava um pouco embaraçado e confuso: mas enquanto ele hesitava em proferir uma resposta, para sua sorte DÊMEAS interrompeu o discurso e livrou-lhe a cara.

11. "Teu exemplo, Cleantes," disse ele, "tirado dos livros e da língua, sendo familiar, teve, confesso, muito mais força nessa explicação; mas não há algum perigo nessa circunstância mesma?, e isso não pode nos tornar presunçosos ao nos fazer imaginar que compreendemos a Deidade e temos ideia de sua natureza e atributos? Quando leio um volume, entro na mente e intenção do autor: eu mo torno, de certo modo, naquele instante, e tenho um sentimento e concepção imediatos daquelas ideias que se 
revolveram em sua imaginação enquanto estava empregado naquela composição. Mas tal aproximação nunca podemos fazer da Deidade com segurança. Seus meios não são nossos meios. Seus atributos são perfeitos, mas incompreensíveis. E esse volume da natureza contém um grande e inexplicável enigma, mais do que qualquer discurso ou raciocínio inteligível.

12. "Os antigos Platônicos, tu o sabes, foram os mais religiosos e devotos de todos os filósofos pagãos; ainda assim, muitos deles - em particular Plotino - declararam expressamente que o intelecto ou entendimento não pode ser atribuído à Deidade, e que nossa mais perfeita adoração a ela consiste não em atos de veneração, gratidão ou amor, mas em certa autoaniquilação misteriosa ou extinção total de nossas faculdades. Tais ideias são, talvez, muito exageradas, mas ainda se deve reconhecer que ao representar a Deidade como tão inteligível e compreensível, e tão similar à mente humana, somos culpados da parcialidade mais grosseira e estreita, e fazemos de nós mesmos o modelo de todo o universo.

13. ${ }^{11 ~ " T o d o s ~ o s ~ s e n t i m e n t o s ~ d a ~ m e n t e ~ h u m a n a ~-~ g r a t i d a ̃ o, ~ r e s-~}$ sentimento, amor, amizade, aprovação, culpa, piedade, emulação, inveja -, têm uma referência plena ao estado e situação do homem, e são calculados para preservar a existência e promover a atividade de certo ser em certas circunstâncias. Todas as nossas ideias, derivadas dos sentidos, são confessadamente falsas e ilusórias; não podem, portanto, ser suspeitas de ter lugar numa inteligência suprema. E como as ideias de sentimento interno, acrescentadas àquelas dos sentidos externos, compõem todo o equipamento do entendimento humano e devemos assim concluir que nenhuns dos materiais do pensamento são em algum respeito iguais à maneira de pensar, como podemos fazer alguma comparação entre elas ou supô-las dalgum jeito assemelhadas? Nosso pensamento é flutuante, incerto, passageiro, sucessivo e

11 Este parágrafo foi acrescentado entre 1751 e 1763. 
composto; e fôssemos remover essas circunstâncias, aniquilaríamos absolutamente sua essência, e seria em tal caso um abuso de termos aplicar a isso o nome de pensamento ou razão. No mínimo, se parecer mais pio e respeitoso (como realmente o é) ainda reter esses termos, quando mencionamos o Ser supremo temos de reconhecer que seu significado neste caso é totalmente incompreensível, e que as debilidades de nossa natureza não nos permitem alcançar ideias que correspondam minimamente à sublimidade inefável dos atributos divinos." 


\section{Parte IV}

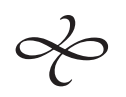

1. "Parece-me estranho", disse Cleantes, "que tu, Dêmeas, que és tão sincero na causa da religião, ainda mantenhas a natureza da Deidade misteriosa, incompreensível, e insistas tão arduamente que ela não tem nenhum modo de semelhança ou similaridade com criaturas humanas. A Deidade, posso admitir prontamente, possui muitos poderes e atributos dos quais não podemos ter nenhuma compreensão: mas se nossas ideias, até onde alcançam, não forem justas e adequadas, e correspondentes à sua real natureza, não sei o que haveria nesse assunto de digno de se insistir. O nome, sem qualquer significado, é dotado de importância tão poderosa? Ou como vós, Místicos, que sustentais a incompreensibilidade absoluta da Deidade, diferis de céticos ou ateus, que afirmam que a causa do Todo é desconhecida e ininteligível? Sua temeridade terá que ser bem grande se, depois de rejeitarem a produção por uma mente, quero dizer, uma mente assemelhada 
à humana (pois não conheço nenhuma outra), eles pretenderem atribuir com certeza qualquer outra causa específica e inteligível - e sua consciência terá que ser de fato bem escrupulosa, se se recusarem a chamar a causa universal, desconhecida, de Deus ou Deidade e a outorgar-lhe tantos elogios sublimes e epítetos sem significado quanto quiseres lhes pedir."

2. "Quem poderia imaginar", replicou Dêmeas, "que Cleantes, o calmo, filosófico ClEANTES, tentaria refutar seus antagonistas afixando-lhes um apelido e, qual carolas comuns e inquisidores da era, ter recurso a invectiva e declamação ao invés de raciocínio? Ou acaso não perceberá que estes tópicos são facilmente replicados e que antropomorfista é uma designação tão odiosa e implica consequências tão perigosas quanto o epíteto de místico com o qual ele nos honrou? Na realidade, ClEANTES, considera o que é que asseres quando representas a Deidade similar à mente e entendimento humanos. O que é a alma do homem? Uma composição de várias faculdades, paixões, sentimentos e ideias unidas, de fato, num único ego ou pessoa, mas ainda distintas umas das outras. Quando raciocina, as ideias que são as partes do seu discurso se arranjam numa certa forma ou ordem que não é preservada inteira por um momento, mas imediatamente dá lugar a outro arranjo. Novas opiniões, novas paixões, novas afecções, novos sentimentos surgem, os quais diversificam o cenário mental e produzem neste a maior variedade e a mais rápida sucessão imaginável. Como isto é compatível com aquela perfeita imutabilidade e simplicidade que todos os teístas atribuem à Deidade? Pelo mesmo ato, dizem eles, ela vê passado, presente e futuro; seu amor e seu ódio, sua piedade e sua justiça, são uma operação individual; ela está presente em cada ponto do espaço e completa em cada instante de duração. Sem sucessão, sem mudança, sem aquisição, sem diminuição. O que ela é não implica nem uma sombra de distinção ou diversidade. E o que ela é neste momento ela sempre foi e sempre será, sem qualquer novo juízo, 
sentimento ou operação. Fica fixa num estado simples, perfeito; e tampouco podes dizer com alguma propriedade que esse ato dela é diferente daqueloutro, ou que aquele juízo ou ideia foi formado mais tardiamente e dará lugar, por sucessão, a certo juízo ou ideia diferente."

3. "Posso admitir prontamente", disse Cleantes, "que aqueles que mantêm a simplicidade perfeita do Ser supremo na extensão em que a explicaste são místicos completos e acusáveis de todas as consequências que tirei de sua opinião. São, numa palavra, ateus sem saber disto. Pois embora se admita que a Deidade possua atributos dos quais não temos compreensão, ainda assim jamais devemos lhe imputar quaisquer atributos que sejam incompatíveis com aquela natureza inteligente que lhe é essencial. Uma mente cujos atos, sentimentos e ideias não são distintos e sucessivos, que é inteiramente simples, totalmente imutável, é uma mente que não tem nenhum pensamento, nenhuma razão, nenhuma vontade, nenhum sentimento, nenhum amor, nenhum ódio - ou, numa palavra, não é nenhuma mente. É um abuso de termos dar a isto esta designação, e podemos tão bem falar de extensão limitada sem figura ou de número sem composição."

4. "Rogo que consideres", disse FILÃo, "quem estás condenando agora. Honras com a designação de ateu quase todos os teólogos sãos, ortodoxos, que trataram deste assunto, e descobrirás ser tu próprio, de acordo com tua avaliação, o único teísta são do mundo. Mas se idólatras forem ateus, como acho que se pode asserir com justeza, e teólogos cristãos igualmente, o que acontece com o tão celebrado argumento derivado do consenso universal da humanidade?

5. "Mas porque sei que não és muito influenciado por nomes e autoridades, tentarei mostrar-te, com um pouco mais de distinção, as inconveniências desse antropomorfismo que abraçaste, e hei de provar que não há fundamento para supor que um plano do mundo tenha se formado na mente divina, consistindo em 
ideias distintas arranjadas diferentemente, do mesmo modo que um arquiteto forma em sua cabeça o plano de uma casa que pretende executar.

6. "Não é fácil, admito, ver o que se ganha por esta suposição, quer julguemos a questão pela razão, quer pela experiência. Ainda ficamos obrigados a escalar mais alto para achar a causa dessa causa, que assinalaste como satisfatória e conclusiva.

7. ${ }^{12}$ "Se a razão, (quero dizer a razão abstrata, derivada de investigações a priori) não for igualmente muda a respeito de todas as questões relativas a causa e efeito, no mínimo esta proposição se atreverá pronunciar: 'Um mundo mental ou universo de ideias requer uma causa tanto quanto um mundo material ou universo de objetos; e, se similar em seu arranjo, tem que requerer uma causa similar'. Pois o que há nesse assunto que devesse ocasionar uma conclusão ou inferência diferente? Num aspecto abstrato, eles são inteiramente semelhantes; e nenhuma dificuldade acompanha uma suposição sem ser comum a ambas.

12 Entre 1751 e 1763, este parágrafo substituiu o que segue: “Quando consultamos a razão, todas as causas e efeitos parecem igualmente explicáveis a priori, e tampouco é possível determinar umas e outros por mera contemplação abstrata de sua natureza, sem consultar a experiência ou considerar o que descobrimos resultar da operação de objetos. E se essa proposição for verdadeira em geral, que a razão, julgando a priori, descobre serem todas as causas e efeitos igualmente explicáveis, deve parecê-lo ainda mais quando comparamos o mundo exterior de objetos àquele mundo de pensamento, que é representado como sua causa. Se a razão nos diz que o mundo de objetos requer uma causa, ela deve nos dar a mesma informação sobre o mundo de pensamento - e se um parece à razão requerer uma causa dalgum tipo particular, a outra tem que requerer uma causa dum tipo parecido. Qualquer proposição, portanto, que possamos formar sobre a causa do primeiro, se for consistente ou inteligível ou necessária, tem também que parecer à razão consistente ou inteligível ou necessária quando aplicada ao último, tal como o descreveste, e vice-versa. É claro então que, até onde a razão abstrata possa julgar, é perfeitamente indiferente se estamos no universo de matéria ou no de pensamento, e não ganhamos nada remontando um ao outro." Hume riscou esta passagem, depois acrescentou duas vezes à margem: "Escreve estas linhas, embora apagadas", e em ambos os casos riscou as instruções. 
8. "De novo: quando forçarmos a experiência a pronunciar alguma proposição mesmo nesses assuntos que jazem além de sua esfera, ela não só não pode perceber uma diferença material entre dois tipos de mundo nesse particular, como os encontra governados por princípios similares e dependentes duma variedade de causas igual em suas operações. Temos espécies em miniatura de ambos os mundos. Nossa própria mente se assemelha a um; um corpo animal ou vegetal, ao outro. Que a experiência, portanto, julgue a partir destas amostras. Nada parece mais delicado no que diz respeito a suas próprias causas do que o pensamento, e como essas causas jamais operaram da mesma maneira em duas pessoas, então jamais encontraremos duas pessoas que pensem exatamente igual. Nem, de fato, a mesma pessoa pensa exatamente igual em dois períodos diferentes. Uma diferença de idade, da disposição do seu corpo, do clima, da comida, da companhia, de livros, de paixões: quaisquer destes particulares e outros ainda mais miúdos são suficientes para alterar a curiosa maquinaria e para comunicar-lhe movimentos e operações bem diferentes. Até onde possamos julgar, corpos animais e vegetais não são mais delicados em seus movimentos, nem dependem de uma variedade mais grandiosa ou ajuste mais curioso de motores e princípios.

9. "Como, portanto, devemos nos satisfazer quanto à causa desse Ser que supões o Autor da natureza ou, de acordo com teu sistema de antropomorfismo, o mundo ideal ao qual remontas o mundo material? Não temos a mesma razão para remontar esse mundo ideal a outro mundo ideal ou a um novo princípio inteligente? Mas se pararmos e não formos mais longe - para que ir mais longe? Por que não pararmos no mundo material? Como podemos nos satisfazer sem prosseguirmos in infinitum? E afinal, qual satisfação há nessa progressão infinita? Lembremonos da história do filósofo INDIANO e seu elefante ${ }^{13}$. Isto nunca foi

13 Hume na certa lera a historieta na seção 19 do capítulo XIII do livro II do Ensaio sobre o entendimento humano, de Locke. Como para o filósofo indiano 
mais aplicável do que no presente assunto. Se o mundo material repousar sobre um mundo ideal similar, este mundo ideal terá que repousar sobre algum outro, e assim por diante, sem um fim; seria melhor, portanto, nunca olharmos para além do presente mundo material. Ao supormos que ele contenha em si próprio o princípio de sua própria ordem, realmente afirmamos que ele é Deus; e quanto mais cedo chegamos a esse Ser divino, melhor. Quando dás um passo além do sistema mundano, apenas excitas um humor investigativo que é impossível de ser satisfeito.

10. “Dizer que as diferentes ideias que compõem a razão do Ser supremo se ordenam por si sós e por sua própria natureza é, realmente, falar sem qualquer significado preciso ${ }^{14}$. Caso tenha um significado, eu ficaria contente em saber por que isto não é de tanto bom-senso quanto dizer que as partes do mundo material se ordenam por si sós por sua própria natureza. Poderá uma opinião ser inteligível enquanto a outra não?

11. "Temos, de fato, experiência de ideias se ordenando por si sós e sem qualquer causa conhecida - mas estou certo de que também temos uma experiência muito mais larga da matéria fazendo o mesmo, como em todos os exemplos de geração e vegetação, onde a análise acurada da causa excede toda a compreensão humana. Temos também experiência do pensamento e da matéria que não têm nenhuma ordem: do primeiro, a loucura; da outra, a corrupção. Por que, então, devemos pensar que a ordem é mais essencial a um do que à outra? E se ela requer uma causa em ambos, o que ganhamos pelo teu sistema, remontando

o mundo não poderia ficar solto no espaço, haveria de repousar sobre um grande elefante. Mas sobre o que estaria o elefante? Para Locke, bastaria, sem elefantes, respondermos desde o começo que repousa sobre substância, mesmo que não saibamos direito o que esta significa - solução, sem dúvida, também nada humeana, já que a clareza das ideias é indispensável em discussões filosóficas.

14 Em rasura feita entre 1751 e 1763, "qualquer significado preciso" substituiu "um significado". 
o universo de objetos a um universo de ideias similar? O primeiro passo que damos nos conduz à eternidade. Ser-nos-ia sábio, portanto, limitar nossas investigações ao mundo presente sem olhar para mais longe. Jamais se pode conseguir satisfação alguma através dessas especulações que excedem tanto os limites estreitos do entendimento humano.

12. "Foi usual entre os Peripatéticos, sabes, CleAnTES, quando a causa dalgum fenômeno era demandada, ter recurso às suas faculdades ou qualidades ocultas e dizer, por exemplo, que o pão nutria por sua faculdade nutritiva e o sene purgava por seu purgativo. Mas descobriu-se que este subterfúgio nada era senão disfarce de ignorância, e que esses filósofos, embora menos ingênuos, na verdade diziam o mesmo que os céticos ou o vulgo, que de bom grado confessaram desconhecer a causa desses fenômenos. De modo parecido, quando se pergunta qual causa produz ordem nas ideias do Ser supremo, pode outra razão ser assinalada por vós, antropomorfistas, senão que é uma faculdade racional, e que tal é a natureza da Deidade? Mas, por que uma resposta similar não será igualmente satisfatória para dar conta da ordem no mundo sem ter recurso a qualquer Criador inteligente como insistes, pode ser difícil determinar. Basta dizer que tal é a natureza dos objetos materiais e que eles são todos originariamente possuidores duma faculdade de ordem e proporção. Estes são apenas meios mais estudados e elaborados de confessarmos nossa ignorância, e tampouco tem uma hipótese qualquer vantagem real sobre a outra, exceto por sua maior conformidade com preconceitos vulgares."

13. "Expuseste o argumento com grande ênfase", replicou Cleantes, "Não pareces ter consciência do quão fácil é responder-lhe: Mesmo na vida comum, se eu apontar uma causa para certo evento, acaso haverá qualquer objeção, FILÃo, a que eu não possa apontar a causa dessa causa e responder a toda nova questão que se possa se incessantemente levantar? E que filósofos 
poderiam se submeter a uma regra tão rígida? - filósofos, que confessam serem as causas últimas totalmente desconhecidas, e que têm consciência de os princípios mais refinados, aos quais eles remontam os fenômenos, lhes serem ainda tão inexplicáveis quanto esses mesmos fenômenos o são para o vulgo. A ordem e arranjo da natureza, o curioso ajuste de causas finais, o claro uso e intenção de cada parte e órgão: tudo isto manifesta na linguagem mais clara uma causa inteligente ou Autor. Os céus e a terra se aliam no mesmo testemunho, todo o coro da natureza eleva um hino de louvores ao Criador - tu sozinho, ou quase sozinho, perturbas esta harmonia geral. Levantas dúvidas, cavilações e objeções abstrusas: perguntas-me qual é a causa dessa causa? Eu não sei, eu não ligo, isso não me preocupa. Encontrei uma Deidade, e aqui paro minha investigação. Que sigam adiante os que forem mais sábios ou mais empreendedores."

14. "Não pretendo ser uma coisa nem outra", replicou FILÃO, “E é por esta mesma razão que eu talvez nunca tenha tentado ir tão longe, especialmente quando estou ciente de que terei ao cabo que me contentar em sentar com a mesma resposta que, sem problemas mais longínquos, poderia ter me satisfeito desde o começo. Se ainda deverei permanecer em total ignorância de causas e não poderei dar explicação para absolutamente nada, nunca hei considerar vantajoso postergar por um momento uma dificuldade que, reconhece-lo, de imediato recairá com plena força sobre mim. Os naturalistas, de fato, explicam com muita justeza efeitos particulares por causas mais gerais, embora estas próprias causas gerais devam ao cabo permanecer totalmente inexplicáveis - mas decerto jamais acharam satisfatório explicar um efeito particular por uma causa particular que não precisou ser mais explicada do que o próprio efeito. ${ }^{15}$ Um sistema ideal,

15 Em revisão feita entre 1751 e 1763, o começo deste parágrafo até este ponto substituiu: "Tua resposta pode, talvez, ser boa," disse Filão, "com base em teus princípios de que o sistema religioso pode ser provado pela experiência, e ape- 
arranjado por si só, sem um desígnio precedente, não é nem um pouquinho mais explicável do que um material que atinge sua ordem duma maneira parecida, e tampouco há mais dificuldade na primeira suposição do que na última."

nas pela experiência, e de que a Deidade surgiu dalguma causa exterior. Mas estas opiniões, sabe-lo, serão adotadas por pouquíssimos. E para todos aqueles que raciocinam com base noutros princípios e ainda negam a simplicidade misteriosa da natureza divina, minha objeção ainda permanece boa." 


\section{Parte V}

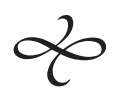

1. "Mas para mostrar-te ainda mais inconveniências", continuou FILÃo, "em teu antropomorfismo, peço que faças um novo exame dos teus princípios. 'Efeitos semelhantes provam causas semelhantes': Este é o argumento experimental, e este, dize-lo também, é o único argumento teológico. Ora, é certo que, quanto mais parecidos são os efeitos que se veem e mais parecidas são as causas que se inferem, mais forte é o argumento. Todo desvio de cada lado diminui a probabilidade e torna o experimento menos conclusivo. Não podes duvidar deste princípio nem rejeitar suas consequências.

2. "Todas as descobertas na astronomia que provam a imensa grandeza e magnitude dos trabalhos da natureza são tantos mais argumentos adicionais para uma Deidade, de acordo com o verdadeiro sistema do teísmo - mas, de acordo com tuas hipóteses de teísmo experimental, elas se tornam tantas objeções mais, por 
removerem o efeito para mais longe de toda semelhança com os efeitos de arte e engenho humanos. Pois se LUCRÉCIO*, mesmo seguindo o velho sistema de mundo, podia exclamar
Quis regere immensi summam, quis habere profundi
Indu manu validas potis est moderanter habenas?
Quis pariter cœlus omnes convertere? et omnes
Ignibus ætheriis terras suffire feraces?
Omnibus inve locis esse omni tempore præsto?

Se TÚLIO* achou este raciocínio tão natural para pô-lo na boca dum EPICURISTA: 'Quibus enim oculis animi intueri potuit vester Plato fabricam illa tanti operis, qua construi a Deo atque cedificari mundum facit? qua molitio? qua ferramenta? qui vectes? quœe maquince? qui ministri tanti muneris fuerunt? quemadmodum autem obedire et parere voluntati architecti aer, ignis, aqua, terra potuerunt?'; se este argumento, digo eu, teve alguma força em eras mais antigas, o quão maior deve não tê-la agora, quando os limites da natureza foram tão imensamente alargados, e um cenário tão magnificente nos foi aberto? É ainda menos razoável formar nossa ideia duma causa tão ilimitada a partir de nossa experiência das produções estreitas de desígnio e invenções humanas.

3. "As descobertas de microscópios, por abrirem um novo universo em miniatura, são ainda objeções de acordo contigo;

* [RN] Liv. II, 1095. ["quem poderia ter mãos bastante firmes para manejar as fortes rédeas do infinito, quem poderia fazer girar harmoniosos todos os céus, aquecer com fogo todas as terras fertilizadas, em todos os lugares, em todos os tempos [...]?"]

* De Nat. Deor., Liv. I [Em português: “Pois com que olhos d'alma terá podido o vosso Platão contemplar aquela fábrica de tanto trabalho, com a qual faz o mundo ter sido contruído e edificado por um deus? com que método de engenharia? com quais ferramentas? com quais alavancas? com quais máquinas? quem foram os ministros de tantas tarefas? de que modo ar, fogo, água e terra puderam obedecer e executar a vontade do arquiteto?"] 
argumentos, de acordo comigo. Para quanto mais longe empurramos nossas investigações deste tipo, mais somos levados a inferir que a causa universal do Todo é vastamente diferente da espécie humana ou de qualquer objeto de experiência e observação humanas.

4. "E o que dizes das descobertas em anatomia, química, botânica...?" "Estas certamente não são objeções:", disse ClEANTES, "elas apenas desvelam novos exemplos de arte e engenho. Ainda é a imagem da mente refletida sobre nós a partir de inúmeros objetos." "Acrescenta: uma mente parecida com a humana", disse Filão. "Não conheço nenhuma outra", replicou Cleantes. "E quanto mais parecida, melhor", insistiu FILÃo. "Com certeza", disse Cleantes.

5. "Agora, Cleantes," disse Filão com um ar de presteza e triunfo, "nota as consequências. Primeira: por este método, renuncias a todas as reivindicações de infinitude em quaisquer dos atributos da Deidade. Pois como a causa deve apenas ser proporcionada ao efeito, e o efeito, até onde sabemos, não é infinito, que pretensões temos, baseados em tuas suposições, de atribuí -la ao Ser divino? Ainda insistirás que, removendo este Ser para tão longe de toda similaridade com criaturas humanas, inclinamo-nos para as hipóteses mais arbitrárias e ao mesmo tempo enfraquecemos todas as provas de sua existência.

6. "Segunda: não tens razão alguma, com base em tua teoria, para atribuir perfeição à Deidade, mesmo em sua capacidade finita, ou para supô-la livre de todo erro, falha ou incoerência em seus empreendimentos. Há muitas dificuldades inexplicáveis nos trabalhos da natureza, as quais, caso admitamos que um Autor perfeito está provado a priori, se dissolvem facilmente e tornamse apenas dificuldades aparentes, oriundas da capacidade estreita do homem, que não pode remontar a relações infinitas. Mas, de acordo com o teu método de raciocínio, essas dificuldades se tornam todas reais, e talvez se insista nelas como novos exemplos 
de semelhança com arte e engendro humanos. No mínimo deves reconhecer que nos é impossível dizer, a partir de nossas vistas estreitas, se este sistema contém alguma falha grande ou merece algum elogio considerável se comparado a outros sistemas possíveis ou até reais. Acaso poderia um camponês, se a EnEIDA fosse lida para ele, dizer que este poema é absolutamente impecável ou atribuir-lhe o posto adequado dentre as produções do espírito humano?, ele, que nunca viu outra produção?

7. ${ }^{16}$ "Mas fosse mesmo este mundo uma produção tão perfeita, deveria ainda permanecer incerto se todas as excelências do trabalho podem ser, com justeza, atribuídas ao operário. Se examinarmos um navio, que ideia exaltada não formaremos da engenhosidade do carpinteiro que forjou uma máquina tão complicada e bela? E que surpresa não teremos quando descobrirmos um mecânico estúpido que imitou outros e copiou uma arte que, através duma longa sucessão de eras, depois de múltiplas tentativas, erros, deliberações e controvérsias, tem sido melhorada gradualmente? Muitos mundos podem ter sido remendados e estropiados através duma eternidade antes de este sistema ser descoberto: na arte de fazer mundos, muito trabalho pode ter sido perdido, muitas tentativas infrutíferas terem sido feitas e um melhoramento lento, porém contínuo, ter sido levado adiante por infinitas eras. Em tais assuntos, quem pode determinar onde está a verdade? Mais ainda, quem pode conjecturar onde está a probabilidade, em meio a um número de hipóteses que podem ser propostas e um número maior ainda que pode ser imaginado?

8. "E qual sombra de argumento", continuou FILÃO, "podes produzir a partir de tuas hipóteses para provar a unidade da Deidade? Um grande número de homens se alia ao construir uma casa ou navio, ao erguer uma cidade, ao forjar uma comunidade: por que não podem combinar-se várias Deidades ao engen-

16 Este parágrafo e o 9 foram acrescentados entre 1751 e 1763. 
drarem e forjarem um mundo? Isto é apenas uma similaridade muito maior com negócios humanos. Dividindo o trabalho entre várias, podemos ademais limitar os atributos e nos livrar daqueles poder e conhecimento extensivos que, de acordo contigo, podem apenas servir para enfraquecer a prova de sua existência. E se criaturas tão tolas, tão viciosas como o homem podem ainda se unir e executar um plano, o quão mais não poderão essas Deidades ou Demônios, que podemos supor mais perfeitos em vários graus?

9. “Multiplicar causas sem necessidade é, de fato, contrário à verdadeira filosofia - mas este princípio não se aplica ao presente caso. Fosse uma Deidade anteriormente provada por tua teoria, a qual fosse possuidora de cada atributo necessário à produção do universo, seria desnecessário, admito (embora não absurdo), supor qualquer outra Deidade existente. Mas enquanto ainda é questionável se todos esses atributos estão unidos num único sujeito ou dispersos entre vários Seres independentes, através de quais fenômenos da natureza poderemos pretender resolver a controvérsia? Quando vemos um corpo elevado num prato de balança, temos certeza de que há no prato oposto, embora escondido das vistas, alguma contraparte de peso igual - mas ainda é permitido duvidar se esse peso é um agregado de vários corpos distintos ou uma massa uniforme unida. ${ }^{17} \mathrm{E}$ se o peso necessário excede muito qualquer coisa que tenhamos visto conjuntas num corpo único, a primeira suposição parece ainda mais provável e natural. Um Ser inteligente de poder e capacidade tão vastos quanto os necessários para produzir o universo - ou, para falar a linguagem da filosofia antiga, um tão prodigioso animal - excede toda analogia e mesmo compreensão.

10. "Mas mais ainda, CleAnTEs, homens são mortais e renovam sua espécie por geração, e isto é comum a toda criatura vi-

17 Esta mesma imagem aparece na Investigação sobre o entendimento humano, XI, $\S 12$. 
vente. Os dois grandiosos sexos do macho e da fêmea, diz MiLTON, animam o mundo. Por que esta circunstância tão universal, tão essencial, tem que ser excluída dessas Deidades limitadas e numerosas? Contempla, então, a teogonia dos tempos antigos nos ser devolvida.

11. "E por que não tornar-se um antropomorfista perfeito? Por que não asserir que a Deidade ou as Deidades são corpóreas e têm olhos, um nariz, boca, orelhas, etc.? EPICURO sustentou que homem algum viu razão fora duma figura humana, portanto os deuses têm que ter uma figura humana ${ }^{18}$. E este argumento, que é merecidamente tão ridicularizado por CícERo, se torna, de acordo contigo, sólido e filosófico.

12. "Numa palavra, Cleantes, um homem que siga tua hipótese é capaz, talvez, de asserir ou conjecturar que o universo nalgum tempo surgiu dalgo parecido com desígnio - mas, além desta posição, ele não poderá descobrir uma única circunstância e ficará autorizado em seguida para fixar qualquer ponto de sua teologia pela mais extrema licença de fantasia e de hipótese. Este mundo, pelo que ele saiba, é muito faltoso e imperfeito comparado a certo padrão superior, e foi apenas o primeiro ensaio rude dalguma Deidade criança que depois o abandonou, envergonhada de seu desempenho parco; é apenas o trabalho dalguma Deidade dependente, inferior, e é objeto de escárnio por parte dos seus superiores; é a produção da velhice e senilidade nalguma Deidade aposentada, e desde a morte dela tem percorrido aventuras a partir do primeiro impulso que lhe fora dado... Com justeza dás sinais de horror, DÊMEAS, a estas suposições estranhas - mas estas e milhares doutras deste mesmo tipo são suposições

18 Cf. ND, I, 48: "Se a figura do homem supera todas as formas animais e de fato o deus é um animal, sua figura [i.e., a divina] certamente é a mais bela de todas; e porquanto consta que o deus é felicíssimo, e de fato ninguém pode ser feliz sem virtude nem virtuoso sem razão, e consta que a razão não existe senão em figura humana, está demonstrado que a representação (species) do homem é a do deus." 
de Cleantes, não minhas. A partir do momento em que os atributos da Deidade se supõem finitos, todas estas têm lugar. E não posso, de minha parte, pensar que um sistema de teologia tão extravagante e desordenado seja, a qualquer respeito, preferível a não ter sistema nenhum."

13. "Estas suposições eu repudio absolutamente!", bradou Cleantes, "Elas, contudo, não me impressionam com horror algum; em especial quando propostas dessa maneira divagadora como tu as deixas escapulir. Ao contrário, dão-me prazer quando vejo que, pela indulgência mais extrema de tua imaginação, jamais te livraste da hipótese do desígnio no universo, mas estás obrigado, a todo momento, a ter recurso a ela. A esta concessão adiro firmemente, e isto eu vejo como um fundamento suficiente para a religião." 


\section{\#arte VI}

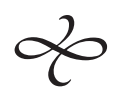

1. "Há de ser uma estrutura tênue, de fato," disse DêMEAS, "a que se pode erigir sobre um fundamento tão cambaleante. Enquanto estivermos incertos de se há uma Deidade ou várias, se a Deidade ou as Deidades a quem devemos nossa existência são perfeitas ou imperfeitas, subordinadas ou supremas, mortas ou vivas, que crédito ou confiança podemos depositar nelas? Que devoção ou adoração podemos lhes endereçar? Que veneração ou obediência podemos ter por elas? Para todos os propósitos da vida, a teoria da religião se torna completamente inútil - e, mesmo para as consequências especulativas, sua incerteza, de acordo contigo, há de torná-la totalmente precária e insatisfatória."

2. "Para torná-la ainda mais insatisfatória", disse FILÃo, "ocorre-me uma outra hipótese que tem que adquirir um ar de probabilidade a partir do método de raciocínio em que CLEANTES insiste tanto. Efeitos semelhantes surgem de causas semelhantes: este 
princípio ele supõe ser o fundamento da religião. Mas há outro princípio do mesmo tipo, não menos certo e derivado da mesma fonte de experiência: Onde se observa que várias circunstâncias conhecidas são similares, descobrir-se-á que a desconhecida também é similar. Assim, se virmos os membros dum corpo humano, concluímos que eles também são acompanhados por uma cabeça humana, embora escondida de nós. Assim, se virmos através duma fenda na parede uma pequena parte do sol, concluímos que, fosse a parede removida, veríamos todo o corpo. Em poucas palavras: este método de raciocínio é tão óbvio e familiar que não podemos ter nenhuma hesitação a respeito de sua solidez.

3. "Ora, se examinarmos o universo, ele tem, até onde o conheçamos, uma grande semelhança com um corpo animal organizado, e parece movido por um princípio semelhante a vida e movimento. Uma circulação contínua de matéria nele não produz desordem alguma, um desgaste contínuo em cada parte é incessantemente reparado, percebe-se a concórdia ${ }^{19}$ mais minuciosa através do sistema inteiro, e cada parte ou membro, ao desenvolver seu ofício próprio, opera tanto pela sua própria preservação quanto pela do todo. O mundo portanto, infiro eu, é um animal, e a Deidade é a ALMA do mundo, movendo-o e sendo movida por ele. ${ }^{20}$

4. "Tens estudo demais, CleANTES, para te surpreenderes com esta opinião que, tu o sabes, foi sustentada por quase todos os

19 No original, "symapthy". Claro está que "sympathy" não pode ser "simpatia", então buscamos o significado que ela teria em clássicos, e felizmente acontece de Cícero (ND, III, 28) tê-la vertido para o latim: ele alude a "iste quasi consen-

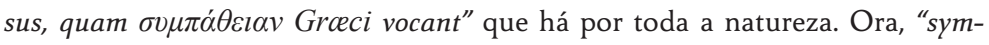
pathia" para Cícero virou "consensus", que é etimologicamente bom, mas cujo sentido, alterado com o tempo, torna "consenso" uma tradução inviável. Então usei a solução de Rackham de verter "consensus" por "concord", i.e., "concórdia".

20 Cf. ND, I, 37: "Cleanthes [...] tum ipsum mundum deum dicit esse, tum totius naturce menti atque animo tribuit hoc nomen [...]." Em português: "Cleantes [...] ora diz que o próprio mundo é Deus, ora dá este nome à mente e alma de toda a natureza [...]." Cleantes de Assos era um filósofo estoico. 
teístas da antiguidade e prevalece ao máximo em seus discursos e raciocínios. Pois embora algumas vezes os filósofos antigos raciocinem a partir de causas finais, como se pensassem ser o mundo obra de Deus, parece antes que sua noção favorita é considerá-lo seu corpo, cuja organização o torna subserviente a ele. E deve-se confessar que o universo se assemelha mais a um corpo humano do que aos trabalhos de arte e engenho humanos. Se nossa analogia limitada puder, com alguma propriedade, ser estendida para a inteireza da natureza, a inferência parece mais exata a favor da teoria antiga do que da moderna.

5. "Há também muitas outras vantagens nessa teoria que a recomendaram aos teólogos antigos. Nada é mais repugnante a todas as suas noções, porque nada é mais repugnante à experiência comum, do que mente sem corpo $^{21}$ : uma substância meramente espiritual que nunca esteve sob os seus sentidos nem sua compreensão, e da qual não observaram um único exemplo através de toda a natureza. Mente e corpo eles conheceram, pois sentiram ambos; uma ordem, arranjo ou maquinaria interna em ambos também conheceram da mesma maneira - e não poderia deixar de parecer razoável transferir esta experiência para o universo e supor que a mente e o corpo divinos são também coevos e têm, ambos, ordem e arranjo que lhes são naturalmente inerentes e inseparáveis.

6. "Aqui portanto está uma nova espécie de antropomorfismo, ClEANTES, sobre a qual podes deliberar, e uma teoria que não parece propensa a dificuldades consideráveis. És com certeza superior demais a preconceitos de sistema para encontrar alguma dificuldade a mais em supor que o corpo animal seja originariamente, por si só ou por causas desconhecidas, dotado de ordem e organização do que em supor que uma ordem similar pertença à mente. Mas o preconceito vulgar de que corpo e mente têm de estar sempre juntos não deve, poder-se-ia pensar, ser inteiramen-

21 Cf. ND, I, 33. 
te negligenciado, uma vez que se funda na experiência vulgar - o único guia que professas seguir em todas essas investigações teológicas. E se asserires que nossa experiência limitada é um critério desigual para julgar acerca da extensão ilimitada da natureza, abandonarás inteiramente tua própria hipótese e terás a partir de então que adotar nosso misticismo (como o chamas) e admitir a incompreensibilidade absoluta da natureza divina."

7. "Esta teoria, admito," replicou Cleantes, "nunca me ocorrera antes, embora seja bem natural, e não posso prontamente, sobre um exame e reflexão tão curtos, proferir alguma opinião a seu respeito." "És muito escrupuloso, de fato", disse FILÃo, "Fosse eu examinar qualquer sistema teu, não teria agido com metade deste cuidado e reserva em levantar-lhe objeções e dúvidas. No entanto, se alguma coisa te ocorrer, nos obsequiarás propondo-a."

8. "Pois bem," disse Cleantes, "parece-me que, embora o mundo se assemelhe em muitas circunstâncias a um corpo animal, esta analogia ainda é defectiva em muitas circunstâncias das mais cruciais: sem órgão de sentido, sem sede de pensamento ou razão, nenhuma origem precisa de movimento ou ação. Em poucas palavras, ele parece sustentar uma semelhança maior com um vegetal do que com um animal, e tua inferência seria até agora inconclusiva a favor da alma do mundo.

9. "Ademais, tua teoria parece implicar a eternidade do mundo, e este é um princípio que, penso eu, pode ser refutado pelas razões e probabilidades mais fortes. Hei de sugerir um argumento a este propósito em que, creio, nunca autor algum insistiu. Aqueles que raciocinam sobre a origem tardia das artes e ciências, embora à sua inferência não falte força, podem talvez ser refutados por considerações derivadas da natureza da sociedade humana, que está em revolução contínua entre ignorância e conhecimento, liberdade e escravidão, riqueza e pobreza, de modo que nos é impossível, a partir de nossa experiência limitada, predizer com segurança quais eventos podem ou não podem ser 
esperados. A erudição e a história antigas parecem ter estado em grande perigo de perecer inteiramente depois da invasão das nações bárbaras; e tivessem essas convulsões durado um pouco mais ou sido um pouco mais violentas, provavelmente não saberíamos agora o que se passou no mundo uns poucos séculos antes de nós. Mais ainda: não fosse a superstição dos papas, que preservaram um pequeno jargão do LATIM para manterem a aparência duma igreja antiga e universal, essa língua deveria ter sido completamente perdida: neste caso o Ocidente, sendo totalmente bárbaro, não teria estado numa disposição adequada para receber a língua e a erudição GREGAS às quais teve acesso depois de saquear Constantinopla. Se a erudição e os livros tivessem sido extintos, mesmo as artes mecânicas decairiam consideravelmente; e pode-se imaginar facilmente que fábulas ou tradição poderiam imputar-lhes uma origem muito mais tardia do que verdadeira. Este argumento vulgar, portanto, contra a eternidade do mundo, parece um pouco precário.

10. "Mas aqui parece estar o fundamento dum argumento melhor: LUCULO foi o primeiro que trouxe cerejeiras da ÁsIA para a EUROPA, embora esta árvore floresça tão bem em climas EUROPEUS e cresça nos bosques sem qualquer cultivo. Será possível que, através duma eternidade inteira, nenhum EUROPEU tenha passado pela Ásı e pensado em transplantar um fruto tão delicioso para seu próprio país? Ou se a árvore foi uma vez transplantada e propagada, como poderia perecer depois? Impérios podem ascender e cair, liberdade e escravidão se sucederem alternadamente, ignorância e conhecimento darem lugar uma ao outro - mas a cerejeira ainda remanescerá nos bosques da GRÉCIA, da EsPANHA e da ITÁLIA, e nunca será afetada pelas revoluções da sociedade humana.

11. "Não faz dois mil anos que vinhas foram transplantadas para a FRANÇA, embora não haja clima no mundo mais favorável a elas. Não faz três séculos que cavalos, vacas, ovelhas, suínos, cães, grãos, são conhecidos na AMÉRICA. É possível que, durante as revo- 
luções duma eternidade inteira, nunca tenha surgido um Colombo que pudesse abrir a comunicação entre a EUROPA e esse continente? Podemos imaginar isto tão bem quanto que todos os homens usaram meias por dez mil anos e jamais tiveram o senso de pensar em ligas para atá-las. Todas estas parecem provas convincentes da juventude ou antes infância do mundo, já que se fundam na operação de princípios mais constantes e firmes do que aqueles sobre os quais a sociedade humana é governada e dirigida. Nada menos do que uma convulsão total dos elementos destruirá todos os animais e vegetais EUROPEUS que se acham no Ocidente."

12. "E que argumentos tens contra tais convulsões?", perguntou FILÃo. "É possível remontar a provas fortes e quase incontestáveis sobre toda a terra de que cada parte deste globo permaneceu por muitas eras inteiramente coberta por água. E mesmo que a ordem fosse suposta como inseparável da matéria e inerente a esta, ainda assim a matéria pode ser suscetível a muitas e grandes revoluções através dos períodos infindáveis de duração eterna. As mudanças incessantes, às quais cada parte sua está sujeita, parecem anunciar algumas tais transformações gerais; embora ao mesmo tempo seja observável que todas as mudanças e corrupções das quais sempre tivemos experiência sejam apenas passagens de um estado de ordem para outro, e tampouco possa a matéria permanecer para sempre em deformidade e confusão totais. $\mathrm{O}$ que vemos nas partes podemos inferir no todo - ao menos este é o método de raciocínio sobre o qual fundas toda a tua teoria. E fosse eu obrigado a defender qualquer sistema particular dessa natureza (o que eu jamais faria voluntariamente), não estimo nenhum mais plausível do que aquele que atribui ao mundo um princípio de ordem eterno, inerente, embora acompanhado por revoluções e alterações contínuas e grandes. Isto solve duma vez todas as dificuldades; e se a solução, por ser tão geral, não é inteiramente completa e satisfatória, é ao menos uma teoria à qual mais cedo ou mais tarde hemos de ter 
recurso, qualquer que seja o sistema que abracemos. Como as coisas poderiam ter sido como são, não houvesse um princípio de ordem original, inerente, nalgum lugar, no pensamento ou na matéria? E é bem indiferente a qual desses damos a preferência. $\mathrm{O}$ acaso não tem lugar em hipótese alguma, cética ou religiosa. Tudo é, seguramente, governado por leis firmes, invioláveis; e fosse-nos exposta a essência mais recôndita das coisas, descobriríamos então um cenário do qual agora não podemos ter ideia. Ao invés de admirarmos a ordem dos seres naturais, deveríamos ver claramente que lhes era absolutamente impossível, até no menor artigo, admitir qualquer outra disposição.

13. "Fosse alguém inclinado a reviver a antiga Teologia Pagã, que manteve, como aprendemos por Hesíodo, que este globo era governado por 30.000 Deidades que surgiram dos poderes desconhecidos da natureza, poderias objetar naturalmente, CLEANTES, que nada se ganha com esta hipótese; e que é tão fácil quanto supor que todos os homens e animais, seres mais numerosos mas menos perfeitos, surgiram todos imediatamente duma origem parecida. Empurra a mesma inferência para mais um passo adiante e acharás uma sociedade de Deidades numerosa tão explicável quanto uma Deidade universal que possui nela mesma os poderes e perfeições da sociedade inteira. Todos esses sistemas, pois, de ceticismo, politeísmo e teísmo, deves admiti-lo, com base nos teus princípios estão em pé de igualdade, e nenhum deles tem qualquer vantagem sobre os outros. Podes daí tomar conhecimento da falácia de teus princípios." 


\section{円arte VII}

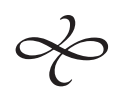

1. "Mas aqui", continuou FILÃo, "ao examinar o antigo sistema da alma do mundo, arrebata-me de repente uma nova ideia que, se justa, deve aproximar-se de subverter todo o teu raciocínio e destruir mesmo as tuas primeiras inferências, nas quais depositas tanta confiança. Se o universo sustenta uma semelhança maior com os corpos animais e vegetais do que com os trabalhos de arte humana, é mais provável que sua causa se assemelhe mais à dos primeiros do que às dos segundos, e sua origem deve ser atribuída antes à geração ou à vegetação do que à razão ou ao desígnio. Tua conclusão, mesmo de acordo com teus próprios princípios, é portanto frouxa e defeituosa."

2. "Rogo que explanes sobre este argumento um pouco mais" disse DÊMEAS, "Pois eu não o apreendo direito nesta maneira concisa em que o expressaste." 
3. "Nosso amigo Cleantes," replicou Filão, "como ouviste, assere que porquanto nenhuma questão de fato pode ser provada doutra maneira que não pela experiência, a existência da Deidade não admite provas advindas doutro meio. $\mathrm{O}$ mundo, diz ele, se parece com os trabalhos de engenho humano; portanto, sua causa também deve se parecer com a destes. Aqui podemos notar que a operação duma parte bem pequena da natureza, a saber, o homem, sobre uma outra parte bem pequena, a saber, a matéria inanimada que jaz sob seu alcance, é a regra pela qual Cleantes julga a origem do todo; e ele mensura objetos tão vastamente desproporcionais pelo mesmo padrão individual. Mas para pôr de lado todas as objeções extraídas deste tópico, afirmo que há outras partes do universo (além de máquinas de invenção humana) que sustentam uma semelhança maior ainda com estrutura do mundo e que portanto fornecem uma conjectura melhor sobre a origem universal deste sistema. Estas partes são animais e vegetais. $\mathrm{O}$ mundo claramente se assemelha mais a um animal ou a um vegetal do que a um relógio ou a um tear. Sua causa, portanto, é mais provável que se assemelhe à causa dos primeiros. A causa dos primeiros é geração ou vegetação. A causa do mundo, portanto, podemos inferir ser alguma coisa similar ou análoga a geração ou vegetação."

4. "Mas como é concebível", disse DÊMEAS, "que o mundo possa surgir dalguma coisa similar a vegetação ou geração?"

5. "Muito facilmente", replicou FILÃo. "Assim como uma árvore espalha suas sementes pelos campos vizinhos e produz outras árvores, o grande vegetal, o mundo ou este sistema planetário, produz em si mesmo certas sementes que, sendo dispersadas pelo caos à volta, tornam-se por vegetação novos mundos. Um cometa, por exemplo, é a semente dum mundo, e depois de ela ter amadurecido ao passar de sol a sol e de estrela a estrela, é por fim lançada aos elementos informes que rodeiam este universo por toda parte e, tão logo brote, torna-se um novo sistema. 
6. "Ou se, por conta da variedade (pois não vejo outra vantagem) houvéssemos de supor que este mundo é um animal, o cometa seria o ovo deste animal, e assim como a avestruz deixa seu ovo na areia que, sem qualquer outro cuidado, aninha o ovo e produz um novo animal, o..."

7. "Eu te entendo," diz DÊMEAS, "mas que suposições extravagantes, arbitrárias são estas? Que dados tens para conclusões tão extraordinárias? E acaso a semelhança tênue, imaginária do mundo com um vegetal ou com um animal é suficiente para estabelecer a mesma inferência a respeito de ambos? Objetos que são em geral tão vastamente diferentes podem ser padrão uns para os outros?"

8. "Certo!", bradou FILÃo, "Este é o tópico sobre o qual venho insistindo durante todo o tempo. Eu ainda afirmei que não temos dados para estabelecer qualquer sistema de cosmogonia. Nossa experiência, tão importante em si mesma e tão limitada tanto em sua extensão quanto em sua duração, não pode nos fornecer nenhuma conjectura provável sobre o todo das coisas. Mas se tivermos necessariamente que nos fixar nalguma hipótese, por que regra, rogo que se responda, deveremos determinar nossa escolha? Há alguma outra regra que não a maior similaridade dos objetos comparados? E uma planta ou um animal, que surgem de vegetação ou geração, sustentam uma semelhança mais forte com o mundo do que qualquer máquina artificial que surge de razão e desígnio?"

9. “Mas o que é essa vegetação e geração de que falas?" disse DÊMEAS. "Podes explicar suas operações e anatomizar essa estrutura interna fina das quais elas dependem?"

10. "Pelo menos tão bem", replicou Filão, "quanto Cleantes pode explicar as operações da razão ou anatomizar essa estrutura interna da qual ela depende. Mas, sem quaisquer disquisições elaboradas, quando vejo um animal infiro que ele surgiu de geração; e isso com uma grande certeza tão grande quanto a com que 
concluis que uma casa foi erguida por desígnio. Estas palavras - 'geração', 'razão' - marcam apenas certos poderes e energias na natureza cujos efeitos são conhecidos, mas cuja essência é incompreensível; e um desses princípios, mais do que nenhum outro, não tem privilégio nenhum para que seja feito dele um padrão para o todo da natureza.

11. "Na realidade, DÊMEAS, pode-se razoavelmente esperar que, quanto mais largas as vistas que tomamos das coisas, melhor elas nos conduzam em nossas conclusões concernentes a assuntos tão extraordinários e tão magníficos. Apenas neste canto estreito do mundo há quatro princípios - razão, instinto, geração, vegetação, - que são similares uns aos outros e são as causas de efeitos similares. Que número doutros princípios poderíamos supor naturalmente na imensa extensão e variedade do universo, se pudéssemos viajar de planeta a planeta e de sistema a sistema a fim de examinar cada parte desta estrutura imensa? Qualquer um desses quatro princípios acima mencionados (e uma centena que está aberta para a nossa conjectura) pode nos fornecer uma teoria pela qual se julgue a origem do mundo, e é uma parcialidade palpável e egrégia confinar nossas vistas inteiramente a este princípio sobre o qual nossas próprias mentes operam. Fosse este princípio mais inteligível por essa explicação, tal parcialidade seria algo desculpável - mas a razão, em sua estrutura interna, nos é realmente tão desconhecida quanto instinto ou vegetação, e talvez mesmo essa palavra vaga, indeterminada, 'natureza', à qual o vulgo refere tudo, não seja no fundo mais inexplicável. Os efeitos desses princípios nos são conhecidos pela experiência - mas os próprios princípios e suas maneiras de operação são totalmente desconhecidos, e tampouco é menos inteligível ou menos conforme à experiência dizer que o mundo surgiu por vegetação advindo duma semente lançada por outro mundo do que dizer que ele surgiu duma razão ou engenho divinos, de acordo com o sentido em que CleANTES entende." 
12. "Mas me parece", disse DÊMEAs, "que se o mundo tivesse uma qualidade vegetativa e pudesse semear as sementes de novos mundos pelo caos infinito, esse poder seria ainda um argumento adicional para desígnio em seu Autor. Pois donde poderia surgir uma faculdade tão maravilhosa senão de desígnio? Ou como pode a ordem surgir dalguma coisa que não perceba a ordem que confere?"

13. "Precisas apenas olhar à tua volta", replicou FILÃO, "para te satisfazeres quanto a esta questão. Uma árvore confere ordem e organização à árvore que surge dela sem conhecer a ordem; um animal, da mesma maneira, à sua cria; um pássaro ao seu ninho e exemplos deste tipo são ainda mais frequentes neste mundo do que aqueles de ordem que procedem de razão e engenho. Dizer que toda essa ordem em animais e vegetais procede em última instância de desígnio é petição de princípio, e tampouco se pode asserir esse grande ponto doutro modo que não provando a priori tanto que a ordem é por sua natureza inseparavelmente ligada ao pensamento quanto que ela nunca pode por si própria ou por princípios originais desconhecidos pertencer à matéria.

14. "Mas mais ainda, DÊMEAS, esta objeção que incitas nunca pode ser usada por CLEANTES sem renunciar a uma defesa que ele já fez contra uma das minhas objeções. Quando perguntei sobre a causa dessa razão e inteligência supremas nas quais ele resolve todas as coisas, ele me contou que a impossibilidade de satisfazer tais perguntas nunca poderia ser admitida como uma objeção em qualquer espécie de filosofia. 'Temos de parar algures', diz ele, 'e jamais estará ao alcance da capacidade humana explicar as causas últimas ou mostrar as últimas conexões de quaisquer objetos. Será suficiente se os passos, até onde avancemos, forem sustentados por experiência e observação.' Ora, que se tenha a experiência de a vegetação e a geração, tanto quanto a razão, serem princípios de ordem, é inegável. Se eu sustentar meu sistema de cosmogonia pela primeira preferivelmente à última, isto está 
à minha escolha. A questão parece inteiramente arbitrária. E se Cleantes me perguntar qual é a causa do meu grande sistema vegetativo ou gerativo, tenho igual direito de lhe perguntar pela causa desse grande princípio raciocinativo. Ambos os lados já concordamos em nos abster destas questões, e na presente ocasião é sobretudo dele o interesse de se agarrar a este acordo. A julgar pela nossa experiência imperfeita e limitada, a geração tem alguns privilégios sobre a razão - pois vemos todo dia a última surgir da primeira, nunca a primeira da última.

15. "Compara, rogo a ti, as consequências em ambos os lados. O mundo, digo eu, se assemelha a um animal, portanto é um animal, portanto surgiu de geração. Os passos, confesso, são largos; mas ainda há alguma aparência de analogia em cada passo. O mundo, diz CleANTES, se assemelha a uma máquina, portanto é uma máquina, portanto surgiu de desígnio. Os passos aqui são igualmente largos; e a analogia, menos arrebatadora. E se ele pretende levar minha hipótese para um passo mais adiante, e inferir desígnio ou razão a partir do grande princípio de geração no qual insisto, eu posso, com autoridade melhor, usar da mesma liberdade para levar mais adiante sua hipótese e inferir uma geração divina ou teogonia a partir de seu princípio de razão. Eu tenho pelo menos uma tênue sombra de experiência, o que é o mais extremo que se pode alcançar no presente assunto: Observa-se que a razão, em inumeráveis exemplos, surge do princípio de geração, e que nunca surge de qualquer outro princípio.

16. "Hesíodo e todos os mitólogos antigos foram tão arrebatados por esta analogia que universalmente explicaram a origem da natureza a partir dum nascimento animal e cópula. Platão também, na medida em que ele é inteligível, parece ter adotado tal noção no seu Timeu.

$17 .^{22}$ "Os BRÂMANES asserem que o mundo surgiu duma aranha infinita que teceu de suas entranhas esta massa complicada,

22 Este parágrafo foi acrescentado entre 1751 e 1763. 
e aniquila depois o todo ou cada parte dela absorvendo-a de novo e decompondo-a em sua própria essência. Aqui está uma espécie de cosmogonia que nos parece ridícula, porque uma aranha é um animal algo vil cujas operações somos propensos a nunca tomar como modelo para o universo inteiro. Mas ainda aqui há uma nova espécie de analogia, mesmo no nosso globo. E houvesse um planeta inteiramente habitado por aranhas (o que é bem possível), esta inferência pareceria lá tão natural e irrefragável quanto esta que em nosso planeta atribui a origem de todas as coisas a desígnio e inteligência, como Cleantes explica. Por que um sistema ordeiro não pode ser tecido pela barriga tão bem como pelo cérebro será difícil para ele dar uma razão satisfatória."

18. "Devo confessar, Filão," replicou Cleantes, "que, de todos os homens viventes, a tarefa que empreendeste, de levantar dúvidas e objeções, te convém ao máximo e parece, de certo modo, natural e inevitável para ti. Tão grande é a fertilidade de tua invenção, que não me envergonho por me reconhecer incapaz, de supetão, de resolver regularmente dificuldades tão remotas como as que sem cessar levantas contra mim - embora eu veja com clareza, no geral, sua falácia e erro. E não questiono, mas tu próprio ora estás na mesma situação, e não tens uma solução tão fácil quanto a objeção, ao passo que tens de saber que o senso comum e a razão estão inteiramente contra ti e que tais extravagâncias como as que proferiste podem confundir, mas nunca nos convencer." 


\section{\#arte VIII $\alpha$}

1. "O que atribuis à fertilidade de minha invenção", replicou FILÃO, "se deve inteiramente à natureza do assunto. Em assuntos apropriados para o âmbito estreito da razão humana, é comum haver apenas uma determinação dotada de probabilidade ou convicção, e a um homem de juízo são, todas as outras suposições que não aquela parecem de todo absurdas e quiméricas. Mas em questões tais como a presente, uma centena de visões contraditórias pode preservar um tipo de analogia imperfeita, e a invenção tem aqui pleno alcance para atuar. Sem qualquer grande esforço de pensamento, creio que pude num instante propor outros sistemas de cosmogonia que teriam alguma tênue aparência de verdade, embora seja de mil, de um milhão para um, se o teu ou algum dos meus for o verdadeiro sistema.

2. "Por exemplo: e se eu quiser reviver a velha hipótese EPICURISTA? É comumente e, creio, com justeza, estimado o sistema 
mais absurdo jamais proposto; ainda assim, não sei se com poucas alterações ele não pode ser trazido para uma tênue aparência de probabilidade. Ao invés de supor a matéria infinita, como EpICURO fez, suponhamo-la finita. Um número finito de partículas é suscetível apenas a transposições finitas; e tem de acontecer, numa duração eterna, que cada ordem ou posição possíveis sejam tentadas num número infinito de vezes. Este mundo, portanto, com todos os seus eventos, mesmo os mais diminutos, foi antes produzido e destruído, e será novamente produzido e destruído sem quaisquer impedimentos ou limitações. Ninguém que tenha uma concepção dos poderes do infinito em comparação ao finito jamais terá escrúpulos para esta determinação."

3. "Mas isto supõe", disse DÊMEAs, "que a matéria pode adquirir movimento sem qualquer agente ou motor voluntários."

4. "E onde está a dificuldade", replicou FILÃo, "desta suposição? Todo evento antes da experiência é igualmente difícil e incompreensível, e cada evento depois da experiência é igualmente fácil e inteligível. O movimento, em vários exemplos - pela gravidade, pela elasticidade, pela eletricidade -, começa na matéria sem qualquer agente voluntário conhecido, e supor sempre nestes casos um agente voluntário desconhecido é mera hipótese, e hipótese acompanhada de nenhuma vantagem. O começo do movimento na própria matéria é a priori tão concebível quanto sua comunicação por mente e inteligência.

5. "Ademais, por que o movimento não poderá ter se propagado por impulso através de toda a eternidade e o mesmo estoque, ou quase o mesmo, se preservado ainda no universo? Tanto quanto é perdido pela composição do movimento é ganho pela sua decomposição. E quaisquer que sejam as causas, o fato é certo: a matéria sempre está e sempre esteve em agitação contínua até onde a experiência ou tradição humanas alcançam. Provavelmente agora não há no universo inteiro uma única partícula de matéria em repouso absoluto. 
6. "E também essa própria consideração," continuou FILÃO, "com a qual nos esbarramos no curso do argumento, sugere uma nova espécie de cosmogonia que não é absolutamente absurda e improvável. Haverá um sistema, uma ordem, uma economia de coisas pela qual a matéria possa preservar essa agitação perpétua que lhe parece essencial e ainda mantenha uma constância nas formas que produz? Decerto há tal economia, pois este de fato é o caso do mundo presente. O movimento contínuo da matéria, portanto, em transposições menos do que infinitas, tem que produzir esta economia ou ordem, e por sua própria natureza essa ordem, quando uma vez estabelecida, sustenta a si própria por muitas eras, se não pela eternidade. Mas onde quer que a matéria seja equilibrada, arranjada e ajustada assim, de modo a continuar em movimento e ainda preservar constância em suas formas, sua situação tem necessariamente que ter a mesmíssima aparência de arte e engenho que ora observamos. Todas as partes de cada forma têm de ter uma relação com cada outra e com o todo - e o próprio todo tem de ter uma relação com as outras partes do universo: com o elemento em cuja forma subsiste, com os materiais com os quais repara sua perda e deterioração, e com toda outra forma à qual é hostil ou amigável. Um defeito em quaisquer desses particulares destrói a forma, e a matéria da qual ela era composta é novamente solta e lançada em movimentos e fermentações irregulares até unir se novamente nalguma outra forma regular. Se nenhuma forma tal puder se preparar para recebê-la, e se houver uma grande quantidade dessa matéria corrupta no universo, o próprio universo fica inteiramente desordenado: quer seja o embrião frágil de um mundo em seus primeiros começos, quer seja uma carcaça podre de um mundo se debilitando na velhice e na doença, destrói-se desse modo. Em ambos os casos, segue-se um caos até que revoluções finitas porém inumeráveis produzam ao cabo algumas formas cujas partes 
e órgãos sejam ajustados de modo a sustentarem-nas em meio a uma sucessão contínua de matéria.

7. ${ }^{23}$ "Supõe (pois devemos tentar variar a expressão) que a matéria seja lançada em qualquer posição por uma força cega, sem guia: é evidente que esta primeira posição deve ser, com toda probabilidade, a mais confusa e desordeira que se possa imaginar, desprovida de qualquer semelhança com trabalhos do engenho humano, que encontra, com a simetria das partes, um ajuste de meios a fins e uma tendência à autopreservação. Se a força atuante cessar depois dessa operação, a matéria haverá de permanecer para sempre em desordem e continuar num caos imenso, sem proporção ou atividade. Mas supõe que a força atuante, qualquer que seja, ainda continue na matéria: essa primeira posição imediatamente dará lugar a uma segunda, que com toda probabilidade será tão desordeira quanto a primeira, e assim por diante, através de muitas sucessões de mudanças e revoluções. Nenhuma ordem ou posição particular jamais permanece por um momento inalterada. A força original, ainda permanecendo em atividade, dá uma incansabilidade perpétua à matéria. Toda situação possível é produzida e instantaneamente destruída. Se um vislumbre ou raiar de ordem aparece por um momento, é instantaneamente tragado para longe e confundido por essa força incessante que move cada parte da matéria.

8. "Assim o universo prosseguirá por muitas eras numa sucessão contínua de caos e desordem. Mas não é possível que ele se estabeleça por fim, de modo não a perder seu movimento e força ativa (pois a supusemos inerente a ele), mas a preservar uma uniformidade de aparência em meio ao movimento e flutuação contínuos de suas partes? Isto descobrimos ser o caso no universo agora: cada individuo está mudando perpetuamente, e toda parte de todo indivíduo, e o todo, em sua aparência, ainda permanece o mesmo. Não poderemos esperar tal posição, ou

23 Este parágrafo e o próximo foram acrescentados entre 1751 e 1763. 
antes nos assegurar dela, a partir das revoluções eternas da matéria sem guia?, e isto não poderá dar conta de toda a sabedoria e engenho aparentes que estão no universo? Contemplemos o assunto um pouco e havemos de descobrir que esse ajuste de estabilidade aparente nas formas, se alcançado pela matéria com uma revolução de movimento real e perpétua das partes, fornece para a dificuldade uma solução possível, se não verdadeira.

9. "É vão, portanto, insistir nos usos das partes em animais e vegetais, e no seu curioso ajuste mútuo. Eu gostaria de saber como um animal poderia subsistir se suas partes não fossem bem ajustadas. Não descobrimos que ele perece imediatamente sempre que esse ajuste cessa e que sua matéria ao corromper-se tenta uma nova forma? Acontece, de fato, que as partes do mundo são tão bem ajustadas, que alguma forma regular reivindica imediatamente essa matéria corrompida. E se não fosse assim, o mundo poderia subsistir? Não teria que se dissolver tanto quanto um animal e passar por novas posições e situações, até por uma sucessão grande porém finita cair enfim na presente ordem ou nalguma outra?"24

10. "Ainda bem que", disse Cleantes, "como nos disseste, esta hipótese foi sugerida de repente, no curso do argumento. Tivesses tido vagar para examiná-la, terias percebido logo as objeções insuperáveis às quais ela está exposta. Nenhuma forma, dizes, pode subsistir, a menos que possua aqueles poderes e órgãos necessários para a sua subsistência. Alguma nova ordem ou economia deve ser tentada daí em diante, sem qualquer intervalo, até

24 Cf. RN, V, 849-859: "Vemos efetivamente que deve existir um concurso de circunstâncias para que seja possível às gerações o propagar-se; é necessário primeiro que haja alimentos e depois que exista para os elementos seminais uma saída por onde possam correr dos membros cansados; para que a fêmea se possa juntar aos machos, é preciso que tenha cada um o que permita a troca de gozos. Tiveram então que desaparecer muitas raças de seres vivos que não puderam, reproduzindo-se, dar origem a uma descendência. Todas aquelas que vês se alimentarem das auras vitais têm, ou a manha, ou a força, ou então a mobilidade que, desde o princípio, protegeram a raça e a conservaram." 
que surja ao cabo alguma ordem que possa se sustentar e manter. Mas, de acordo com esta hipótese, donde surgem as muitas conveniências e vantagens que os homens e todos os animais possuem? Dois olhos, dois ouvidos não são absolutamente necessários para a subsistência da espécie. A raça humana poderia ser propagada e preservada sem cavalos, cães, vacas, ovelhas e esses inumeráveis frutos e produtos que servem à nossa satisfação e diversão. Se nenhum camelo fosse criado para o uso do homem nos desertos arenosos da África e ArÁbIA, o mundo teria sido dissolvido? Se nenhum ímã tivesse sido forjado para dar à agulha essa direção maravilhosa e útil, a sociedade e o gênero humanos teriam sido imediatamente extintos? Embora as máximas da natureza sejam no geral bem frugais, exemplos desse tipo ainda estão longe de ser raros, e qualquer um deles é prova suficiente de desígnio, e dum desígnio benevolente que deu origem à ordem e arranjo do universo."

11. "Ao menos podes inferir com segurança", disse FiLÃo, "que a hipótese anterior está até agora incompleta e imperfeita, o que não devo ter escrúpulos em admitir. Mas acaso podemos, com razoabilidade, esperar sucesso maior nalguma tentativa desta natureza? Ou podemos acaso esperar erigir um sistema de cosmogonia que não será propenso a nenhuma exceção e não conterá nenhuma circunstância repugnante à nossa experiência imperfeita e limitada da analogia da natureza? Tua própria teoria não pode pretender ter com segurança qualquer vantagem - mesmo que tenhas corrido para o antropomorfismo, o melhor para preservar uma conformidade à experiência comum. Então levemos mais uma vez a julgamento isto: 'Em todos os exemplos que vimos, ideias são copiadas de objetos reais; e são éctipos ${ }^{25}$, não

25 Tive de usar este termo não dicionarizado para traduzir "ectypal", termo muito usado por Locke no Ensaio sobre o entendimento humano para referir-se às ideias. É, por assim dizer, antônimo de "arquétipo": enquanto "arkhê" é "origem" em grego, a preposição " $e k$ " marca procedência. Assim, enquanto um é o "tipo originário"; o outro, o "tipo procedente". 
arquétipos', para expressar-me em termos eruditos. Invertes esta ordem e dás ao pensamento a precedência. Em todos os exemplos que já vimos, o pensamento não tem nenhuma influência sobre a matéria, exceto quando esta lhe é conjugada de modo a ter uma influência igual recíproca sobre aquele. Nenhum animal pode mover imediatamente outra coisa que não os membros do seu próprio corpo; e, de fato, a igualdade entre ação e reação parece ser uma lei universal da natureza. Mas a tua teoria implica uma contradição a esta experiência. Tais exemplos, juntos a muitos outros que são facilmente coletados (particularmente a suposição duma mente ou sistema de pensamento que é eterno ou, noutras palavras, um animal inengendrável e imortal), estes exemplos, digo, podem nos ensinar a todos nós a sobriedade ao condenarmos um ao outro, e nos deixam ver que, como nenhum sistema deste tipo jamais deve ser recebido duma analogia tênue, tampouco deve ser rejeitado por ter uma pequena incongruência. Pois esta é uma inconveniência da qual, podemos com justeza declarar, ninguém está isento.

12. "Todos os sistemas religiosos, confessa-se, estão sujeitos a dificuldades grandes e insuperáveis. Cada disputante triunfa a seu turno, quando leva adiante uma guerra ofensiva e expõe os absurdos, barbaridades e preceitos perniciosos do antagonista. Mas todos eles, em conjunto, preparam um triunfo completo para o cético, que lhes diz que não se deve abraçar nenhum sistema a respeito desses assuntos, por esta razão simples: não se deve jamais assentir a absurdo algum a respeito de qualquer assunto. Uma suspensão total de juízo é aqui o nosso único recurso razoável. E se todo ataque, como comumente se observa, e nenhuma defesa entre teólogos tem sucesso, o quão completa não tem que ser a vitória daquele, que permanece sempre, com toda a humanidade, na ofensiva, e que não tem ele próprio um posto fixo ou cidade em que more, a que esteja sempre, em qualquer ocasião, obrigado a defender?" 


\section{\#arte IX}

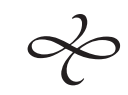

1. "Mas se dificuldades tão grandes acompanham o argumento a posteriori", disse DÊMEAS, "não seria melhor aderirmos a esse simples e sublime argumento a priori que, oferecendo-nos demonstração infalível, exclui duma vez toda dúvida e dificuldade? Por este argumento também podemos provar a INFINITUDE dos atributos divinos que, receio, nunca pode ser asserido com certeza a partir de qualquer outro tópico. Pois como pode um efeito que ou bem é finito ou bem, pelo que devemos saber, pode sê-lo; como pode tal efeito, digo, provar uma causa infinita? Também a unidade da natureza divina é bem difícil, se não impossível, deduzir-se meramente a partir da contemplação dos trabalhos da natureza; e tampouco a tão-só uniformidade do plano, mesmo quando concedida, nos dará qualquer segurança desse atributo. Ao passo que o argumento a priori..." 
2. "Pareces raciocinar, Dêmeas," interpôs Cleantes, "como se as vantagens e conveniências do argumento abstrato fossem provas plenas de sua solidez. Mas em primeiro lugar é apropriado, em minha opinião, determinar em qual argumento dessa natureza escolhes insistir, e em seguida, mais pelo próprio do que pelas suas consequências úteis, havemos de tentar determinar que crédito lhe devemos dar."

3. "O argumento", replicou DêMEAs, "no qual eu insistiria é o comum. O que quer que exista tem que ter uma causa ou razão de sua existência, sendo impossível para qualquer coisa produzirse a si mesma ou ser a causa de sua própria existência. Remontando, portanto, de efeitos a causas, devemos ou bem continuar até uma sucessão infinita, sem nenhuma causa última, ou bem devemos por fim ter recurso a alguma causa última, que é necessariamente existente. Ora, que a primeira suposição é absurda deve-se provar assim: Na cadeia ou sucessão infinita de causas e efeitos, cada efeito é determinado a existir pelo poder e eficácia daquela causa que lhe precede imediatamente; mas toda a cadeia ou sucessão eterna, tomada em conjunto, não é determinada ou causada por nada - e ainda é evidente que ela requer uma causa ou razão tanto quanto qualquer objeto particular, que começa a existir no tempo. Ademais, é razoável questionar por que esta sucessão particular de causas existiu a partir da eternidade e não de qualquer outra ou nenhuma. Se não houver um Ser necessariamente existente, qualquer suposição que se possa formar é igualmente possível, e tampouco há mais absurdidade em nada ter existido por toda a eternidade do que há nessa sucessão de causas que constitui o universo. O que é, então, que determinou alguma coisa a existir ao invés de coisa alguma, e conferiu ser a alguma possibilidade particular, excluindo-a do resto? Causas externas se supõem nulas. Acaso é uma palavra sem significado. Foi o nada? Mas ele nunca pode produzir coisa alguma. Temos, portanto, que ter recurso a um ser necessariamente existente, que 
carrega em si mesmo a RAZÃo de sua existência e que não se pode supor que inexista sem uma contradição explícita. Consequentemente, há um tal Ser, isto é, há uma Deidade."

4. "Não devo deixar para Filão", disse Cleantes, "(embora eu saiba que levantar objeções é o seu principal deleite) apontar a fraqueza desse raciocínio metafísico. Parece-me tão obviamente mal fundado, e ao mesmo tempo de consequência tão pequena para a causa da piedade e religião verdadeiras, que devo eu mesmo me aventurar a mostrar a sua falácia.

5. "Devo começar observando que há uma absurdidade evidente em pretender demonstrar uma questão de fato ou prová-la por meio de argumentos a priori. Nada é demonstrável, a menos que o contrário implique contradição. Nada que seja concebível de maneira diferente implica contradição. O que quer que concebamos como existente podemos conceber também como inexistente. Não há Ser, portanto, cuja existência seja demonstrável. Proponho este argumento como inteiramente decisivo e estou disposto a confiar-lhe a controvérsia inteira.

6. "Pretende-se que a Deidade é um Ser necessariamente existente, e esta necessidade de sua existência se tenta explicar afirmando que, se conhecêssemos toda a sua essência ou natureza, deveríamos perceber ser-lhe tão impossível não existir quanto duas vezes dois não ser quatro. Mas é evidente que isto nunca pode acontecer enquanto nossas faculdades permanecerem as mesmas de agora. Ainda será possível para nós a qualquer hora conceber a inexistência do que antes concebêramos existir, e tampouco pode a mente estar sempre sob a necessidade de supor que qualquer objeto permaneça sempre em existência do mesmo modo que estamos sob a necessidade de sempre conceber que duas vezes dois é quatro. As palavras existência necessária, portanto, não têm significado algum; ou, o que é a mesma coisa, nenhum que seja consistente. 
7. “Mas, mais ainda: por que não pode o universo material ser o Ser necessariamente existente, de acordo com essa pretensa explicação de necessidade? Não ousamos afirmar que conhecemos todas as qualidades da matéria e, para que possamos determinar isto, ela deve conter algumas qualidades que, fossem conhecidas, fariam sua inexistência parecer uma contradição tão grande quanto duas vezes dois ser cinco. Encontro apenas um argumento empregado para provar que o mundo material não é o Ser necessariamente existente, e este argumento se deriva da contingência tanto da matéria quanto da forma do mundo. 'Qualquer partícula da matéria', diz-se", 'pode-se conceber que seja aniquilada; e qualquer forma pode-se conceber que seja alterada. Uma tal alteração ou aniquilação, portanto, não é impossível.' Mas parece uma grande parcialidade não perceber que o mesmo argumento não se estende igualmente à Deidade, até onde temos uma concepção sua, e que a mente pode ao menos imaginá-la inexistente ou com seus atributos alterados. Têm que ser algumas qualidades desconhecidas, inconcebíveis, que possam fazer sua inexistência parecer impossível ou seus atributos inalteráveis - e não se pode assinalar nenhuma razão por que essas qualidades não pertençam à matéria. Como são completamente desconhecidas e inconcebíveis, nunca podem ser provadas incompatíveis com ela.

8. "Ademais, remontando a uma sucessão eterna de objetos, parece absurdo perguntar por uma causa geral ou primeiro Autor. Como pode alguma coisa que existe desde a eternidade ter uma causa, uma vez que essa relação implica prioridade em tempo e um começo de existência?

9. “Em tal cadeia também, ou sucessão de objetos, cada parte é causada por aquela que a precede e causa aquela que a sucede. Onde então está a dificuldade? Mas o conjunto, dizes, requer

* Dr. Clarke. [Não encontrei a citação original. Em nota ao volume que organiza, Gaskin diz que Hume não cita Clarke, mas parafraseia seu pensamento contido em A Discourse concerning the Being and Attributes of God. (HUME, Dialogues and Natural History of Religion. Oxford University: Oxford, 2008, p. 207.)] 
uma causa. Respondo que unir essas partes em conjunto, assim como unir vários condados distintos em um reino ou vários membros distintos em um corpo, se desempenha tão-só por um ato arbitrário da mente, e não tem influência alguma sobre a natureza das coisas. Se eu te mostrasse as causas particulares de cada indivíduo numa coleção de vinte partículas de matéria, deveria achar nada razoável se me perguntasses depois qual é a causa do conjunto das vinte. Isto é suficientemente explicado ao explicar-se a causa das partes."

10. "Embora os raciocínios que incitaste, Cleantes, possam me dispensar", disse FILÃO, "de levantar novas dificuldades, ainda não posso deixar de insistir noutro tópico. Aritméticos observam que os produtos de 9 compõem sempre ou 9 ou algum produto inferior de 9 , se juntares todos os caracteres dos quais quaisquer desses produtos são compostos. Assim, com 18, 27, 36, que são produtos de 9, formas 9 juntando 1 a 8,2 a 7, 3 a 6 . Assim, 369 também é um produto de 9, e se juntares 3,6 e 9, formas 18 , um produto inferior de 9.* Para o observador superficial, uma regularidade tão maravilhosa pode ser admirada como efeito do acaso ou do desígnio, mas um algebrista habilidoso conclui que é obra da necessidade e demonstra que este deve ser para sempre o resultado da natureza desses números. Não é provável, pergunto eu, que toda a economia do universo seja conduzida por uma necessidade parecida, embora nenhuma álgebra humana possa fornecer uma chave que solva todas as dificuldades? E ao invés de admirarmos a ordem dos seres naturais, não seria capaz de acontecer que, se pudéssemos penetrar a natureza íntima dos corpos, víssemos com clareza por que era absolutamente impossível que eles pudessem admitir qualquer outra disposição? É tão perigoso introduzir esta ideia de necessidade à presente questão! E ela fornece com tanta naturalidade uma inferência diretamente oposta à hipótese religiosa!

* République des Lettres, Août, 1685. 
11. "Mas, largando todas essas abstrações," continuou FILÃo, "e confinando-nos a tópicos mais familiares, aventurar-me-ei a acrescentar uma observação: ${ }^{26} \mathrm{o}$ argumento a priori tem dificilmente se achado muito convincente, exceto à gente duma cabeça metafísica que se acostumou a raciocínios abstratos e, vendo pela matemática que com frequência o entendimento conduz à verdade através de obscuridade e contraria as aparências, transferiu o mesmo hábito de pensar para assuntos onde este não deve ter lugar. Outra gente, mesmo de bom-senso e ao máximo inclinada à religião, sempre sente alguma deficiência em tais argumentos, embora talvez não seja capaz de explicar com distinção onde ela está. Uma prova certa de que homens sempre derivaram e sempre derivarão sua religião de outras fontes que não esta espécie de raciocínio."

26 A passagem que vai desde o do começo do parágrafo 10 até este ponto foi acrescentada entre 1751 e 1763. Toda a passagem foi riscada por Hume e depois a instrução acrescentada, também por Hume, à margem: "Imprime esta passagem." A abertura original do parágrafo 11 era: “'Aventurar-me-ei', disse FILÃo, 'a acrescentar a estes raciocínios de CLEANTES uma observação:"' 


\section{羽arte X}

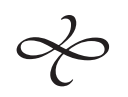

1. "É minha opinião, admito," disse DÊMEAS, "que cada homem sente, de certo modo, a verdade da religião em seu próprio peito; e por consciência de sua fraqueza ${ }^{27}$ e miséria, ao invés de raciocínio, é levado a buscar proteção nesse Ser do qual ele e toda a natureza dependem. Tão ansiosas ou tão tediosas são até mesmo as melhores cenas da vida, que a futurição é ainda o objeto de todas as nossas esperanças e medos. Sem cessar olhamos adiante e tentamos através de preces, adoração e sacrifício, apaziguar aqueles poderes desconhecidos que vemos pela experiência serem tão capazes de nos afligir e oprimir. Criaturas desgraçadas que somos! Qual recurso haveria para nós em meio aos inumeráveis males da vida, não houvesse a religião nos sugerido alguns

27 Aqui, ao vertemos "imbecility", consideramos tratar-se de mais um latinismo de Hume: em latim, imbecilitas é apenas impotência, fraqueza, sem conotação pejorativa do intelecto. 
métodos de expiação e apaziguado aqueles terrores que nos agitam e atormentam incessantemente?"

2. "Estou mesmo persuadido", disse FILÃo, "de que o melhor e, na verdade, o único método para trazer todos a um devido sentimento de religião é por representações justas da miséria e desgraça do homem. E, para esse propósito, o talento para a eloquência e imagens fortes é mais necessário do que aquele para o raciocínio e argumento. Afinal, é necessário provar aquilo que todos sentem dentro de si? É necessário apenas fazer-nos sentir isso, se possível, mais íntima e sensivelmente."

3. "A gente, de fato", replicou DÊMEAs, "está suficientemente convicta desta grande e melancólica verdade. As misérias da vida, a infelicidade do homem, as corrupções gerais da nossa natureza, o gozo insatisfatório dos prazeres, riquezas e honras: estas expressões se tornaram quase proverbiais em todas as línguas. E quem pode duvidar do que todos os homens declaram a partir de suas próprias e imediatas sensação e experiência?"

4. "Neste ponto", disse FILÃo, "os eruditos estão em perfeito acordo com o vulgo; em todas as literaturas, sagrada e profana, se tem insistido no tópico da miséria humana com a eloquência mais comovente que a tristeza e a melancolia poderiam inspirar. Os poetas, que falam pelo sentimento, sem um sistema, abundam em imagens desta natureza. Desde Homero ao Dr. YounG, toda a tribo inspirada sempre teve consciência de que nenhuma outra representação das coisas se adequaria à sensação e observação de cada indivíduo."

5. "Quanto às autoridades", replicou DêMEAS, "não precisas procurá-las. Olha à volta esta biblioteca de Cleantes. Ouso afirmar que, à exceção dos autores de ciências particulares tais como química e botânica, que não têm ocasião de tratar da vida humana, dificilmente haverá um entre esses inúmeros autores de quem o sentimento da miséria humana não tenha extorquido, nalguma passagem, uma queixa e confissão sua. Pelo menos, a 
chance está inteiramente deste lado, e jamais nenhum autor, até onde posso lembrar, foi tão extravagante a ponto de negá-lo."

6. "Aqui me hás de desculpar", disse Filão. "Leibniz o negou, e talvez tenha sido o primeiro* que se aventurou a ter uma opinião tão audaciosa e paradoxal; ou pelo menos o primeiro que o tornou essencial ao seu sistema filosófico."

7. "E por ser o primeiro", replicou DÊMEAs, "não deveria ter se sensibilizado do seu erro? Pois este é um assunto em que filósofos podem se propor a fazer descobertas, especialmente numa era tão tardia? E pode algum homem esperar, com uma simples negação (pois o assunto dificilmente admite raciocínio), derrotar o testemunho unido do gênero humano fundado em sentimento e consciência?

8. "E por que o homem deveria", acrescentou ele, "pretender uma isenção do grupo de todos os outros animais? Crê em mim, FILÃO: A terra inteira é amaldiçoada e poluta. Uma guerra perpétua chameja em meio a todas as criaturas viventes. Necessidades, fome, carência, estimulam o forte e corajoso; medo, ansiedade, terror, agitam o fraco e medroso. A primeira chegada à vida causa sofrimento à criança recém-nascida e à sua desgraçada mãe; fraqueza, impotência e aflição acompanham cada fase da vida - e, ao fim, ela se acaba em agonia e horror."

9. "Observa também", diz FILÃo, "os curiosos artifícios da natureza com o propósito de amargar a vida de todo ser vivo. Os mais fortes oprimem os mais fracos e os mantêm em terror e ansiedade perpétuos. Os mais fracos também, por sua vez, frequentemente oprimem os mais fortes e os vexam e molestam sem descansar. Considera esta raça inumerável dos insetos, que ou são criados no corpo de cada animal ou ficam voando à volta para enfiarem nele seus ferrões. Estes insetos têm outros ainda menores do que si para atormentá-los. E assim a cada lado, à

* Esta opinião foi mantida pelo Dr. King e alguns outros antes de Leibniz, embora por nenhum de fama tão grande quanto a deste filósofo alemão. 
frente e atrás, abaixo e acima, todo animal está rodeado por inimigos que incessantemente buscam sua miséria e destruição."

10. "Apenas o homem", disse DÊMEAS, "parece ser, em parte, uma exceção a essa regra. Pois, pela combinação em sociedade, pode facilmente dominar leões, tigres e ursos cujas força e agilidade maiores naturalmente capacitam a dominá-lo."

11. "Ao contrário, é sobretudo aqui", bradou FILÃo, "que as máximas da natureza uniformes e iguais são mais aparentes. $\mathrm{O}$ homem, é verdade, pode por combinação sobrepujar todos os seus inimigos reais e dominar toda a criação animal - mas ele não levanta contra si próprio inimigos imaginários, os demônios de sua fantasia, que o caçam com terrores supersticiosos e arrasam todo o gozo da vida? Seu prazer, tal como ele o imagina, torna-se aos seus olhos um crime. Sua comida e repouso lhe causam ressentimento e ofensa. Seu sono e seus sonhos fornecem material para um medo ansioso. E mesmo a morte, seu refúgio de todo outro mal, lhe apresenta apenas o pavor de calamidades infindáveis e inumeráveis. Nem o lobo molesta mais o rebanho tímido do que a superstição o peito ansioso de mortais desgraçados.

12. "Ademais, considera, DÊMEAS, esta mesma sociedade, pela qual sobrepujamos aquelas bestas selvagens, nossos inimigos naturais: que novos inimigos ela não levanta contra nós? Que calamidade e miséria ela não ocasiona? O homem é o maior inimigo do homem. Opressão, injustiça, desprezo, insolência, violência, sedição, guerra, calúnia, traição, fraude: através disto se atormentam um ao outro, e dissolveriam logo aquela sociedade que formaram, não fosse o pavor de males ainda maiores que devem acompanhar sua separação."

13. "Mas apesar de essas injúrias externas", disse DÊMEAs, "advindas de animais, homens, - todos os elementos que nos atacam - formarem um terrível catálogo de calamidades, eles nada são em comparação àqueles que surgem em nossas entranhas, 
advindos da condição destemperada de nossa mente e corpo. Quantos não jazem sob o tormento prolongado de doenças? Ouve a enumeração comovente do grande poeta:

A pedra atroz, a cólica tremenda,

$\mathrm{O}$ cancro tragador, a brava fúria,

A magreza das tísicas mirrada,

Da hidropsia os pálidos volumes,

A horrível asma, fulminante gota,

E sobre todas a tartárea peste.

Do pavimento no âmbito retumbam

Sentidos ais, perturbações medonhas;

A DesesPeração, assídua sempre,

De leito em leito furibunda voa;

E triunfante a MORTE o dardo vibra,

Mas pausando, em requinte de fereza,

$\mathrm{O}$ duro golpe aos infelizes que ousam

Com incessante ardor chamar por ela

Como o só bem que lhe termina os males. ${ }^{28}$

14. "As desordens da mente", continuou DêMEAs, "embora mais secretas, talvez não sejam menos lúgubres e vexatórias. Remorso, vergonha, angústia, raiva, desapontamento, ansiedade, medo, depressão, desespero - quem já passou pela vida sem incursões cruéis desses atormentadores? Quantos quase nunca tiveram quaisquer sensações melhores? Labor e pobreza, tão detestados por todos, são o quinhão certo da vastíssima maioria dos homens - e aquelas poucas pessoas privilegiadas que gozam de facilidades e opulência nunca alcançam contentamento ou felicidade verdadeira. Todos os bens da vida reunidos não fariam um homem verdadeiramente feliz, mas todas os males reunidos de fato fariam um desgraçado. E quase que qualquer destes (e quem pode ser livre de todos?) - mais ainda, frequentemente a

28 Kemp Smith informa que esta é uma citação de Paradise Lost, XI, de Milton. Usei a mesma versão. 
ausência de um único bem (e quem possui todos?) - basta para tornar a vida inelegível.

15. "Acontecesse de, súbito, cair neste mundo um estranho, eu lhe mostraria como um espécime de seus males um hospital cheio de doentes, uma prisão cheia de malfeitores e devedores, um campo de batalha encoberto de carcaças, uma frota naufragando no oceano, uma nação agonizando sob tirania, fome ou pestilência. Para mostrar-lhe o lado alegre da vida e dar-lhe uma noção dos seus prazeres, para onde eu deveria conduzi-lo? Para um baile, uma ópera, à corte? Ele poderia pensar com justeza que eu estava lhe mostrando uma variedade de aflição e tristeza."

16. "Não há como evitar exemplos tão arrebatadores", disse FILÃo, "senão por meio de apologias, que agravam ainda mais a acusação. Por que todos os homens, pergunto, em todas as eras, se queixaram incessantemente da miséria de suas vidas...? 'Eles não têm nenhuma razão exata', diz alguém ${ }^{29}$, 'estas queixas procedem apenas de suas disposições descontentes, reclamonas, ansiosas...' E é possível, replico, ter um fundamento mais certo para a miséria do que tal temperamento desgraçado?

17. "'Mas, se eles forem realmente tão infelizes quanto pretendem', diz meu antagonista, 'por que permanecem na vida...?

Insatisfeitos com a vida, tementes à morte ${ }^{\prime 30}$

29 Note-se que Hume duplica aqui sua estratégia de colocar posições censuráveis em diálogo: é um interlocutor hipotético combatido por uma personagem que deve ceder nestes diálogos. $\mathrm{O}$ duplo escrúpulo se explica quando vemos que ele esboçará tratar do suicídio. Cf. seu apologético ensaio "Of Suicide".

30 Não tendo sido encontrada, esta citação gera especulações de tradutores e editores. Parece ser uma citação às avessas de Lucrécio, que disse dos que viveram a peste de Atenas: "cobiçosos da vida, tementes à morte" (RN, VI,1240). Significativamente, tratava-se de um ambiente desgraçado onde as pessoas cobiçavam a vida. Por o De rerum natura ser um livro bem conhecido à época, e ser clássica a sua descrição da peste, era de esperar que o leitor erudito reconhecesse uma passagem, mesmo adulterada. 
Esta é a cadeia secreta, digo eu, que nos contém. Estamos aterrorizados, não tentados pela continuidade da nossa existência.

18. “'Isto é apenas uma sutileza falsa', poderá ele insistir, 'que satisfaz uns poucos espíritos e espalha essas queixas por toda a raça humana...' E o que é essa sutileza, pergunto, que culpas? É alguma coisa que não uma sensibilidade maior de todos os prazeres e dores da vida? E se um homem de temperamento cortês, refinado, por ser tão mais vivo que o resto do mundo, for apenas tanto mais infeliz, que juízo temos que formar em geral da vida humana?

19. 'Permaneçam os homens em repouso', diz nosso adversário, 'e ficarão tranquilos. São artífices voluntários de sua própria miséria...' Não!, replico, uma languidez ansiosa segue seu descanso: desapontamento, vexação, problemas, sua atividade e ambição."

20. "Posso observar em algumas outras pessoas algo parecido com o que mencionas" replicou Cleantes, "Mas confesso que não sinto nada disso em minhas entranhas e espero que não seja tão comum quanto representas."

21. "Tu próprio não sentes a miséria em tuas entranhas?!", bradou DÊMEAs, "Eu te parabenizo por singularidade tão feliz. Outros, aparentemente os mais prósperos, não se envergonharam de manifestar suas queixas nos estilos mais melancólicos. Ouçamos o grande, o afortunado Imperador Carlos V quando, cansado da grandeza humana, renunciou a todos os seus domínios extensos em prol do seu filho. Em sua última arenga, feita nessa ocasião memorável, admitiu publicamente que 'as maiores prosperidades das quais jamais gozara se misturaram com tantas adversidades, que poderia dizer em verdade nunca ter gozado de qualquer satisfação ou contentamento'. Mas a vida aposentada na qual ele procurou abrigo lhe forneceu alguma felicidade maior? Se pudermos confiar no relato do seu filho, seu arrependimento começou no próprio dia de sua renúncia. 
22. "A fortuna de Cícero, de origem modesta se elevou aos maiores esplendor e fama; ainda assim, que queixas comoventes dos males da vida não contêm suas Cartas aos amigos, bem como seus discursos filosóficos? E, como que adaptável a sua própria experiência, ele introduz CATÃO - o grande, o afortunado CATÃO - protestando contra sua idade avançada dizendo que, tivesse ele uma nova vida à sua oferta, rejeitaria a presente.

23. "Pergunta-te a ti próprio, pergunta a qualquer um que conheças, se acaso viveria de novo os últimos dez ou vinte anos de sua vida. Não! Mas os próximos vinte, dirá, serão melhores:

\section{E dos resíduos da vida, espera receber}

O que o primeiro, vigorosamente, rápido não pôde dar. ${ }^{31}$

Assim, ao cabo percebem (tal é a grandeza da miséria humana: reconcilia até contradições) que reclamam, a um só tempo, da brevidade da vida e de sua vaidade e tristeza."

24. "E será possível, Cleantes", disse Filão, "que depois de todas essas reflexões e infinitas mais que se podem sugerir, ainda perseveres em teu antropomorfismo e assiras os atributos morais da Deidade, que sua justiça, benevolência, piedade e retidão sejam da mesma natureza que essas virtudes em criaturas humanas? Admitimos que seu poder é infinito: o que quer que ela queira é executado. Mas nem os homens e nem os animais são felizes - portanto, ela não quer a felicidade deles. Admitimos que sua sabedoria é infinita; ela nunca se engana ao escolher os meios para quaisquer fins. Mas o curso da natureza não tende à felicidade humana ou animal - portanto, não está estabelecido com este propósito. Através de todo o âmbito do conhecimento humano, não há inferências mais certas e infalíveis do que estas.

31 Segundo Kemp Smith, esta é uma citação de Dryden, Aurengzebe, Ato IV, cena I, e Hume escreveu "espera" ao invés de "pensa". 
A que respeito, então, sua benevolência e piedade se assemelham à do homem?

25. "As velhas questões de EPICURO continuam ainda sem resposta. É desejosa de prevenir o mal, mas incapaz? Então é impotente. É capaz, mas não é desejosa? Então é malevolente. É capaz e desejosa ao mesmo tempo? Donde vem então o mal?

26. "Atribuis, Cleantes (e creio que com justeza), um propósito e intenção à natureza. Mas qual é, rogo que respondas, o objetivo desse curioso artifício e maquinaria que ela dispôs em todos os animais? Apenas a preservação dos indivíduos e a preservação da espécie. Parece bastar ao propósito dela se tal posto for precariamente preservado no universo, sem qualquer preocupação com a felicidade dos membros que o compõem. Nenhum recurso para este propósito, nenhuma maquinaria a fim de meramente dar prazer ou tranquilidade, nenhuma fonte de pura alegria e contentamento, nenhum prazer sem qualquer carência ou necessidade o acompanhando - no mínimo, os poucos fenômenos desta natureza são sobrepujados por fenômenos opostos de importância ainda maior.

27. "Nosso senso de música, harmonia, e, de fato, da beleza de todos os tipos, dá satisfação sem ser absolutamente necessário à preservação e propagação da espécie. Mas que dores excruciantes, por outro lado, surgem de gotas, pedras renais, enxaquecas, dores de dente, reumatismos - onde a injúria à maquinaria animal é ou pequena ou incurável? Alegria, gargalhada, jogo, brincadeira, parecem satisfações gratuitas que não têm maior tendência; mau humor, melancolia, descontentamento, superstição, são dores da mesma natureza. ${ }^{32}$ Como então se manifesta a benevolência divina, no vosso sentido, antropomorfistas? Ninguém senão nós místicos, como ficastes contentes em chamar-nos, pode explicar

32 Entenda-se: são da mesma natureza porque tanto umas quanto outras são desnecessárias à manutenção da espécie. 
esta estranha mistura de fenômenos, derivando-a de atributos infinitamente perfeitos porém incompreensíveis."

28. "Enfim", disse CleANTES sorrindo, "traíste tuas intenções, FILÃO? Tua longa concordância com DÊMEAS de fato surpreendeu-me um pouco, mas vejo que estavas todo o tempo erigindo contra mim uma bateria disfarçada. E tenho de confessar que agora caíste num assunto digno de teu nobre espírito de oposição e controvérsia. Se podes conseguir o presente ponto e provar que a humanidade é infeliz ou corrupta, aí está duma vez por todas o fim de toda religião. Pois para que propor estabelecer os atributos naturais da Deidade, enquanto os morais ainda são duvidosos e incertos?"

29. "Ofendes-te muito fácil", replicou DÊMEAs, "com as opiniões mais inocentes e mais geralmente aceitas mesmo entre os próprios religiosos e devotos - e nada pode ser mais surpreendente do que ver um tópico como este, que concerne à desgraça e miséria do homem, acusado de nada menos que ateísmo e profanidade. Todos os pios teólogos e padres que dispensaram sua retórica a um assunto tão fértil não deram, digo eu, uma solução fácil que pode acompanhá-lo? Este mundo é apenas um ponto em comparação ao universo; esta vida, apenas um momento em comparação à eternidade. Os presentes fenômenos maus, portanto, são retificados noutras regiões e nalgum período de existência futuro. E os olhos do homem, sendo então abertos para vistas mais largas das coisas, veem toda a conexão de leis gerais e remonta, com adoração, à benevolência e retidão da Deidade através de todos os labirintos e complicações de sua providência."

30. "Não!”, replicou CleANTES, "Não! Essas suposições arbitrárias nunca podem ser admitidas, são contrárias a questão de fato visível e incontrovertida. Por onde se pode conhecer qualquer causa senão por seus efeitos conhecidos? Por onde pode se pode provar qualquer hipótese senão pelos fenômenos aparentes? Estabelecer uma hipótese sobre outra é construir inteiramente so- 
bre ar; e o mais extremo que podemos conseguir através destas conjecturas e ficções é descobrir a mera possibilidade de nossa opinião, mas nunca podemos, sobre tais termos, estabelecer sua realidade.

31. “O único método de sustentar a benevolência divina (e o único que abraço de boa vontade) é negar absolutamente a miséria e desgraça do homem. Tuas representações são exageradas; tuas visões melancólicas, majoritariamente fictícias: tuas inferências, contrárias a fato e experiência. A saúde é mais comum que a doença, o prazer que a dor, a felicidade que a miséria. E para cada vexação que encontremos, conseguimos, computando, uma centena de gozos."

32. "Admitindo tua posição," replicou FILÃo, "que ainda é extremamente duvidosa, tens ao mesmo tempo que admitir que se a dor for menos frequente do que o prazer, ela é infinitamente mais violenta e durável. Uma hora cheia dela é frequentemente capaz de valer mais do que um dia, uma semana, um mês de nossos gozos insípidos comuns - e quantos dias, semanas e meses parecem vários, durantes os tormentos mais agudos? O prazer dificilmente é capaz de numa única situação alcançar êxtase e embevecimento, e em nenhuma situação pode continuar por um tempo no seu mais elevado pico. Os espíritos evaporam, os nervos relaxam, a estrutura fica desordenada e o gozo rapidamente se degenera em fadiga e desconforto. Mas a dor frequentemente, bom Deus!, quão frequentemente!, evolui para tortura e agonia, e quanto mais perdura, torna-se ainda mais genuína tortura e agonia. A paciência se exaure, a coragem se enlanguesce, a melancolia nos toma, e nada termina nossa miséria senão a remoção de sua causa ou um outro evento que é a única cura de todos os males, mas que, por nossa tolice natural, olhamos com terror e consternação ainda maiores.

33. "Mas para não insistir nesses tópicos", continuou FILÃO, "embora sejam os mais óbvios, certos e importantes, tenho que 
usar de liberdade para repreender-te, ClEANTES, por teres posto esta controvérsia sobre a questão mais perigosa, e estares inadvertidamente introduzindo um ceticismo total nos artigos mais essenciais de teologia natural e revelada. O quê!, nenhum método de fixar um fundamento justo para a religião, a menos que admitamos a felicidade da vida humana e digamos que uma existência contínua mesmo neste mundo, com todas as nossas presentes dores, debilidades, vexações e tolices, é elegível e desejável! Mas isto é contrário ao sentimento e experiência de todos; é contrário a uma autoridade estabelecida de modo que nada possa subvertê-la - e tampouco é possível computares, estimares e comparares todas as dores e todos os prazeres nas vidas de todos os homens e todos os animais. Assim, por colocares todo o sistema da religião dependente dum ponto que, por conta de sua própria natureza, tem para sempre que ser incerto, confessas tacitamente que este sistema é igualmente incerto.

34. "Mas, concedendo-te aquilo em que jamais se acreditará; que, no mínimo, jamais poderás provar - que a felicidade animal ou ao menos a humana durante a vida excede a miséria -, ainda assim não fizeste nada. Afinal, isto não é de jeito nenhum o que esperamos de poder infinito, sabedoria infinita e bondade infinita. Por que há alguma miséria no mundo? Certamente não por acaso. Por alguma causa, então. É pela intenção da Deidade? Mas ela é perfeitamente benevolente. É contrária à sua intenção? Mas ela é todo-poderosa. Nada pode abalar a solidez deste raciocínio tão curto, tão claro, tão decisivo; exceto se afirmarmos que estes assuntos excedem toda a capacidade humana e que nossas medidas comuns de verdade e falsidade não lhes são aplicáveis. E este é um tópico no qual tenho insistido durante todo o tempo, mas que rejeitaste, desde o começo, com desdém e indignação.

35. "Mas ainda assim contentar-me-ei em retirar-me deste entrincheiramento, pois nego que me possas forçar a permanecer aí. Concederei que dor ou miséria no homem é compatível com 
o poder e bondade infinitos da Deidade mesmo no teu sentido desses atributos. Em que avançaste com todas estas concessões? Uma compatibilidade meramente possível não é suficiente. Tens que provar estes atributos puros, sem mistura e incontroláveis a partir dos presentes fenômenos misturados e confusos, e a partir deles apenas. Que empreendimento esperançoso! Fossem os fenômenos alguma vez tão puros e sem mistura, permanecendo finitos seriam insuficientes para este propósito. Tanto mais quando eles são também tão dissonantes e discordantes!

36. "Aqui, Cleantes, me vejo confortável em meu argumento. Aqui, eu triunfo. Antes, quando discutíamos os atributos naturais de inteligência e desígnio, eu precisava de toda a minha sutileza cética e metafísica para eludir a tua apreensão. Em muitos aspectos do universo e de suas partes, particularmente destas, a beleza e adequação das causas nos arrebata com força tão irresistível que todas as objeções parecem (o que creio que elas realmente sejam) meras cavilações e sofismas; e tampouco podemos imaginar então como foi possível termos lhes dado algum peso. Mas não há aspecto da vida humana ou da condição da humanidade a partir do qual, sem a maior violência, possamos inferir os atributos morais ou conhecer tal benevolência infinita, conjugada a poder infinito e sabedoria infinita, que temos de descobrir apenas pelos olhos da fé. É tua vez agora de puxar o trabalhoso remo e sustentar tuas sutilezas filosóficas contra os ditames da razão e experiência evidentes." 


\section{\#arte XI}

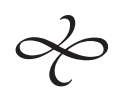

1. "Não hesito em admitir", disse Cleantes, "que fui capaz de suspeitar da repetição frequente da palavra 'infinito' que encontramos em todos os escritores teológicos, cheirando mais a panegírico do que a filosofia, e que quaisquer propósitos de raciocínio, e mesmo de religião, seriam melhor servidos se nos contentássemos com expressões mais acuradas e mais moderadas. Os termos 'admirável', 'excelente', 'superlativamente grande', 'sábio' e 'sagrado', preenchem suficientemente as imaginações dos homens; e qualquer coisa acima disso, além de levar a absurdidades, não tem influência sobre nossas afecções ou sentimentos. Assim, no presente assunto, se abandonarmos toda analogia humana, como parece ser tua intenção, DÊMEAS, receio que abandonemos toda religião e não retenhamos concepção alguma do grande objeto de nossa adoração. Se preservarmos a analogia humana, teremos para sempre que achar impossível reconciliar qualquer mescla de 
mal no universo com atributos divinos; poderemos menos ainda provar a última pela primeira. Mas supondo que o Autor da natureza seja finitamente perfeito mas exceda em muito a humanidade, pode-se dar então uma explicação satisfatória para o mal natural e moral, e explicar-se e ajustar-se todo fenômeno adverso. Pode-se então escolher um mal menor para evitar outro maior, resignar-se com inconveniências para alcançar um fim desejável - e, numa palavra, a benevolência, regulada pela sabedoria e limitada pela necessidade, pode produzir justo um mundo tal como o presente. Tu, FILÃo, que és tão disposto a levantar aspectos e reflexões e analogias: eu ficaria contente em ouvir detalhadamente, sem interrupção, tua opinião a respeito desta teoria nova; e, se ela merecer nossa atenção, podemos depois, com mais vagar, reduzi-la a uma forma."

2. "De minhas opiniões", replicou FILÃo, "não é digno de que se faça mistério; e portanto, sem qualquer cerimônia, hei de proferir o que me ocorre a respeito do presente assunto. Tem-se, penso eu, que admitir que, caso uma inteligência limitadíssima, à qual supomos que o universo seja maximamente estranho, estivesse bem segura de que este é a produção dum Ser boníssimo, sapientíssimo e poderosíssimo porém finito, ela formaria de antemão por suas conjecturas uma noção do mundo diferente daquilo que por experiência o vemos ser. E jamais imaginaria, meramente a partir daqueles atributos da causa do qual fora informada, que o efeito pudesse ser tão cheio de vício, miséria e desordem como aparece nesta vida. Supondo agora que esta pessoa fosse trazida ao mundo ainda segura de que este é a obra de tal Ser sublime e benevolente, ela poderá, talvez, se surpreender com o desapontamento, mas nunca renunciaria à sua crença anterior se esta for fundada nalgum argumento bem sólido, já que uma inteligência tão limitada deve estar cônscia de sua cegueira e ignorância e tem de admitir que pode haver para tais problemas muitas soluções que sempre escaparão à sua compreensão. 
Mas supondo - o que é o real caso do homem -, que esta criatura não esteja anteriormente convencida duma inteligência suprema benevolente e poderosa, mas fique livre para colher tal crença pelas aparências das coisas: altera-se completamente o caso, e ela não achará qualquer razão para tal conclusão. Poderá estar plenamente convencida dos limites estreitos do seu entendimento, mas isto não lhe ajudará a formar uma inferência concernente à bondade dos poderes superiores, pois tem que formá-la a partir daquilo que conhece, não daquilo que ignora. Quanto mais exageras sua fraqueza e ignorância, mais desconfiada torna-la, e lhe dás uma suspeita maior de que tais assuntos estão além do alcance de suas faculdades. Estás obrigado, portanto, a raciocinar com essa criatura a partir meramente dos fenômenos conhecidos e a largar toda suposição ou conjectura arbitrárias.

3. "Mostrasse eu a ti uma casa ou palácio onde não houvesse nenhum aposento conveniente ou agradável, onde as janelas, portas, lareiras, passagens, escadas e toda a economia da construção fossem a fonte de barulho, confusão, fadiga, escuridão, e os extremos de calor e frio, certamente culparias a invenção sem quaisquer exames mais extensos. Em vão o arquiteto exporia sua sutileza e te provaria que se esta porta ou aquela janela fossem alteradas males maiores se seguiriam. $\mathrm{O}$ que ele diz pode ser estritamente verdadeiro: a alteração dum particular, enquanto as outras partes da construção permanecem, pode apenas aumentar as inconveniências. Mas ainda afirmarias no geral que, houvesse o arquiteto tido habilidade e boas intenções, deveria ter formado certo plano do todo e deveria ter ajustado as partes em tal maneira que teria remediado todas ou quase todas essas inconveniências. Sua ignorância, ou mesmo tua própria ignorância desse plano, nunca te convencerão da impossibilidade dele. Se vires muitas inconveniências e deformidades na construção, sempre, sem entrar em detalhes, condenarás o arquiteto. 
4. "Repito a questão brevemente: $\mathrm{O}$ mundo, considerado em geral e como nos aparece nesta vida, é diferente do que um homem ou tal ser limitado iriam, de antemão, esperar duma Deidade poderosíssima, sapientíssima e benevolentíssima? Há de ser um preconceito estranho asserir o contrário. E disto concluo que, por consistente que o mundo possa ser, admitir certas suposições e conjecturas com a ideia de tal Deidade nunca pode nos fornecer uma inferência concernente à sua existência. A consistência não é negada de modo algum; apenas a inferência. Conjecturas, especialmente onde a infinitude é excluída dos atributos divinos, talvez possam ser suficientes para provar certa consistência, mas nunca poderão ser fundamentos para qualquer inferência.

5. "Parece haver quatro circunstâncias das quais dependem todos ou a maior parte dos males que molestam as criaturas sensíveis, e é possível que nem todas essas circunstâncias sejam necessárias e inevitáveis. Sabemos tão pouco além da vida comum - ou mesmo da própria vida comum - que, a respeito da economia inteira dum universo, não há conjectura que, por mais que extravagante, não possa ser exata; nem que, por mais que plausível, não possa ser errônea. Tudo o que cabe ao entendimento humano, nessa ignorância e obscuridade profundas, é ser cético ou ao menos cuidadoso e não admitir hipóteses, muito menos uma que não se sustente por aparência alguma de probabilidade. Agora, assiro ser este o caso a respeito de todas as causas do mal e das circunstâncias das quais ele depende. Nenhum deles parece à razão humana, no mínimo grau, necessário ou inevitável; e tampouco podemos supor que o sejam sem a mais extrema licença da imaginação.

6. "A primeira circunstância que introduz o mal é o engendro ou economia da criação animal, pelo qual dores, bem como prazeres, são empregados para exortar todas as criaturas à ação e torná-las vigilantes no grande trabalho da autopreservação. Ora, o prazer sozinho, em seus vários graus, parece ao entendimento 
humano suficiente para este propósito. Todos os animais poderiam estar constantemente num estado de gozo mas, quando incitados por quaisquer necessidades da natureza como sede, fome, fadiga, ao invés de da dor sentiriam uma diminuição de prazer pela qual seriam incitados a buscar o objeto que é necessário à sua subsistência. Os homens caçam o prazer tão avidamente quanto evitam a dor; pelo menos, devem ter sido assim constituídos. Parece, portanto, plenamente possível levar adiante os negócios da vida sem qualquer dor. Por que, então, cada animal sempre foi feito suscetível a tal sensação? Se os animais podem ficar livres dela numa hora, são capazes de gozar duma perpétua isenção dela; e é preciso certo engendro particular de seus órgãos para produzir essa sensação, bem como para dotá-los com visão, audição ou quaisquer dos sentidos. Devemos conjecturar que tal engendro foi necessário, sem qualquer aparência ou razão? E devemos construir sobre esta conjectura como sobre a verdade mais certa?

7. "Mas uma capacidade de dor não iria sozinha produzir dor não houvesse a segunda circunstância, a saber, a condução do mundo por leis gerais - e isto não parece de modo algum necessário para um Ser perfeitíssimo. É verdade: se todas as coisas fossem conduzidas por volições particulares, o curso da natureza seria perpetuamente quebrado e nenhum homem poderia empregar sua razão na conduta da vida. Mas não podem outras volições particulares remediar essa inconveniência? Em poucas palavras: não poderia a Deidade exterminar todo mal onde quer que ele se encontrasse e produzir todo bem sem qualquer preparação ou progresso longo de causas e efeitos?

8. "Ademais, temos que considerar que, de acordo com a presente economia do mundo, o curso da natureza, embora se suponha exatamente regular, ainda assim não no-lo parece: muitos eventos são incertos e muitos desapontam nossas expectativas. Saúde e doença, calmaria e tempestade, junto com um núme- 
ro infinito doutros acidentes cujas causas são desconhecidas e variáveis, têm uma grande influência tanto sobre as fortunas de pessoas particulares quanto sobre a prosperidade de sociedades públicas - e de fato, toda vida humana de certo modo depende desses acidentes. Um Ser, portanto, que conhece os motores secretos do universo, pode facilmente, por volições particulares, voltar todos esses acidentes para o bem da humanidade e tornar toda ela feliz em qualquer operação. Uma frota cujos propósitos fossem salutares à sociedade poderia sempre encontrar bons ventos, bons príncipes sempre gozarem de boa saúde e vida longa, pessoas nascidas para o poder serem sempre constituídas de bom temperamento e disposições virtuosas... Uns poucos eventos como estes, conduzidos regular e sabiamente, mudariam a face do mundo e ainda assim não pareceriam mais perturbar o curso da natureza ou a conduta humana do que a presente economia das coisas, onde as causas são secretas, variáveis e compostas. Alguns pequenos toques dados ao cérebro de CaLígula em sua infância poderiam tê-lo convertido num TRAJANO; uma onda um pouco maior do que as outras, enterrando CÉSAR e sua fortuna no fundo do oceano, poderia ter devolvido a liberdade a uma parte considerável da humanidade. Pode haver, pelo que sabemos, boas razões pelas quais a providência não se interpôs dessa maneira, mas elas nos são desconhecidas - e embora a mera suposição de que tais razões existem possa ser suficiente para salvar a conclusão concernente aos atributos divinos, ainda assim, decerto não pode nunca ser suficiente para estabelecer tal conclusão.

9. "Se tudo no universo for conduzido por leis gerais e os animais forem feitos suscetíveis à dor, dificilmente parece possível que apenas alguns males tenham que surgir nos vários choques da matéria e nas várias concorrências e oposição às leis gerais mas este mal seria bem raro, não fosse pela terceira circunstância que me propus mencionar, a saber, a grande frugalidade com a 
qual todos os poderes e faculdades são distribuídos a todo ser particular. Tão bem ajustados são os órgãos e capacidades de todo animal, e tão bem adequados à sua preservação, que até onde a história alcança parece não haver uma única espécie que já tenha sido extinta no universo. ${ }^{33}$ Todo animal tem os dons de que precisa, mas estes são concedidos com uma economia tão escrupulosa que qualquer diminuição considerável tem que destruir completamente a criatura. Onde quer que um poder seja aumentado, há um abatimento proporcional nos outros. Animais que excelem em velocidade são comumente defectivos em força. Aqueles que possuem ambas ou são imperfeitos nalguns dos seus sentidos ou são oprimidos pelas necessidades mais ávidas. A espécie humana, cuja excelência principal é a razão ou sagacidade, é de todas as outras a mais necessitosa e a mais deficiente em vantagens corpóreas: sem roupas, sem armas, sem comida, sem alojamento, sem qualquer conveniência da vida, exceto o que ela deve à sua própria habilidade e indústria. Em poucas palavras: a natureza parece ter feito um cálculo exato das necessidades de suas criaturas; e, como um mestre rígido, lhes forneceu uns poucos poderes ou dons a mais do que os que são estritamente suficientes para suprir aquelas necessidades. Um pai indulgente teria concedido um estoque largo a fim de guardar contra acidentes e assegurar a felicidade e bem-estar da criatura até na mais desafortunada concorrência das circunstâncias. Todo o curso da vida não seria tão arrodeado por precipícios que o mínimo desvio do caminho, por erro ou necessidade, tenha que nos envolver em miséria e ruína. Alguma reserva, algum fundo teria

33 Aqui haveria esta nota, que foi riscada: "CÉSAR, falando dos bosques na Germânia, menciona alguns animais como subsistentes lá que estão agora absolutamente extintos. De Bello Gall: lib. 6. Estes e mais alguns poucos exemplos podem ser exceções à proposição proferida aqui. Estrabão (lib. 44) cita através de PolíBIo a descrição dum animal em torno de Tirol que não mais se encontra. Se PolíbIo não estava enganado, o que é possível, o animal deveria à época ser bem raro, já que ESTRABÃo cita apenas uma autoridade e fala com dúvida." 
sido provido para assegurar a felicidade, e os poderes e necessidades não teriam sido ajustados com uma economia tão rígida. O Autor da natureza é inconcebivelmente poderoso; sua força se supõe grande, se não completamente inexaurível - e tampouco há qualquer razão, até onde possamos julgar, para fazê-lo observar essa frugalidade estrita em sua conduta com as criaturas. ${ }^{34}$ Teria sido melhor, fosse este poder extremamente limitado, ter criado menos animais e tê-los dotado com mais faculdades para a sua felicidade e preservação. Um construtor nunca é tido por prudente se empreende um plano além do que seu estoque o capacitará terminar.

10. "Para de curar a maioria dos males da vida humana, não peço que o homem tenha as asas da águia, a velocidade do cervo, a força do boi, as armas do leão, as escamas do crocodilo ou rinoceronte; e muito menos demando a sagacidade dum anjo ou querubim. Fico contente em tomar um aumento num único poder de faculdade de sua alma. Que ele seja dotado com uma propensão maior à indústria e ao labor, um motor e uma atividade da mente mais vigorosos, um pendor mais constante para a ocupação e a aplicação. Que a espécie inteira possua naturalmente uma diligência igual àquela que muitos indivíduos são capazes de alcançar por hábito e reflexão, e as consequências mais benéficas, sem qualquer redução do mal, é o resultado imediato e necessário desse dom. Quase todos os males morais, bem como os naturais, surgem da preguiça: fosse nossa espécie, por sua constituição original, isenta desse vício ou fragilidade, o cultivo perfeito da terra, o melhoramento das artes e manufaturas, a execução exata de todo ofício e dever, se seguiriam imediatamente - e duma vez os homens poderiam alcançar plenamente aquele estado de sociedade que se obtém tão imperfeitamente pelo governo melhor regulado. Mas como a industriosidade é

\footnotetext{
34 A passagem que começa neste ponto e inclui o próximo parágrafo foi acrescentada entre 1751 e 1763 , tendo sido depois ainda riscada e reescrita.
} 
um poder, e o mais valioso de todos, a natureza parece determinada, conforme às suas máximas usuais, a concedê-la com uma mão bem poupadora aos homens; e ao invés de puni-los por sua deficiência disto, recompensa-os por seus êxitos. Ela engendrou sua constituição de modo que nada, senão a necessidade mais violenta, possa obrigá-los a trabalhar; e emprega todos os outros desejos do homem de modo a superarem, ao menos em parte, o desejo de diligência, e dotá-los com alguma quota da faculdade que ela achou naturalmente adequada para afligi-los. Aqui pode-se admitir que nossos pedidos são bem humildes e, portanto, mais razoáveis. Se pedíssemos os dons de penetração e juízo superiores, gosto mais delicado de beleza, sensibilidade melhor a benevolência e amizade, poderíamos ouvir que pretendemos impiamente quebrar a ordem da natureza, que queremos ascender a um nível mais alto de existência que representa o que requeremos mas, não sendo adequado ao nosso estado e condição, nos seria apenas pernicioso. Mas é difícil, ouso repeti-lo, é difícil que, tendo sido colocados num mundo tão cheios de desejos e necessidades, onde quase todo ser e elemento ou é nosso inimigo ou nos recusa sua assistência... tenhamos ainda nosso próprio temperamento para lutarmos contra e nos privemos daquela única faculdade que pode se esgrimir contra esses males multiplicados.

11. "A quarta circunstância donde surge a miséria e mal do universo é o acabamento desacurado de todos os motores e princípios da máquina tão grande da natureza. Tem de se reconhecer que há umas poucas partes do universo que não parecem servir a nenhum propósito e cuja remoção não produziria um defeito visível e desordem no todo. As partes dependem umas das outras, e uma não pode ser tocada sem afetar o resto num grau maior ou menor. Mas ao mesmo tempo deve-se observar que nenhuma dessas partes ou princípios, por mais que úteis, é tão acuradamente ajustada de modo a se manterem precisamente entre esses limites em que sua utilidade consiste; ao contrário, são todas 
elas capazes, em toda ocasião, de correr dum extremo a outro. Imaginar-se-ia que esta grande produção não recebeu o mínimo toque do criador, de tão pouco acabada que é toda parte e de tão grosseiros que são os golpes com que é executada. Assim, os ventos são necessários para fornecer vapores ao longo da superfície do globo e assistir os homens na navegação - mas com quanta frequência, chegando a tempestades e furacões, não se tornam perniciosos? As chuvas são necessárias para nutrir todas as plantas e animais da terra - mas com quanta frequência elas não são defectivas? Com quanta não são excessivas? O calor é necessário a toda a vida e vegetação, mas não é sempre encontrado na proporção devida. Da mistura e secreção dos humores e sucos do corpo depende a saúde e prosperidade do animal, mas as partes não desempenham regularmente sua função adequada. $\mathrm{O}$ que é mais útil do que todas as paixões da mente, ambição, vaidade, amor, raiva? Mas com quanta frequência não rompem seus limites e causam as maiores convulsões na sociedade? Nada há de tão vantajoso no universo que contudo não se torne frequentemente pernicioso por seu excesso ou defectividade; e a natureza não resguardou com o cuidado necessário contra a desordem e confusão. A irregularidade nunca é, talvez, tão grande de modo a destruir alguma espécie, mas é frequentemente suficiente para envolver os indivíduos em ruína e miséria.

12. “Da concorrência, então, destas quatro circunstâncias, depende todo ou a maior parte do mal natural. Fossem todas as criaturas viventes incapazes de sentir dor, ou fosse o mundo administrado por volições particulares, o mal nunca poderia ter encontrado acesso ao universo - e fossem os animais dotados dum estoque maior de poderes e faculdades além do que a estrita necessidade requer, ou fossem os vários motores e princípios do universo tão acuradamente tramados de modo a preservarem o temperamento e o meio justos, deveria ter havido pouquíssimo mal em comparação ao presente. Então o que pronunciare- 
mos sobre esta ocasião? Diremos que estas circunstâncias não são necessárias e que poderiam facilmente ter sido alteradas no engendro do universo? Esta decisão parece presunçosa demais para criaturas tão cegas e ignorantes. Sejamos mais modestos em nossas conclusões. Admitamos que, se a bondade da Deidade (quero dizer, uma bondade como a humana) pode ser estabelecida a priori sobre quaisquer razões toleráveis, esses fenômenos, por mais que desfavoráveis, não seriam suficientes para subverter aquele princípio, mas podem facilmente, dalguma maneira desconhecida, ser reconciliáveis com eles. Mas ainda assiramos que, como essa bondade não é estabelecida anteriormente e tem que ser inferida a partir dos fenômenos, então não pode haver fundamento para tal inferência enquanto ainda há tantos males no universo e estes poderiam tão facilmente ter sido remediados, até onde se pode permitir ao entendimento humano julgar tal assunto. Sou cético o suficiente para admitir que as más aparências, malgrado todos os meus raciocínios, possam ser compatíveis com tais atributos como supões - mas elas certamente nunca provarão esses atributos. Tal conclusão nunca pode resultar de ceticismo, mas tem que surgir dos fenômenos e de nossa confiança nos raciocínios que deduzimos desses fenômenos.

13. ${ }^{35}$ "Olha à volta este universo. Que imensa profusão de seres, animados e organizados, sensíveis e ativos! Admiras esta prodigiosa variedade e fecundidade. Mas inspeciona um pouco mais estreitamente essas existências viventes, os únicos seres dignos de notarmos. Como são hostis e destrutivos uns para com os outros! Como são insuficientes todos eles à sua própria felicidade! Como são detestáveis ou odiosos ao espectador! O todo nada apresenta senão a ideia duma natureza cega, emprenhada por um grande princípio vivificante e despejando do seu colo, sem discernimento ou cuidado parental, suas crianças aleijadas e abortivas.

35 Este parágrafo foi acrescentado entre 1751 e 1763. 
14. "Aqui o sistema MANIQUeÍsta ocorre como uma hipótese adequada para resolver a dificuldade: sem dúvida, nalguns respeitos é especiosíssimo, e tem mais probabilidade do que a hipótese comum por dar uma explicação plausível da estranha mistura de bem e mal que aparece na vida. Mas se considerarmos, por outro lado, a perfeita uniformidade e acordo entre as partes do universo, não devemos descobrir nele quaisquer marcas do combate entre um Ser malevolente e um benevolente. Há, de fato, uma oposição de dores e prazeres nos sentimentos de criaturas sensíveis - mas não são todas as operações da natureza levadas adiante por uma oposição de princípios, de quente e frio, húmido e seco, leve e pesado? A conclusão é que a fonte original de todas as coisas é inteiramente indiferente a todos estes princípios, e não tem mais consideração pelo bem sobre o mal do que pelo calor sobre o frio, ou pela secura sobre a humidade, ou pelo leve sobre o pesado.

15. "Podem-se tramar quatro hipóteses sobre as primeiras causas do universo: que elas são dotadas de bondade perfeita, que elas têm uma malícia perfeita, que elas são opostas e têm tanto bondade quanto malícia e que elas não têm bondade nem malícia. Fenômenos mistos jamais podem provar aqueles dois princípios sem mistura. E a uniformidade e constância de leis gerais parecem se opor ao terceiro. $\mathrm{O}$ quarto, portanto, parece de longe o mais provável.

16. “O que eu disse sobre o mal natural se aplicará ao moral com pouca ou nenhuma variação, e não temos mais razão para inferir que a retidão do Ser supremo se assemelha à retidão humana do que sua benevolência se assemelha à humana. Mais ainda, pensar-se-á que temos causa ainda maior para excluir dele sentimentos morais tais como os sentimos, uma vez que o mal moral, segundo a opinião de muitos, é muito mais predominante sobre o bem moral do que o mal natural sobre o bem natural. 
17. "Mas mesmo embora isto não deva ser concedido, e embora a virtude que está no gênero humano deva ser reconhecida como muito superior ao vício, ainda assim, na medida em que há qualquer vício no universo, vos embaraçará muito, antropomorfistas, explicar isto. Tereis que assinalar uma causa para isto sem recurso à primeira causa. Mas como todo efeito tem que ter uma causa, e esta causa ter uma outra, tereis ou que levar adiante a progressão in infinitum, ou permanecer naquele princípio original que é a causa última de todas as coisas..."

18. "Para! Para!", gritou DÊMEAs. "Para onde tua imaginação te precipita? Aliei-me a ti a fim de provar a natureza incompreensível do Ser divino e refutar os princípios de CLEANTES, que mediria todas as coisas por uma regra e padrão humanos. Mas agora te vejo correndo por todos os tópicos dos maiores libertinos e infiéis, e traindo aquela causa sagrada que aparentemente desposaste. És secretamente, então, um inimigo mais perigoso do que o próprio CleANTES?"

19. "E te atrasas tanto em perceber isto?", replicou Cleantes. "Crê em mim, Dêmeas, teu amigo FILÃo desde o começo tem se divertido às nossas custas, e deve-se confessar que o raciocínio injudicioso de nossa ${ }^{36}$ teologia vulgar apenas lhe deu corda para radicalizar justissimamente. A debilidade total da razão humana, a absoluta incompreensibilidade da natureza divina, a miséria grande e universal e a perversidade maior ainda dos homens estes são certamente tópicos estranhos para serem cuidados por teólogos e doutores ortodoxos. Em eras de estupidez e ignorância, de fato, estes princípios podem seguramente ser desposados; e talvez nenhuma visão das coisas seja mais própria para promover a superstição do que aquela que encoraja a pasmaceira cega, a desconfiança e melancolia da espécie humana. Mas agora..."

36 Hume parece ter omitido acidentalmente um y, transformando de your (tua) em our (nossa). 
20. "Não culpes tanto", disse FILÃo, "a ignorância desses cavalheiros reverendos. Eles sabem como mudar seu estilo junto com os tempos. Antigamente era o tópico teológico mais popular defender que a vida humana era vaidade e miséria e exagerar todos os males e dores que aconteceram aos homens. Mas em anos tardios, teólogos, vemos, começam a desdizer essa posição e defender, embora ainda com alguma hesitação, que há mais bens do que males, mais prazeres do que dores, mesmo nesta vida. Esta variação é a mesma (e advinda das mesmas causas) que apontei antes a respeito do ceticismo."

21. Assim FILÃo manteve até o fim seu espírito de oposição e sua censura das opiniões estabelecidas. Mas eu pude observar que DÊMEAS não gostou de modo algum da última parte do discurso, e teve ocasião logo depois, com um pretexto ou outro, de deixar a companhia. 


\section{习arte XII}

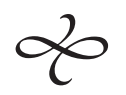

1. Após a partida de Dêmeas, Cleantes e Filão continuaram a conversa da seguinte maneira: "Nosso amigo, receio," disse CleANTES, "terá pouca inclinação a reviver este tópico de discurso enquanto estiveres na companhia; e para falar a verdade, FILÃo, eu devo preferir raciocinar com cada um de vós à parte sobre esse assunto tão sublime e tão interessante. Teu espírito de controvérsia, aliado a tua abominação a superstição vulgar, te leva a alcances estranhos quando engajado num argumento; e não há nada tão sagrado e venerável, mesmo aos teus próprios olhos, que poupes nessa ocasião."

2. "Devo confessar", disse FILÃo, "que sou menos cauteloso neste assunto da religião natural do que em qualquer outro, tanto porque sei que nunca poderei, neste ponto, corromper os princípios de qualquer homem de senso comum, quanto porque ninguém, aposto, a cujos olhos eu pareça um homem de senso 
comum, jamais confundirá minhas intenções. Tu em particular, Cleantes, com quem vivo numa intimidade sem reservas, tu sabes que, malgrado a liberdade da minha conversa e o meu amor aos argumentos singulares, ninguém tem um senso de religião mais forte gravado na mente ou presta adoração mais profunda ao Ser divino tal como ele se desvela para a razão no inexplicável engendro e artifício da natureza. Um propósito, uma intenção, um desígnio por toda parte arrebata o mais descuidado, o mais estúpido pensador, e nenhum homem é capaz de estar tão enrijecido em sistemas absurdos a ponto de sempre rejeitá-lo. Que 'a natureza nada faz em vão' é uma máxima estabelecida em todas as escolas a partir da mera contemplação dos trabalhos da natureza, sem qualquer propósito religioso; e, pela firme convicção de sua verdade, um anatomista que tenha observado um novo órgão ou canal jamais se satisfaria até que descobrisse também o seu uso e intenção. Um grande fundamento do sistema COPERNICANO é a máxima de que 'a natureza age pelos métodos mais simples e escolhe os meios mais próprios para qualquer fim', e os astrônomos muitas vezes, sem pensarem nisto, lançam este forte fundamento da piedade e da religião. A mesma coisa é observável noutras partes da filosofia: E assim todas as ciências quase nos levam a reconhecer insensivelmente um primeiro Autor inteligente, e sua autoridade muitas vezes é maior à medida que não professam diretamente aquela intenção.

3. "É com prazer que ouço GALENO raciocinar sobre a estrutura do corpo humano. A anatomia dum homem, diz ele, desvela mais de 600 músculos diferentes, e quem quer que os considere devidamente verá que em cada um deles a natureza tem que ter ajustado ao menos dez circunstâncias diferentes para lograr o fim a que ela se tinha proposto: figura própria, magnitude justa, disposição certa dos vários fins, posição do todo mais acima e mais abaixo, a inserção devida dos vários nervos, veias e artérias; então, em músculos apenas, mais de 6.000 considerações e in- 
tenções têm de ter sido formadas e executadas. Os ossos ele calcula que sejam 284 - os propósitos distintos, visados na estrutura de cada um, mais de quarenta. Que prodigiosa manifestação de artifício, mesmo nestas partes simples e homogêneas! Mas se considerarmos a pele, os ligamentos, os vasos, as glândulas, os humores, os vários membros do corpo, o quanto não deverá a nossa pasmaceira nos ir tomando, à proporção do número e da complexidade das partes ajustadas com tanta artificiosidade? Quanto mais avançamos nessas pesquisas, mais descobrimos cenas de arte e sabedoria. Mas avistamos ainda, a certa distância, cenas mais remotas além do nosso alcance: na fina estrutura das partes, na economia do cérebro, na trama dos vasos seminais. Todos estes artifícios são repetidos em toda espécie diferente de animal com variedade maravilhosa e, com propriedade exata, adequadas às diferentes intenções da natureza ao forjar cada espécie. E se a infidelidade de GaLENo, mesmo quando essas ciências naturais eram tão imperfeitas, não pôde resistir a tais aparências arrebatadoras, a que grau de teimosia pertinaz um filósofo desta era tem que ter chegado para poder duvidar agora duma inteligência suprema?

4. "Pudesse eu me encontrar com algum desta espécie (que, graças a Deus, é muito rara), lhe perguntaria: Supondo que houvesse um Deus que não se desvelasse imediatamente para os nossos sentidos, ser-lhe-ia possível dar provas mais fortes de sua existência do que o que aparece por toda a face da natureza? O que, de fato, poderia tal Ser divino fazer além de copiar a presente economia das coisas, tornar muitos dos seus artifícios tão claros que nenhuma estupidez poderia os confundir, conferir vislumbres de artifícios ainda maiores que demonstram sua prodigiosa superioridade sobre nossas apreensões estreitas e ocultar completamente boa parte para tais criaturas imperfeitas? Ora, de acordo com todas as regras de raciocínio justo, todo fato tem que passar por inconteste quando é sustentado por todos os ar- 
gumentos que a natureza admite, mesmo que esses argumentos não sejam, em si, muito numerosos e forçosos. $\mathrm{O}$ quão mais no presente caso, onde a imaginação humana não pode computar o seu número e nenhum entendimento estimar a sua consistência?"

5. "Devo acrescentar", disse Cleantes, "ao que tão bem levantaste, que uma grande vantagem do princípio do teísmo é a de ser o único sistema de cosmogonia que pode se tornar inteligível e completo e ainda poder a cada passo preservar uma analogia forte com o que vemos e experimentamos todos os dias no mundo. A comparação do universo a uma máquina de engendro humano é tão óbvia e natural, e é justificada por tantos exemplos de ordem e desígnio na natureza, que arrebata imediatamente toda apreensão sem preconceitos e obtém aprovação universal. Quem quer que tente enfraquecer essa teoria não poderá pretender êxito estabelecendo em seu lugar qualquer outra que seja precisa e determinada: à pessoa que o tente bastará, se ela levantar dúvidas e dificuldades, alcançar através de concepções remotas e abstratas das coisas aquela suspensão de juízo, que é aqui o limite mais extremo de seus desejos. Mas, além de este estado de mente ser em si mesmo insatisfatório, nunca pode ser mantido com firmeza contra tais aparências arrebatadoras, que continuamente nos conduzem à hipótese religiosa. A um sistema falso, absurdo, a natureza humana pela força do preconceito é capaz de aderir com teimosia e perseverança - mas nenhum sistema em oposição a uma teoria sustentada por razão forte e óbvia, por propensão natural e por educação precoce, creio possível de ser mantido ou defendido."

6. "Estimo tão pouco", disse FILÃO, "possível esta suspensão de juízo no presente caso, que sou capaz de suspeitar que aí entra algo de disputa de palavras nessa controvérsia, mais do que comumente se imagina. Que os trabalhos da natureza sustentam uma grande analogia com as produções da arte, é evidente; e de acordo com todas as regras do bom raciocinar, devemos inferir, 
se discutimos mesmo a respeito deles, que suas causas têm uma analogia proporcional. Mas como há também diferenças consideráveis, temos razão para supor uma diferença proporcional nas causas, e em particular devemos atribuir um grau muito mais alto de poder e energia à causa suprema do que qualquer um que jamais observamos na espécie humana. Aqui, então, uma DeIDADE é claramente descoberta pela razão, e se pusermos em questão se, por conta dessas analogias, podemos chamá-la mente ou inteligência malgrado a vasta diferença que pode ser razoavelmente suposta entre a sua mente e as humanas, o que é isto se não uma mera controvérsia verbal? Nenhum homem pode negar as analogias entre os efeitos; restringirmo-nos a investigar as causas dificilmente é possível: por esta investigação, a conclusão legítima é que as causas também têm analogia. E se não estamos contentes em chamar a causa primeira e suprema de Deus ou DeIDADE, mas desejamos variar a expressão, de que podemos chamá-la senão MENTE ou PENSAMENTO, com os quais se supõe com justeza que ela mantenha uma semelhança considerável?

7. ${ }^{37}$ "Todos os homens de razão sã ficam aborrecidos com disputas verbais, que tanto abundam em investigações filosóficas e teológicas; e tem-se visto que o único remédio para este abuso deve surgir de definições claras, da precisão daquelas ideias que tomam lugar em qualquer argumento, e do uso estrito e uniforme daqueles termos que são empregados. Mas há uma espécie de controvérsia que, pela natureza mesma da linguagem e ideias humanas, está envolta numa ambiguidade perpétua que nunca pode, por quaisquer precauções e definições, ser capaz de alcançar uma certeza ou precisão razoáveis. Estas são as controvérsias acerca do grau de qualquer qualidade ou circunstância. Os homens podem discutir por toda a eternidade se ANíBAL era um grande, um grandíssimo ou um superlativamente grande homem, qual grau de beleza CleópATRA possuía, de qual epíteto

37 Este parágrafo foi acrescentado na revisão final de 1776, ano da morte do autor. 
Lívio ou Tucídides é digno, sem trazerem a controvérsia a qualquer determinação. Os disputantes podem aqui concordar no sentido e diferir nos termos, ou vice-versa, ou ainda não serem capazes de definir seus termos de modo a introduzirem-se um ao que o outro quer dizer - porque os graus dessas qualidades não são, como quantidade ou número, suscetíveis a mensurações exatas que possam servir de padrão na controvérsia. Que a disputa acerca do teísmo é desta natureza, e portanto é meramente verbal ou talvez, se possível, ainda mais incuravelmente ambígua, ver-se-á com a investigação mais tênue. Pergunto ao teísta se ele não admite que há uma diferença grande, incomensurável porque incompreensível, entre a mente humana e a divina - quanto mais pio ele for, mais prontamente assentirá à afirmativa e mais estará disposto a aumentar essa diferença: ele asserirá mesmo que a diferença é duma natureza que não pode ser muito aumentada. Em seguida volto-me para o ateu que, assiro, é-o apenas em nome e nunca pode sê-lo a sério, e pergunto-lhe se, pela aderência mútua e concórdia aparente de todas as partes deste mundo, não há certo grau de analogia entre todas as operações da natureza, em toda situação e em toda era; se o apodrecimento dum nabo, a geração dum animal, a estrutura do pensamento humano não são energias que provavelmente sustentem alguma analogia remota entre si. É impossível que ele negue isto. Prontamente o reconhecerá. Tendo obtido esta concessão, empurro-o ainda para mais longe em sua retirada e pergunto-lhe se não é provável que o princípio que arranjou primeiramente e ainda mantém ordem no universo não sustente alguma remota e inconcebível analogia com outras operações da natureza, e sobretudo com a economia da mente humana e pensamento. Por mais que relute, terá que dar seu assentimento. Onde então, brado eu para ambos os antagonistas, está o assunto de vossa disputa? O teísta admite que a inteligência original é bem diferente da razão humana; o ateu, que o princípio de ordem sustenta alguma analogia remota com 
isto. Arranjareis querelas, cavalheiros, quanto a graus, e entrareis numa controvérsia que não admite qualquer significado preciso e tampouco, consequentemente, qualquer determinação? Se fordes tão teimosos, não me surpreenderei se eu vos vir mudando de partido, enquanto o teísta por um lado exagera na dessemelhança entre o Ser supremo e criaturas frágeis, imperfeitas, variáveis e mortais, e o ateu por outro aumenta a analogia entre todas as operações da natureza em todo período, toda situação e toda posição. Considerai então onde o real ponto de controvérsia jaz, e se não puderdes deixar de lado vossas disputas, tentai ao menos curar-vos de vossa animosidade.

8. "E aqui tenho também de reconhecer, ClEANTES, que como os trabalhos da natureza têm uma analogia muito maior com os efeitos de nossa arte e engendro do que com os de nossa benevolência e justiça, temos razões para inferir que os atributos naturais da Deidade têm uma semelhança maior com aqueles dos homens do que sua moral tem com virtudes humanas. Mas qual é a consequência? Nada além disto: que as qualidades morais do homem são mais defectivas neste tipo do que suas habilidades naturais. Afinal, como o Ser supremo é admitido como sendo absoluta e inteiramente perfeito, o que quer que difira mais dele se aparta mais do padrão supremo de retidão e perfeição.*

\footnotetext{
Parece evidente que a disputa entre céticos e dogmáticos é inteiramente verbal, ou ao menos diz respeito apenas aos graus de dúvida e certeza que devemos dispensar a todos os raciocínios - e tais disputas comumente são no fundo verbais e não admitem qualquer determinação precisa. Nenhum dogmático filosófico nega que há dificuldades acerca tanto dos sentidos quanto de todas as ciências, e que estas dificuldades sejam, num método regular e lógico, absolutamente insolúveis. Nenhum cético nega que estamos sob uma necessidade absoluta, apesar dessas dificuldades, de pensar e crer e raciocinar sobre todo tipo de assunto, e mesmo de frequentemente assentir com confiança e segurança. A única diferença, então, entre estas seitas, se elas merecem este nome, é que o cético, por hábito, capricho ou inclinação, insiste mais nas dificuldades; o dogmático, por razões semelhantes, na necessidade. [Esta nota, riscada e reescrita, foi acrescentada entre 1751 e 1763.]
} 
9. “Estas, Cleantes, são as minhas opiniões sinceras a respeito deste assunto, e estas opiniões, sabe-lo, sempre acalentei e mantive. Mas em proporção à minha veneração à religião verdadeira está a minha abominação às superstições vulgares, e sinto um prazer peculiar, confesso, em empurrar tais princípios às vezes para a absurdidade, às vezes para a impiedade. E estás cônscio de que todos os carolas, malgrado sua maior aversão à última do que à primeira, são em geral igualmente culpados de ambas."

10. "Minha inclinação", replicou Cleantes, "se situa, admito, de modo contrário. Religião, por mais que corrupta, ainda é melhor do que religião nenhuma. A doutrina de um estado futuro é uma segurança tão forte e necessária à moral que nunca a devemos abandonar ou negligenciar. Afinal, se recompensas e castigos finitos e temporários têm um efeito tão grande como o que vemos diariamente, o quão maior deve ser o esperado daquele que seja infinito e eterno?"

11. "Então como acontece", disse FILÃo, "se a superstição ${ }^{38}$ vulgar for tão salutar à sociedade, de toda a História abundar tanto de descrições de suas consequências perniciosas nos negócios públicos? Facções, guerras civis, perseguições, subversões ao governo, opressão, escravidão: estas são as consequências desoladoras que sempre acompanham sua prevalência sobre as mentes dos homens. Se o espírito religioso alguma vez for mencionado em qualquer narrativa histórica, ficaremos certos de encontrar depois com detalhes as misérias que o acompanham. E nenhum período pode ser mais feliz ou mais próspero do que aquele em que nunca se vê ou se ouve tal espírito."

12. "A razão desta observação", replicou Cleantes, "é óbvia. O ofício próprio da religião é regular o coração dos homens, humanizar sua conduta, infundir o espírito de temperança, ordem e obediência; e como sua operação é silenciosa, e apenas reforça os motivos de moralidade e justiça, ela corre perigo de ser negli-

38 Em rasura feita entre 1751 e 1763, "superstição" substituiu "religião". 
genciada e confundida com este ou aquele motivo. Quando ela se distingue e age sobre os homens como um princípio separado, ela se apartou de sua esfera própria e se tornou apenas um disfarce para facção e ambição."

13. "E assim será toda religião", disse FILÃo, "exceto a do tipo filosófico e racional. Teus raciocínios são mais facilmente eludidos do que os meus fatos. Esta inferência não é justa: 'porque recompensas e punições finitas e temporárias têm influência tão grande, tais, se infinitas e eternas, têm que tê-la muito maior. ${ }^{\prime 39}$ Considera, rogo a ti, o apego que temos às coisas presentes e a pouca preocupação que constatamos com objetos tão remotos e incertos. Quando teólogos estão declamando contra o comportamento comum e conduta do mundo, sempre representam este princípio como o mais forte que se possa imaginar (como de fato o é) e descrevem quase toda a espécie humana como estando sob sua influência e mergulhada na mais profunda letargia e indiferença aos seus interesses religiosos. Ainda os mesmos teólogos, quando refutam seus antagonistas especulativos, supõem serem os motivos da religião tão poderosos que, sem eles, seria impossível à sociedade subsistir - e nem se envergonham de contradição tão palpável. É certo, pela experiência, que o menor grão de honestidade e benevolência naturais têm mais efeito sobre a conduta dos homens do que as considerações mais pomposas sugeridas por teorias e sistemas teológicos. Certa inclinação natural do homem trabalha incessantemente sobre ele,

39 Há aqui uma passagem riscada: “Se de fato considerarmos a questão a uma luz meramente abstrata, se compararmos apenas a importância dos motivos e em seguida refletirmos sobre o instinto de autopreservação [self-love] da espécie humana, devemos não apenas procurar um efeito maior a partir de considerações religiosas, mas devemos estimá-las absolutamente irresistíveis e infalíveis em sua operação. Pois qual outro motivo pode contrabalançá-las razoavelmente mesmo por um momento? Mas não se vê isto se sustentar na realidade; e, portanto, podemos estar certos de que há algum outro princípio da natureza humana, o qual negligenciamos aqui, e que ao menos diminui a força desses motivos. Este princípio é o apego que temos, \&c." 
está sempre presente na mente e se mescla com cada aspecto e consideração - ao passo que motivos religiosos, quando agem mesmo, operam apenas por motores e limites, e dificilmente lhes é possível tornarem-se de todo habituais para a mente. A força da maior gravidade, dizem os filósofos, é infinitamente pequena em comparação ao menor impulso; ainda assim, é certo que a menor gravidade irá, por fim, prevalecer sobre um grande impulso porque nenhum golpe ou pancada pode ser repetido com tanta constância quanto a da atração e da gravitação. ${ }^{40}$

14. "Outra vantagem da inclinação: por seu lado, ela se compromete com toda agudeza e engenhosidade da mente, e quando posta em oposição a princípios religiosos, procura todo método ou arte ao eludi-los - em que ela é quase sempre exitosa. Quem pode explicar o coração dum homem ou aquelas estranhas salvas e desculpas com as quais as pessoas se satisfazem quando seguem suas inclinações, em oposição ao seu dever religioso? Isto se entende muito bem no mundo, e ninguém senão os tolos jamais deposita menos confiança num homem porque ele entreteve algumas dúvidas especulativas a respeito de assuntos teológicos. E quando temos que lidar com um homem que faz grande profissão de religião e devoção, isto tem outro efeito sobre os vários que passam por prudentes, que não o de colocá-los em guarda para que não sejam passados para trás e enganados por ele?

15. “Devemos ir mais longe e considerar que filósofos que cultivam a razão e a reflexão têm menos necessidade de tais motivos para se manterem sob as restrições da moral, e que o vulgo, o único que pode precisar disso, é maximamente incapaz duma religião tão pura como a que representa a Deidade se agradando com nada além da virtude no comportamento humano. As recomendações à Divindade em geral se supõem ou observâncias frí-

40 Hume também discute este assunto na seção XIV da História natural da religião. 
volas, ou êxtases enlevados, ou ainda credulidade carola. ${ }^{41}$ Não precisamos voltar à Antiguidade ou errar por regiões remotas para encontrar exemplos dessa degenerescência. Entre nós mesmos, alguns foram culpados daquela atrocidade, desconhecida pelas superstições EGíPCIAS e GREGAS, de declamar em termos expressos contra a moralidade e representá-la como perda certeira do favor divino, como se o mais ínfimo crédito ou confiança depositasse nisto.

16. "Mas, mesmo que a superstição ou o entusiasmo não se coloquem em direta oposição à moralidade, o próprio desvio da atenção, o surgimento duma nova e frívola espécie de mérito, a distribuição grotesca que ela faz de elogio e culpa, têm que ter as consequências mais perniciosas e enfraquecido extremamente o apego dos homens aos motivos naturais de justiça e humanidade.

17. "Do mesmo modo, tal princípio de ação, não sendo nenhum dos motivos familiares da conduta humana, age sobre o temperamento apenas por intervalos e tem que ser excitado por esforços contínuos para deixar o pio zelote satisfeito com a própria conduta e fazê-lo completar sua devota tarefa. Muitos exercícios religiosos são introduzidos com fervor aparente onde o coração, no momento, se sente frio e lânguido: um hábito de dissimulação é gradualmente contraído, e fraude e falsidade viram o princípio predominante. Daí a observação vulgar ${ }^{42}$ de que o mais alto zelo em religião e a mais profunda hipocrisia, longe

41 Entre 1751 e 1763, Hume riscou o trecho que vai deste ponto até o fim do parágrafo, e depois acrescentou à margem: "Imprime esta passagem".

42 Em rasura, "observação vulgar" substituiu "fenômeno comum". Vale confrontar essas observações sobre o caráter do fiel com a última entrevista de David Hume, concedida a Boswell: "Ele disse então categoricamente que a moralidade de toda religião era má, e de fato não acho que zombava quando disse que quando ouvia que um homem era religioso, concluía que era um canalha, embora conhecesse alguns exemplos de homens muito bons que fossem religiosos." (DNR, ed. Kemp Smith, p. 76) 
de serem incompatíveis, estão frequente ou comumente unidas no mesmo caráter individual.

18. "Os efeitos malévolos de tais hábitos, mesmo na vida comum, são imaginados facilmente - mas onde os interesses da religião são concernidos, nenhuma moralidade pode ser forte o bastante para limitar o zelote entusiasmado. A sacralidade da causa santifica qualquer medida que se possa usar para promovê-la.

19. "Só a atenção fixa num interesse tão importante como o da salvação eterna é capaz de extinguir as afecções benevolentes e engendrar um egoísmo estreito, contraído. E quando tal temperamento é encorajado, elude facilmente todos os preceitos gerais de caridade e benevolência.

20. "Assim, os motivos da superstição vulgar não têm grande influência sobre a conduta geral, e tampouco é sua operação muito favorável à moralidade nas situações em que predominam.

21. "Há alguma máxima em política mais certeira e infalível do que a de que tanto o número quanto a autoridade dos sacerdotes devem ser confinados em limites bem estreitos e que os magistrados civis devem, para sempre, manter seus fasces e axes $^{43}$ longe de tais mãos perigosas? No entanto, se o espírito da religião popular fosse tão salutar à sociedade, uma máxima contrária deveria prevalecer. Quanto maior fosse o número de sacerdotes, sua autoridade e sua riqueza, maior seria sempre o espírito religioso. E embora os sacerdotes tenham a liderança deste espírito, por que não podemos esperar uma santidade superior na vida e maiores benevolência e moderação das pessoas que são reservadas à religião, que a estão continuamente inculcando nos outros e que têm que absorver dela uma parte maior? Donde vem então que, na verdade, o máximo que um magistrado sábio pode propor a respeito das religiões populares é, na medida do possível, fazer para elas um estratagema eco-

$43 \quad \mathrm{Na}$ Roma antiga, símbolos do poder político. 
nômico e prevenir suas consequências perniciosas à sociedade? Todo expediente que ele tente para um propósito tão humilde é cercado por inconveniências: Caso admita apenas uma religião entre os seus súditos, terá de sacrificar a uma incerta perspectiva de tranquilidade toda consideração pela liberdade, ciência, razão, indústria públicas e mesmo sua própria independência. Caso seja indulgente com várias seitas, o que é a máxima mais sábia, terá de preservar uma indiferença bem filosófica por todas a elas e cuidadosamente restringir as pretensões da seita prevalecente; do contrário, não poderá esperar nada além de intermináveis disputas, querelas, facções, perseguições e comoções civis.

22. "A religião verdadeira, admito, não tem tais consequências perniciosas. Mas devemos tratar a religião do modo como ela comumente ${ }^{44}$ se achou no mundo; e não tenho o que fazer com aquele preceito especulativo de teísmo que, como é uma espécie de filosofia, tem de partilhar da influência benéfica daquele princípio e, ao mesmo tempo, tem que estar sob uma inconveniência de peso semelhante, a de confinar-se sempre a pouquíssimas pessoas. ${ }^{45}$

23. "Juramentos são necessários em todas as cortes de judicatura, mas é questionável se sua autoridade advém dalguma religião popular. São a importância e solenidade da ocasião, o cuidado com a reputação e a reflexão sobre os interesses gerais da sociedade, que são as principais contenções da espécie humana. Juramentos alfandegários e juramentos políticos são no entanto pouco estimados mesmo por alguns que pretendem os

44 Em rasura feita entre 1751 e 1763, "comumente" substituiu "sempre".

45 Aqui foi feito este acréscimo que depois foi riscado: “Uma vez que governo, razão, estudo, amizade, amor e toda vantagem humana é acompanhada por inconvenientes, como vemos diariamente, o que não deve ser esperado de todos os vários modelos de superstição, uma qualidade composta do que há de mais absurdo, corrupto e bárbaro da nossa natureza? Houvesse uma exceção a essa mistura universal de bem e mal que se acha na vida, esta poderia ser declarada total e inteiramente má." 
princípios de honestidade e religião: a asseveração dum quacre é por nós posta em pé de igualdade com o juramento de qualquer outra pessoa. Sei que POLÍBIO* atribui a infâmia da fé GREGA à prevalência da filosofia EPICURISTA, mas sei também que a fé PÚNICA teve uma reputação tão má em tempos antigos quanto o testemunho IRLANDÊS tem em tempos modernos, embora não possamos explicar essas observações vulgares pela mesma razão. Isto para não mencionar que a fé GREGA era infame antes do surgimento da filosofia EPICURISTA, e que EURíPIDES ${ }^{*}$, numa passagem que devo mostrar-te, vislumbrou um notável golpe de sátira contra sua nação a respeito dessa circunstância."

24. "Toma cuidado, FILÃo", replicou Cleantes, "toma cuidado: não leva tão adiante as questões, não permite que teu zelo contra a falsa religião mine tua veneração pela verdadeira. Não te prives deste princípio, o principal, o único grande conforto na vida, e o nosso principal alento em meio a todos os ataques da fortuna adversa. A mais agradável reflexão que a imaginação humana pode sugerir é aquela do teísmo genuíno, que nos representa como obra dum Ser perfeitamente bom, sábio e poderoso que nos criou para a felicidade e que, tendo implantado em nós imensuráveis desejos de bem, prolongará nossa existência por toda a eternidade e nos transferirá para uma variedade de cenas a fim de satisfazer aqueles desejos e tornar nossa felicidade completa e durável. Depois de tal Ser mesmo (se a comparação for permitida), o quinhão mais feliz que podemos imaginar é aquele de estar sob sua guarda e proteção."

25. "Estas aparências", disse FILÃo, "são as mais cativantes e fascinantes; e, para o verdadeiro filósofo, elas são mais do que aparências. Mas acontece aqui, como no caso anterior, que para a maior parte da espécie humana as aparências são enganosas e os terrores da religião comumente prevalecem sobre seus confortos.

* Lib. 6, cap. 54.

* Iphigenia in Tauride. 
26. "Admite-se que os homens nunca têm recurso à devoção tão prontamente quanto quando desalentados pelo pesar ou deprimidos pela doença. Isto não é uma prova de que o espírito religioso não se alia com tanta estreiteza à alegria como à dor?"

27. "Mas os homens, quando aflitos, encontram consolo na religião", replicou Cleantes. "Algumas vezes", disse FILÃo, "Mas é natural imaginar que formem uma noção daqueles seres desconhecidos de modo adequado ao sorumbatismo e melancolia presentes no temperamento quando se devotam à sua contemplação. Por conseguinte, vemos as imagens terríveis predominarem em todas as religiões; e nós mesmos, depois de termos empregado as mais exaltadas expressões em nossas descrições da Deidade, caímos na contradição mais clara ao afirmarmos que os danados são infinitamente superiores em número aos eleitos.

28. "Atrever-me-ei a afirmar que nunca houve uma religião popular que representasse o estado das almas defuntas a uma luz que tornasse preferível à espécie humana que ele exista. Aqueles modelos agradáveis de religião são os meros produtos de filosofia. Afinal, como a morte reside entre o olho e a perspectiva da futurição, é tão chocante para a natureza que deve lançar melancolia a todas as regiões que residem além dela e sugerir à generalidade da espécie humana a ideia de CÉRBERO e FúrIAS, demônios e torrentes de fogo e enxofre.

29. "É verdade: tanto o medo quanto a esperança entram na religião, porque ambas estas paixões, em tempos diferentes, agitam a mente humana e cada uma delas forma uma espécie de divindade que lhe seja adequada. Mas quando o homem está numa disposição alegre, fica pronto para negócios ou companhia ou entretenimento de qualquer tipo - e naturalmente se aplica a isto, não pensa em religião. Quando melancólico e desalentado, nada tem a fazer senão matutar sobre os terrores do mundo invisível e afundar-se ainda mais em aflição. De fato, poderá talvez acontecer de, depois de ter gravado desta maneira as opiniões 
religiosas profundamente no seu pensamento e imaginação, chegar uma mudança de saúde ou das circunstâncias que restaurem seu bom-humor e, levantando perspectivas alegres de futurição, faça-o correr para o outro extremo de alegria e triunfo. Mas deve-se reconhecer que, como o terror é o princípio primário da religião, é a paixão que sempre predomina nela e admite apenas intervalos curtos de prazer.

30. "Isto para não mencionar que estes acessos de alegria excessiva, entusiástica, ao exaurirem os espíritos sempre preparam o caminho para igual acesso de terror e desalento supersticiosos; e tampouco há algum estado de mente tão feliz quanto o calmo e sereno. Mas é impossível manter este estado quando o homem pensa que jaz em tal incerteza e escuridão profundas, entre uma eternidade de felicidade e uma eternidade de miséria. Não é de admirar que tal opinião desconjunte a constituição original da mente e a lance à mais extrema confusão. E embora essa opinião dificilmente seja tão firme em sua operação de modo a influenciar todas as ações, ainda assim é capaz de fazer uma fenda considerável no temperamento e de produzir aquele sorumbatismo e melancolia tão notáveis em todo povo devoto.

31. "É contrário ao senso comum entreter apreensões ou terrores por conta de qualquer opinião, ou imaginar que corremos algum risco na vida futura pelo uso mais livre de nossa razão. Isto implica tanto uma absurdidade quanto uma inconsistência. É uma absurdidade crer que a Deidade tenha paixões humanas, e uma das paixões humanas mais baixas: um incansável apetite por aplausos. É uma inconsistência crer que, uma vez que a Deidade tem essa paixão humana, ela não tenha outras também; e, em particular, um desprezo pelas opiniões de criaturas tão inferiores. 
32. ${ }^{46}$ “'Conhecer Deus', diz SÊNECA, 'é adorá-lo'47. Toda outra adoração é de fato absurda, supersticiosa e mesmo ímpia. Degrada-o à condição baixa da espécie humana, que se apraz com súplicas, solicitações, presentes e bajulação. Ainda assim, esta impiedade é o mais ínfimo do que a superstição é culpada. Comumente, degrada a Deidade bem abaixo da condição do gênero humano e a representa como um Demônio caprichoso que exerce seu poder sem razão nem humanidade! E fosse tal Ser divino disposto a ofender-se com os vícios e besteiras dos tolos mortais que são sua obra, decerto passaria mal com os fiéis da maioria das superstições populares. E ninguém da raça humana mereceria seu favor além duns pouquíssimos: os teístas filosóficos, que entretêm, ou antes tentam entreter, noções adequadas de suas perfeições divinas. Assim como as únicas pessoas dignas de sua compaixão e indulgência seriam os céticos filosóficos, uma seita quase igualmente rara que, por uma desconfiança natural de sua própria capacidade, suspendem ou tentam suspender todo juízo a respeito de assuntos de tal modo sublimes e extraordinários.

33. ${ }^{48}$ "Se toda a teologia natural, como algumas pessoas parecem sustentar, se resume a uma proposição simples, embora algo ambígua ou ao menos indefinida de que 'a causa ou causas de ordem no universo provavelmente sustenta alguma analogia remota com a inteligência humana', se esta proposição não for capaz de extensão, variação ou explicação mais particular, se ela não fornecer nenhuma inferência que afete a vida humana ou possa ser a fonte de qualquer ação ou proibição, e se a analogia, imperfeita como ela é, não puder ser levada para mais longe do

46 Este parágrafo foi escrito à margem numa revisão entre 1751 e 1763, depois riscado e reescrito junto com o próximo parágrafo na penúltima folha do manuscrito.

47 No volume já aludido, à p. 211, Gaskin diz não ser esta uma citação de Sêneca, mas uma paráfrase bem inexata das Epistulæ morales, 95. 50: "Primus est deorum cultus deos credere", ou seja, a primeira adoração aos deuses é crer neles.

48 Este parágrafo é um acréscimo da revisão final de 1776. 
que a inteligência humana, nem transferida para as outras qualidades da mente com qualquer aparência de probabilidade - se este realmente for o caso, o que poderá o homem mais inquisitivo, contemplativo e religioso fazer além de dar um assentimento pleno, filosófico à proposição, tão frequentemente quanto ela ocorre, e crer que os argumentos sobre os quais está estabelecida excedem as objeções que se lhe opõem? Certa pasmaceira de fato surgirá naturalmente da magnitude do objeto; certa melancolia, da sua obscuridade; certo desprezo pela razão humana, por ela não poder dar uma solução mais satisfatória a respeito duma questão tão grande e magnificente. Mas crê em mim, CleANTES, o sentimento mais natural que uma mente bem disposta terá nesta ocasião é um desejo e expectativa ardentes de que o Céu queira dispersar ou ao menos aliviar esta ignorância profunda fornecendo alguma revelação mais particular à espécie humana e desvelando a natureza, atributos e operações do divino objeto de nossa Fé. Uma pessoa temperada por um justo senso das imperfeições da razão natural correrá com a maior avidez para a verdade revelada, enquanto um dogmatista soberbo, persuadido de que pode erigir um sistema completo de teologia pelo mero auxílio da filosofia, desdenha de qualquer outra ajuda e rejeita esta instrutora adventícia. Ser um cético filosófico é, num homem de letras, o primeiro e mais essencial passo para ser um cristão são, crente: esta é uma proposição que eu de muito bom grado recomendaria à atenção de PÂNFILO, e espero que CleAnTES me perdoe por me interpor tanto na educação e instrução do seu pupilo."

34. Cleantes e Filão não levaram esta conversa muito adiante, e como nada jamais me causou mais impressão do que todos os raciocínios daquele dia, confesso que, por uma séria revisão do conjunto, não posso senão pensar que os princípios de FILÃo são mais prováveis do que os de DÊMEAS, mas que aqueles de CLEANTES estão ainda mais próximos da verdade. 


\section{Cartas de 1 (zume relatívas a as Đíálog̣os}

redigidas à época das revisões 


\title{
I. Carta a Gilbert Elliot de Minto
}

\author{
(L, v. I, p. 150-3)
}

Caro senhor,

Tua noção de corrigir a sutileza de sentimento é certamente muito justa no que diz respeito à moral, que depende de sentimento; mas, nas filosofias política e natural, sempre que uma conclusão for contrária a alguma questão de fato certa, tem certamente de estar errada, e tem de haver algum erro nalgum ponto do argumento - quer tenhamos sido capazes de percebê-lo, quer não ${ }^{49}$. Mas em metafísica ou teologia não posso ver como quaisquer desses parâmetros de verdade claros e óbvios possam ter lugar. Nada aí pode corrigir o mau raciocínio que não o bom raciocínio, e a sofisma deve-se opor silogismo. Observo que, por volta de setenta ou oitenta anos atrás, um princípio como este que desenvolves prevaleceu muitíssimo na França entre alguns filósofos e beaux esprits. Tal ocasião foi esta: o famoso Mons. Nicole de Port Royal, em sua Perpetuité de la Foi, pressionou mui duramente os protestantes quanto à impossibilidade de o povo alcançar uma convicção de sua religião por meio de juízo priva-

49 Aqui Hume é mais claro do que nos Diálogos ao descartar a força do sentimento, da qual se vale o argumento do desígnio. Em raciocínios pretensamente experimentais, não é em sentimento que nos devemos basear, mas em fatos. 
$\mathrm{do}^{50}$, o qual requereu tantas disquisições, raciocínios, pesquisas, erudição, imparcialidade e penetração que, mesmo entre homens de educação, nem uma centena é capaz. Mons. Claude e os protestantes lhe responderam não solucionando suas dificuldades (o que parece impossível), mas replicando-as (o que é facílimo). Mostraram que, enquanto para alcançar o meio da autoridade no qual os católicos insistem, uma série de raciocínio agudo e grande erudição eram requisitos, estes eram suficientes para um protestante. Temos primeiro que provar todas as verdades da religião natural, a fundamentação da moral, a autoridade divina da Escritura, a deferência à Igreja que ela recomenda etc. A comparação desses escritos controversos engendrou a ideia em alguns de que não era nem por raciocínio e nem por autoridade que aprendemos nossa religião, mas por sentimento. E certamente este seria um meio bem conveniente, - e que filósofo não se aprazeria em agir de acordo com ele, se pudesse distinguir sentimento de educação? Mas, para toda aparência, o sentimento de Estocolmo, Genebra, Roma antiga e moderna, Atenas e Mênfis tem as mesmas características. ${ }^{51}$ E nenhum homem pensante pode assentir prontamente a qualquer uma delas senão pelo princípio geral de que, como a verdade nesses assuntos está além da capacidade humana, e que, como para sua própria tranquilidade um homem deve adotar preceitos, há mais satisfação e conveniência em manter o catecismo que nos foi ensinado primeiro. Ora, contra isto nada tenho a dizer. Eu apenas observaria que tal conduta se funda no ceticismo mais universal e determinado, aliado a uma pequena indolência. Afinal, o aumento da curiosidade e da pesquisa fornece uma variante diretamente oposta dos mesmos princípios.

\footnotetext{
50 I.e., raciocínio individual, do próprio fiel.

51 O tópico das semelhanças e regularidades entre as religiões mais diversas é desenvolvido na História natural da religião.
} 
A origem que atribuo à pederastia a partir da frequência dos exercícios ginásticos entre os gregos se funda: (1) No claro testemunho de Cícero. Mas não posso apontar para ti prontamente a passagem. (2) Podemos observar que naquele retrato pleno, natural, indistinto das maneiras antigas feita por Homero em seus dois poemas, não há o mais ínfimo traço desse vício. A amizade entre Aquiles e Pátroclo era pura. Eram ambos homens de meia idade, e Pátroclo era o mais velho. Ademais, Homero cuida em deitá-los à parte, e dá a cada um deles uma rapariga em seus braços. Os gregos mais antigos, portanto, eram livres dessa corrupção. Ora, Tucídides diz que a introdução dos exercícios ginásticos foi tardia. Os primeiros antigos tinham sempre parte dos seus corpos coberta em seus exercícios. (3) Platão diz, repreendendo tanto os bárbaros quanto os gregos asiáticos, que eles eram ignorantes da pederastia e dos exercícios ginásticos. Fala destes como conectados. Embora esta questão seja externa ao meu assunto no Diálogo ${ }^{52}$, acho melhor acrescentar apenas uma nota contendo esses argumentos.

Os gregos parecem antes ter se restringido ao uso $^{53}$ de mulheres. Comércio com uma escrava era reprovável. Mesmo a prostituição, ou comércio com cortesã, era algo escandaloso, e sua punição era tornar o homem incapaz de todo ofício público; no mínimo, não lhe era permitido falar ao Povo. Isto aparece pela oração de Demóstenes contra Androção. Entretanto, reconheço, isto não é reconciliável com muitas passagens na Antiguidade; particularmente, a de que Sólon estabeleceu bordeis públicos por lei. Já anotei esta entre as minhas dúvidas gregas. Encontro Alcibíades muito repreendido por Isócrates por conta de prostituição, mas nunca de pederastia.

52 Trata-se do diálogo que vem anexo à Investigação sobre os princípios da moral.

53 Hume emprega a palavra à maneira dos gregos: $\chi \rho \alpha ́ o \mu \alpha \iota$ pode ser traduzido tanto como "usar" quanto como "fazer sexo com". 
Tenho me divertido ultimamente com um ensaio ou dissertação sobre a população ${ }^{54}$ da Antiguidade, que me levou a muitas disquisições tanto sobre a vida pública quanto a doméstica dos antigos. Tendo lido quase todos os clássicos tanto gregos quanto latinos (uma vez que fiz este plano), extraí o que mais serviu ao meu propósito - mas não tenho nenhum Estrabão, e não sei onde conseguir um nesta vizinhança. É um autor que nunca li. Sei que tua biblioteca (quer dizer, a Dos Advogados) é muito escrupulosa ao emprestar clássicos, mas talvez essa dificuldade possa ser superada. Eu estaria muito obrigado a ti se me pudesses conseguir o empréstimo duma cópia, seja na língua original, ou mesmo numa boa tradução.

Os gregos tinham danças militares, particularmente a Pirrícia, mas não eram praticadas em seus festivais, nem em sua diversão. Seu jeito de dançar era muito bom para um camarada indolente, pois comumente não se levantavam de seus assentos, mas moviam seus braços e cabeças na cadência. É difícil imaginar que houvesse muita graça nesse jeito de dançar.

Mando-te inclusa uma tentativa de chacota $^{55}$ contra algumas pessoas que não gostam muito de que se façam piadas consigo. Frequentemente tive em minhas intenções escrever um suplemento para o Gúliver, contendo o ridículo dos sacerdotes. Foi decerto uma pena que Swift fosse um pároco. Tivesse ele sido um advogado ou médico, teríamos ainda assim nos divertido às expensas dessas profissões. Mas sacerdotes são tão invejosos que não podem ser tocados neste ponto, e por uma razão simples: porque eles são conscientes de que são realmente ridículos. Esta parte do assunto do doutor é tão fértil que um gênio muito inferior, creio, poderia ter êxito.

\footnotetext{
54 I.e., densidade demográfica.

55 Trata-se da seguinte Petição dos Sacristãos, que não consta no volume de cartas. Tirei-a de: PRICE, John Valdimir. The Ironic Hume. Austin: Texas University Press, 1965, p. 173-5.
} 
Fale a Jack Stuart, tão logo que o vejas, que te mandei esta cópia, se ele puder fazer uso dela. Pretendo tê-la impressa; mas não sei como, acho que não vai dar. Se gostares da coisa, desejo que arranjes algum jeito de superar as dificuldades que surgiram da maneira mais estranha do mundo.

Sou, caro senhor, teu o mais sinceramente,

David Hume

Ninewells near Berwick.

18 de fevereiro de 1751 


\section{A petição dos graves e veneráveis sacristãos ou coveiros da Igreja da Escócia à honorável Casa dos Comuns}

Mostra o mais humildemente

Que porquanto o reverendo clero da Igreja da Escócia, movido por um sincero cuidado com a glória de Deus que apareceu tão conspicuamente nos homens de caráter sagrado através de todas as eras, solicitou ao Parlamento um aumento de seus estipêndios,

E porquanto o douto corpo de Mestres-Escola, incitado por seu pio exemplo e movido pelo mesmo cuidado com a glória de Deus, também solicitou ao Parlamento o aumento de seus salários,

E porquanto aprouve à Divina Providência agraciar ambas as solicitações com tal perspectiva segura de sucesso, pode parecer estranho se o grave e venerável corpo de Sacristãos, sendo também pessoas eclesiásticas (embora de caráter inferior), for tão atrasado em sua causa Sagrada e tão negligente com a glória de Deus, mesmo tendo sido convocado pelo ilustre e edificante exemplo de seus superiores.

Os graves e veneráveis Sacristãos, portanto, da Igreja da Escócia, tendo sopesado essas considerações, agora se atrevem a deixar seu caso perante a Casa dos Comuns, sem duvidar de que 
terão a mesma recepção gentil que satisfez o Reverendo Clero e os Doutos Mestres-Escola.

Os Veneráveis Sacristãos clamam por deixar de apoio à petição as seguintes razões:

Pode ser demonstrativamente provado através da Escritura e da razão que a causa da religião se conecta tão íntima e inseparavelmente aos interesses temporais e à grandeza mundana dos seus peticionários quanto à de quaisquer desses eclesiásticos.

Seus peticionários servem na qualidade de coveiros. O grande uso e necessidade de sua ordem, em toda comunidade bem regulada, nunca foi posto em questão por nenhum raciocinador justo - uma vantagem que eles possuem sobre os seus irmãos, o Reverendo Clero.

Sua utilidade é tão extensiva quanto grandiosa, pois mesmo aqueles que negligenciam a religião ou desprezam a erudição têm, ainda assim, nalgum momento, que precisar dos bons trabalhos desta grave e venerável ordem.

Parece impossível que os senhores de terras se oponham aos interesses de seus peticionários ${ }^{56}$, uma vez que, por terem encerrado tão perfeitamente como têm encerrado até agora as pessoas dos pais e irmãos mais velhos dos referidos senhores, seus peticionários são, logo depois dos médicos, as pessoas no mundo às quais os proprietários de terra são mais gratos.

Como seus peticionários são apenas metade eclesiásticos, pode-se esperar que não sejam inteiramente desmedidos nem exorbitantes em suas demandas.

A atual pobreza de seus peticionários neste Reino é um escândalo para toda religião, sendo fácil provar que um Sacristão moderno não é mais ricamente dotado do que um apóstolo primitivo, e, por conseguinte, não possui a vigésima parte da renda de um Pastor Presbiteriano.

56 À época, herdava as terras da família apenas o primogênito. Hume, mesmo, ficara privado de terras. 
Qualquer que seja a liberdade que os profanos zombeteiros e livres-pensadores possam empregar com nossos Reverendos Confrades, o Clero, o mais ousado entre eles treme quando pensa em nós, e uma simples reflexão a nosso respeito reformou mais vidas do que todos os sermões do mundo.

Sendo a música instrumental atribuída a seus peticionários a única deste tipo que sobrou em nossas igrejas verdadeiramente reformadas, é um necessário prelúdio à música vocal do Mestre-Escola e do Ministro, e é por muitos estimada igualmente significativa e melodiosa.

Seus peticionários têm a confiança de que a Casa Honorável não os desprezará por conta da atual mesquinhez de sua condição; pois, tendo ouvido um homem douto dizer que os Cardeais que agora são Príncipes já foram um dia nada mais que curas de paróquia em Roma, observando seus peticionários as mesmas louváveis medidas para serem agora continuadas, não desesperam de um dia se nivelarem à nobreza e senhorios destes domínios.

Que isto portanto agrade, \&c \&c.

\section{Carta a um membro do parlamento com a petição precedente}

Buckhaven, 27 de janeiro de 1751

\section{HONRADO E DIGNO SENHOR,}

Tendo agradado ao Senhor visitar seu povo pecador desta Igreja com muitas e grandes atribulações, foi com consolação que vimos uma espécie de perspectiva "Pisga"57 de dias melhores aberta para nós pelo requerimento dos Reverendos Ministros e Doutos Mestre-Escola por aumento de seus estipêndios e sa-

57 Do cume do monte Pisga, Moisés olhou para a terra prometida. 
lários, e nós, tendo não menos zelo em nossa posição inferior pela mesma causa sagrada, também concordamos com um requerimento por um propósito semelhante - o qual estou autorizado a transmitir-vos pelo meio de comunicação comumente chamado pelos profanos de "correio". Pois não descubro se há um nome evangélico para isto. Se parecer bom aos vossos olhos, depois comungar com vosso coração em prece, seria um fomento a esta obra Divina imprimirdes na cidade grande um número suficiente desta Petição e mandardes que uma seja entregue a cada membro da Casa no mesmo dia da graça em que os Reverendos Ministros devem apresentar sua Petição. Isto poderá, com assistência Divina, adiantar uma obra tão boa, e poderá ser a causa de ambos obterem sucesso - do que estou certo de ambos merecerem igualmente.

Agora, digno e honorável Senhor, se fordes o instrumento do Senhor em seu empreendimento sagrado, eu, por meio deste, vos prometo em meu próprio nome e no de todos os meus confrades que, aquele entre nós a quem o Senhor abençoar com a confortável tarefa de fazer-vos a última obra em nosso poder, o fará tão cuidadosamente que nunca achareis razão para queixar-vos.

Sou,

Honrado e digno senhor,

Vosso amigo e servo no Senhor, Zorobabel M'Gilchrist, Sacristão de Buckhaven. 


\section{Carta a Gilbert Elliot de Minto}

(L, v. I, p. 153-7)

Caro senhor,

Perceberias pela amostra que te dei que faço de Cleantes o herói do Diálogo. O que quer que consigas pensar para fortalecer esse lado do argumento ser-me-á muitíssimo bem-vindo. Qualquer propensão que imagines que eu tenha para o outro lado desmoronou contra a minha vontade - e não foi há muito que queimei um livro manuscrito feito antes dos meus vinte anos, o qual continha, página após página, o progresso gradual dos meus pensamentos sobre este tópico. Começava com uma busca ansiosa por argumentos para confirmar a opinião comum - dúvidas se introduziram, se dissiparam, voltaram, dissiparam-se de novo, e era uma luta perpétua duma imaginação incansável contra a inclinação, talvez até contra a razão.

Amiúde pensei que o melhor jeito de compor um diálogo seria duas pessoas de opiniões diferentes sobre alguma questão de importância escreverem alternativamente as diferentes partes do discurso e replicarem uma à outra. Por este meio evitar-se-ia aquele erro vulgar de se pôr apenas nonsense na boca do adversário $^{58}$, e ao mesmo tempo uma diversidade de caráter e gênio,

58 Isto explica por que Dêmeas e Cleantes têm seus momentos humeanos. 
sendo preservada, faria o conjunto parecer mais natural e menos afetado. Tivesse eu a boa fortuna de viver perto de ti, teria tomado para mim o caráter de Filão no Diálogo, o qual reconhecerás que eu poderia ter sustentado com bastante naturalidade - e tu não serias avesso ao de Cleantes. Acredito, também, que poderíamos os dois ter mantido nossa calma muito bem; bastaria não teres alcançado uma indiferença filosófica absoluta nestes assuntos. ${ }^{59}$ Que perigo pode vir de raciocínio e investigação engenhosos? O pior cético especulativo que já conheci foi um homem muito melhor do que o melhor devoto e carola supersticioso. Devo informar-te, também, que esta era a maneira de pensar dos antigos neste assunto. Se um homem fez profissão de filosofia, qualquer que fosse sua seita, eles sempre esperavam encontrar mais regularidade em sua vida e maneiras do que nas dos ignorantes e iletrados. Há uma passagem notável de Apiano a este propósito: este historiador informa que, não obstante o estabelecido preconceito a favor da boa instrução, ainda assim alguns filósofos aos quais foi confiado poder absoluto abusaram muito deste; e ele se baseia muito em Crítias, o mais violento dos Trinta, e em Aristão, que governou Atenas no tempo de Silas. No entanto descubro, com base em investigação, que Crítias era um ateu professo; e Aristão, um epicurista - o que era pouco ou nada diferente. E ainda assim Apiano se espanta com sua corrupção tanto quanto se eles tivessem sido estoicos ou platônicos. Um zelote moderno teria pensado que essa corrupção era inevitável.

59 Reproduzo traduzida a nota do editor destas cartas, J. Y. T. Greig: “Elliot nunca alcançou indiferença nesses pontos. Ele foi ancião líder na Igreja da Escócia, e de acordo com Thomas Somerville, que se tornou ministro em Minto em 1767: 'Quanto à religião e à moral, sempre professou e inculcou os sentimentos mais corretos e puros. Expressou uma acentuada reprovação à filosofia cética inculcada com sutileza e elegância ímpares na obra de David Hume, àquela época universalmente lida e comumente admirada.' (My own Life and Times, 122)" 
Eu queria que o argumento de Cleantes fosse analisado de modo a tornar-se bem formal e regular. A propensão da mente em direção a ele, a menos que essa propensão seja tão forte e universal quanto a de acreditar em nossos sentidos e experiências, ainda será, receio, estimada uma fundamentação suspeita. É aqui que desejo a tua assistência: temos ${ }^{60}$ de tentar provar que essa propensão é dalguma maneira diferente da nossa inclinação de achar nossas próprias figuras nas nuvens, nossa face na lua, nossas paixões e sentimentos até em matéria inanimada. Tal inclinação pode e deve ser controlada, e jamais poderá ser um fundamento legítimo para o assentimento.

Os exemplos que escolhi para Cleantes são, espero, toleravelmente felizes, e a confusão em que represento o cético parece natural. Mas si quid novisti rectius, etc. ${ }^{61}$

Perguntas-me: "Se a ideia de causa e efeito é apenas vizinhança" (deverias ter dito vizinhança constante ou conjunção regular) "eu saberia de bom grado donde vem essa ideia longínqua de causação contra a qual argumentas." Esta questão é pertinente, mas espero tê-la respondido. Sentimos, após a conjunção constante,

60 Nos Diálogos, não há nenhum sinal desta prova. Pelo contrário, na História natural da religião aparece como explicação para a atribuição por parte dos humanos de inteligência às forças naturais: "Os homens têm uma tendência natural para conceber todos os seres segundo sua própria imagem [...]. Descobrimos formas de faces humanas na lua, e de membros nas nuvens, e por uma inclinação natural, se não for corrigida pela experiência ou pela reflexão, atribuímos maldade ou bondade a tudo o que nos faz mal ou nos agrada. [...] Não é surpreendente, então, que o homem, absolutamente ignorante das causas, e ao mesmo tempo tomado por tamanha ansiedade quanto ao seu futuro destino, reconheça imediatamente que depende de poderes invisíveis, dotados de sentimentos e inteligência." (III, §2)

61 Segundo o editor, esta é uma citação de Horácio (Epístolas, I, vi, 67-8). Ei-la completa: "Vive, vale! Si quid novistis rectius istis,/ Candidus imperti; si nil his utere mecum." Na tradução de António Luiz de Seabra: "Adeus, e sê feliz. - Se outra doutrina/ Melhor conheces, franco ma revela;/ Mas se não a sabes, desta te utiliza." In: HORÁCIO FLACO, Quinto. Satyras e Epístolas. Porto: Cruz Coutinho, 1846. 
uma transição fácil duma ideia para a outra, ou uma conexão na imaginação. E, como nos é usual transferir nossos próprios sentimentos para os objetos dos quais eles são dependentes, atrelamos o sentimento interno aos objetos externos. Se nenhum dos exemplos de causa e efeito parece ter qualquer conexão, mas apenas similares repetidos, achar-te-ás obrigado a ter recurso a esta teoria.

Lamento que nossa correspondência nos leve a estas especulações abstratas. Pensei, li e compus muito pouco sobre tais questões ultimamente. Ética, política e literatura empregam todo o meu tempo, mas ainda tenho de achar os outros tópicos mais curiosos, importantes e úteis do que qualquer geometria que seja mais profunda que Euclides. Se, para responder às dúvidas levantadas, novos princípios de filosofia têm que ser lançados, essas dúvidas não serão elas próprias muito úteis? Não serão preferíveis ao assentimento cego e ignorante? Espero poder responder às minhas próprias dúvidas: mas, e se eu não puder, o que há de admirar nisto? Para dar fôlego a mim mesmo e falar magnificente, acaso não poderei observar que Colombo não conquistou impérios nem implantou colônias?

Se não desembaracei o nó tão bem nesses últimos papéis que te enviei, como talvez o tenha feito no mais recente, asseguro-te que isto não procedeu de falta de boa-vontade. Mas alguns assuntos são mais fáceis do que outros; nalgumas vezes, é-se mais feliz nas pesquisas e investigações do que noutras. Ainda tenho recurso ao si quid novisti rectius. Não a fim de fazer-te um elogio, mas sim por uma dúvida ou curiosidade real filosófica.

Não faço elogios porque não os desejo. Por esta razão, agradame muito teres falado tão friamente da minha Petição. Não obstante, dei ordens para que ela fosse impressa, as quais talvez sejam executadas - embora eu creia que talvez tivesse feito melhor em abandoná-la. Não porque ela causará ofensa, mas porque não dará entretenimento; não porque ela pode ser chamada de 
profana, mas porque pode talvez merecidamente ser chamada de obtusa. Para falar a verdade, sempre fui tão indiferente à fortuna, - e, especialmente agora que estou mais avançado na vida, estou um pouco mais à minha vontade, adaptado à minha frugalidade, - que não temo nem espero nada de qualquer homem, e estou bem indiferente tanto à ofensa quanto ao favor. Eu não apenas não sacrificaria a verdade ou razão por opiniões políticas, como nem mesmo uma piada. Podes dizer-me que devo ter invertido a ordem destes pontos e pus a piada em primeiro lugar, já que é usual para as pessoas ser muitíssimo afeitas às suas performances nos assuntos nos quais elas no mínimo fizeram por exceler; e que, consequentemente, eu daria mais para ser tido por bom cômico do que para ser elogiado pela erudição, sutileza e invenção. A esta insinuação maliciosa não darei resposta, mas procederei com meu assunto.

Creio, no entanto, que não tenho mais nada a dizer sobre isso, mas sim a agradecer-te pelo Estrabão. Se o portador que te entregará isto não te encontrar em casa, mandarás, por favor, o livro para seu alojamento. Seu nome é Thomas Henderson, o portador de Berwick. Ele deixa a cidade às terças-feiras por volta do meio-dia e envia para James Henderson, Stables, entre Foot of Cant's Close e Blackfriars' Wynd.

Depois de teres terminado com esses papéis, por favor retorne-os pelo mesmo portador. Mas não há pressa. Ao contrário, quanto maior o tempo em que os retiveres, devo crer que estás pensando mais seriamente em executar o que desejo de ti. Sou, caro Senhor,

Teu o mais sinceramente,

David Hume.

Ninewells near Berwick.

10 de março de 1751 


\section{P.S.}

Se te persuadires a ajudar-me a defender Cleantes, imagino que não precisarás inteirar-te além da Parte 3 . Ele concede, de fato, na Parte 2, que toda a nossa inferência se funda na similitude entre os trabalhos da natureza e os efeitos usuais da mente. Do contrário, eles têm de parecer mero caos. A única dificuldade é por que outras dissimilaridades não enfraquecem o argumento. E, de fato, pela experiência ou sentimento, parece que elas não o enfraquecem tanto quanto poderíamos esperar. Uma teoria para resolver isto seria muito aceitável.

Espero que tenciones estar nesta região durante esta estação. Sinto muito por ouvir que a Sr. ${ }^{\text {a }}$ Murray esteve doente, mas espero que ela esteja melhor agora.

Não tenho o menor escrúpulo em pressionar-te para me escreveres algo regular sobre este assunto. Será um tipo de exercício para ti e melhorará teus estilo e invenção. 


\section{Carta ao AUTOR de The Delineation of the Nature and Obligation of Morality ${ }^{62}$}

(L, v. I, p. 172-4)

Senhor,

Quando te escrevo, não sei a quem me dirijo; sei somente que és alguém que me fez uma grande honra, e a cujas civilidades estou obrigado. Se formos estranhos, rogo para que possamos nos conhecer tão logo aches apropriado revelar-te; se já nos conhecemos, rogo para que possamos ser amigos; se amigos, rogo para que sejamos ainda mais amigos. A conexão entre nós, enquanto homens de letras, é maior do que nossa diferença ao aderirmos a diferentes seitas ou sistemas. Revivamos os tempos felizes quando Ático e Cássio, os epicuristas, Cícero, o acadêmico,

62 Diz o editor das cartas: "James Balfour of Pilrig (1705-95), um advogado. Indicado professor de Filosofia Moral em Edimburgo (1754), transferido para a cadeira de Lei da Natureza e das Nações (1764), autor de $A$ delineation of the nature and obligation of morality, with reflexions upon Mr. Hume's book entitled 'An essay concerning the principles of morals' (anon. 1753), Philosophical Essays (anon. 1768) e Philosophical Dissertations (subscrito, 1782). Somerville, que assistiu às suas aulas na Universidade, diz que suas conferências consistiam basicamente em ilustrações desconexas do De Jure Civis de Pufendorff, mas que ao final da sessão proferiu seis conferências, cuidadosamente preparadas, que 'pretendiam refutar as doutrinas contidas nalguns dos Ensaios do Sr. Hume, então universalmente lidos, em especial aqueles sobre poderes ativos, causa e efeito, liberdade e necessidade.' (My own Life and Times, 17)" 
e Brutus, o estoico, podiam, todos eles, viver juntos em amizade sem reservas, e eram indiferentes a todas essas distinções, exceto na medida em que elas forneciam um assunto agradável para discurso e conversa. Talvez sejas um jovem ${ }^{63}$ e, estando cheio dessas ideias sublimes que expressaste tão bem, penses que não possa haver virtude num sistema mais confinado. Não sou um velho, mas, sendo de bom temperamento, sempre achei que vistas mais simples fossem suficientes para me fazer agir numa maneira ra-

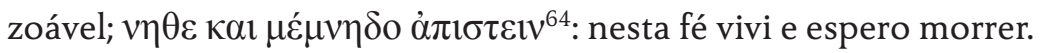

Tuas civilidades para comigo superam tanto tuas severidades que eu seria ingrato em notar algumas expressões que, no calor da composição, caíram de tua pena. Devo apenas queixar-me de ti um pouco por atribuir a mim opiniões que pus na boca do cético do Diálogo ${ }^{65}$. Seguramente tentei refutar o cético com toda a força que domino; e minha refutação deve ser reconhecida como sincera, porque extraída dos princípios capitais do meu sistema. Mas me imputas tanto as opiniões do cético quanto as opiniões do antagonista, o que jamais posso admitir. Em todo diálogo, não se pode supor mais do que uma pessoa a representar o autor.

Tua severidade num ponto, o da castidade, é tão grande e estou tão pouco cônscio de ter dado qualquer ocasião justa para ela, que ela me forneceu uma pista para formar uma conjectura, talvez mal fundada, concernente à tua pessoa. ${ }^{66}$

63 Hume nasceu em 1711 - seu destinatário era, portanto, seis anos mais velho.

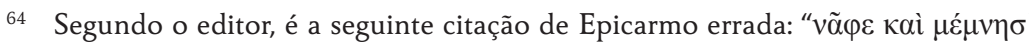
$\alpha \dot{\tau} \iota \sigma \tau \varepsilon \tau v^{\prime}$, i.e., "Sê ajuizado e lembra-te de não saber". Ainda segundo ele, há chances de os erros não serem de Hume, mas terem ocorrido numa transcrição da carta.

65 Trata-se do diálogo que vem anexo à Investigação sobre os princípios da moral.

66 Aqui o editor das cartas pergunta: "Será que Hume supôs honestamente que um parágrafo como o seguinte, tirado do Diálogo, não ofenderia um pudico? - 'É desnecessário dissimular: a consequência dum comércio bem livre entre os sexos e de eles viverem muito juntos terminará muito frequentemente em intrigas e galanteio. Devemos sacrificar algo de útil, se estivermos muito ansiosos para obter qualidades agradáveis, e não podemos pretender alcançar 
Espero roubar um pouco do lazer das minhas outras ocupações a fim de defender minha filosofia contra teus ataques. Se eu tiver alguma ocasião de dar uma nova edição ao trabalho, o qual honraste com uma resposta, devo fazer grande proveito de tuas notas, e espero obviar algumas de tuas críticas.

Teu estilo é elegante, e pleno de imagens agradáveis. Nalguns poucos lugares, não corresponde plenamente a minhas ideias de pureza e correção. Suponho que o meu fica ainda mais abaixo segundo tuas ideias. A este respeito, certamente podemos ser úteis um ao outro. Quanto aos nossos sistemas filosóficos, suponho que estejamos ambos tão fixos que não há esperanças de conversa entre nós; e, de minha parte, não duvido senão de que nós dois devemos fazer bem em ficar como estamos.

Sou, senhor, com grande estima,

Teu mais obrigado e humilde servo

David Hume.

Edimburgo, 15 de março.

1753.

igualmente todo tipo de vantagem. Exemplos de licenciosidade, multiplicandose diariamente, vão enfraquecer o escândalo entre um dos sexos, e ao outro vão ensinar gradativamente a adotar a máxima de La Fontaine sobre a infidelidade feminina: Se alguém sabe, é besteira; se ninguém sabe, não existe."” 


\section{Carta a AdAm Smith}

(NL, p. 51-5)

Lisle Street Leicester Fields, 12 de abril de 1759.

\section{Caro Smith,}

Agradeço a ti pelo agradável presente de tua Teoria [dos sentimentos morais]. Wedderburn e eu fizemos de presente nossas cópias para conhecidos nossos que temos por bons juízes, e adequados para espalhar a reputação do livro. Mandei uma para o Duque de Argyle, para Lorde Lyttleton, Horace Walpole, Soames Jennyns e Burke, um cavalheiro irlandês que escreveu ultimamente um belo tratado sobre o sublime. Millar desejou minha permissão para mandar uma em teu nome para o Dr. Warburton $^{67}$. Demorei a escrever-te até que eu pudesse contar-te algo do sucesso do teu livro e prognosticar com alguma probabilidade se ele há de se condenar irremediavelmente ao Oblívio ou se há de se registrar no Templo da Imortalidade ${ }^{68}$. Embora tenha sido pu-

67 Segundo os editores das New Letters, Raymond Klibansky e Ernerst Mossner, Warburton teve participação na censura que transformou as pretendidas Cinco Dissertações nas Quatro Dissertações, incluindo (1) "A História Natural da Religião", (2) "Das Paixões", (3) "Da Tragédia", (4) "Do padrão do gosto" e deixando de fora (5) os ensaios "Do Suicídio" e "Da Imortalidade da Alma".

68 Há um pano de fundo pagão aqui: Após a morte, as almas poderiam seguir para o Rio Lete, do esquecimento, ou então, caso fossem grandes mortais favoritos dos deuses, passavam a eternidade entre imortais nos Campos Elíseos. 
blicado há apenas umas poucas semanas, acho que já aparecem alguns sintomas fortes, de modo que quase posso aventurar-me a predizer seu destino. Em resumo, é o seguinte - - Mas fui interrompido em minha carta por uma visita tola impertinente de alguém que há pouco voltou da Escócia. Ele me diz que a Universidade de Glasgow pretende declarar vacante o cargo de Rouet, já que este foi para o estrangeiro com Lorde Hope. Só não pergunto se terás nosso amigo Ferguson à vista, caso outro projeto de conseguir-lhe uma vaga na Universidade de Edimburgo falhe. Ferguson poliu e melhorou muitíssimo seu Tratado sobre o refinamento ${ }^{69}$, e com algumas correções dará um livro admirável, e desvelará um gênio elegante e singular. A Epigoníada, espero eu, bastará, mas é uma obra algo árdua. Como tenho certeza de que consultas às vezes as resenhas, verás na resenha crítica uma carta sobre esse poema, e desejo que empregues tuas conjecturas em descobrir o autor. Deixa-me ver uma amostra de tua habilidade em conhecer penas adivinhando tu quem é a pessoa ${ }^{70}$. Tenho medo dos Law Tracts de Lorde Kames. Pode-se pensar tão bem em fazer um bom molho da mistura de losna e babosa quanto uma composição agradável juntando metafísica e Direito escocês. Contudo o livro, creio eu, tem mérito - embora poucos venham a se esforçar para mergulhar nele. Mas, para voltar ao teu livro e seu sucesso na cidade, devo dizer-te - - Uma praga de interrupções! Ordenei que ninguém entrasse, mas ainda assim está aqui alguém que me invadiu de novo. É um homem de letras, e tivemos um bocado de conversa literária. Contaste-me que estavas curioso a respeito de anedotas literárias e, portanto hei de informar-te dumas poucas que vieram ao meu conhecimento. Acredito que mencionei para ti o livro de Helvétius, De

\footnotetext{
69 Pedro Paulo Pimenta elenca especulações de que texto seja este; dentre elas, a de ser um esboço do Ensaio de história da sociedade civil. (Cf. PIMENTA, P. P. G., "Entre refinamento e civilização", in Dois Pontos, v. 8, n. 11, 2011.)

70 Tratava-se do próprio Hume.
} 
l'Esprit. É digno de tua leitura não por sua filosofia, à qual não dou valor tão alto, mas por sua composição agradável. Recebi uma carta dele há poucos dias, na qual me conta que meu nome era muito mais frequente no manuscrito, mas que o censor de livros em Paris o obrigou a retirar. Voltaire publicou recentemente uma pequena obra chamada Candide, ou l'Optimisme. É cheia de animação e impiedade, e é de fato uma sátira da providência sob pretexto de criticar o sistema leibniziano ${ }^{71}$. Devo te dar um pequeno detalhe dela - - "Mas o que tudo isto tem a ver com meu livro?", dizes - - Meu caro Smith, tem paciência: Acalmate em tranquilidade: Mostra-te um filósofo na prática tão bem quanto na profissão: Pensa no vazio, e precipitação, e futilidade dos juízos comuns dos homens: $\mathrm{O}$ quão pouco regulados pela razão em qualquer assunto, ainda mais em assuntos filosóficos, que excedem tanto a compreensão do vulgo. Non si quid improba Roma, Elevet, accedas examenque improbum in illa, Perpendas trutina, nec te qucesiveris extra ${ }^{72}$. O reino dum homem sábio é seu próprio peito; ou, se ele for olhar mais longe, será apenas pelo juízo duns poucos seletos, que são livres de preconceitos e capazes de examinar seu trabalho. Nada de fato pode ser uma presunção maior de falsidade do que a aprovação pela multidão, e Focião,

71 Esta é uma interpretação difícil de dar da posição de Voltaire. Embora anticlerical, ele era um teísta, e ao longo do Dicionário Filosófico afirma a providência (cf. o verbete "Teísta"), além de adotar posições bem distintas da de Hume, como a de que é preciso crer em Deus para ser bom (cf. "Ateu, ateísmo"). Também por ser teísta, estava muito preocupado em sustentar uma espécie de metafísica newtoniana (tendo chegado a escrever La Métaphysique de Newton) e, por conseguinte, atacar Leibniz.

72 Hume citava de memória, e a versão correta é esta: "Non, si quid turbida Roma/ Elevet, accedas; examenve improbum in illa/ Castiges trutina; nec te quæsiveris extra" (Persius, Sat., I. 5-7), que significa "Se Roma, turva, ninguém desacredita, não adiras; não te dês o pensamento de corrigir o torto juízo da lei; não o procures fora de ti mesmo". (Baseei-me na tradução de Amadio Ronchini, cuja referência é: PERSIO FLACO, Aulo. Le Satire. Parma: Michele Adorni, 1889.) 
sabe-lo, sempre suspeitou de ter cometido alguma asneira quando era aplaudido pelo populacho.

Supondo, portanto, que te preparaste devidamente para o pior por todas essas reflexões, prossigo para contar-te as melancólicas novas de que teu livro foi bem desafortunado: pois o público parece disposto a aplaudi-lo ao extremo. Ele foi procurado pela gente tola com alguma impaciência, e a turba de literati está começando a elogiar muito alto. Três bispos visitaram ontem a loja de Millar a fim de comprar cópias e fazer perguntas sobre o autor: o bispo de Peterborough disse que passou a noite com uma companhia da qual o ouviu exaltado sobre todos os livros do mundo. Podes concluir qual opinião verdadeiros filósofos entreterão do livro, quando advogados da superstição o elogiam tão altamente. O Duque de Argyle é mais decisivo a seu favor do que o costume: suponho que ele ou considera o livro exótico ${ }^{73}$, ou acha que seu autor lhe será útil nas eleições de Glasgow. Lorde Lyttleton diz que Robertson, Smith e Bower são as glórias da literatura inglesa. Oswald alega não saber se colheu dele mais instrução ou entretenimento - mas podes julgar com facilidade qual confiança se deve depositar sobre esse juízo, de quem esteve envolvido por toda a vida em negócios públicos e nunca vê defeitos nos amigos. Millar exulta e se gaba de que dois terços da edição já foram vendidos, e que está agora seguro do sucesso. Vês que filho da terra é este, para avaliar livros só pelo lucro que lhe trazem. Deste ponto de vista, creio que o teu deve provar ser um livro muito bom.

Charles Townshend, que se passa pelo camarada mais esperto da Inglaterra, está tão tomado pelo desempenho que disse a Oswald que colocaria o Duque de Buccleugh sob o cuidado do autor, e tentaria tornar para ele proveitoso aceitar o cargo.

73 Talvez este seja aqui um sinônimo de exotérico, i.e., "passível de ser ministrado a um grande público, e não somente a um grupo seleto de alunos", segundo o Houaiss. 
Tão logo ouvi isto, chamei-o duas vezes tendo em vistas em falar consigo sobre o assunto e convencê-lo da adequação de mandar um jovem nobre para Glasgow, pois não pude esperar que ele te oferecesse quaisquer condições que te tentassem a renunciar à tua carreira de professor. Mas não consegui falar com ele. O Sr. Townshend é tido por um pouco incerto em suas decisões, então talvez não precises se basear muito nesse ímpeto.

Em recompensa por tantas coisas mortificantes, que nada senão a verdade poderia ter arrancado de mim e que eu poderia facilmente ter multiplicado para um número maior, não tenho dúvidas de que sejas um cristão tão bom para devolver bem pelo mal e lisonjear minha vaidade contando-me que todos os devotos da Escócia me insultam por causa da minha descrição de John Knox e a Reforma etc. Suponho que estejas feliz por ver meu papel acabar e que estou obrigado a concluir com

Teu humilde servo,

David Hume 


\section{Carta a Gilbert Elliot de Minto} (NL, p.69-71)

Caro senhor,

Nessa nova edição ${ }^{74}$ corrigi vários erros e negligências que procederam principalmente dos pestilentos preconceitos do whiggismo $^{75}$, com o qual eu estava infectado demais quando comecei o trabalho. Corrigi alguns desses erros numa edição anterior, mas, tendo resolvido acrescentar a esta as citações e autoridades para os reinados de Jaime I e Carlos I, fui obrigado a examinar outra vez os autores mais consideráveis que trataram desses reinados e, felizmente, descobri mais alguns erros, que corrigi agora. Comecei a História com esses dois reinados e agora descubro que eles, mais do que todos os outros, foram corrompidos pelo rancor whig, que realmente mereci o nome de "escritor de partido" e que me gabei de minha imparcialidade sem qualquer fundamento. Mas se agora me concederes a honra de fazer do meu trabalho um segundo exame, estou persuadido de que não mais me atirarás este epíteto reprovável e me absolverás de toda a

\footnotetext{
74 Da História da Inglaterra.

75 O partido Whig era o liberal de então, e se contrapunha ao conservador Tory.
} 
propensão ao whiggismo. Se continuares a me repreender, ficarei obrigado a retaliar-te e a proclamar: Whig vous-même.

Na página 33, vol. 5, encontrarás uma justificação para as imposições estabelecidas por Jaime I, sem autoridade do Parlamento; nas p.113, 114, 389, uma justificação para perseguir os puritanos, na p. 180, uma justificação para Carlos I arrecadar arqueação e poundage com consentimento do parlamento. Na p. 100 absolvo Jaime I da prevaricação da qual eu o tinha acusado antes precipitadamente. Este último erro de fato era inocente, e posso explicá-lo com facilidade: li a narrativa de Buckingham em Rushwort e Franklin, os dois arrecadadores opositores. Vi o que achei ser o mesmo papel na história parlamentar, mas não reparei numa linha ao fim, na qual se diz que o papel foi tirado do arquivo mais completo do que aquela coleção. Quando li isso depois, encontrei o artigo citado aqui. Então essa asneira não procedeu de nenhum espírito de whiggice.

Agora justifico Jaime II mais explicitamente em seu exercício de dispensa de poder, que entrelaçou intimamente constituição e monarquia - cf. vol. 6, p. 393, 394, 395, 400. No Volume 4, p. 322, 323, menciono uma obra de tirania bem notável, ou do exercício de poder arbitrário praticado naquele período, e que vieram ao meu conhecimento desde a publicação desse volume.

Há muitos outros melhoramentos e alterações através do conjunto, e estou contente por o próprio Millar ter feito a ti uma oferta dessa edição. Sem bajular-te, tenho de dizer que não há ninguém que eu queira tanto que veja meus escritos tão corretos quanto eu possa torná-los, e eu estava pensando em pedir ao $\mathrm{Sr}$. Millar para te fazer essa oferta.

Mas não existe fim de correção. Nessa nova edição, vol. v, p. 205, inseri uma historieta bem curiosa de Sir George Markham, que peguei de Lorde Lansdowne, o qual considerei uma autoridade a salvo da historiagem whig. Mas desde então me foram mostrados os Reports de Hobart, que é infinitamente mais au- 
têntico do que Lorde Lansdowne, e a historieta é contada lá de modo a justificar inteiramente o rei e a Câmara Estrelada - então podes ainda me repreender dizendo que o pendor infame não foi inteiramente purgado.

Não estou ocupado com nenhum trabalho agora; mas, se eu me cansar da ociosidade - ou, falando mais propriamente, da leitura como diversão -, posso continuar minha História. Meu único desencorajamento é que não posso pretender terminar esse trabalho no meu gabinete, mas tenho que solicitar ao governo documentos e serviços de informação, coisa que abomino mortalmente.

Não é duro e tirânico de tua parte, mais tirânico do que qualquer ato dos Stuarts, não me permitir publicar os meus Diálogos? Ora, por favor, não pensas que uma dedicatória apropriada pode apaziguar o que for excepcional neles? Estou aderindo muito à mentalidade do meu amigo Corbyn Morrice, que diz que escreve todos os seus livros por causa das dedicatórias.

Estou muito contente por ouvir de Lorde Minto que pretendes passar uma grande parte do próximo verão nesta região. Embora te tenhas tornado agora um grande homem, estou certo de que devo ter muita satisfação com tua sociedade e conversas quer dizer, se eu não for empurrado para fora pelos peticionários que te pressionarão.

Entrementes sou, caro senhor,

Teu afetuoso amigo e servo

David Hume.

Edimburgo,

12 de março de 1763. 


\section{Carta a Adam Smith ${ }^{76}$}

(L, v. II, p. 316-7)

Londres, 3 de maio de $1776^{77}$

Meu caro amigo,

Mando-te inclusa uma carta ${ }^{78}$ ostensível, conforme ao teu desejo. Penso, no entanto, que teus escrúpulos são infundados. Mallet foi dalguma forma prejudicado por publicar Lorde Bolingbroke? Ele recebeu em seguida um ofício do rei de então e de Lorde Bute, o homem mais santarrão do mundo, e sempre se justificou através de sua consideração sagrada pelas últimas vontades dum amigo morto. Ao mesmo tempo, admito, teus escrúpulos têm uma aparência especiosa. Mas minha opinião é que se, à minha morte, te determinares a nunca publicar estes papéis, deves deixá-los selados com meu irmão e família, com alguma inscrição em que reserves a ti próprio o poder de reclamá-los tão logo aches apropriado. Se eu viver mais alguns poucos anos, devo publicá-los eu mesmo. Considero uma observação de Ro-

\footnotetext{
76 Esta carta chegou atrasada porque Hume escolhera mandá-la pelo portador, ao invés de pelo correio, como veremos adiante.

77 Hume estava morrendo, com um câncer então incurável no sistema digestivo.

78 Trata-se da carta seguinte.
} 
chefoulcault [sic] segundo a qual o vento, embora extinga a vela, inflama o fogo.

Podes ficar surpreso em me ouvir falar de viver anos, considerando o estado em que me viste e a opinião que tanto eu quanto todos os meus amigos em Edimburgo têm a este respeito. Mas embora eu não possa visitar o temperamento alegre de nosso amigo John, me encontro muito recuperado em trânsito, e espero que as águas de Bath e outras viagens possam acarretar minha cura.

Pela pouca companhia que tenho visto, acho que a cidade está bem cheia de seu livro ${ }^{79}$, que recebe aprovação geral. Muitas pessoas acham disputáveis alguns pontos particulares, mas isto certamente esperavas; estou feliz em ser um desta gente, já que esses pontos serão o assunto de futura conversa entre nós.

Saio para Bath, creio que na segunda-feira, por direções de Sir John Pringle, que diz não ver nada a temer no meu caso. Se me escreveres, hem!, hem!, digo, se me escreveres, manda tuas cartas num envelope para o Sr. Strahan ${ }^{80}$, que terá meu endereço.

Lamento muito, ao sair de Edimburgo, que eu perca muito de tua companhia, da qual eu teria desfrutado neste verão.

Sou, caro Smith,

Teu, sincera e afetuosamente,

David Hume.

Para Adam Smith Esqr em Kirkaldy.

\footnotetext{
79 Agora, trata-se d'A Riqueza das Nações.

80 William Strahan era o editor de Hume; John Pringle, um amigo médico.
} 


\section{Carta a Adam Smith}

(L, v. II, p. 317-8)

Londres, 3 de maio de 1776

Meu caro senhor,

Depois de ter refletido com mais maturidade sobre aquele artigo do meu testamento pelo qual deixo-te o uso de todos os meus papeis, com o pedido de que publiques meus Diálogos sobre a religião natural, dei-me conta de que tanto por causa da natureza do trabalho quanto de tua situação, pode ser impróprio apressar a publicação. Portanto, tomo a presente oportunidade para qualificar esse pedido amigável: contento-me em deixar inteiramente à tua discrição em que momento publicarás aquela obra ou se de fato a publicarás mesmo. Encontrarás entre meus papéis uma obra bem inofensiva, chamada Minha vida, que compus poucos dias antes de deixar Edimburgo, quando pensei, como todos os meus amigos, que minha vida não tinha esperanças. Não pode haver objeções a que essa pequena obra seja mandada à Sra. Strahan, Cadell e aos proprietários de meus outros trabalhos para ser afixada em qualquer edição futura. Sou, caro senhor,

Teu amigo e servo mais afeiçoado

David Hume

Dr. Adam Smith 


\section{Carta a William Strahan}

(L, v. II, p. 322-4)

Bath, 8 de junho de 1776.

Meu caro senhor,

Lastimarás ao ouvir que preciso retirar todas as minhas boas descrições que eu te dera de meu estado de saúde. As águas, depois de parecerem se harmonizar comigo, têm sensivelmente um efeito mau, e abandonei completamente o seu uso. Espero apenas pelas direções de Sir John Pringle para deixar este lugar e devo, creio, viajar até o norte em poucos dias. Se alguma carta para mim chegou endereçada a ti, faz a gentileza de retê-las até que eu possa te informar minha rota.

Fico feliz em descobrir que foste capaz de começar essa edição nova com tanto zelo. Fi-la extremamente correta; ao menos acho que, se eu fosse viver mais vinte anos, jamais conseguiria dar-lhe mais algum melhoramento. Isto é alguma pequena satisfação para mim na minha situação presente, e posso acrescentar que é quase a única que meus escritos já me ofereceram - pois quaisquer retornos convenientes de aprovação proveniente do público pelo cuidado, precisão, trabalho, desinteresse e coragem de minhas composições ainda estão por vir. Embora, confesso a ti, eu veja muitos sintomas de que eles estão por vir. Mas acon- 
tecerá comigo como com muitos outros escritores: embora eu tenha alcançado uma idade considerável, não hei de viver para ver alguma justiça feita a mim. Não é improvável, no entanto, que minha autoestima e boas impressões me conduzam a este modo de pensar.

Tão logo esta edição seja terminada, por favor manda uma cópia de todos os dez volumes ${ }^{81}$ para Sir John Pringle, o mesmo para o Sr. Gibbon, uma cópia da História para a senhora Elliot na rua Brewer, seis cópias do todo para mim em Edimburgo, ou para meu irmão no caso de minha morte.

Se este evento acontecer, como é provável, antes da publicação desta edição, há um pedido que quero fazer-te: antes de deixar Edimburgo, escrevi uma pequena obra (podes acreditar que é uma bem pequena) que chamo de "A História de minha própria vida". Desejo que ela seja afixada nesta edição - isto será tido por curioso e divertido. Meu irmão ou o Dr. Adam Smith a mandarão para ti, e lhes darei instruções para este propósito.

Devo também falar-te dum outro trabalho mais importante. Há alguns anos compus uma obra que podes fazer num pequeno volume de duodécimo ${ }^{82}$. Chamo-a de Diálogos sobre a religião natural. Alguns dos meus amigos me lisonjeiam dizendo que esta é a melhor coisa que jamais escrevi. Até agora me abstive de publicá-la porque ultimamente estive desejoso por viver quieto

81 Segundo o editor das Cartas, Greig, eram oito volumes da História da Inglaterra e dois dos Ensaios. Ou seja, tratava-se quase das obras completas, pois todos os escritos filosóficos, à exceção do Tratado da natureza humana (que Hume substituiu pelas duas Investigações e a Dissertação sobre as paixões) dos Diálogos e dos ensaios "Sobre a Imortalidade da Alma" e "Do suicídio", saíram em dois volumes com o título Ensaios e tratados sobre vários assuntos.

Os volumes da época eram, em geral, quarto, oitavo e duodécimo - o nome derivava da fração da folha que uma página ocupava. Os mais comuns eram o oitavo, do tamanho padrão de um livro de hoje. Contudo, o fato de existirem edições em quarto conferia a uma obra algum prestígio. Duodécimo, ao contrário, era o tipo de edição mais barato. Cf. SHER. The Enlightenment \& The Book. Chicago: Chicago University Press, 2006. 
e me manter longe de todo clamor - pois, embora ela não seja mais ofensiva do que algumas coisas que já publiquei, ainda assim, sabes que algumas delas foram tidas por muito ofensivas e, sendo prudente, eu deveria tê-las suprimido. Lá introduzo um cético, que é de fato refutado e por fim desiste da argumentação - mais ainda, confessa que estava apenas se divertindo com cavilações -, mas, antes de ser silenciado, apresenta vários tópicos que gerarão ressentimento e serão tidos por audaciosos e livres demais, bem como muito distantes da via comum. Tão logo eu chegue a Edimburgo, pretendo imprimir uma pequena edição de 500, da qual posso dar uns 100 de presente e devo fazer do restante um presente para ti, junto com a propriedade literária do todo, desde que não tenhas nenhum escrúpulo, em tua situação presente, de ser o editor. Não é necessário que afixes teu nome na página com o título. Declaro seriamente que, depois que o Sr. Millar, tu e o Sr. Cadell reconhecestes vossa publicação da Investigação sobre o entendimento humano, não sei de nenhuma razão por que devesses ter o mínimo escrúpulo com relação a esses diálogos. Eles serão muito menos detestáveis para a lei, e não mais expostos ao clamor popular. Qualquer que seja a tua resolução, rogo para que mantenhas um completo silêncio sobre este assunto. Se eu tos deixar no meu testamento, executar o desejo dum amigo morto tornará a publicação ainda mais desculpável. Mallet nunca sofreu nada por ser o editor dos trabalhos de Bolingbroke.

Há duas correspondências atrás, mandei-te uma cópia do pequeno ensaio que mencionei.

Sou, caro senhor, com grande cuidado e sinceridade,

Teu mais humilde e obediente servo

David Hume 


\section{Carta a Adam Smith}

(L, v. II, p. 334)

Edimburgo, 15 de agosto de 1776

Meu caro Smith,

Encomendei uma nova cópia dos meus Diálogos para ser feita além daquela que será mandada ao Sr. Strahan, e que ficará com o meu sobrinho. Se mo permitires, encomendarei uma terceira cópia para ser confiada a ti. Isto não te obrigará a nada, mas servirá como segurança. Ao revisá-los (o que não fiz nesses últimos 15 anos), acho que nada pode ser escrito mais cuidadosa e astuciosamente. Certamente os esqueceras. Permitir-me-ás deixar-te a propriedade da cópia, no caso de eles não terem sido publicados cinco anos depois do meu falecimento? Tem a gentileza de me escrever uma resposta em breve. Meu estado de saúde não me permite esperá-la por meses.

Teu afetuosamente,

David Hume

Para Adam Smith Esqr at Kirkaldy 


\section{Carta a Adam Smith}

(L, v. II, p. 335-6.)

Edimburgo, 23 de agosto de $1776^{83}$

Meu caríssimo amigo,

Estou obrigado a fazer uso da mão do meu sobrinho ao escrever-te, já que não levanto hoje.

Não há homem em quem eu tenha mais confiança do que o Sr. Strahan, mas ainda assim deixei a propriedade daquele manuscrito para o meu sobrinho David, no caso de, por algum acidente, ele não ser publicado dentro de três anos após meu falecimento. O único acidente que pude prever seria um com a vida do Sr. Strahan, e sem essa cláusula meu sobrinho não teria nenhum direito de publicá-lo. Faz a gentileza de avisar ao Sr. Strahan esta circunstância.

És gentil demais em pensar que algumas bagatelas que me preocupam são tão dignas de tua atenção, mas dou-te toda a liberdade para fazer qualquer acréscimo que te aprouver na descrição de minha vida.

Vou muito rápido para o declínio, e na noite passada tive uma pequena febre da qual esperei que abreviasse essa doença te-

83 Hume morreu no dia 25 de agosto de 1776, aos sessenta e cinco anos, e esta é sua última carta. 
diosa, mas infelizmente em grade medida passou. Não posso te propor que venhas cá por minha própria conta, já que me é possível ver-te numa parte tão pequena do dia, mas o Dr. Black pode informar melhor sobre o grau de força que pode de tempos em tempos remanescer comigo.

Adieu, meu caríssimo amigo.

\section{David Hume}

P.S. Foi uma asneira estranha mandar-te uma carta pelo portador.

Adam Smith Esqr. Kirkaldy 


\section{Posfácio $^{84}$}

O leão tem a cabeça muito grande que é pra não poder fugir da jaula.

(Millôr Fernandes)

É-nos hoje surpreendente o final dos Diálogos sobre a religião natural: Como será possível que Filão, triunfal desde o início, súbito resolva desdizer-se e aceitar a tese de Cleantes, tantas vezes rechaçada de tão variadas formas? Ademais, os argumentos de Filão são excessivamente convincentes, tornando difícil ao leitor aceitar o recuo do cético. Então, é inevitável que se pergunte: Como Hume, dispondo de meios mais do que suficientes para estropiar a tese de Cleantes, pôde fazer de tal personagem a vencedora dos Diálogos? Qual seria, enfim, a real opinião de Hume?

Aos leitores de séculos mais jovens, não é inexato dizer que Hume nos legou uma charada em forma de livro. Às charadas não é conveniente que respondamos de antemão, estragando a surpresa, mas decerto conviria uma seção de respostas ao final e esta é a razão de ser deste posfácio.

84 Esta é uma versão curta sem revisão bibliográfica de minha dissertação de mestrado, defendida em agosto de 2013 na Faculdade de Filosofia e Ciências Humanas da Universidade Federal da Bahia, tendo como banca os professores João Carlos Salles (orientador), João Paulo Monteiro e Rafael Azize. 
os Diálogos são a única obra de Hume voltada à discussão exaustiva dos fundamentos da crença em religiões, mas também a obra onde o autor jamais fala em seu próprio nome. Nossa intenção de determinar qual seja sua real opinião se torna bem exequível pelo fato de o tema religião ter mais de um livro seu e ser abordado por outro viés.

O outro livro de Hume voltado em específico para o tema é a História Natural da Religião. Lá, sabemos que na investigação que trate de religião "há duas questões, em particular, que chamam a nossa atenção, a saber: a que se refere ao seu fundamento na razão e a que se refere à sua origem na natureza humana." (Int.) São bem diferentes ambas as questões; afinal, seria possível, por exemplo, afirmar nula a resposta da primeira e prosseguir à explicação de como surgem certas crenças infundadas. Ademais, a questão não poderá ser reduzida a uma investigação geral da natureza humana por a crença em divindades não ser uniforme como a crença de que o fogo queima (Cf. NHR, Int.). Assim, investigação da História Natural da Religião visa a uma explicação apenas genética da crença religiosa: não concerne à validade dos raciocínios que conduzem a ela. A outra questão é o objeto dos Diálogos sobre a religião natural.

Para estranheza do leitor, a justificativa para que essa pergunta pelo fundamento racional passe em branco na História Natural da Religião é que ela tem resposta facílima e inevitável: “Todo o plano da natureza evidencia um autor inteligente, e nenhum investigador racional pode, após uma séria reflexão, suspender por um instante sua crença em relação aos primeiros princípios do puro teísmo e da pura religião" (ibidem). Ora, por esta afirmação temos que Cleantes está nada menos que óbvia e forçosamente certo. Se uma contemplação da paisagem perfeita que nos rodeia basta para calar o opositor, não faz sentido o filósofo escrever uma obra sequer para estabelecer a tese - e muito menos para 
contestá-la, porquanto incontestável. Pela Introdução da História Natural da Religião, temos que a redação dos Diálogos seria completamente supérflua.

Não podemos, porém, dizer que Hume mudou de ideia, tendo talvez achado que era uma questão óbvia mas depois atinado que não, ou então ruminado uma questão que descobriria depois ser facílima: Os Diálogos foram escritos antes da História Natural, e tiveram revisões crebras depois da publicação da História Natural. Assim, claro está que Hume não pode assentir a tudo o que ele próprio escreve (o que parecerá extravagância apenas se desconsideradas circunstâncias históricas). Será que ele acreditava que a discussão dos fundamentos da crença numa divindade era supérflua ou não?

Felizmente, os Diálogos tampouco são o único texto em que Hume trabalha a religião no âmbito epistemológico. Podemos apontar este tema tanto espalhado por ensaios, tais como os não publicados "Do suicídio" e "Da imortalidade da alma", quanto pelas obras menos específicas, a saber, o Tratado da natureza humana (que mesmo com cortes de seções dedicadas a temas religiosos rendeu a Hume a pecha de infiel da qual nunca se desvencilhara) e a Investigação sobre o entendimento humano, que em grande medida reformula o Livro I do Tratado, mas com o acréscimo das seções "Dos Milagres" e "De uma providência particular e de um estado futuro". É de notar, especialmente nos ensaios não publicados, a ferocidade do ataque humeano às crenças religiosas, ou ainda o modo passível de ser considerado irônico como Hume fala do fiel: um exemplo é que crer em milagres, para ele, é tão contrário à razão que haver quem creia pode ser considerado um verdadeiro milagre (cf. EHU, X, §41). Mas, se sua posição epistemológica for ferrenhamente contrária a qualquer religião, que razão afinal poderemos dar para que tenha posto em sua obra trechos que assintam à evidência empírica da existência divina, ainda mais sendo esta evidência mantida 
pelos teístas cristãos que visavam a dar fundamento filosófico às suas crenças?

A resposta é a mais simples: censura. A religião, quer no âmbito da epistemologia, quer no da moralidade, foi um assunto perseguido por Hume desde o início de sua juventude ${ }^{85}$, e a preocupação de que suas posições não resultassem em represálias se faz notar pela sua correspondência e pelas suas alterações das obras. Podemos apontar como exemplo disso a "castração" do Tratado da Natureza Humana, que acarretou a retirada duma seção sobre os milagres. Temos esta fala de Hume ao seu amigo para explicá-la:

Quanto ao Dr. Butler minha opinião concorda com a tua, e gostaria muito de lhe ser apresentado. Estou atualmente castrando a minha obra, isto é, cortando suas partes nobres, isto é, esforçando-me para que ela cause a menor ofensa possível; antes disso, não posso pretender colocá-la nas mãos de Butler. (NL, p. 2-3) $)^{86}$

Depois de ter sido lida por poucos amigos de confiança, o destino da versão sem mutilações foi as chamas; não obstante, dizia Hume, "quanto à força da argumentação, julgá-la-ás tal como está" 87 . Portanto, o motivo para alterar a obra não fora filosófico, mas sim uma receosa autocensura; e como epígrafe, o Tratado terminou por trazer a queixosa "Rara temporum felicitas, ubi sentire, quæ velis; et quæ sentia, dicere licet." ${ }^{88}$ Cabe também notar que temos no Dr. Butler um exemplo de leitor com quem Hume se preocupe em não ofender: um filósofo do clero (a saber,

85 Cf. a Carta II deste volume.

86 Servimo-nos da tradução de João Paulo Monteiro em seu Hume e a Epistemologia, p. 159.

87 Apud MONTEIRO, op. cit., p. 158.

88 "É rara a felicidade dos tempos em que se possa pensar o que bem se entenda, e o que se pense se possa dizer." (Tradução nossa.) 
um bispo) e defensor da evidência empírica da existência divina (i.e., um teísta experimental).

Ante a factual preocupação castradora de não causar ofensa, é preciso pôr em questão se Hume assente mesmo a tudo o que diz assentir em matéria de religião; noutras palavras, como pelo menos uma vez Hume alterou as partes que dizem respeito a religião no seu texto filosófico por motivo não-filosófico, devemos questionar se ele não o fizera noutros momentos. E o que atiça ainda mais esta dúvida é ele, tendo escrito ao mesmo tempo a História natural da religião e os Diálogos sobre a religião natural, dizer na primeira que toda a discussão da segunda tem resposta óbvia, resolvida com a mais ingênua e simples contemplação da natureza.

Além de colocar esta dúvida, podemos tentar, pressupondo-se a simples coerência da obra de Hume, apontar qual tenha de ser exatamente a posição do autor acerca do debate contido nos $\mathrm{Di}$ álogos. Para fazê-lo, é claro, o recurso mais imediato é este texto, e confrontaremos os argumentos das personagens a fim de apontar quais sejam os consistentes. No entanto, por Hume não falar aí em sua própria pessoa, um bom tira-teima será a Investigação sobre o entendimento humano, onde ele põe seus princípios e discute, à luz da teoria que estabelecera, questões que aparecem também nos Diálogos sobre a religião natural.

\section{O CENÁRIO INTELECTUAL EM QUE SURGEM OS DIÁLOGOS}

Se não hesitássemos em seguir Pânfilo, o discípulo de Cleantes que mistura narrativa com opinião, o resultado da discussão seria claro: os princípios mais próximos à verdade são os do seu mestre. Concordar com a conclusão do narrador e dá-lo por porta-voz do autor implica crer que Hume defenda o teísmo experimental, que deveria ser abraçado por qualquer ser racional que, contemplando o mundo, se dedicasse a pensar sobre a existência divina - afinal, a perfeição e o bom ordenamento que ele 
encontra o arrebatariam e lhe dariam a certeza de que tais são obra dum ser inteligentíssimo e poderosíssimo. Eis então a tese teísta: a evidente perfeição do mundo prova um autor inteligente. Uma vez que tal tese é nada menos que natural e fundada em sentimento arrebatador, sua negação só se explicaria pela teimosia dos ímpios ou dos metafísicos e só encontraria justificativa por meio de raciocínios abstrusos que, apenas eles, conseguiriam confundir a mente e, ofuscando a evidência do desígnio, desviá -la daquilo a que está por natureza inclinada.

Conquanto evidentemente despida de argumentação sofisticada e, mais do que isso, contrária a ela devido a sua pretensão de naturalidade, ao teísmo experimental não faltavam adeptos à época de Hume: entusiasmados com o sucesso da física newtoniana, intelectuais britânicos viam nesta mais uma evidência do desígnio dum criador inteligentíssimo. Entre eles havia o já mencionado Dr. Butler, autor d'A analogia da religião - obra que visa a expor e fundamentar a religião natural. Mas decerto há de ser tarefa espinhosa conferir legitimidade filosófica a argumentos que devem apelar à simples obviedade das sensações, fugindo de raciocínios abstrusos. O meio que Butler encontrou para executá -la foi o de afirmar ser inevitável o tipo de raciocínio sobre o qual se funda a religião natural; assim, já que é necessário para toda a vida comum, deve ser no mínimo lícito (se não forçoso) usá-lo em assuntos religiosos e filosóficos.

Butler começa por distinguir o que é relativo à matemática do que é relativo a questões de fato a partir do grau de assentimento que lhes podemos dar. Por certo, aponta ele, não podemos ter uma leve suspeita ou uma forte crença de que triângulos tenham três lados, ou de que dois mais dois seja igual a cinco; ao contrário, só podemos ou afirmá-los ou negá-los. Diferentemente, podemos também duvidar, suspeitar ou crer com toda a força que César tenha sido assassinado por Brutus, que ursos existam e que sereias cantem para atrair marinheiros. Trata-se, portanto, 
de dois tipos diferentes de evidência: um, chamado "evidência provável", é o que comporta diversos graus de assentimento; e o outro, chamado "evidência demonstrativa", é o que não comporta.

Tais graus vão da mais baixa presunção à mais elevada certeza moral, consistindo esta no "fundamento para uma expectativa sem qualquer dúvida" ${ }^{19} \mathrm{e}$, à medida em que os fatos enunciados pelas proposições vão se repetindo, elas vão aumentando em seu grau de assentimento. Assim, por mais que não possamos demonstrá-lo, jamais podemos perguntar a sério "se o sol nascerá amanhã e será visto onde sempre o fora, na figura de um círculo e não na de um quadrado" ${ }^{\prime 90}$ : esta é uma certeza moral, o grau mais elevado de assentimento que se dá a uma evidência provável.

Não se pode, pois, demonstrar que o sol nascerá amanhã, embora a isto assintamos com toda a força. Se perguntarmos a Butler por que assentimos ou por que temos qualquer evidência do tipo provável, sua resposta será que o fazemos por meio de um raciocínio, o analógico. A explicação, para ele, se expressa mesmo numa palavra:

Aquilo que de modo principal constitui a probabilidade se expressa pela palavra verossímil, i. e., semelhante a alguma verdade ou evento verdadeiro [...]. Afinal, quando determinamos que uma coisa é provavelmente verdadeira ou supomos que um evento aconteceu ou acontecerá, é por a mente ter notado nisto uma semelhança com outro evento que observamos ter acontecido. ${ }^{91}$

Assim, se sabemos pela experiência que o sol nasceu em todos os dias e sempre redondo, ao nos depararmos com uma situação semelhante às que foram seguidas pelo nascimento do sol redondo,

\footnotetext{
89 “A analogia da religião (Introdução)", p. 24.

90 Op. cit., p. 25.

91 Op. cit., p. 23.
} 
faremos uma analogia entre elas e a presente para concluir com a mais plena certeza moral que o mesmo se dará novamente. Isto é o que ele chama de "raciocínio por analogia"92.

A conclusão não poderia ser outra: "para nós, probabilidade é o verdadeiro guia da vida"93, um guia do qual não podemos escapar. Mas, mais do que isso, um guia do qual não devemos escapar, já que, no calor do sucesso da física newtoniana sobre a cartesiana, as demonstrações metafísicas e ontológicas estavam, por assim dizer, fora de moda. Para Butler, como para o grande público do seu tempo, é claro que quem pretender explicar o mundo sem acudir à experiência será tão mal fundamentado quanto Descartes, que fracassara em sua física. ${ }^{94} \mathrm{Com}$ a religião não poderá ser diferente; e, sobre os pilares inabaláveis da experiência e do raciocínio analógico que nela se funda, é forçoso dar por certa a existência de um criador racional, pois há uma inegável analogia entre o mundo, que é muitíssimo bem engen-

92 Op. cit., p. 24.

93 Ibidem.

94 A este respeito é interessante notar que ainda na Introdução, e já em 1736, Butler assegura aos seus leitores que ele não procederá como Descartes, dando por óbvio que ele está errado ao não principiar a filosofia pela experiência: "Formar nossas noções da constituição e do governo do mundo com base em raciocínios, sem fundação para os princípios que assumimos, quer dos atributos de Deus, quer de qualquer outra coisa, é construir um mundo sobre hipóteses, como fizera Descartes." (Op. cit., p. 25.) Os Diálogos são quarenta anos mais jovens do que a Analogia, e, tratando-se da evolução do público leitor nesse ínterim, temos Mossner: "Na primeira metade do século XVIII, duas escolas de pensamento religioso floresceram na Igreja Anglicana: o grupo dogmático a priori modificando os sistemas filosóficos de Descartes, Espinosa e Leibniz [...] e o grupo a posteriori, mais recente, envolvendo uma filosofia religiosa a partir da fundamentação de Locke e melhor representada por Joseph Butler. [...] Ambos os grupos foram influenciados pela Nova Ciência, especialmente como conduzida por Isaac Newton; mas o primeiro estava mais impressionado por sua matemática, e o outro por seu empirismo. Entre líderes intelectuais importantes, o último grupo foi ganhando lentamente um domínio sobre o primeiro. Em 1750, a vitória estava virtualmente completa." "The Enigma of Hume", p. 335.) (Tradução nossa.) 
drado, e as máquinas de engenho humano. Como as nossas máquinas surgem do nosso engenho racional, através do raciocínio analógico está suficientemente provado que o mundo também tem um engendrador racional. Provar deste modo a existência de Deus era o que fazia aquilo que, no século XVIII, se chamava "teísmo experimental". À moda atual, dizemos que esta é uma teologia fundada sobre o argumento do desígnio.

Leiamos agora a formulação de Cleantes, o teísta experimental dos Diálogos, para sua posição:

Olha o mundo à volta: [...] A curiosa adaptação de meios a fins através de toda a natureza se assemelha exatamente, embora muito exceda, às produções de engenho humano [...]. Uma vez, portanto, que os efeitos se assemelham uns aos outros, somos levados a inferir, por todas as regras de analogia, que as causas também se assemelham, e que o autor da natureza é dalgum modo similar à mente do homem, embora possuidor de faculdades muito maiores, proporcionadas à grandeza do trabalho que ele executou. (II, §5)

Não é difícil notar a semelhança com a posição do bispo Butler: sendo contundente em apontar o mundo, Cleantes também pode reivindicar um pedigree newtoniano de filósofo experimental. Como experiência também servirão as que temos de engenhos perfeitos criados por homens; e raciocinando conforme o guia de nossas vidas, a saber, o raciocínio analógico, inferimos que o mundo, o qual observamos ser um engenho perfeito, analogamente tem um criador racional. A diferença é que a grandiosidade do mundo em muito supera a dos engenhos humanos; portanto, novamente via analogia, temos que seu criador racional em muito supera o homem.

Não é de modo algum arriscado dizer que o parágrafo do qual retiramos a citação precedente contenha sozinho toda a tese de Cleantes repetida sem alterações ao longo dos Diálogos. 
Não obstante, os objetivos de Hume ao criar a personagem seguramente vão além de caracterizar Butler, pois de fato a gama daqueles que respaldam o argumento do desígnio era tão vasta quanto ilustre: ia desde advogados mais estudiosos até o então reputado maior de todos os filósofos, Isaac Newton.

\section{NEWTON, DEUS E HUME}

Embora Newton não tenha redigido obras com o propósito de estabelecer o teísmo experimental, podemos ver que ele o corrobora, chegando, por exemplo, a perguntar: "Terá sido o olho engendrado sem perícia em ótica?, e o ouvido sem o conhecimento dos sons?" Perante a negativa, dada por óbvia, conclui que "é manifesto pelos fenômenos que há um Ser incorpóreo, vivente, inteligente, onipresente, que, no espaço infinito, [...] vê intimamente as coisas em si mesmas", e portanto sua filosofia, que conhece os fenômenos, nos traz ao "conhecimento da primeira Causa" ${ }^{\prime 95}$. Decerto, o leitor hodierno estranhará o fato de o grande físico endossar especulação tão amadora. O porquê ficará claro se nos inteirarmos um pouco da discussão epistemológica da época; em especial, do embate encarniçado entre Newton e Leibniz que punha filósofos newtonianos e cartesianos em partidos opostos.

Anônimo e falando de si em terceira pessoa sobre um texto em que suas próprias ideias eram defendidas, Newton compara seu método ao de Leibniz e se defende das acusações que lhe são feitas por este cartesiano. Interessa-nos aqui a de em toda as suas leis e princípios não haver explicações de causas últimas, consistindo portanto em "milagres ou qualidades ocultas" 96 - entre essas "maravilhas e absurdidades" 97 , mesmo, estava nada menos do que a lei da gravidade. Para Newton, a discordância entre ele e

\footnotetext{
95 NEWTON, Opticks, p. 369-70. (Tradução nossa.)

96 NEWTON, "An account of Commercium Epistolicum”, p. 224. (Tradução nossa.)

97 Ibidem.
} 
Leibniz era em grande medida uma questão de método: enquanto o filósofo matemático de formação cartesiana demandava causas para a priori inferir seus efeitos, Newton remetia ao grande mote dos Principia, "Hypotheses non fingo". Enquanto para Newton devemos formar nossas teorias a partir dos fenômenos, tomados por efeitos, e por estes descobrir as causas, pelo método de Leibniz, ao contrário, se deduziam a priori os efeitos a partir duma causa prima estabelecida previamente, à qual chamamos de Deus. Aos olhos cartesianos, o "método" newtoniano seria uma mera indução nada explicativa, já que, sem dar as razões, com suas leis apenas descrevia aquilo que qualquer um vê no mundo: objetos cadentes, raios de luz... Mas, por que a natureza se porta tal como vemos, continuamos sem saber; o que causa a lei da gravidade, tampouco.

Newton se defende: "devem as Leis constantes e universais da Natureza, se derivadas do poder de Deus ou da ação duma causa ainda desconhecida para nós, ser chamadas de milagres ou qualidades ocultas? Isto é dizer maravilhas e absurdidades?"98 Derivar do poder de Deus as leis newtonianas é aqui a condição para que elas não possam ser depreciadas por sua falta de caráter explicativo; assim, ele poderá se contrapor a Leibniz em pé de igualdade no que respeita à fundamentação, dizendo que

um ensina que filósofos devem argumentar a partir de fenômenos e experimentos até as suas causas, e então às causas dessas causas, e assim por diante até chegarmos à primeira Causa; o outro, que todas as ações das primeiras causas são milagres, e que todas as leis impressas na natureza pela vontade de Deus são milagres e qualidades ocultas, e portanto não devem ser consideradas em filosofia ${ }^{99}$

\footnotetext{
98 Ibidem. O "se" é grifo nosso.

99 Ibidem.
} 
Se as causas só podem ser descobertas via observação de fenômenos e Deus é uma causa, então temos que poder descobri-lo a partir do mundo. Como fazer tal descoberta torna-se uma questão, e sua resposta é o teísmo experimental.

Ora, sendo Hume nalguma medida um newtoniano notório, talvez fosse de esperar que endossasse o teísmo experimental. Veja-se que, desde o subtítulo do Tratado da natureza humana ele descreve seu intento como "Uma tentativa de introduzir o método experimental de raciocínio nos assuntos morais", i.e., nos assuntos filosóficos, mas alheios à filosofia natural. Embora nesse livro ao descrever seu empreendimento Hume não mencione Newton, não é difícil para os leitores colocá-lo como um newtoniano quer no que diz respeito ao projeto epistemológico, quer no que diz respeito ao método. A situação da filosofia, conforme nos contava, era a mais desanimadora possível:

O homem dotado de discernimento e de saber percebe facilmente a fragilidade do fundamento até mesmo daqueles sistemas mais bem aceitos e com as maiores pretensões de conter raciocínios precisos e profundos. Princípios acolhidos com base na confiança, consequências deles deduzidas de maneira defeituosa, falta de coerência entre as partes e de evidência no todo - tudo isto se pode encontrar nos sistemas dos mais eminentes filósofos, e parece cobrir de opróbrio a própria filosofia. (THN, Int., §1)

Tratava-se, pois, dum modo de raciocinar a desgraçar a filosofia. Começava-se com a assunção arbitrária de princípios e continuava com más inferências - e isto entre os mais eminentes filósofos! Por que teriam grandes gênios cometido erros crassos? Pela retórica algo cartesiana deste fragmento, vemos serem os maus fundamentos e os maus métodos. No Tratado, Hume tentara resolver o problema com uma ciência fundamental, a ciência do homem, e, por sua vez, "o único fundamento sólido que pode- 
mos dar a ela deve estar na experiência e na observação." (THN, Int., §7) Eis aqui, portanto, a introdução do método experimental.

Hume determina tal método desde o começo do Tratado, colocando as seguintes normas: (1) temos que "tornar todos os nossos princípios tão universais quanto possível", (2) "explicar todos os efeitos pelas causas mais simples e em menor número" e ainda que (3) "qualquer hipótese que pretenda revelar as qualidades originais e últimas da natureza humana deve imediatamente ser rejeitada como presunçosa e quimérica." (THN, Int. §8) Com efeito, "muitas características enigmáticas da metodologia de Hume se tornam menos enigmáticas quando as colocamos no contexto das regras newtonianas" ${ }^{\prime 100}$ : se compararmos às normas 1 e 2 acima as regulæ philosophandi I, segundo a qual "não devemos admitir mais causas de coisas naturais do que as que são tanto verdadeiras quanto suficientes para explicar suas aparências" pois "a natureza se apraz com a simplicidade e não afeta a pompa de causas supérfluas"101, e II, que diz que "para os mesmos efeitos naturais, devemos, tanto quanto possível, atribuir as mesmas causas"102.

Entretanto, se comparado ao de Hume, no método de Newton há uma ausência bem notável: não encontramos em suas regras nenhuma que equivalha àquela terceira regra humeana; nenhuma que vede a descoberta de causas últimas e decrete um ponto final para as investigações que não seja o conhecimento da causa do todo. Para Newton, de fato: se as causas só podem ser descobertas via observação de fenômenos e Deus é uma causa, então temos que poder descobri-lo a partir do mundo; como fazer tal descoberta torna-se uma questão, e de fato sua resposta terá de ser o teísmo experimental.

\footnotetext{
100 PASSMORE, Hume's Intentions, p. 43. (Tradução nossa.)

101 NEWTON, The Principia, 1995, p. 320. (Tradução nossa da versão inglesa.)

102 Ibidem.
} 
Mas, se as causas últimas simplesmente não podem ser descobertas, o teísmo deixa de ser necessário à filosofia de Hume.

\section{HUME VERSUS BUTLER}

Situação adversa seria a de Adão, fosse ele trazido ao mundo subitamente e já adulto. Mesmo que com sua razão seja capaz de resolver os cálculos mais complexos, ao deparar-se pela primeira vez com o mundo,

ele observaria imediatamente uma contínua sucessão de objetos, e um evento a seguir outro, mas não conseguiria descobrir mais nada além disto. El[e] não seria, no início, capaz de apreender por meio de qualquer raciocínio a ideia de causa e efeito [...], e não é razoável concluir, meramente porque numa determinada ocasião um evento precede outro que portanto um deles é a causa e o outro efeito. (EHU, V, §3)

Que dois e três somados resultem no mesmo que quinze dividido por três é coisa mais que sabida e consabida: é coisa impossível de ser negada sem absurdo, sem que se atente contra a razão da qual nós e o nosso Adão somos dotados. Servindo-nos desta, podemos efetuar cálculos idênticos quer tenhamos nascido no século XVII ou no XXI, quer na Escócia, na Índia ou no Brasil. O mundo, contudo, não é assim tão universal: lapões e negros da época de Hume não faziam ideia de que o vinho embebeda, nem a um príncipe indiano poderia parecer razoável crer que a água em algum momento ficasse sólida, mesmo se for muito esfriada.

Ora, é perfeitamente imaginável que ingiramos litros de vinho e não nos embebedemos, que a água se muito esfriada não se solidifique - podemos mesmo imaginar que ela se transforme em vinho e, se bebermos litros deste, nos teletransportemos para a Lapônia. Decerto, dificilmente são críveis tais extravagâncias, mas nada impede que as imaginemos. Caso contrário é o do triângulo cuja hipotenusa não seja a soma dos quadrados dos ca- 
tetos, ou o da igualdade entre $5 \times 1.000$ e 2 - 3. Já sabemos o que Butler diria aqui: nos primeiros casos, trata-se de evidências prováveis, i.e., que comportam vários níveis de assentimento, ao passo que nestes últimos trata-se de evidências demonstrativas, i.e., que podem ser apenas afirmadas ou negadas. Para ele, então, se quisermos saber de qual destes tipos é uma proposição, basta que vejamos o grau de assentimento que lhes conseguimos dar.

O teste, bem como a classificação, para Hume são outros. "Todos os objetos da razão ou investigação humanas", dirá ele, "podem ser naturalmente divididos em dois tipos, a saber, as relações de ideias e as questões de fato." (EHU, IV, i, §1) As afirmações a respeito das primeiras são aquelas da geometria, da aritmética e da álgebra. Estas, as únicas demonstráveis, reservam para si verdade ou falsidade necessárias, pois "mesmo que não existisse um círculo ou triângulo na natureza, as verdades demonstradas por Euclides conservariam para sempre sua certeza e evidência." (ibidem) Contudo, o contrário duma questão de fato nunca implica contradição, e portanto é impossível tentar demonstrar sua verdade ou falsidade. Assim, se quisermos saber se uma proposição se refere a uma questão de fato ou a uma relação de ideia, temos de considerar que "o que quer que concebamos é possível, ao menos num sentido metafísico, mas onde ocorre uma demonstração, o contrário é impossível, e implica uma contradição" (A, §11). Se uma proposição tiver contradição possível, trata-se duma questão de fato, e se não, duma relação de ideias.

Embora reserve a necessidade às relações de ideia, Hume não faz isto com a certeza: ele recusa uma divisão dos argumentos apenas entre demonstrações e probabilidades, mas inclui entre estas também as provas, "entendendo-se por provas aqueles argumentos a partir da experiência que não deixam margem à dúvida ou oposição." (EHU, VI, n.1) Noutras palavras, rememorando Butler: embora não possamos demonstrá-lo, assentimos com 
toda força a que o sol nasça amanhã. Ora, como dizíamos, Adão poderia fazer cálculos; mas, mesmo sendo perfeitamente racional, não poderia saber que o sol nascerá amanhã. Trata-se duma questão de fato, pois podemos imaginar que ele não nasça, ou que nasça quadrado, ou ainda que não exista. Será que podemos, sendo humeanos, admitir a explicação de Butler segundo a qual isto seja causado pelo raciocínio analógico?

Que seja por meio de qualquer raciocínio, analógico ou demonstrativo, dirá Hume que certamente não. Ele até admite, qual Butler, que

sempre supomos, quando vemos qualidades sensíveis idênticas [like], que elas têm idênticos poderes secretos, e esperamos que delas se sigam efeitos semelhantes àqueles de que tivemos experiência. Se nos for apresentado um corpo de cor e consistência idênticas à daquele pão que antes comemos, não hesitaremos em repetir o experimento, antevendo com certeza a mesma nutrição e sustento. (EHU, IV, §16)

Mas as semelhanças cessam aqui, e uma discordância de Butler se faz manifesta. Sabemos que raciocínios relativos a questão de fato, para Hume, se assentam na relação de causa e efeito, pois se vemos um relógio numa ilha deserta e inferimos que um homem já esteve lá, se ouvimos uma fala racional no escuro e inferimos que há uma pessoa, é porque relógios e falas racionais procedem exclusivamente de seres humanos, ou seja, são efeitos cujas causas experimentamos serem exclusivamente humanas. A experiência e a semelhança têm seu papel fundamental; uma por sermos incapazes, apenas olhando o fogo sem jamais tê-lo tocado, de inferir que ele queima, e outra por sempre podermos ao ver um objeto semelhante ao fogo tomá-lo novamente por fogo. O que fazemos, no entanto, não é um raciocínio, a menos que queiramos dizer que os filósofos foram por tanto tempo incapazes de explicá-lo mesmo que sejam efetuados por bebezinhos - pois 
estes, tocando o fogo, não ousam repetir o experimento. Hume admite (cf. EHU, IV, §16) que da proposição "Constatei que tal objeto foi seguido por tal efeito" pode-se passar a esta outra de que "Prevejo que outros objetos, de similar aparência, serão seguidos por efeitos semelhantes". "Mas," diz ele desta passagem,

se alguém insistir que ela se faz por meio de uma cadeia de raciocínios, muito gostaria que esses raciocínios me fossem apresentados. A conexão entre essas proposições não é intuitiva. É preciso aqui um termo médio capaz de permitir ao espírito realizar tal inferência, se é que de fato ela é extraída por algum raciocínio ou argumento. Qual seria esse termo médio, devo confessar que ultrapassa a minha compreensão, e a quem compete apresentá-lo são aqueles que afirmam que ele realmente existe e é a origem de todas as conclusões relativas a questões de fato. (ibidem)

Temos, então, Butler em maus lençóis: se o raciocínio analógico é o grande guia de nossas vidas, somos forçados a concluir que bebês raciocinam, fazem inferências e extraem conclusões ao esperarem do leite materno a mesma nutrição de sempre.

Semelhança e experiência, pois, são sozinhas condições necessárias mas não suficientes para explicar o porquê de das mesmas causas esperarmos os mesmos efeitos. "Os ovos", por exemplo, "assemelham-se entre si como nenhum outro objeto, e ninguém, no entanto, espera encontrar em todos eles o mesmo gosto e sabor." (EHU, IV, ii, §20) Já a mera experiência de repetições, por sua vez, também não basta; afinal, se supusermos que o nosso Adão

tenha adquirido mais experiência e tenha vivido no mundo o suficiente para observar que objetos e acontecimentos similares uns com os outros[, q]ual é a consequência desta experiência? Que el[e] passa a inferir a existência de um objeto do aparecimento do outro. No entanto, com toda a sua experiência 
el[e] não terá adquirido qualquer ideia ou conhecimento do poder secreto pelo qual o primeiro objeto produz o segundo, e não é por qualquer processo de raciocínio que é levad[o] a realizar esta inferência. Apesar disto, [...] vê-se obrigad[o] a realizá-la. (EHU, V, §4)

Ora, desde muito antes do surgimento da física espera-se que o sol nasça; e desde muito antes da química, que o pão nutra. Portanto, sabermos que o sol nasce e que o pão nutre não pode implicar conhecermos os motivos disto ou as características dos objetos aos quais isto sucede; ou seja, não pode implicar qualquer conhecimento ou cadeia de raciocínios acerca das questões de fato. Na verdade, raciocinarmos é mesmo indiferente para "inferirmos" certas coisas. Para explicar por que fazemos inferências como a de que se o sol sempre nasceu ele seguirá nascendo ou a de que se o pão sempre nutriu ele seguirá nutrindo, torna-se forçoso concluir que "há algum outro princípio que nos obriga a chegar a esta conclusão." (ibidem) Tal princípio, dirá Hume sem meias palavras, é o hábito (cf. EHU, V, i, §5). Estamos habituados a ver o sol nascer todos os dias; apenas por isto, sem cálculos nem analogias, estamos certos de que ele nascerá amanhã. Assim, para o raciocínio acerca de questões de fato serão necessários (1) a experiência de conjunção entre dois eventos no passado, (2) a semelhança e (3) o hábito, certo instinto que faz universalizarmos temporalmente a experiência passada.

É, pois, até compreensível que se chame Hume de empirista, embora devamos também atentar ao fato de que ele, ao falar de experiência, não se preocupe com uma existência do mundo ou de objetos reais que deem origem às percepções. Aquilo que chamamos de experiência são as percepções da mente, as quais se dividem em impressões e ideias: as primeiras, mais vívidas, são aquilo que percebo agora - sejam os corpos que vejo ao redor, sejam meus sentimentos -; as ideias, menos vívidas, são aquilo em que penso. E que toda ideia corresponde a alguma impressão 
vemos porque "todos os materiais do pensamento são derivados de nosso sentimento interno e externo" (EHU, II, §5), sendonos impossível pensar algo jamais percebido dalguma maneira. ${ }^{103}$ Mas, ao invés de fazer simples descrição psicológica, Hume faz também uma regra para determinar se um termo filosófico tem significado: se à suposta ideia de um termo não corresponder impressão alguma, é porque na verdade não se tratava duma ideia e o termo não tem significado. (Cf. EHU, II, §9) Assim, se falarmos de Deus considerando-o um ser benevolente, estaremos usando o termo com um significado, pois temos impressão da bondade; mas, se dissermos que Deus é um ser tão supremo que completamente distinto de qualquer coisa jamais percebida, usamos o termo sem qualquer significado. Esta regra segundo a qual toda ideia tem que corresponder a uma impressão serve para "banir todo aquele jargão que por tanto tempo dominou os raciocínios metafísicos e os fez cair em desgraça." (EHU, II, §9)

\section{O CETICISMO ACADÊMICO DE HUME}

Ora, porquanto excluímos a racionalidade do âmbito das questões de fato, terá o aval de Hume todo ataque a argumentações apriorísticas sobre elas. Para ele, não pode haver cogito algum que nos dê qualquer tipo de segurança acerca da realidade - isto, que basta para colocá-lo contra toda a metafísica tradicional, basta para que ele se considere muito cético (Cf. A, \$26). Se Hume fosse apenas um crítico da racionalidade, concordaria com uma pirrônica suspensão de juízo quanto a teses filosóficas que assegurem a veracidade dos sentidos e ao mundo exterior, pois, assim como temos motivos para crer neles, sobram motivos para que duvidemos deles. É crença do vulgo, por exemplo, que as nossas percepções e os objetos percebidos são o mesmo,

103 Quanto às sereias, nunca vistas porém pensáveis, as partes que a compõem são ideias de coisas já vistas. E, mesmo que se tratasse de animal inteiramente extravagante, haveríamos de ter no mínimo ideia das suas cores. 
mas essa opinião universal e primária de todos os homens é logo destruída pela mais ligeira filosofia, a qual nos ensina que nada pode estar presente à mente a não ser uma imagem ou percepção, e que os sentidos são apenas os canais de entrada pelos quais estas imagens são conduzidas, sendo incapazes de produzir qualquer comunicação direta entre o espírito e o objeto. (EHU, XII, i, §9)

Tanto é que quando vemos uma mesa de perto e, ao nos afastarmos dela, vemo-la menor, não cremos serem mesas diferentes mesmo que tenhamos percepções diferentes suas, mas sim que há uma única mesa real cujas imagens mudam quando mudamos de posição e que permanece a mesma independentemente do nosso ponto de vista.

O cético pirrônico - aquele que levanta objeções a teses filosóficas de modo a não assentirmos a nenhuma delas -, é imbatível dentro dum cenário exclusivamente racional, e isto significa que ele é imbatível frente quaisquer debatedores metafísicos: a estes, sempre poderá dizer acerca, por exemplo, da demonstração da passagem da percepção de objetos à sua existência, que "não sois capazes de satisfazer a vossa razão, a qual continua a ser incapaz de encontrar, a partir da experiência, qualquer argumento convincente para provar que as percepções estão conectadas com quaisquer objetos exteriores." (EHU, XII, i, \$14)

No entanto, Hume não se limita ao papel negativo de crítico da racionalidade: vimos já seu intento de constituir uma ciência da natureza humana que busca através da experiência e duma “observação cuidadosa da vida humana” (THN, Int., §10) estabelecer princípios da natureza humana - e fora já observado algum ser humano que de fato duvidasse da existência do mundo exterior ou da causalidade? Naturalmente que não, pois "toda a vida humana seria aniquilada se os seus princípios [i.e., do pirrônico] fossem adotados de forma constante e universal" (EHU, XII, ii, §23), com povos famintos duvidando da tese de que o pão ali- 
menta, saindo pela janela e não pela porta por não ser demonstrável que os corpos se machuquem com a queda. ${ }^{104}$

Certamente há uma concordância da parte de Hume com o pirronismo em ao menos um aspecto: podem-se, por via racional, pôr em dúvida a existência independente de objetos exteriores e a confiabilidade dos sentidos. Mais ainda, podemos até experimentar negá-las: que os sentidos não sejam plenamente confiáveis, percebemos através dos experimentos mais triviais - seja provar o vinho ora estando doente, ora estando saudável, para notar como o sabor muda malgrado não suponhamos que o vinho mude de propriedades conforme a nossa saúde, seja apertar o olho para ver as impressões se duplicarem, malgrado não creiamos duplicarem-se também os objetos. Ora, as únicas coisas a que temos acesso dos objetos cujas existências presumimos são as impressões - sejam estas de cor, som, cheiro ou sabor. E "quando excluímos essas qualidades sensíveis, não resta nada no universo que possua tal existência." (THN, I, iv, 4, §15) Não há, pois, uma base racional para afirmar a existência de um mundo exterior, de seus objetos ou mesmo que eles amanhã serão regidos pelas mesmas leis físicas que sempre os regeram.

Por outro lado, não haver uma base racional para afirmar essas existências não implica não haver base alguma. Os princípios do ceticismo pirrônico têm uma subversora que seja não a razão, mas sim

104 Decerto, não era consequência do pirronismo duvidarmos das coisas quotidianas - e Hume, que cita Sexto com referência detalhada, dificilmente ignoraria isto. Ao invés de presumirmos essa improvável ignorância da parte de Hume, mais vale atentar à cobrança que ele faz de um resultado para a adoção de princípios filosóficos. O problema do pirronismo há de ser, então, o de não ter consequência prática possível - ao contrário das tantas outras escolas da Antiguidade, que pretendiam ter implicação moral, e, por que não, da filosofia do próprio Hume, que condena o monoteísmo como nocivo à moralidade, à razão e à política (cf. NHR, IX-XIV). 
a ação, juntamente com os afazeres da vida diária. Esses princípios podem florescer e triunfar nas escolas, onde, de fato, é difícil refutá-los, se não até mesmo impossível. Mas logo que deixam a sombra e são colocados, pela presença dos objetos reais que estimulam as nossas paixões e sentimentos, em confronto com os princípios mais poderosos da nossa natureza, desvanecem-se como fumo e deixam o cético mais persistente numa condição igual à dos outros mortais. (EHU, XII, ii, §21)

Embora tenha grande força de um ponto de vista racional exclusivo, este ceticismo sucumbe aos princípios da natureza humana, que não permitem duvidarmos da existência do mundo, de esta continuar sem nós ou de aquilo que vemos corresponder a objetos reais. Hume, então, não é um pirrônico. Caso nos perguntemos se não deveria ser justamente isto o que é imprescindível em filosofia - ser válido do ponto de vista racional - e que, portanto, em questões filosóficas devemos adotar princípios pirrônicos, a resposta é em parte, novamente, a força da natureza:

A natureza é sempre mais forte do que os princípios. [...] Quando [o pirrônico] desperta do seu sonho, ele é o primeiro a rir de si próprio e a confessar que as suas objeções constituem mera distração, e tendem somente a mostrar a estranha condição da humanidade, que precisa de agir, de raciocinar e de acreditar, sem ser capaz, mesmo pelas mais diligentes investigações, de ficar satisfeita com a explicação do fundamento dessas operações (EHU, XII, ii, §23)

Todos os homens estamos sempre com nossa razão atropelada pela natureza, nessa condição caprichosa que nos obriga a crer sem qualquer fundamento racional; a crer, p. ex., que o mundo existe, que os nossos sentidos nos informam verdadeiramente sobre objetos que existem e o ocupam, que o pão alimenta ou que as mesmas leis físicas que regeram o passado regerão o futuro. No entanto, não precisamos ficar inertes em filosofia, saben- 
do-a sempre fadada ao fracasso quando confrontada com a natureza: há ainda outra espécie de ceticismo, o chamado mitigado ou filosofia acadêmica.

A maneira então de escapar ao embaraço tanto pirrônico quanto metafísico é adotarmos de antemão, sem dúvidas filosóficas, as crenças que somos forçados por natureza a adotar, e assim evitar as questões que inquirem além do que pode ser respondido: "um correto juízo", então, evita "todas as indagações remotas e elevadas, limita-se à vida comum e aos objetos que se apresentam à prática e à experiência quotidianas". (EHU, XII, iii, §25) Tal postura Hume chama de filosofia acadêmica ou ceticismo mitigado.

Há, pois, que por um lado reconhecer os limites da razão, recusando-se a demonstrar questões de fato e a investigar aquilo que está além do seu alcance, mas por outro reconhecer também que é inútil (e do ponto de vista prático, impossível) negar todo tipo de crença, e, frente às nossas estreitas limitações, abraçar aquelas crenças que são imposições da própria natureza humana - a de que os corpos existem, que a natureza no futuro se assemelhará à natureza passada. Mas não a de que deuses existem.

\section{UM DÉJÀ-VU DA ANTIGUIDADE}

Quando Hume fala que é um filósofo acadêmico e nomeia personagens como Filão e Cleantes, ele evoca textos clássicos. Assim, embora uso sinonímico de "ceticismo" e "acadêmico" pareça estranho a leitores de hoje, para os quais a Academia fundada por Platão remete antes de tudo ao platonismo, se soubermos que esta mesma Academia durou o suficiente para que tivesse diversos escolarcas e que os derradeiros foram céticos, a escolha de Hume fará muito mais sentido. E quando soubermos que o último desses céticos se chamava Filão, xará do cético dos Diálogos, torna-se mais pertinente inteirarmo-nos do ceticismo acadêmico. 
Para fazê-lo, a fonte será Academica de Cícero, uma vez que este fora aluno de Filão, e que dos próprios escolarcas não restaram escritos. Cícero redigiu-a em forma de diálogo de modo a contrapor a filosofia acadêmica à estoica e, ao cabo, apontar o sucesso da primeira e o embaraço da segunda no trato das mesmas questões filosóficas. As personagens antagônicas que veremos são o próprio Cícero, que defende a Academia, e o general Luculo, que defende Antíoco de Ascalão, um eclético de viés estoico.

Para importar uma discussão grega, Cícero precisou cunhar em latim um vocabulário filosófico; e como muitas dessas inovações continuam vivas, encontram no texto ciceroniano sua certidão de nascimento - mas não necessariamente com o mesmo significado pretendido pelo filósofo. Preocupamo-nos aqui com um deles: comprehensio, compreensão. Originariamente comprehendere era um verbo apenas transitivo, com o sentido de segurar, prender com as mãos, assim como $\kappa \alpha \tau \alpha \lambda \alpha \mu \beta \alpha ́ v \omega$ era

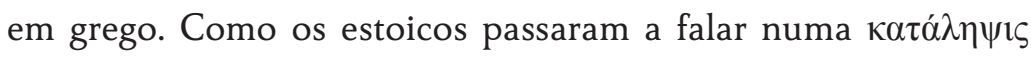
feita pela mente, ao traduzir o termo Cícero escolheu comprehensio, vindo daí o nosso uso de "compreensão" como sinônimo de entendimento e também o uso intransitivo do verbo. Vale, pois, ter em mente que quando este uso do termo era um ineditismo à época. Sendo metáfora de um gesto físico, implicava sempre que quem compreende compreende algo; pressupunha-se, enfim, que há algo de objetivo a ser compreendido.

É Luculo quem começa a disputa levantando objeções à Academia, queixando-se mais especificamente das alterações feitas por Filão na filosofia que ali se ensinava. Ele começara a dizer que nada podia ser compreendido, ao invés de negar apenas a possibilidade da definição daquilo que se compreende. De acordo com os estoicos, aquilo que compreendemos, i.e, seguramos com nossas mentes, são os objetos reais que existem independentemente dos nossos sentidos, e então, quando os compre- 
endemos, é através dos nossos sentidos impressa em nós uma representação ou ideia verdadeira. Assim, "quando Filão abala e tolhe isto, tolhe o juízo do conhecido e do incógnito, donde resulta que nada pode ser compreendido" (Ac., II, 18).

A epistemologia estoica vai além em sua pretensão de conhecimento verdadeiro: podemos descobrir classes entre as representações. Quando dizemos que certas coisas são brancas ou azuis ou cheirosas, estas, como Luculo diz, são "compreendidas com nossa mente, não com nossos sentidos" (Ac., II, 21), e então, unindo essas representações, nossa mente compreende outras mais sofisticadas como cavalos e homens, e finalmente "se segue uma série ligando preceitos maiores [...] que abraçou quase inteiramente a compreensão das coisas: 'Se é humano, é um animal mortal participante de razão.'” (ibidem) Com os estoicos temos então um caminho pleno de certeza e conhecimento verdadeiro que nos permite pronunciar acerca do mundo e de suas coisas através de lógica proposicional; noutras palavras, podemos dizer que partimos de sentidos verdadeiros e construímos uma espécie de conhecimento cogente do mundo com eles. Negar confiabilidade aos sentidos, portanto, implica arruinar as fundamentações do estoicismo.

Luculo deve, então, insistir bastante em sua confiabilidade. Por isso chega a defender que se fôssemos postos perante um deus não poderíamos ser capazes de pedir sentidos melhores do que os que temos (cf. Ac., II, 19) e argumenta que, malgrado alguns erros como o do graveto que parece estar quebrado quando posto na água ou nossa confusão ao ver gêmeos idênticos, podemos confiar neles se formos sábios e nos treinarmos. Afinal de contas, "quando nos valemos de exercício e arte, como não são tidas as pinturas pelos olhos e as canções pelos ouvidos?, quem não pode discernir quanta força há nos sentidos?" (Ac., II, 20) Uma vez que temos conhecimento verdadeiro disponível através dos sentidos, a consequência deve ser a de que homens 
sábios não formam opiniões ou assentem a probabilidades, essas intermediárias de ignorância e conhecimento. O homem sábio apenas sabe.

Dois pontos serão atacados na doutrina estoica: em primeiro lugar o seu fundamento, recusando-se a confiabilidade plena aos sentidos; em segundo, ataca-se a própria consequência prática a que a doutrina leva, a saber, a de que não agimos ou tomamos decisões com base em probabilidades.

Cícero começa sua refutação da tese estoica minando a confiabilidade dos sentidos insistindo naqueles (agora) velhíssimos tópicos que provam que os sentidos, por si sós, não são inteiramente confiáveis: o graveto que parece estar partido quando posto n'água, o pescoço do pombo que às vezes parece ser branco e às vezes colorido etc. (cf. Ac., II, 79). Se os sentidos uma vez mentiram, não pode haver razão para crer em sua infalibilidade. O próximo passo, mais íntimo à tese estoica, é negar a existência dalgum modo de distinguir as representações que correspondem a algo real das que não correspondem a nada. Para fazê-lo, tudo de que Cícero precisa é apontar ilusões de loucos e bêbados, sonhos realistas, ovos e gêmeos idênticos. Como não podemos distinguir representações com certeza, então nada podemos compreender ou segurar com nossas mentes.

No entanto, diferentemente da imagem clichê do cético no seu gabinete duvidando de seus próprios sentidos, Cícero enfatiza que a certeza é desnecessária para a ação. De fato, segundo ele não é nem a inconfiabilidade dos sentidos que destrói completamente a doutrina estoica, mas sim o "sistema de Carnéa$\operatorname{des}^{\prime \prime 105}$ (Ac., II, 98), que abole a dicotomia entre representações verdadeiras e falsas e introduz a probabilidade. "Assim, aquilo que vier a ocorrer com ideias prováveis - se nada que seja con-

105 Carnéades foi outro escolarca cético da Academia. Aquele que queira inteirarse mais do assunto lerá com prazer Os céticos gregos, de Victor Brochard, e Acadêmicos versus Pirrônicos, de Roberto Bolzani Filho. 
trário a tal probabilidade se oferecer - será usado pelo sábio, e assim se governará todo o cálculo (ratio) da sua vida." (Ac. II, 99) A adequação do sistema de Carnéades é ainda mais evidente porque se precisássemos compreender nossas percepções e, consequentemente, ter certeza, "toda a vida seria tolhida" (ibidem). Ademais, pode-se perguntar como o sábio estoico seria capaz de ignorar representações que ele não sabe se são verdadeiras, "pois ele não é esculpido em pedra ou entalhado em madeira; ele tem um corpo, tem uma alma, é movido por uma mente, é movido por sentidos, de modo que muitas coisas lhe parecem verdadeiras". (Ac., II, 100) Como um ser humano, afinal, o sábio age, e age sem certeza. Desde Carnéades, o sábio é aquele que sopesa probabilidades quando age ou filosofa.

Ora, em Academica, pelo menos duas das questões disputadas por acadêmicos e estoicos nas pessoas de Cícero e Luculo são íntimas à epistemologia de Hume: a confiabilidade dos sentidos e a dependência de conhecimento verdadeiro para a ação. A resposta à primeira, ao que tudo indica, leva a uma postura absolutamente contrária à de Hume: colocar em cheque a confiabilidade dos sentidos. No entanto, cabe notar que não podemos nos apressar em, valendo-nos do vocabulário humeano, dar o nome de pirrônico a Cícero; afinal, há em primeiro lugar que se levar em consideração o adversário do seu discurso, que é o estoicismo. Se, para o adversário de Cícero, pelos sentidos somos capazes de conhecer a realidade das coisas, é claro que ele há de reforçar a falibilidade dos sentidos.

Tratando das percepções, Luculo questiona: "O que se pode dizer de tão absurdo quanto o que eles [i.e., os acadêmicos] falam: 'É verdade que isto é um signo ou prova daquele objeto, e portanto sigo-o; mas é possível que a coisa que ele significa seja falsa ou de todo inexistente.'?" (Ac., II, 36) Esta afirmação que causa certa repulsa ao estoico pode ser traduzida para o linguajar hodierno como a de que, apesar de crermos em nossas sensações, 
não podemos garantir sua correspondência com objetos reais. É, pois, uma tese a cuja negação ninguém hoje se atreve - e é a tese que, no linguajar ciceroniano, se abraça ao assentir a uma representação. A retenção de assentimento é apenas a negação de uma tese estoica muito forte, e o assentimento é aquilo sem o que não se podem compreender objetos reais (cf. Ac., II, 36). O assentimento é sempre um assentimento a uma representação, é dá-la por cópia correta de um objeto externo real.

A epistemologia estoica faz, pois, uma verdadeira confusão entre o que mais tarde chamaríamos de lógica e de questões de fato; assim, tanto faz sentido dizer que fatos, objetos e representações sejam verdadeiros quanto pode ser natural a um ceticismo moderado negar a verdade das representações. Devemos ademais chamar atenção ao fato de que a crença não vem à baila na discussão do assentimento: assentir a algo é tão-somente dar algo por verdadeiro. Não temos, por fim, como defender que "a intenção de Cícero era justamente mostrar que é possível viver sem crer"106, pois além de ele ter estranhado a afirmação de tal possibilidade, o próprio fato de ser possível agir (ou, se quisermos, viver) é enfatizado a fim de demolir a epistemologia estoica. Como será, afinal, que o sábio quando desce ao barco tem o conhecimento de como transcorrerá sua viagem? (cf. Ac., II, 100) O que Cícero pretende negar não é que creiamos nas sensações, mas tão-somente que elas sejam cogentes. E não bastasse isto, ao cabo temos um argumento contra a epistemologia estoica que poderia ter sido tirado da Investigação sobre o entendimento humano: se precisarmos de certezas para as nossas ações, toda a vida será abolida, e é a nossa natureza - humana, e não pétrea - que nos faz dar por verdadeiras as sensações.

Hume, naturalmente, também causaria indignação a Luculo, pois sabemos que ele também afirma que agimos em conformidade com nossos sentidos malgrado não possamos assegurar a

106 SMITH, O ceticismo de Hume, p. 264. 
correspondência entre percepções e objetos percebidos. Como acadêmico, para Hume na prática os sentidos são críveis mesmo, mas não por qualquer motivo filosófico. Do ponto de vista filosófico eles são da mais absoluta contingência, e podemos descartar seu caráter necessário ao imaginarmos o contrário de tudo o que sentimos.

Para isto Hume é cético o suficiente. Havendo meios de discernir relações de ideias de questões de fato, tudo que não seja puramente matemático ou lógico ou geométrico pode ter suas reivindicações de verdade descartadas. Como a filosofia não é nem matemática, nem lógica, nem geometria puras, então todo sistema de filosofia pode ter suas reivindicações de verdade descartadas. Se pararmos por aqui, poderemos atirar no mesmo incêndio dos livros de teologia a Investigação sobre o entendimento humano.

É aqui que entra o ponto afirmativo da filosofia acadêmica exposta por Cícero: é dever do sábio sopesar probabilidades (e não verdades) ao filosofar. Para não atirarmos todos os sistemas filosóficos às fogueiras, havemos de sopesá-los, julgar suas asserções e formar as nossas próprias.

Para fazê-lo, devemos usar probabilidades: estas pertencem ao domínio das questões de fato mas não chegam a provas, pois não temos delas uma experiência exaustiva e invariável (cf. EHU, VI, n.1). Hume as divide em probabilidades de chances e de causas; as primeiras são as de que algo venha a acontecer - como a de um dado cair com uma determinada face voltada para cima - e as de que as causas tenham tais efeitos - como o de que o ruibarbo purgue. Assim, probabilidades são usadas para argumentar sobre questões de fato que não sejam tão certas quanto que o fogo queimará ou que pedras cairão. Questões de fato como a existência de uma providência e um criador inteligente, por exemplo. 
Enquanto os tópicos da metafísica tradicional que visam a estabelecer doutrinas filosóficas devem ser submetidos àquele "microscópio" (EHU, VII, §4) humeano que examina a legitimidade de suas ideias, aos do teísmo experimental caberá a crítica que se valha de probabilidades. E é assim, com raciocínios baseados em questões de fato e que não podem ser resolvidos apenas com a adoção de um vocabulário claro, que serão criticadas na Investigação pontos do teísmo experimental: a analogia como um modo de determinar questões de fato na Seção IX, providência particular e vida após a morte na Seção XI, e crença em milagres na Parte II da Seção X.

Em epistemologia, pois, o terreno apropriado de crítica por meio de probabilidades é aquele da religião natural, porquanto esta é a que alega resolver questões teológicas de modo experimental. Nada poderia ser mais adequado para ser criticado pelo ceticismo acadêmico. Não é por acaso que a personagem crítica nos Diálogos tem o nome de Filão.

Mas, se Cícero não dispunha de mecanismos para julgar relações de ideias e assim criticar uma teologia que sequer existia, já se valia ele do ceticismo acadêmico para criticar as existentes de então, a saber, a estoica e a epicurista. Nosso livro desta vez será o De natura deorum, onde Cícero presencia a discussão entre Veleio, Cota e Balbo, tratando-se de defensores respectivamente do epicurismo, da filosofia acadêmica e, como não, do estoicismo. $\mathrm{O}$ modelo decerto espelha o dos Diálogos sobre a religião natural: o autor, não tão escondido quanto o humeano, foge ao debate e torna-se narrador do diálogo, que também será reproduzido numa correspondência a um amigo, e ao cabo, nas linhas finais, o narrador conclui que quem está mais certo é um dos debatedores que não o cético. Até mesmo dois nomes de personagens têm seu duplo no debate do De natura deorum: Filão, como vimos, é o nome de um filósofo acadêmico que de fato existira, e também existiu um filósofo estoico chamado Cleantes. 
A grande questão discutida na obra, como indica o título, é a natureza dos deuses, que tem descrições conflitantes nas teologias epicurista e estoica. Enquanto Veleio exporá e defenderá a primeira e Balbo a segunda, Cota - acadêmico discípulo de Filão - desde o início avisa que "não sói vir à [sua] mente com tanta facilidade o motivo por que algo é verdadeiro quanto por que algo é falso" (ND, I, 57). Como aprendera com seu mestre a nada saber (cf. ND, I, 17), o papel de Cota no diálogo será não o de expositor, mas de crítico das doutrinas teológicas expostas. É interessante notar que alguns argumentos dessas teologias pagãs que sustentavam mitologias são usados ainda hoje por teologias cristãs para sustentar a sua religião, mesmo sendo as religiões tão diferentes entre si. Vejamos algum deles.

Para Veleio, é evidente que deuses existem porque isto é consenso: "Só [Epicuro] percebeu antes de todos que deuses existem porque suas noções foram impressas em todas as almas pela própria natureza. Pois qual é o povo ou raça de homens que não tenha, sem instrução, alguma antecipação dos deuses?" (ND, I, 43) Esta é provavelmente a única herança epicurista para teologias mais recentes. A estoica certamente terá sido mais profícua, incluindo mesmo o moderníssimo argumento do desígnio. Balbo elenca uma série de pontos para provar a existência divina, apesar de, para ele, ela "não precisar de argumento. O que pode ser tão manifesto e evidente quando contemplamos o céu e admiramos os corpos celestes quanto a excelentíssima mente do deus que os rege?" (ND, II, 4), e não bastasse isto, qual Veleio, aponta também o consenso da humanidade de modo a provar que um deus existe (cf. ND, II, 5).

Quanto a alguns destes pontos em particular, o que Cota tem a dizer é que (1) senso comum não deve ser base para teorias filosóficas e (2) na verdade nem se trata de um consenso, pois há filósofos que negam a existência divina e também povos em que ela não seja afirmada (cf. ND, I, xxiii). O argumento do desígnio, 
por sua vez, era desmantelado enquanto fundador da fé romana por, ao olharmos para o céu, não vermos por lá um indício de que seja regido por Júpiter em específico, e não por qualquer outra sorte de divindade (cf. ND, III, 11). ${ }^{107}$

\section{A EXAUSTIVA REFUTAÇÃO DO TEÍSMO}

Nos Diálogos sobre a religião natural temos três posições distintas acerca da existência e natureza divinas, cada uma exposta por um professor; porém, teses têm-nas somente Cleantes e Dêmeas. O professor Cleantes é o teísta experimental, cuja tese, a que florescia à época de Hume, já conhecemos: a perfeição do mundo prova a existência do criador, bem como a sua perfeição. O professor Dêmeas incorpora a metafísica tradicional, herdeira da escolástica; assim, seu recurso natural para argumentar sobre a existência divina é prová-la apenas pela lógica. Já para responder à questão acerca da natureza divina, Dêmeas toma a natureza humana por frágil, limitada e, se comparada ao Ser onipotente criador de tudo, dotada de flagrante inferioridade. Que poderia, pois, restar ao homem senão "adorar em silêncio suas [i. e., da deidade] perfeições infinitas que o olho não viu, a orelha não ouviu e tampouco adentrou o coração do homem conceber" (DNR, II, §1)?

Os meios de Dêmeas, pois, são opostos aos de Cleantes, embora compartilhem o fim de fundamentar filosoficamente as crenças religiosas. Enquanto o teísmo experimental de Cleantes aponta o mundo para provar a existência divina e afirma que Deus se assemelha aos homens, a velha metafísica de Dêmeas dispensa as contingências mundanas, nega qualquer conhecimento da natureza da deidade e garante-a por necessidade lógica, independente da experiência.

107 Para um cotejo detalhado dos argumentos de Cota e do Filão humeano, cf. PRICE, "Sceptics in Cicero and Hume". 
O professor Filão, ao contrário dos colegas, não tem uma tese teológica, mas, como cético, tem uma postura crítica. Importa notar que ele professa o ceticismo mitigado, pois reconhece que o cético sempre "terá que agir, [...] e viver e conversar como os outros homens, e para essa conduta não é obrigado a dar qualquer outra razão que não a absoluta necessidade sob a qual jaz de fazê-lo assim" (DNR, I, §9). Por causa de seu ceticismo, ele não porá em questão se este mundo existe mesmo ou se os sentidos são confiáveis: ele voltará suas dúvidas tão-somente para teorias filosóficas. Já de antemão, na Parte I, podemos ver qual seja a postura de Filão quanto à natureza de Deus ou a origem do mundo:

quando olhamos além das questões humanas [...], quando carregamos nossas especulações para ambas as eternidades [...] - para criação e formação do universo, a existência e propriedades de espíritos, os poderes e operações de um espírito universal existente sem início e sem fim, onipotente, onisciente, imutável, infinito e incompreensível -, precisamos estar bem afastados até da mais ínfima tendência de ceticismo para não ficarmos apreensivos por termos ido muito além do alcance de nossas faculdades. (DNR, I, §10)

Noutras palavras, não dá para ser cético - mesmo mitigado - e querer afirmar verdades teológicas. Na verdade, poderíamos já saber disto apenas com a Investigação, seguindo a seguinte cadeia: a pergunta pela causa do mundo é uma pergunta por uma relação de ideias ou por uma questão de fato? Ora, tanto não há demonstração matemática ou lógica possível para a existência do mundo como também é possível imaginar que ele não exista. Qual o nosso guia para o raciocínio concernente a questões de fato? Para Butler é a analogia: para ele, sim, basta observar semelhanças entre objetos para afirmar eles que têm causas semelhantes. Mas trata-se de Hume: para Hume é o hábito, o qual temos 
de fazer inferências causais, as quais, por sua vez, fundam-se em experiência prévia. Ora, ao hábito é necessária alguma experiência, nem que seja uma experiência singular! E temos sequer uma experiência do surgimento de um mundo? ${ }^{108}$

Contudo, os Diálogos não são uma redundância da Investigação: é apenas naqueles que Hume empreenderá uma refutação exaustiva do argumento do desígnio, ou teísmo experimental, pelas mais variadas vias. Vejamo-las.

\section{1) Analogia versus causalidade}

De fato, mencionar um fenômeno observável como o bom funcionamento do corpo humano contrasta o suficiente com silogismos e ontologias para podermos conferir o tão prezado adjetivo "experimental" à teoria que o faça. Comprometer-se com o rigor científico que usualmente acompanha pretensões de experimentadores, no entanto, não é coisa que Cleantes faça.

Já conhecemos a analogia fundada em experiência: observando o mundo, vemos que "a curiosa adaptação de meios a fins através de toda a natureza se assemelha exatamente, embora muito exceda, às produções de engenho humano"; assim, só podemos concluir, "por todas as regras de analogia" (DNR, II, §5), que as causas se assemelham também. Já sabemos igualmente que esse raciocínio analógico se dá conforme a filosofia de Butler

108 Esta objeção que tiramos a partir da filosofia desenvolvida nas seções II, IV e V da Investigação aparece também na boca de "um amigo que aprecia paradoxos céticos" (§1), na Seção XI: "Pergunto quem os transportou para as regiões celestiais [...] para que tão imprudentemente possam afirmar que suas divindades realizaram, ou irão realizar, algum propósito além do que efetivamente apareceu?" (§16) O plural aparece por o "amigo" se passar por Epicuro argumentando contra os religiosos atenienses. Mas, além de elas valerem também para o argumento do desígnio, de este ser descrito de maneira igual à dos teístas do séc. XVIII (cf. §11), o amigo argumenta igualmente contra um ponto ausente na religião grega: o da futurição (cf. \$21). Os que ignoram a censura terão aqui dificuldade em explicar o porquê deste expediente. 
e que é, digamos, estrangeiro à filosofia de Hume - e, ainda mais do que isso, que é criticado nela.

Assim sendo, o que Filão fará antes de discutir a inferência da analogia é traduzi-la para a filosofia humeana: ele a transformará, agora, numa relação de causa e efeito. Nosso cético usa o expediente de imaginar aquele que Hume chama de Adão, o homem sem qualquer experiência do mundo. Como vimos pela Investigação, e Filão a repete, tal homem "seria totalmente incapaz, a partir meramente de suas ideias, de determinar que tipo de cena o universo deve ser ou dar preferência a um estado ou situação de coisas sobre um outro." (DNR, II, §12) Isto porque para Filão, como para Hume, tudo quanto seja questão de fato é possível de um ponto de vista metafísico; assim, a personagem explica a ignorância de Adão dizendo

que como nada que ele conceba claramente poderia ser estimado impossível ou implicar contradição, toda quimera de sua fantasia poderia estar em pé de igualdade; e tampouco poderia determinar alguma razão justa por que ele adere a uma ideia ou sistema e rejeita outras que são igualmente possíveis. (ibidem)

Por este próprio experimento, ficaria difícil negar o que Filão viria a enunciar: "Apenas a experiência pode lhe apontar a verdadeira causa de um fenômeno." (DNR, II, §13) É perfeitamente concebível, por exemplo, que um mundo ordenado possa surgir do caos, ou que brote como uma planta, ou que nasça da inseminação de mundos-pais - enfim, a priori, como nenhuma hipótese concernente a questões de fato pode ser refutada logicamente, todas elas são igualmente possíveis.

Para que o homem de todo inexperiente concluísse que o princípio de ordem é necessariamente racional, e portanto o mundo, que é ordenado, tem um ordenador racional, ele poderia observar que quando se atiram a esmo metais, madeira e vidro, tudo o que se tem são pedaços dispersos desses materiais; no entanto, 
se a estes se junta uma mente, então, e somente assim, poderá surgir um relógio. Desta experiência seguir-se-ia a conclusão de que "há um princípio de ordem na mente, não na matéria. De efeitos similares inferimos causas similares. $\mathrm{O}$ ajuste de meios a fins é semelhante no universo como numa máquina de engenho humano. As causas, portanto, têm que ser semelhantes." (DNR, II, $§ 14)$

Dois pontos hão de ser ressaltados aqui: o primeiro é que, nessa nova formulação de Filão, "ordem, arranjo ou ajuste de causas finais não é, por si só, nenhuma prova de desígnio, mas apenas na medida em que se tenha experiência de ela proceder deste princípio" (ibidem). Decerto não seria nenhum absurdo pedir a um teísta experimental que assentisse a isso, uma vez que, ao pretender uma analogia, a justifica não puramente pela ordem, mas também pelo fato de a ordem proceder de um ordenador. Ainda assim, ressaltar isto não deixa de diminuir a força do gesto dêitico do deísta: ao invés de dizer "Veja quanta ordem, quanto ajuste!", que é apontar algo de fato sem introduzir uma teoria filosófica, o teísta terá de confessar dizer "Veja quanta ordem, quanto ajuste! Estes dois necessariamente provêm de desígnio racional!", o que já foge à mera paisagem e adentra a teoria filosófica. O segundo ponto é justamente o desaparecimento, nessa tradução humeana, do dêitico no argumento. A analogia não mais se impõe baseada em sentimento: trata-se agora tãosomente duma inferência causal.

E duma inferência causal não tão decisiva quanto a de que o sol nascerá amanhã ou que se soltarmos uma pedra ela cairá. Mesmo reformulada, para Filão a analogia de Cleantes continua tendo falhas graves. Em primeiro lugar, é muito grande a dessemelhança entre os objetos comparados. "Onde quer que te apartes o mínimo da similaridade dos casos," diz Filão, "diminuis proporcionalmente a evidência; e podes por fim ter uma analogia bem fraca, que é confessadamente propensa a erros e 
incerteza" (DNR, II, §7). Ora, é difícil pensar dessemelhança e desproporção maiores do que as que jazem entre a construção duma casa e o surgimento do universo. Se é arriscado inferir a circulação do sangue em homens a partir da da seiva nas plantas (cf. DNR, II, §7), imagine-se o quão mais não o será a inferência da criação inteligente do mundo a partir da duma casa. Além da imensurável desproporção entre os objetos comparados, há de se apontar também a falta de um mínimo rigor científico na comparação, pois cientista algum ousaria transferir uma inferência acerca do funcionamento duma parte para o funcionamento do todo, nem do funcionamento dessa parte já desenvolvida para o seu funcionamento num estado ainda embrionário; não se pode, portanto, ter mantido alguma espécie de rigor científico quando se diz que, porquanto na terra só se vê ordem proveniente de desígnio, em todo o universo ordem provém de desígnio, ou que porquanto a ordem no mundo hodierno provém de desígnio, na origem do mundo ela também só provinha de desígnio. E, sobretudo, há a diferença crucial de termos experiência do surgimento de casas, e, mais especificamente, do fato de ela sempre proceder do desígnio de um ser racional, mas do surgimento de mundos simplesmente não termos experiência alguma. Filão termina então por resumir e criticar a analogia de Cleantes assim:

quererá algum homem contar-me, mantendo o rosto sério, que um universo ordeiro tem que surgir de algum pensamento e arte como o humano porque temos experiência disto? Para asserir este raciocínio seria necessário que tivéssemos a experiência da origem de mundos, e com certeza não é suficiente que tenhamos visto barcos e cidades surgirem de arte e engenho humanos... (DNR, II, §24)

Ao cabo, então, de tão pouco séria, a analogia de Cleantes ao ser dita sem pompas se torna difícil de ser enunciada sem risos. 
Logo após essa refutação decisiva, surge uma oportunidade exemplar para mostrar como é importante pôr na interpretação dos Diálogos a argumentação filosófica em primeiro plano, mesmo que não se queira conceder que se trata duma obra escrita com vistas na censura, lembrando-nos ao menos de que Pânfilo é um narrador parcial.

Trata-se do seguinte: logo após a refutação da inferência analógica na Parte II, no começo da Parte III Cleantes tenta convencer Dêmeas da correção de sua própria posição refutando Filão "por ilustrações e exemplos, ao invés de argumentos sérios e filosofia." (DNR, III, §1) São duas as ilustrações e exemplos que dão oportunidade a Cleantes de inadvertidamente concordar com a acusação Filão ao dizer não serem sérias nem filosofia: a de uma voz vinda do céu e a de uma biblioteca vegetativa. Se por acaso víssemos tal exótica biblioteca, com volumes da Eneida e da Ilíada se reproduzindo espontaneamente, quando os lêssemos concluiríamos que foram sim escritos, e por um autor inteligente. Afinal, a anatomia dos animais, tão sofisticada, ofereceria muito mais mostras de desígnio do que os livros da nossa biblioteca fictícia, e portanto haveria de ser criação dum ser inteligente. No outro exemplo, Cleantes nos manda supor "que uma voz articulada foi ouvida nas nuvens, muito mais alta e melodiosa do que qualquer arte humana possa alcançar; [...] que esta voz se estendeu no mesmo instante por todas as nações e falou a cada uma em sua língua e dialeto" (DNR, III, §2), e que ademais comunicara aos homens belíssimas e sapientíssimas palavras. Como ousaríamos negar que tal voz procederia duma inteligência superior? Eis as objeções que Cleantes acha que Filão faria contra os seus exemplos, e que seriam tão válidas quanto as feitas contra o argumento do desígnio:

Acaso não poderias dizer que todas as conclusões concernentes a fatos são fundadas em experiência [...], mas que essa voz extraordinária, por sua altura, extensão e flexibilidade a todas 
as linguagens, sustenta uma analogia tão pequena com qualquer voz humana que não temos razão para supor uma analogia entre suas causas? E, consequentemente, que uma fala racional [...] procedeu não sabias donde, talvez dum assobio acidental dos ventos; não dalguma razão ou inteligência divina? (DNR, III, §3)

Ora, se bem tivermos entendido a crítica de Filão, sabemos que ele não poderia levantar tais objeções a esses exemplos. Acontece que já tivemos experiência do surgimento de livros e de fala articulada, e sabemos que estes procedem única e exclusivamente de uma mente racional; ou, nas palavras de Hume, sabemos que “ouvir uma voz articulada e um discurso racional no escuro assegura-nos da presença de alguma pessoa. Por quê? Porque tais são os efeitos da constituição da fábrica e do ser humano, e estão intimamente conectados com ele." (EHU, IV, i, §4) Na certa, portanto, seríamos forçados a admitir que um potentíssimo ser algo antropomórfico produzira tão espantosos fenômenos - mas tão-somente porque temos experiência da produção de livros e discursos. Como, ao contrário, não temos experiência do surgimento de mundos, então a refutação de Filão segue intacta.

No entanto, ele não respondera a esses exemplos desprovidos de seriedade e filosofia; ao invés disso, fora interrompido por Dêmeas, que aceitara essa defesa de Cleantes. O narrador descreve o momento assim: "Aqui pude observar, Hermipo, que FILÃo estava um pouco embaraçado e confuso: mas enquanto ele hesitava em proferir uma resposta, para sua sorte DÊMEAS interrompeu o discurso e livrou-lhe a cara." (DNR, III, §10) Mas já sabemos que o aparato crítico de Filão dá conta perfeitamente dessas objeções; a observação de Pânfilo é apenas a de um discípulo imaturo de Cleantes. A grande vantagem da interrupção pela parte de Dêmeas cremos ser a de levar Filão esgotar a teologia natural, impedindo que, com apenas uma refutação decisiva, 
os Diálogos sobre a religião natural tenham só duas partes e então se furte a uma crítica exaustiva.

2) Um desencontro teórico-argumentativo

A impossibilidade de fazer uma inferência causal sem hábito nem experiência de conjunção entre eventos desaparece do texto, e nada há que Cleantes diga para refutá-la. Filão, ainda assim, ressuscita o elemento dêitico do argumento e tratará de mostrar como tal raciocínio é frágil mesmo que se conceda essa colher de chá. Ele agora atacará o argumento de Cleantes insistindo na sua arbitrariedade.

Como a questão de qual seja o princípio originador do mundo é uma questão de fato e portanto não é possível determiná-la a priori, então não há por que eleger a razão como tal princípio; assim, não há o que nos impeça de afirmar a seguinte proposição: “Um mundo mental ou universo de ideias requer uma causa tanto quanto um mundo material ou universo de objetos; e, se similar em seu arranjo, tem que requerer uma causa similar." (DNR, IV, §7) No que diz respeito à fundamentação empírica ou à falta dela, esta proposição hipotética de Filão estará perfeitamente em pé de igualdade com a que é pressuposta por Cleantes, a de que um mundo mental ou universo de ideias não requer uma causa para sua origem.

Ora, as causas do pensamento são das mais misteriosas: os duma pessoa se deixam alterar por "uma diferença de idade, da disposição do seu corpo, de clima, de comida, de companhia, de livros, de paixões" (DNR, IV, §8). Como é, então, legítimo perguntar pelas causas do pensamento, asserir uma deidade pensante deixa de ser explicativo: se à pergunta de donde venha o mundo material respondermos "do mundo mental", permaneceremos abertos a uma nova pergunta, a de donde venha este. Assim, será possível um progresso in infinitum: "Mas se pararmos e não formos mais longe - para que ir mais longe? Por que não 
parar no mundo material?" (DNR, IV, §9) Noutras palavras, se não pararmos aqui neste mundo, poderemos perguntar também pela causa da deidade que usamos para explicá-lo. A resposta de Cleantes a isto não é exatamente filosófica: "perguntas-me qual é a causa dessa causa [i. e., da deidade]? Eu não sei, eu não ligo, isso não me preocupa. Eu encontrei uma Deidade e aqui paro minha investigação." (DNR, IV, §13)

Frente à irredutibilidade de Cleantes, Filão buscará outra vez novo expediente: agora se valerá do antropomorfismo que é forçosamente abraçado pelo argumento do desígnio ao dizer que o mundo fora engendrado racionalmente por uma deidade tal qual máquinas por homens. O grande problema é que Cleantes diz muito mais da divindade do que que ela seja racional; ela será também para ele única, infinita, incorpórea, perfeita e benevolente. Salvo esta última, nenhuma das outras características é compartilhada por seres humanos.

Filão seguirá com sua tradução para o argumento do desígnio, i. e., continuará a tratá-lo não como uma questão apenas de sentimento, mas como uma inferência causal. Assim, necessária à tese de Cleantes é a proposição pretensamente experimental de que "Efeitos semelhantes provam causas semelhantes" (DNR, $\mathrm{V}, \S 1$ ): o mundo se assemelha a uma casa, e como a causa desta é desígnio racional, então a causa do mundo é desígnio racional também. Assim, terá de ser

certo que, quanto mais parecidos são os efeitos que se veem e mais parecidas as causas que se inferem, mais forte é o argumento. Todo desvio de cada lado diminui a probabilidade e torna o experimento menos conclusivo. Não podes[, diz Filão ao teísta,] duvidar deste princípio nem rejeitar suas consequências. (ibidem)

As consequências serão as de não se poderem dar tantos atributos à divindade quanto se pretendem, ou, pior ainda, dar atri- 
butos opostos. Em primeiro lugar, uma vez que o efeito é, até onde se saiba, finito, então não haveria meios de afirmar a infinitude da causa, i.e., do criador. Também não haveria meios de provar que Deus é perfeito, pois, como somos completamente ignorantes de outros mundos por não termos experiência deles, não podemos de modo algum julgar sua perfeição - e assim, não temos como transmiti-la à sua causa. Nós, humanos, dizermos que o mundo é perfeito, é como "um camponês, se a ENEIDA fosse lida para ele, dizer que este poema é absolutamente impecável ou atribuir-lhe o posto adequado entre as produções do espírito humano" (DNR, V, §6) mesmo sem ter tido contato com outros poemas. Carecemos de experiência e, por conseguinte, de parâmetros para tal.

O caso do atributo da unidade é mais grave: vemos sempre que, quando têm uma grande empresa, os homens se aliam - na construção de barcos e casas, mesmo, sempre são vários operários (às vezes até obtusos) que seguem um modelo que foi aperfeiçoado por eras e eras. Para fazermos uma analogia mais forte, teríamos de dizer que há várias divindades que se aliam na construção deste mundo, que a arte de construir mundos vem se aperfeiçoando por eras e mesmo que ela é executada por deuses obtusos incapazes de sozinhos arquitetarem o mundo. E porquanto não temos como determinar que este mundo é perfeito ou compará-lo a outros, é bem possível que seja um mundo-rascunho, ou um mundo feito por uma divindade infantil inexperiente, ou por outra senil e decrépita. "E por que não tornar-se um antropomorfista perfeito? Por que não asserir que a Deidade ou as Deidades são corpóreas e têm olhos, um nariz, boca, orelhas, etc.?" (DNR, V, §11) Como aqui nos valemos apenas duma analogia - e duma que não foge ao desígnio ou à ideia dum princípio racional de ordem - que recursos terá o teísta para rechaçar teologias que afirmem tais heresias? 
Assim, há um desencontro duplo entre o argumento que com que se quer provar a tese e a tese a ser fundamentada pelo o argumento: a tese de que Deus é uno, imortal e onisciente não se segue da analogia com o desígnio racional humano, ao mesmo tempo em que da premissa de que há uma semelhança entre o engenho humano e o divino também se inferem teologias completamente diversas das religiosas existentes.

3) A analogia teísta não é a única arrebatadora

Já fora estabelecido que não há como, fundamentados na experiência, darmos preferência à razão como princípio de ordem do mundo em detrimento da geração animal. Como o cerne do argumento do desígnio é a semelhança, então devemos antes pender para esta última, pois

se examinarmos o universo, ele tem, até onde o conheçamos, uma grande semelhança com um corpo animal organizado, e parece movido por um princípio semelhante a vida e movimento. [...] O mundo, portanto, infiro eu, é um animal e a Deidade é a ALMA do mundo, movendo-o e sendo movida por ele. (DNR, VI, §3)

Eis, então, mais uma teologia esdrúxula formulada por Filão.

Ora, é fato histórico que certas teologias inventadas por Filão não só sejam críveis como tenham sido bem comumente acreditadas: por certo, todos temos conhecimento de que, "diferentemente do Gênesis bíblico, o modelo de Hesíodo para o vir a ser do cosmos não é o da criação proposital por um Criador designador, mas, ao invés disso, segue o modelo de procriação duma família humana." ${ }^{109}$ Se o parâmetro for a passibilidade de crença, a inferência de um deus adequado à religião cristã não tem qualquer privilégio filosófico sobre a dos numes adequados às pagãs.

109 CLAY, Hesiod's Cosmos, p. 14. 
Hume conhecia teologias pagãs - menciona a de Hesíodo por sua plenitude de divindades e por elas advirem de geração animal (cf. DNR, VI, §13; VII, §15). Mesmo que não o fizesse, mesmo que não as conhecêssemos nem nós nem ele, ainda assim Hume estranharia a nossa falta de estudo caso insistíssemos em ser teístas e defender o privilégio da crença numa origem racional para o mundo - privilégio que, porquanto pretenso inerente à humanidade, deveria se mostrar constante ao longo da história. $\mathrm{Na}$ verdade, não podemos deixar de reparar no tom acusatório de Filão ao dizer: "Tens estudo demais, Cleantes, para te surpreenderes com esta opinião que, tu o sabes, foi sustentada por quase todos os teístas da antiguidade e prevalece ao máximo em seus discursos e raciocínios." (DNR, VI, §4) A opinião referida é aquela de que o mundo é um animal e a divindade é sua alma. O tom é eminentemente acusatório quando nos lembramos de onde a vimos antes: no De natura deorum (I, 37), como sendo da esdrúxula autoria de um estoico chamado justamente Cleantes!

Noutras palavras, é nada menos que indefensável o privilégio da crença num criador racional afirmado pelo teísmo ao chamá-la de natural ao homem. Os fatos e a história - inclusive a história da filosofia - mostram que tal privilégio inexiste, e devem ser considerados pelos estudiosos (inclusive da filosofia de Hume) antes de saírem por aí apontando características ínsitas da natureza humana.

\section{4) O pendor das probabilidades}

Uma crítica repetitiva ao longo dos Diálogos é, como vemos, a arbitrariedade: podem-se pelo mesmo raciocínio do teísmo de Cleantes inferir diversas teologias que não a pretendida por ele; elas devem ter uma espécie de igualdade teórica que não nos permita, com fundamentos filosóficos, escolher uma e preterir as demais. No entanto, Filão vai além disso ao trazer à baila o balanço de probabilidades para colocar a tese teísta em desvan- 
tagem quando comparada a outras: qualquer uma que atribuir vida e corpo à divindade (como faziam os pagãos) e outra a ser inventada pelo próprio Filão.

Os pagãos, como sabemos, viam na geração animal o princípio de ordem do mundo. Primeiro, Filão dirá o seguinte a Cleantes:

Se o universo sustenta uma semelhança maior com os corpos animais e vegetais do que com os trabalhos de arte humana, é mais provável que sua causa se assemelhe mais à dos primeiros do que às dos segundos, e sua origem deve ser atribuída antes à geração ou à vegetação do que à razão ou ao desígnio. Tua conclusão, mesmo de acordo com teus próprios princípios, é portanto frouxa e defeituosa. (DNR, VII, §1, grifo nosso)

Como o argumento do desígnio se sustenta pela semelhança entre os efeitos para inferir uma semelhança nas causas, quanto mais semelhantes forem os efeitos, mais provável terá de ser a inferência da causa. Ora, se é mais fácil apontar semelhança entre seres vivos e o mundo do que entre este e relógios, e se a origem dos primeiros é geração ou vegetação e a destes últimos é razão, então será mais provável a inferência de um princípio de geração ou vegetação. Será mais provável, pois, um sistema de teologia que se baseie num destes dois princípios do que um que se baseie em desígnio inteligente e racional. Este mundo poderia ser explicado pela cópula de mundos pais ou pela floração doutro mundo, e não podemos perguntar donde vêm os mundos pais com menos fundamento do que podemos perguntar donde vem o designador. E tampouco podemos sem petição de princípio estabelecer que o mundo planta ou os mundos animais que tiverem dado origem a este têm de ter sido feitos pelo desígnio de um ser inteligente - do mesmo modo, poderíamos sempre dizer que o Criador precisa ter tido pais. 
E eis agora mais um golpe fatal contra as probabilidades do teísmo experimental: para advogar por estas hipóteses, Filão pode dizer que tem "pelo menos uma tênue sombra de experiência, o que é o mais extremo que se pode alcançar no presente assunto: Observa-se que a razão, em inumeráveis exemplos, surge do princípio de geração, e que nunca surge de qualquer outro princípio." (DNR, VII, §15) Tão fundamental para a retórica newtoniana do teísmo experimental, é justamente a experiência que diminui muito a probabilidade da doutrina. É que temos a experiência invariável de ver a razão surgir da geração animal, mas nem uma sequer do contrário, i.e., de a razão engendrar geração. Inferência analógica por inferência analógica, teremos de reconhecer a dos pagãos como mais provável porque eles têm uma experiência que os corrobore, ao contrário dos teístas. Se "Hesíodo e todos os mitólogos antigos foram tão arrebatados por esta analogia que universalmente explicaram a origem da natureza a partir dum nascimento animal e cópula" (DNR, VII, §16) e a experiência favorece mais esta analogia, por que não devemos dizer que os pagãos estavam melhor fundamentados filosoficamente? $\mathrm{O}$ argumento da tendência natural dos humanos de assentir ao argumento do desígnio tampouco pode ser evocado aqui: os mitólogos também foram arrebatados por uma analogia que lhes pareceu natural e que foi acreditada por seus contemporâneos.

Decisivo, o próximo golpe contra a probabilidade da tese teísta será a formulação duma hipótese que explica a ordem no mundo com o menor número de causas. Trata-se de um modelo que chamamos hoje (apesar de pré-darwiniana) de seleção natural ${ }^{110}$ :

110 Sigo João Paulo Monteiro (cf. "Causalidade e Seleção natural" em Hume e a Epistemologia) ao dar este nome àquilo que Hume chama de hipótese epicurista. Não é exato seguir o filósofo, pois a hipótese de Lucrécio, o epicurista, é muito mais pormenorizada do que a de Hume e tem as significativas diferenças de a matéria ser infinita para um e finita para outro, e por corpos eternos serem impossíveis para um mas não para o outro. Por outro lado, "seleção 
ao invés de supor algum princípio de ordem exterior à matéria, como a razão e a geração, basta supor um que lhe seja intrínseco. Antes de formulá-la explicitamente, Filão já a introduz na Parte VI, quando Cleantes defende a juventude do mundo se valendo do fato de o homem ter transplantado seres vivos dos seus locais originários para outros que lhes eram muito propícios; segundo o teísta, não seria possível que o mundo fosse eterno e o homem nunca tivesse levado, p. ex., a framboesa da Ásia para a Europa. Só convulsões naturais poderiam destruir as alterações humanas na natureza, e estas últimas devem provar que o mundo é jovem (cf. DNR,VI, §8-11). O problema é que não há por que garantir que convulsões naturais não aconteçam; ao contrário, diz Filão, “é possível remontar a provas fortes e quase incontestáveis sobre toda a terra de que cada parte deste globo permaneceu por muitas eras inteiramente coberta por água" (DNR, VI, §12), de modo que se observa sim que a matéria passa por grandes revoluções. Então, sem haver provas em contrário, o mundo pode, sim, ser suposto eterno; e, valendo-se disto, Filão lança disfarçadamente uma hipótese segundo a qual a ordem inere à matéria:

mesmo que a ordem fosse suposta como inseparável da matéria e inerente a esta, ainda assim a matéria pode ser suscetível a muitas e grandes revoluções através dos períodos infindáveis de duração eterna. As mudanças incessantes, às quais cada parte sua está sujeita, parecem anunciar algumas tais transformações gerais; embora ao mesmo seja observável que todas as

natural" é frequentemente atrelada a Darwin. Parece-me contudo defensável a escolha deste termo se cuidarmos em reservar "evolução das espécies" para o darwinismo, sendo por outro lado interessante historiograficamente manter as hipóteses epicurista, humeana e darwinista sob um mesmo espectro: todas elas tiram a causa externa e explicam a ordem de maneira imanente. Digo "historiograficamente" tanto por no passado o epicurismo ter desempenhado o papel de adversário do finalismo desempenhado hoje pelo darwinismo com assemelhadas implicações teológicas, quanto para afastarmos a superstição atual de que as grandes ideias recentes são de todo originais. 
mudanças e corrupções das quais nunca tivemos experiência sejam apenas passagens de um estado de ordem para outro, e tampouco possa a matéria permanecer para sempre em deformidade e confusão totais. (ibidem)

Ordem e caos podem coexistir na matéria (e por conseguinte no mundo) desde que a primeira nos seja oculta e o segundo nos seja aparente. A ordem no mundo será talvez advinda dalgum movimento necessário à matéria, e causará pasmaceira ao teísta do mesmo modo que poderia causar-lhe, se não soubesse matemática, o fato de que "os produtos de 9 compõem sempre ou 9 ou algum produto inferior de 9, se juntares todos os caracteres dos quais quaisquer desses produtos são compostos." (DNR, IX, §10) Aqui se trata do resultado de uma necessidade intrínseca à matemática, e não devemos perguntar quem foi que engendrou os múltiplos de nove de modo que seus algarismos somados dessem sempre nove ou outros múltiplos de nove.

A hipótese de seleção natural, pois, é a seguinte: há uma quantidade finita de matéria, uma duração infinita de tempo, e a matéria se move eternamente segundo uma ordem que, embora desconhecida por nós, lhe é inerente. Que a matéria esteja sempre em movimento é perfeitamente observável no mundo, e supor que alguém a pôs em movimento é "hipótese acompanhada de nenhuma vantagem" (DNR, VIII,§4) porque, com quanto menos causas explicarmos um fenômeno, melhor. A consequência dessa junção de infinitude do tempo e finitude da matéria que se move sempre é que é bem possível que o mundo se forme tal como está e seja destruído várias vezes ao longo da eternidade, pois "um número finito de partículas é suscetível apenas a transposições finitas; e deve acontecer, numa duração eterna, que cada ordem ou posição possíveis devam ser tentadas num número infinito de vezes." (DNR, VIII, §2)

Temos, pois, uma explicação para a origem do mundo que dispensa fatores que lhe sejam externos, e se não for menos ex- 
plicativa do que as de que dispomos, deve ser preferida por conta da economia de causas. Afinal, devemos estar bem lembrados de que o método newtoniano para a filosofia natural fora trazido por Hume também para a filosofia moral e portanto não devemos admitir mais causas do que o necessário.

A objeção que um teísta talvez levantasse é a de que a matéria sem designador não alcançaria esse ajuste de meios a fins, essa ordem perfeita da natureza. Aqui a temos descartada por Filão, mostrando como o mundo ordeiro poderia surgir sem desígnio e em conformidade com sua hipótese:

O movimento contínuo da matéria, [...] em transposições menos do que infinitas, deve produzir esta economia ou ordem, e por sua natureza mesmo essa ordem, quando uma vez estabelecida, se suporta por muitas eras, se não pela eternidade. Mas onde quer que a matéria seja equilibrada, arranjada e ajustada assim de modo a continuar em movimento e ainda preservar constância em suas formas, sua situação tem necessariamente que ter a mesmíssima aparência de arte e engenho que ora observamos. (DNR, VIII, §6)

Assim, a própria matéria em suas revoluções infinitas terminaria por, em algum momento, formar essa ordem que vemos no mundo, que é uma ordem que tende a manter-se por si só até que, dalguma maneira rompendo-se, termina por degenerar e a tornar-se outra forma. É o que vemos nos animais, que se tiverem defeitos de nascença não conseguem sobreviver, e que quando têm roto algo necessário ao seu bom funcionamento adoecem ou morrem. De certa forma, a ordem que vemos no mundo é necessária: se as coisas não forem internamente bem ajustadas, elas perecem até mesmo antes de virem a ser. Eis, por fim, o golpe fatal desferido contra a inferência teísta: 
É vão [...] insistir nos usos das partes em animais e vegetais, e no seu curioso ajuste mútuo. Eu gostaria de saber como um animal poderia subsistir se suas partes não fossem bem ajustadas. [...] Acontece, de fato, que as partes do mundo são tão bem ajustadas [...]. E se não fosse assim, poderia o mundo subsistir? Ele não teria que se dissolver tanto quanto um animal [...]? (DNR, VIII, §9 - grifo nosso)

Trata-se quase de lógica: só é aquilo que pode ser. Dizemos "quase" porque aí entra em jogo também a experiência que temos do mundo e da ordem da natureza. Num mundo essencialmente desordenado que demandasse a causa externa de Cleantes - o designador necessário para a ordem -, haveríamos de ter alguma experiência de corpos anencéfalos e acardíacos gozando de vida longa apesar da necessidade dos órgãos faltosos, casas erguidas sem qualquer fundamento apesar da lei da gravidade... mas em tal mundo deveríamos inferir a total desordem e negar o designador racional. Filão pode, então, selecionar esta hipótese como sendo "uma nova espécie de cosmogonia que não é absolutamente absurda e improvável" (DNR, VIII, §8), ao contrário daquelas com as quais ele vem lidando ao longo da conversa com seus colegas. Ao cabo, "se um 'princípio de eliminação dos inaptos' é suficiente para explicar a adaptação observável dos seres vivos, bem como o mútuo ajuste de seus órgãos, qualquer recurso a uma causa divina será equivalente a uma multiplicação desnecessária de causas." 111

5) Misticismo e ateísmo, quase equivalentes

“Céticos numa era, dogmáticos noutra, qualquer que seja o sistema que melhor sirva ao propósito desses cavalheiros reverendos de dar-lhes uma ascendência sobre a humanidade, têm certeza de fazê-lo o seu sistema favorito e estabelecer o preceito."

111 MONTEIRO, op. cit., p. 117. 
(DNR, I, §19) É assim, política e não filosoficamente, que Filão explica a modéstia intelectual de Dêmeas, que se humilha perante a Divindade incognoscível. Ademais, notemos que é possível - porquanto foi praxe - ser um cético em defesa da fé religiosa.

Para Filão, então, as escolhas filosóficas dos membros do clero são tomadas com vistas em influência política. Conforme nos conta, antigamente, em eras mais ignorantes e com pouco intercâmbio cultural, dava-se quase tanto crédito ao que se aprendia pela cultura da sociedade em que se vivia quanto ao que se aprendia pelos sentidos. Assim, como "os padres perceberam que ateísmo, deísmo ou heresia de qualquer tipo poderiam proceder apenas do questionamento presunçoso de opiniões recebidas e duma crença de que a razão humana era igual a tudo" (ibidem), a saída para enfraquecer os questionamentos à fé era enfraquecer a razão. Ora, fazê-lo nada mais é do que adotar ceticismo; é dizer que nada podemos saber por conta própria e, portanto, só nos resta receber do Altíssimo - ele, sim, onisciente - o pouco de que precisamos saber, que é como ser salvo.

Daí vem a extrema humildade intelectual de Dêmeas: em teologia, somos incapazes de conhecer qualquer característica divina; em questões morais, deixamos para o sacerdote a recomendação dos princípios a serem seguidos; na vida comum, temos de nos conformar com nossa miséria e ansiar pela vida após a morte, que é a que realmente importa.

Com uma coisa Filão concordara: somos incapazes de conhecer qualquer característica divina. Como vimos, Dêmeas repartiu em dois o questionamento acerca de Deus: há o de se ele existe e o de qual seja a sua natureza. Que ele exista, Dêmeas provou logicamente; qual seja a sua natureza, está vedado ao nosso frágil entendimento. É, pois, natural que se alie a Filão para "provar o adorável mistério da natureza divina" (DNR, II, §10).

Precisamos, no entanto, revisar o que Dêmeas prova: que há "um ser necessariamente existente, que carrega em si mesmo a 
RAZÃo de sua existência e que não se pode supor que não exista sem uma contradição explícita" (DNR, IX, §3), i.e., há uma causa prima de que tudo o mais que existe seja efeito. É tão-somente causa, sem qualquer atributo determinado, o que Dêmeas chama de Deus. Interessa notar que, sem atribuir certeza lógica ao seu raciocínio, Filão diz algo muito parecido: "Nada existe sem uma causa, e à causa original deste universo (qualquer que seja ela) chamamos Deus e piamente lhe atribuímos todas as espécies de perfeição." (DNR, II, §3 - grifo nosso). Mas não nos apressemos em concluir aqui que há segundo Dêmeas alguma determinação de características da deidade, pois lhe atribuímos "sabedoria, pensamento, desígnio, conhecimento" apenas porque "essas palavras são honoráveis entre homens e não temos outra língua ou outras concepções pelas quais possamos expressar nossa adoração por ele" (ibidem); não porque Deus tenha sabedoria, pensamento, desígnio ou conhecimento, pois estes são atributos humanos. Uma vez que temos de louvá-lo, que seja com as únicas palavras laudatórias de que dispomos, e registre-se a nossa boa intenção.

Com mais ou menos o mesmo raciocínio, as ênfases dadas por Filão e por Dêmeas em muito diferem no ser postulado. Enquanto o metafísico diz que "há um tal ser [necessariamente existente], isto é, há uma Deidade" (DNR, IX, §3 - grifo nosso), dando por óbvia a identificação entre causa prima e Deidade, o acadêmico diz apenas que tal causa é chamada de Deus, e qualquer que seja ela. Se hoje estivermos satisfeitos em dizer que a "causa original deste universo" é o Big Bang, então é o Big Bang que chamamos de Deus.

Por certo, dificilmente conseguimos imaginar alguém rezando para o Big Bang ou adorando-o, e a elaboração de teorias físicas não acarreta a inauguração de religiões votadas a causas cósmicas recém postuladas ou descobertas. E é certo também que este 
não é o único ponto a estranhar na concordância de Filão com Dêmeas.

O mais evidente, para qualquer leitor mesmo introdutório ou superficial de Hume, é que a personagem que pretendamos humeana jamais poderá assentir à demonstração da existência divina. No Tratado, Hume a tinha por simples questão de fato:

É evidente que todos os raciocínios feitos a partir de causas ou efeitos terminam em conclusões a respeito de questões de fato, isto é, a respeito da existência de objetos ou suas qualidades. É também evidente que a ideia de existência não é nada diferente da ideia de um objeto. Quando, após ter[mos] simplesmente concebido alguma coisa, nós em seguida a concebemos como existente, na realidade não acrescentamos nada a nossa primeira ideia, e tampouco a alteramos. Assim, quando afirmamos que Deus existe, simplesmente formamos a ideia desse ser, tal como ele é representado; a existência que a ele atribuímos não é concebida mediante uma ideia particular que juntaríamos à ideia de suas outras qualidades (THN, I, iii, 7, §2)

Ao mesmo tempo em que explica o que seja a crença - uma alteração no modo de conceber uma ideia, como dirá em seguida -, Hume já introduz no exemplo, como que mal disfarçada, uma crítica à metafísica que morria à sua época. Como Hume já tinha estabelecido que questão de fato não se demonstra (cf. THN, I, iii, 1), ao colocar a existência de Deus como tal, nada mais precisa ser dito para que descartemos a prova a priori. Na Investigação sobre o entendimento humano, vimos também o critério de ser demonstrável ou não para distinguirmos relações de ideia de questões de fato.

Quem rememora essa crítica humeana é Cleantes: "há uma absurdidade evidente", diz ele, "em pretender demonstrar uma questão de fato ou prová-la por meio de argumento a priori. Nada é demonstrável, a menos que o contrário implique uma contradição. O que quer que concebamos como existente podemos con- 
ceber também como inexistente." (DNR, IX, §5) O ponto fraco que este argumento de Cleantes e a postura de Hume no Tratado têm em comum é que elas supõem que o fiel tenha uma ideia de Deus, algo a que de modo algum Dêmeas assentiria (lembremos que ideias, ainda por cima, são carregadas de experiência!). Mesmo assim, não temos como introduzir a prova a priori na filosofia de Hume; afinal, dizer "x existe" é enunciar um fato, e fatos não se demonstram. Para isto, não precisamos falar da ideia que o fiel forma de Deus. Antes de passarmos à continuidade da crítica a esta prova, vejamos o que mais Cleantes tem a dizer sobre ela. Seu outro argumento para derrubá-la é justamente o de ela postular mais causas do que o necessário! Ele pergunta: "Por que não pode o universo material ser o Ser necessariamente existente, de acordo com essa pretensa explicação de necessidade?" (DNR, IX, §7) Ora, como víamos, esta é uma objeção levantada por Filão ao sistema de Cleantes: Por que não parar num mundo material, ao invés de acrescentar um mundo mental? (E justo um mundo mental que não é tão explicativo assim? E por que fazê-lo quando há a experiência de a mente advir de geração animal, mas não o contrário?) Naturalmente, Filão não levanta objeção alguma aos argumentos de Cleantes - apenas complementa seu raciocínio mostrando que "é tão perigoso introduzir esta ideia de necessidade à presente questão" (DNR, IX, §10) através daquele exemplo algébrico dos múltiplos de nove. Introduzi-la ao discutirmos a origem do mundo faz com que limemos o número de causas se a atribuirmos ao próprio objeto a ser explicado, i.e., o mundo. Eis que, mesmo valendo-se de argumentos humeanos para atacar um espécime escolástico, Cleantes se deixa atacar por Filão com seu princípio de economia - que é certamente abraçado pelo próprio Hume.

Cleantes tem outro grande momento humeano ao atacar Dêmeas. Enquanto este dera àquele o epíteto pejorativo de antropomorfista, é-lhe devolvido o de místico. Como Dêmeas faz 
questão de não atribuir qualidade alguma a Deus, Cleantes lhe pergunta: "O nome, sem qualquer significado, é dotado de importância tão poderosa? Ou como vós, Místicos, que sustentais a incompreensibilidade absoluta da Deidade, diferis dos céticos ou ateus, que afirmam que a causa do Todo é desconhecida e ininteligível?" (DNR, IV, §1) O que Cleantes nos mostra aqui é que, ao cabo, o ceticismo de Dêmeas é muito mais extenso do que o pretendido. Quando ele tolhe os poderes da razão, não lhe é mais possível postular nada que ela, de tão frágil, possa compreender. $\mathrm{O}$ argumento de Dêmeas, embora a priori, inadvertidamente cruza o espaço da lógica e adentra o factual. Assim, terá de responder às mesmas perguntas que qualquer pensador afeito ao experimental faça. Deus, para Dêmeas, é a primeira causa de tudo - e tem que ser, pois é apenas enquanto tal que ele prova a sua existência. $\mathrm{O}$ que mais seja Deus, Dêmeas não se atreve a determinar. Ora, Cleantes, Filão, Hume, Newton, Galileu e nós mesmos podemos todos fazer longe da igreja a pergunta de qual seja a causa de tudo. Se perguntarmos a um cético, ele dirá "não sei"; se perguntarmos a Dêmeas, que nada sabe de Deus senão o nome que lhe dá, a resposta há de ser a mesma que a do cético! Cleantes ressalta também que é uma escolha, uma arbitrariedade chamar a causa de Deus: "Sua [i.e., dos ateus e céticos] consciência deve ser de fato bem escrupulosa, se se recusarem a chamar a causa universal, desconhecida, de Deus ou Deidade e a outorgar-lhe tantos elogios sublimes e epítetos sem significado quanto quiseres lhes pedir." (ibidem)

Aqui, pelo menos, Cleantes não argumenta contra si próprio, pois dentre os três professores ele é o único que diz saber qual é a causa do mundo e conhecer algo da natureza divina. Por certo, a acusação de ceticismo feita a Dêmeas respinga em Filão - mas sabemos já que para ele ceticismo é objeto de sua profissão, e não acusação; aliás, podemos até adivinhar que ele se recuse a outorgar elogios sublimes à causa universal. Antes de passarmos 
adiante, atentemos que Dêmeas tivera ótimas oportunidades para romper com Filão antes da Parte XI. Este até mesmo concordara com Cleantes em descartar a prova de Dêmeas da existência divina!

6) Teístas felizes e metafísicos melancólicos

Se já não nos tivesse sido respondido desde o começo, poderíamos perguntar por que Dêmeas investe em expediente tão estranho como o de entrar numa disputa para defender que a causa pela qual se pergunta tem um determinado nome, mas sem dar-lhe significado algum. Fora-nos já respondido por Filão: é que ele, como cavalheiro reverendo, tem em vista influência política sobre a humanidade. Como, à época em que florescia o discurso de Dêmeas, era uma razão muito creditada a que atentava contra a fé, coube aos sacerdotes abraçar uma espécie de ceticismo e fazer "declamações contra a razão, contra os sentidos e contra qualquer princípio derivado meramente de pesquisas e investigações humanas" (DNR, I, §17). Assim, nada sabendo e nada tendo condições de questionar, a humanidade nada tem a fazer senão seguir aqueles poucos instruídos pelo Altíssimo, aos quais pleno poder termina por ser assegurado.

"Céticos numa era, dogmáticos noutra", dizia Filão. Enquanto o ceticismo ficava a cargo de Dêmeas, o dogmatismo ficará para Cleantes. É que este é filho doutras eras, mais modernas. Nelas, as pessoas, "por um comércio aberto com o mundo, aprenderam a comparar os princípios [religiosos] populares de nações e eras diferentes"; não era mais trivial, porque única, crer numa determinada religião. Há de ser estabelecido, então, um meio necessário de afirmar o privilégio da nossa sobre as demais, e para isso a razão passará, ao contrário, a ser inflada pelos teólogos: agora, eles falam "a linguagem dos ESTOICOS, PLATÔNICOS e PERIPATÉTICOS, não aquela dos PIRRÔNICOS e ACADÊMICOS. Se desacreditarmos a razão humana, não temos mais princípio algum para nos levar à 
religião" (DNR, I, §19) Tanto a tese de Dêmeas quanto a de Cleantes se orientam pela finalidade política de estabelecer a crença em suas religiões, e é a este fim que as teorias têm de se ajustar.

O problema é quando os teóricos começam a ter que ajustar os fatos para estabelecer o argumento. Como Dêmeas exorta a extrema modéstia intelectual e admite que o vulgo não crê em Deus por causa de seus raciocínios abstratos, ele explicará assim por que os homens comuns são levados a crer:

cada homem sente, de certo modo, a verdade da religião no seu próprio peito; e por uma consciência de sua fraqueza e miséria, [...] é levado a buscar proteção nesse Ser do qual ele e toda a natureza dependem. Tão ansiosas ou tão tediosas são até mesmo as melhores cenas da vida, que a futurição é ainda o objeto de todas as nossas esperanças e medos. [...] Criaturas desgraçadas que somos! (DNR, X, §1)

O mundo, para Dêmeas, é mau, e a condição da existência humana é miserável. E é isso o que explica a crença numa religião tão voltada para a futurição.

Ora, evidente que Cleantes não pode assentir a isto: sabemos que Deus existe justo porque há sinais da providência neste mundo tão bem engendrado, com estas criaturas tão bem ajustadas de modo a viverem felizes. Filão aqui não deixará de atiçar a discordância entre os dois teólogos, e em meio ao discurso lamurioso de Dêmeas acrescenta mais uma queixa trazendo à baila o mau engendro da natureza que fez os seres vivos de modo a viverem em eterno conflito. E o caso mais exemplar desse mau engendro é justamente o do homem supersticioso e temente a um Deus punitivo, que, tendo em sociedade sobrepujado os inimigos reais, inventa-os mais poderosos para si próprio, criando "os demônios de sua fantasia que [...] arrasam todo o gozo da vida". (DNR, $\mathrm{X}, \S 11)$ Eis que assim vive tal homem: 
Seu prazer, como ele o imagina, torna-se aos seus olhos um crime. Sua comida e repouso lhe causam ressentimento e ofensa. Seu sono e seus sonhos fornecem material para um medo ansioso. E mesmo a morte, seu refúgio de todo outro mal, lhe apresenta apenas o pavor de calamidades infindáveis e inumeráveis. Nem o lobo molesta mais o rebanho tímido do que a superstição o peito de mortais desgraçados. (ibidem)

Não podemos deixar de notar aqui o eco do ensaio escrito na juventude mas também de publicação póstuma, o "Do Suicídio", onde Hume defende a razoabilidade e a licitude de matar-se quando o indivíduo julgar a morte - o termo de todos os males preferível à vida. Só os supersticiosos recusam este remédio e se forçam a viver em sofrimento. Paralelamente, não deixamos de notar também que essa argumentação do "Do Suicídio" se volta sobretudo contra essa retórica religiosa segundo a qual vivemos num vale de lágrimas à espera da única vida boa, a de após a morte: se esta vida é tão ruim assim, melhor é matar-se; se isto é proibido e os gozos são um crime, a superstição tortura o fiel ao tornar sua vida detestável porém obrigatória.

E é neste ponto que Filão insistirá secretamente. Se nos Diálogos Hume vela a sua posição colocando-a na boca duma personagem, e na Seção XI da Investigação sobre o entendimento humano na dum "amigo que aprecia paradoxos céticos" (§1), aqui ele duplica o expediente: é um interlocutor hipotético de Filão quem pergunta pelos devotos melancólicos: "Mas se eles forem realmente tão infelizes quanto pretendem, [...] por que permanecem na vida...?" (DNR, X, §17) Enquanto Filão em seu próprio nome insiste na ínsita miséria humana, seu interlocutor hipotético simplesmente a nega (cf. DNR, X, \$19).

O diálogo de Filão consigo próprio é interrompido por Cleantes insistindo que não sente em si nenhuma melancolia ou consciência da miséria humana, concordando assim com o interlocutor hipotético. No entanto, Filão continuará com sua retórica 
aliada à de Dêmeas; ele insistirá nas consequências do antropomorfismo de Cleantes - afinal, embora não assintamos à miséria da existência humana, pelo menos não podemos negar que haja muitos dos males que Dêmeas lista, tais como peste, guerra e fome. Se abraçarmos o antropomorfismo de Cleantes, "as velhas questões de EPICURO continuam ainda sem resposta. [A deidade] é desejosa de prevenir o mal, mas incapaz? Então é impotente. É capaz, mas não é desejosa? Então é malevolente. É capaz e desejosa ao mesmo tempo? Donde vem então o mal?" (DNR, X, §25) Podemos reformular estas questões quer como um dilema, quer como um trilema, a depender do que quisermos entender por Deus. Se não tivermos nenhuma ideia dele, elas assumirão uma forma de dilema cujas soluções são:

(1) Deus não é bom.

(2) Deus não é onipotente.

Se mantivermos uma concepção antropomórfica, que descreve Deus com essas duas qualidades, temos um trilema ao qual se acrescenta esta solução:

(3) Deus não existe.

Claro está, pois, que Dêmeas enfrenta o dilema e Cleantes o trilema, ambos de Epicuro ressuscitado.

Num passe de teodiceia, Dêmeas consegue desertar:

Este mundo é apenas um ponto em comparação ao universo; esta vida, apenas um momento em comparação à eternidade. Os presentes fenômenos maus, portanto, são retificados noutras regiões e nalgum período de existência futuro. (DNR, X, §29)

Nalgum plano do qual não temos a mais ínfima experiência, as injustiças do presente mundo serão compensadas. Ora, o nosso teísta experimental jamais poderá assentir a esta saída. Após chamá-la de arbitrária, questiona indignado: "Por onde se pode provar qualquer hipótese senão pelos fenômenos aparentes?" (X, §30) Seria exaustivo rememorar aqui as críticas de Filão feitas 
a Cleantes com base nesta cobrança; basta apontar que novamente o teísta, ao atacar Dêmeas, termina por argumentar contra si próprio. No entanto, ele tem consciência do desdobramento que tal cobrança tem no argumento que então desenvolve; ele admite que "o único método de sustentar a benevolência divina [...] é negar absolutamente a miséria e desgraça do homem." (X, §31) E isto não lhe parece de início ser um problema, pois não hesitará em dizer que "a saúde é mais comum que a doença, o prazer que a dor, a felicidade que a miséria. E para cada vexação que encontremos, conseguimos, computando, uma centena de gozos." (ibidem)

Por certo: se apenas pelos fenômenos podemos inferir uma causa, e daí formar nosso sistema teológico, sendo que este mantém a bondade da divindade para com os homens, então os fenômenos tem que ser o da felicidade humana. No entanto, é claro que deve se considerar uma temeridade a afirmação dum cômputo universal de gozos e vexações. Também é claro que Filão não poderia deixar de repreendê-la, e, perante a óbvia falta de medidores de felicidade, ele o faz apenas por uma negação (cf. X, §33). Ainda assim, continuará sendo um problema o porquê de Deus permitir que exista sequer um mal no mundo, e Filão ainda virá a insistir nisto.

De resto, a persistência do teólogo cético em afirmar a infelicidade do mundo e a do teólogo dogmático em afirmar a felicidade do mundo dá a Filão nova oportunidade de refletir sobre o padrismo. Segundo ele, cavalheiros reverendos

sabem como mudar seu estilo junto com os tempos. Antigamente era o tópico teológico mais popular defender que a vida humana era vaidade e miséria e exagerar todos os males e dores que aconteceram aos homens. Mas em anos tardios, teólogos, vemos, começam a desdizer essa posição e manter, embora ainda com alguma hesitação, que há mais bens do que males, mais prazeres do que dores, mesmo nesta vida. Esta variação 
é a mesma (e advinda das mesmas causas) que apontei antes a respeito do ceticismo. (DNR, XI, §20)

Para teólogos, o mundo é mau e o mundo é bom, se isto lhes der ascendência sobre a humanidade. Escolhidos com tão pouco escrúpulo filosófico, não é de admirar que esses raciocínios sejam tão suscetíveis à crítica dum pensador que de fato preze pela sua coesão filosófica.

\section{7) Causa amoral}

Cleantes, então, fica obrigado a enfrentar o seu trilema. A escolha que ele faz é por negar a onipotência a Deus (cf. DNR, XI, $\S 1$ ): esta não agravará tanto o seu sistema porque não convém a um pensador experimental ficar afirmando infinitudes, das quais experiência não é possível, como essa do poder divino. A hipótese que ele lança então para salvar sua teologia é que Deus é benevolente, e se não fez melhor é porque não pôde; de repente, "pode-se então escolher um mal menor a fim de evitar outro maior [...], a benevolência, regulada pela sabedoria e limitada pela necessidade, pode produzir justo um mundo tal como o presente." (DNR, XI, §1)

Uma vez que todo o argumento teísta estabelece um Ser antropomórfico e Filão é humano, nada impede que ele próprio troque de posições com Deus. Se nos mostrassem uma casa bastante incômoda, falaríamos mal do arquiteto mesmo sabendo que ele não é onipotente, pois é uma questão de bom senso projetar de acordo com os recursos de que se dispõe. Para isso, não precisamos nem conhecer o projeto ou saber exatamente como fazer um melhor. Ainda assim, caso se queira contestar isto ${ }^{112}$,

112 Butler mesmo reclama daqueles que "se entregam a especulações vãs e fúteis sobre como o mundo poderia ter sido forjado de modo diferente e, ao imaginarem que as coisas deveriam ter sido dispostas e continuado segundo um modelo melhor do que o que aparece na sua presente disposição e conduta, se baseiam na suposição de que as coisas poderiam ser assim." (Op. cit., p. 26) 
Filão pôde ele próprio apresentar com facilidade quatro circunstâncias que, se alteradas, em muito aumentariam a felicidade dos seres vivos. (Cf. DNR, XI, §6-11)

Os fenômenos, pois, são bons e maus, e é exigido pelo sistema de Cleantes que seja a partir deles que se formem noções da divindade. Assim, Filão lista quatro hipóteses para a moralidade das causas:

que elas são dotadas de bondade perfeita, que elas têm uma malícia perfeita, que elas são opostas e têm tanto bondade quanto malícia e que elas não têm bondade nem malícia. Fenômenos mistos jamais podem provar aqueles dois princípios sem mistura. E a uniformidade e constância de leis gerais parecem se opor ao terceiro. $\mathrm{O}$ quarto, portanto, parece de longe o mais provável. (XI, §15)

Cleantes nem sequer poderia acudir à outra opção respaldada por fenômenos, pois toda a sua analogia visa a fundamentar justo uma divindade única.

É aqui que Dêmeas rompe com Filão. O que ele fizera foi negar aquilo que sua tese estabelecia: o ceticismo pleno acerca das características da divindade ou causa prima. Sendo cético acadêmico, que raciocina sobre fenômenos para formular hipóteses prováveis, o que Filão fizera fora nada menos que afirmar a maior probabilidade duma característica da causa prima do mundo, a saber, a amoralidade.

8) Analogia esvaziada, "Deus" sem significado

Xeque-mate. Enquanto o que Cleantes queria provar é que Deus é bom, poderoso, único, racional e que é uma analogia entre a causa do mundo e a causa de máquinas que nos força a inferir sua existência, Filão ao longo dos Diálogos já desmontou a inferência e excluiu quaisquer características antropomórficas. Não bastassem as negativas, chegou mesmo a colocar duas hipó- 
teses prováveis que contrariam a tese de Cleantes: há movimento e ordem ínsitos na matéria que produzem o mundo e as causas deste são amorais.

O que há a ser salvo dentre os raciocínios de Cleantes? Tãosomente a analogia, e é somente a isto que Filão pode assentir. Eis aqui um trecho famoso em que ele supostamente se converte ao teísmo:

Se toda a teologia natural [...] se resume a uma proposição simples, embora algo ambígua ou ao menos indefinida de que "a causa ou causas de ordem no universo provavelmente sustenta alguma analogia remota com a inteligência humana", se esta proposição não for capaz de extensão, variação ou explicação mais particular, se ela não fornecer nenhuma inferência que afete a vida humana ou possa ser a fonte de qualquer ação ou proibição, e se a analogia, imperfeita como ela é, não puder ser levada para mais longe do que a inteligência humana, nem transferida para as outras qualidades da mente com qualquer aparência de probabilidade - se este realmente for o caso, o que poderá o homem mais inquisitivo, contemplativo e religioso fazer além de dar um assentimento pleno, filosófico à proposição [...]? (DNR, XII, §33)

Ora, havemos de reparar que nenhuma condicional pode aceita por qualquer teísta experimental! (Aliás, quando Filão diz "causa ou causas", vemos que ele já exclui mesmo a determinação do monoteísmo!) As condições que Filão coloca para que se assinta ao teísmo são nada menos que ele se esvazie por completo, restando somente uma analogia frouxa e filosoficamente estéril. E quando ele ameaça o teísmo com a perda de qualquer aparência de probabilidade caso não se confine àquela proposição que afirma meramente uma analogia, não há como crermos que ele nega ou reputa cavilações todas as objeções que levantara durante toda a conversa. Senão, por que mais o teísta estaria impossibilitado de extrapolar a analogia? 
Terá, então, tal conversão algum significado? Terá, antes disso, o conceito concedido de Deus algum significado? E o da religião verdadeira? Lembremos aquela acusação feita por Cleantes a Dêmeas, a de que ele é místico por falar sem significado. Era de fato uma acusação para Dêmeas, mas para Filão o mesmo se dá com a acusação de ceticismo: não há problema algum dizê-lo ao seu respeito por que ele mesmo assume desconhecer aquilo que possa receber o nome de "Deus". Já na Parte II Filão quer evitar todos esses embaraços afirmando que ele não sabe o que é Deus, e não pode saber porque é cético, i. e., porque "esse assunto jaz mui vastamente além do alcance de [suas] faculdades" (DNR, II, \$24) Quando Filão diz "eu não sei" (ibidem) à pergunta do que seja Deus e alude às suas próprias faculdades, fique claro que não se trata duma incapacidade ou ignorância pessoal, uma vez que o impeditivo são as faculdades humanas e a falta de experiência que os humanos têm do assunto. O problema é que Filão não crê que apenas ele próprio e Dêmeas desconheçam o significado do vocabulário empregado na discussão, mas também Cleantes. Assim como "foi usual entre os Peripatéticos [...], quando a causa dalgum fenômeno era demandada, ter recurso às suas faculdades ou qualidades ocultas e dizer, por exemplo, que o pão nutria por sua faculdade nutritiva e o sene purgava por seu purgativo", bem se poderia dar uma resposta similar à ordem dos objetos materiais, podendo excluir-se um criador externo e apenas “dizer que tal é a natureza dos objetos materiais e que eles são todos originariamente possuidores duma faculdade de ordem e proporção." Não que seja um bom expediente, pois "descobriuse que este subterfúgio nada era senão disfarce de ignorância, e que esses filósofos, embora menos ingênuos, na verdade diziam a mesma coisa que os céticos ou o vulgo, que de bom grado confessaram desconhecer a causa desses fenômenos." Acrescentando um criador, o que os teístas fazem para explicar a "causa [que] produz ordem nas ideias do Ser supremo" é apenas dizer que é 
"uma faculdade racional, e que tal é a natureza da Deidade", com desvantagem perante os peripatéticos, que também apontavam nomes vazios mas sem introduzirem causa extra. Em última instância, para o teísta o princípio designador da Deidade faz com que ela designe: ao cabo, trata-se somente dum meio elaborado e nada econômico de "confessarmos nossa ignorância" (DNR, IV, §12) acerca das características da causa do mundo.

Bem mais tarde, já na Parte XII, Filão retoma o problema do significado no andamento da discussão: ele suspeita que "entra algo de disputa de palavras nessa controvérsia, mais do que comumente se imagina." (DNR, XII, §6) É que, segundo ele, por um lado é possível fazer uma analogia entre as relações do mundo com sua causa e os artefatos com as suas, mas é possível insistir também em suas discrepâncias. Para Filão (cf. DNR, XII, §6), podemos então fazer a escolha de, por conta da analogia, chamar a causa de mente ou inteligência. $O$ ponto é que não é apenas o caso que "nenhum homem pode negar as analogias entre os efeitos" (DNR, XII, §6) específicos de que tratamos aqui, mas negar analogias em geral. Afinal, analogias não são fatos dados do mundo: nós não as descobrimos, nos as fazemos. Analogias são inerentemente arbitrárias, e nenhuma teoria positiva acerca dos fatos pode ser cunhada apenas com base nelas sem herdar sua total arbitrariedade.

Ademais, um humeano jamais poderia assentir a essas teologias que nos dão uma vaga noção do que seja Deus - quer a de Dêmeas, que fala tão-somente duma causa de todo desconhecida, quer a de Cleantes, que fala dum ser antropomórfico, bondoso, inteligente, só que sem corpo; que fala, portanto, duma mente que apreende sem sentidos ou de sentidos sem órgãos sensórios. Lembremo-nos de submeter ambos esses deuses ao "microscópio" engendrado nas Investigações sobre o entendimento humano (cf. VII, §4), segundo o qual temos que perguntar pelas impressões das ideias usadas numa discussão. Se ainda quisésse- 
mos nos referir ao arrebatamento especial que deveríamos ter do desígnio da natureza, bem poderíamos tratá-lo como impressão, mas é claro que mesmo assim não poderíamos e nem podemos apontar a impressão que temos do próprio deus. A consequência da regra enunciada na Investigação é clara: se for impossível atribuir uma impressão a uma "suposta ideia" (EHU, II, §9), o que temos é na verdade apenas "um termo filosófico [...] usado sem qualquer significado" (ibidem). De que serve esta conclusão? Com esta, "poderemos razoavelmente ter a esperança de eliminar todas as controvérsias que possam surgir acerca da sua natureza e realidade" (ibidem). Noutras palavras, agora aplicando a conclusão ao presente caso: sabendo que "Deus" é um termo usado sem um significado preciso, podemos eliminar as controvérsias acerca de qual seja a sua natureza e a de se ele é real.

Embora não extraia esta conclusão, Filão lembra o rigor humeano que devemos ter com nossos termos numa discussão:

Todos os homens de razão sã ficam aborrecidos com disputas verbais, que tanto abundam em investigações filosóficas e teológicas; e tem-se visto que o único remédio para este abuso deve surgir de definições claras, da precisão daquelas ideias que tomam lugar em qualquer argumento, e do uso estrito e uniforme daqueles termos que são empregados. (DNR, XII, §7)

Por certo, Deus não é definido ao longo dos Diálogos com mais especificidades do que como a causa do universo, e a única personagem a tratá-lo abertamente enquanto tal e apenas enquanto tal é Filão. Mas agora ele não criticará a falta de definição de Deus, e sim o único ponto concedido até então, a saber, a analogia, que se baseia na imensa semelhança entre o mundo e os produtos de engenho humano. Segundo Filão,

há uma espécie de controvérsia que, pela natureza mesma da linguagem e ideias humanas, está envolta numa ambiguidade 
perpétua que nunca pode, por quaisquer precauções e definições, ser capaz de alcançar uma certeza ou precisão razoáveis. Estas são as controvérsias concernentes ao grau de qualquer qualidade ou circunstância. Os homens podem discutir por toda a eternidade se Aníbal era um grande, um grandíssimo ou um superlativamente grande homem, qual grau de beleza Cleópatra possuía, de qual epíteto Lívio ou Tucídides é digno, sem trazerem a controvérsia a qualquer determinação. (ibidem)

Ora, bem se pode dizer que a semelhança afirmada pelo teísta é grande, grandíssima ou superlativamente grande: não temos um parâmetro fixo para afirmar graus de semelhança, e nem como medi-los ou testar as afirmações que fazemos dele. $\mathrm{O}$ argumento da analogia permanecerá então sempre sem resolução, estando o grau de semelhança afirmado ao gosto do freguês. Para vermos que "a disputa concernente ao teísmo é desta natureza e por conseguinte é meramente verbal, ou talvez, se possível, ainda mais incuravelmente ambígua, ver-se-á com a investigação mais tênue" (ibidem): basta pressionarmos ateus e teístas para ver que ambos dizem o mesmo, mas discordam na intensidade da analogia afirmada:

Pergunto ao teísta se ele não admite que há uma diferença grande, incomensurável porque incompreensível, entre a mente $h u$ mana e a divina - quanto mais pio ele for, mais prontamente assentirá à afirmativa e mais estará disposto a aumentar essa diferença [...]. Em seguida volto-me para o ateu [...] e lhe pergunto se, pela aderência mútua e concórdia aparente de todas as partes do mundo não há um certo grau de analogia entre todas as operações da natureza, em toda situação e em toda era; se o apodrecimento dum nabo [!], a geração dum animal, a estrutura do pensamento humano não são energias que provavelmente mantêm alguma analogia remota entre si, é impossível que ele negue isto [...]. (ibidem) 
Aqui, assim como na nota da Parte XII que não é atribuída a nenhuma personagem, ao invés de querer enfatizar que o ateu cede ao teísta, perguntamos se não seria o caso de enfatizar que o teísta cede ao ateu. Se fosse um grande ponto teológico em que os dois concordassem, de fato faria sentido dizermos que o ateu cede ao teísmo; mas trata-se dum ponto de grande ambiguidade, duma analogia já esvaziada de qualquer sentido religioso ou doutrinário, declarada mesmo ambígua e tênue. (E é difícil "manter o rosto sério" com a imagem sugerida do teísta triunfal forçando o ateu a admitir a semelhança entre um nabo podre e o universo.) Ao cabo, é o teísta que é reduzido ao ateu, assim como o metafísico o fora antes.

Alguns comentadores tentam salvar ao menos o ponto de que há para Filão uma religião verdadeira que não tem nenhuma implicação moral e consiste somente no reconhecimento de que há um designador do universo. Bom, não insistiremos mais nisto de refutar que dá para humeanos assentirem a um designador. Quanto a chamar de religião o simples assentimento a uma proposição sem qualquer influência na vida prática, questionamos apenas se isto não seria um abuso de termos - assim como falar numa doença que não afete a saúde, ou num emprego em que não se receba nada para ficar em casa desocupado.

Mas, pergunta-se, como conciliar toda a crítica de Filão com o final da Parte XII, onde ele recomenda a Pânfilo a proposição de que "ser um cético filosófico é, num homem de letras, o primeiro e mais essencial passo para ser um cristão são, crente" (§33)? Poderíamos especular por alto que talvez ele recomende apenas para que o discípulo de Cleantes, de antemão voltado para o cristianismo e que portanto quererá tornar-se tal cristão, termine por abraçar a posição do próprio Filão; que tratar-se-ia assim apenas de mais uma astúcia da personagem que recomendaria 
uma proposição em que não crê a fim de que um pupilo seja bem orientado. De todo modo, o que sabemos por toda a crítica de Filão, a qual se vale de aparato humeano, é que ele não pode assentir a essa proposição - ou poderia um cristão não crer que Deus é uno ou bom ou onipotente?, ou poderia um cético dar qualquer atributo destes à divindade?

Cabe então notar, primeiro, que nem tudo o que Filão diz é compatível com suas próprias opiniões. Por exemplo, também na Parte XII, quando diz:

sou menos cauteloso neste assunto da religião natural do que em qualquer outro, tanto porque sei que nunca poderei, neste ponto, corromper os princípios de qualquer homem de senso comum, quanto porque ninguém, aposto, a cujos olhos eu pareça um homem de senso comum, jamais confundirá minhas intenções. $(\S 2)$

Mas já sabemos que não há inclinação natural para o teísmo, pois os antigos derivaram a origem do mundo de cópula animal. A seguir, como que confirmando a opinião de Cleantes, Filão diz:

É com prazer que ouço GALENo raciocinar sobre a estrutura do corpo humano. A estrutura, diz ele, desvela mais de 600 músculos diferentes, e quem quer que os considere devidamente verá que em cada um deles a natureza tem que ter ajustado ao menos dez circunstâncias diferentes para lograr o fim a que ela se tinha proposto: figura própria, magnitude justa, disposição certa dos vários fins, posição do todo mais acima e mais abaixo, a inserção devida dos vários nervos, veias e artérias; então, em músculos apenas, mais de 6.000 visões e intenções têm de ter sido formadas e executadas. ( $(3)$

Mas sabemos que isto contraria o que Filão acabara de dizer: que "a natureza age pelos métodos mais simples e escolhe os meios mais próprios para qualquer fim" (\$2), ao invés desse calculo 
de 6.000 visões para os músculos de cada animal. Mais ainda, sabemos que Filão se baseara em todos os Diálogos na economia de causas para fundamentar suas críticas - mais ainda, sabemos que a economia de causas é abraçada pelo próprio Hume. A diferença entre as afirmações que fazem Filão ceder ao teísta e as que o fazem criticar é fundamentalmente esta: as últimas têm embasamento e coesão teóricas; as primeiras, não. $\mathrm{Na}$ verdade, o embasamento teórico se volta todo contra o que essas frases desgarradas dizem.

E o mesmo se dá em proposições assinadas por Hume: enquanto, como vimos, na História natural da religião, ele diz que "todo o plano da natureza evidencia um autor inteligente, e nenhum investigador racional pode, após uma séria reflexão, suspender por um instante sua crença em relação aos primeiros princípios do puro teísmo e da pura religião" (Int.), na Investigação sobre o entendimento humano fala que "quando as pessoas tentam discutir assuntos que ficam inteiramente fora do alcance da capacidade humana, como as que se referem à origem dos mundos [...], podem ficar muito tempo a esgrimir no vazio nas suas infrutíferas disputas" (VIII, i, §1). Frisemos que o teísmo pretende justamente decidir a questão da origem dos mundos: portanto, dizer que sua decisão é vedada ao entendimento humano é de antemão contradizer o teísmo. Isto de limitar o entendimento humano sabemos ser coisa de cético; aquilo de assentir à verdade dum criador inteligente, coisa de teísta. Ambas, frise-se, se opõem. Cremos não precisar lembrar a qual das duas é a filiação declarada de Hume, e tampouco explicar que sua profissão de ceticismo não é ociosa nem isolada em sua obra. Que explica, então, que haja tais frases desgarradas do sistema e a ele contrárias? O esforço do autor para que as obras fossem publicadas sem que ele (ou quem as publicasse em seu lugar quando morto) não corresse riscos de sofrer uma execração pública ou mesmo enfrentar problemas legais, já que no Reino Unido, "quando 
Hume estava escrevendo os Diálogos, a liberdade de discussão estava completa, sujeita apenas a certas limitações convencionadas - que não houvesse apologia de ateísmo e nem desafios diretos a afirmações principais da Fé cristã ${ }^{\prime 113}$. Dentro do conjunto duma obra filosófica feita com a preocupação de escapar à censura, a escolha sã é a de tomar uma frase por legítima somente se ela tiver algum respaldo teórico. Isto faz com que descartemos a credibilidade dessas proposições teístas.

113 KEMP SMITH in Dialogues concerning natural religion, p. 39. (Tradução nossa.) 


\section{Referências}

BOLZANI, R. Acadêmicos versus pirrônicos. São Paulo: Alameda, 2013.

BROCHARD, V. Os céticos gregos. Tradução de Jaimir Conte. São Paulo: Odysseus, 2009

BUTLER, Joseph. A analogia da religião (Introdução). Griot: Revista de filosofia, Amargosa, v. 6, n. 2, p. 20-9, dez. 2012. Tradução de Bruna Frascolla Bloise.

CLAY, J. S. Hesiod's Cosmos. Cambridge: Cambridge University Press, 2003. 209p.

FRASCOLLA, B. Hume: Epistemologia e crítica à religião. 2013. 220 f. Dissertação (Mestrado em Filosofia) - Faculdade de Filosofia e Ciências Humanas, Universidade Federal da Bahia, Salvador. 2013.

MONTEIRO, J. P. Hume e a epistemologia. São Paulo: UNESP; Discurso, 2009. $227 \mathrm{p}$.

MOSSNER, E. C. The Enigma of Hume. Mind, Oxford, v. 45, n. 179, p. 334-49, jul., 1936.

NEWTON, I. An account of the book entituled Commercium epistolicum collinii et aliorum, de analyse promota. Philosophical Transaction of the Royal Society, Londres, n. 342, p. 173-224, jan./fev., 1715.

NEWTON, I. Opticks. Nova Iorque: Prometheus, 2003. 414p.

NEWTON, I. The Principia. Tradução de Andrew Motte, Nova Iorque: Prometheus, 1995. 445p.

PASSMORE, J. Hume's Intentions. 3. ed. Grã-Bretanha: Duckworth, 1980. 180p.

PRICE, J. V. Sceptics in Cicero and Hume. Journal of History of Ideas, Pensilvânia, v. 25, n. 1, p. 97-106, jan./mar. 1964. 
SMITH, N. K. Introduction. In: HUME, D. Dialogues Concerning Natural Religion. 2. ed. Nova Iorque: Macmillan, 1987. 249p.

SMITH, P. J. O ceticismo de Hume. São Paulo: Loyola, 1995. 303p. 


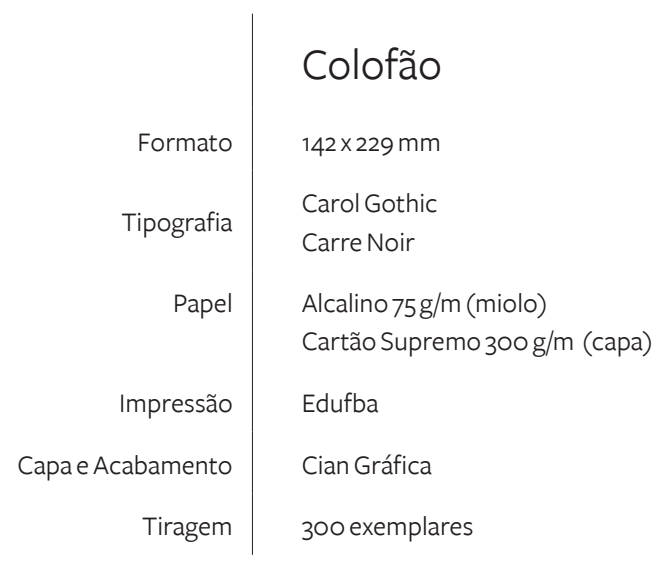

